\title{
The Dalradian rocks of the Highland Border region of Scotland
}

\author{
P.W.G. Tanner, C.W. Thomas, A.L. Harris, D. Gould, B. Harte, J.E. \\ Treagus and D. Stephenson
}

P.W. Geoff Tanner Department of Geographical and Earth Sciences, University of Glasgow, Gregory Building, Lilybank Gardens, Glasgow G12 8QQ.

Christopher W. Thomas British Geological Survey, Murchison House, West Mains Road, Edinburgh EH9 3LA.

Anthony L. Harris Department of Earth, Planetary and Marine Sciences, Cardiff University, Park Place, Cardiff CF10 3YE.

David Gould formerly British Geological Survey, Edinburgh.

Ben Harte School of GeoSciences, University of Edinburgh, West Mains Road, Edinburgh EH9 3 JW.

Jack E. Treagus 15 Raynham Avenue, Didsbury, Manchester M20 6BW; formerly Department of Earth Sciences, University of Manchester.

* David Stephenson British Geological Survey, Murchison House, West Mains Road, Edinburgh EH9 3LA.

dstabgs.ac.uk

$0131650 \quad 0323$

* Corresponding author

Keywords:

Geological Conservation Review

Highland Border region

Dalradian Supergroup

Lithostratigraphy

Structural geology

Metamorphism

\begin{abstract}
The Highland Border region is defined here by the outcrop of the Southern Highland Group that lies north-west of the Highland Boundary Fault and runs from Stonehaven south-west to the Isle of Bute, and thence to the Campbeltown peninsula. The lateNeoproterozoic to early-Ordovician rocks of the Dalradian Supergroup in this region form a stratigraphical and structural entity that encompasses the $>300 \mathrm{~km}$-long surface traces of both the Tay Nappe (D1-D2) and the Highland Border Downbend (D4). The least deformed and metamorphosed Southern Highland Group rocks occur along the south-east margin of the region and are in continuity with the younger, newly recognized Trossachs Group, which has therefore been assigned to the Dalradian Supergroup. The earliest (D1) structures in the Dalradian rocks are dominant close to the Highland Boundary Fault but are successively overprinted northwards by D2, D3 and D4 structures and fabrics, here represented by a series of zones near-parallel to the Highland Boundary. Regional
\end{abstract}


metamorphism increases progressively away from the Highland Boundary Fault and ranges from greenschist to upper amphibolite facies (sillimanite zone). Three fundamental features of deformed and regionally metamorphosed rocks worldwide were first recognized in this area: the 'stretching lineation' by Clough in 1897; the concept of regional metamorphic 'Barrovian zones' by Barrow in 1901; and the 'facing direction' of folds by shackleton in 1958. The Highland Border region has acquired international recognition for research undertaken into the origin and mode of emplacement of the Tay Nappe, one of the largest recumbent folds known worldwide. This structure provides a framework for linking together most of the GCR sites in this paper.

\section{INTRODUCTION}

\section{P.W.G. Tanner and J.E. Treagus}

The Highland Border region is defined here as the outcrop of the Southern Highland Group that is bounded to the north-west by its contact with the outcrop of the Argyll Group, and to the south-east by an ill-defined and much disputed contact with the Cambrian to Ordovician Highland Border Complex (Johnson and Harris, 1967; Tanner, 1995, 1997, 1998b; Tanner and Pringle, 1997; Bluck and Ingham, 1997; Harris et al., 1998; Bluck, 2000; Tanner and Sutherland, 2007). Both the Southern Highland Group and the Highland Border Complex outcrops are truncated to the south-east by a major structural discontinuity, the Highland Boundary Fault.

The Dalradian rocks of this area form a single narrow outcrop, up to $35 \mathrm{~km}$ wide and $280 \mathrm{~km}$ long, extending from Kintyre to Stonehaven (Figure 1). They consist of a rather monotonous pile of metagreywackes, over $5 \mathrm{~km}$ thick, with relatively thin units of slaty pelite that were once quarried for roofing slate at a number of localities such as Arran, Aberfoyle and Dunkeld. Volcaniclastic beds, commonly known as 'green beds', occur in the lower part of the sequence. Despite the uncertainty about its upper boundary, the Southern Highland Group in this outcrop forms a discrete unit in terms of its depositional history, structure, and regional metamorphism. It consists of a series of deep-sea fan turbidites that pass upwards into a passive-margin sequence, the sedimentary edifice being contained within a single major fold structure, the Tay Nappe.

The Tay Nappe is a large, early fold that was flat-lying, or recumbent, following the D2 deformation and was then folded by the Highland Border Downbend (F4) along a line close to, and parallel with, the south-eastern limit of the Highland Border region (Figure 1). The lower, inverted limb of this fold occupies most of the Highland Border region and the main hinge-zone crops out between Arran and Callander. Farther to the north-east, beyond Dunkeld, it is either truncated by the Highland Boundary Fault or buried beneath an unconformable cover of Siluro-Devonian sedimentary and volcanic rocks of the old Red Sandstone Supergroup and hence is not exposed.

Most of the Dalradian rocks are affected by up to four superimposed phases of deformation (D1-D4), the first three of 
which are attributed to the mid-Ordovician Grampian Event of the Caledonian Orogeny and the last possibly to the mid-Silurian Scandian Event. The Grampian deformation was accompanied by regional metamorphism that reached a peak in the upper amphibolite facies (sillimanite zone). Migmatites, arising from partial melting, occur in the highest grade rocks, and the regional metamorphic minerals include chlorite, biotite, garnet, chloritoid, staurolite, kyanite, and sillimanite (see the Glen Esk GCR report). The regional metamorphism reached its peak some $470 \mathrm{Ma}$ ago, at around D2-D3, and it is thought that the growth of the mineral assemblages in each zone occurred during a relatively brief period of 10-15 Ma (Oliver et al., 2000; Baxter et al., 2002).

A further compelling reason for considering this outcrop of the Southern Highland Group as a separate region is that it displays a structural unity throughout its length. This is defined in plan view by: the NE-trending axial traces of the Tay Nappe (D1 and D2) and the Highland Border Downbend (D4) (Figure 1); the line marking the onset in a north-westerly direction of intense D2 reworking of bedding and the S1 fabric; and, less exactly, the traces of the biotite and garnet isograds.

This intensively studied region is now achieving international status as a model for short-lived orogenesis (less than $10 \mathrm{Ma}$ ) in which the unusually rapid rise in temperature of the deforming rock mass probably resulted from advective heat introduced via circulating fluids from contemporaneous intrusions (Atherton and Ghani, 2002; Dewey, 2005). This was aided by the loading and blanketing effects of an ophiolite nappe, which was emplaced over the Dalradian sedimentary rocks early in the Grampian Event (Tanner, 2007; Chew, et al., 2010; Cutts, et al., 2011). Although some of the first radiometric ages from these rocks, especially KAr ages on slaty pelites and on white micas, gave ages of over 500 Ma, these are now considered to be unreliable, and there is no tangible evidence that a late-Neoproterozoic orogeny affected the Dalradian prior to the Grampian Event (cf. Hutton and Alsop, 2004, 2005; and see Tanner, 2005).

Examples of seminal studies carried out in the Highland Border region that have gained international recognition as being unique in their field include:

(i) first use of minor structures in structural interpretation, and the recognition of polyphase deformation (Cowal peninsula; Clough, in Gunn et al., 1897) (Figure 5). This approach is exemplified by the three GCR sites in the south-west (Ardscalpsie Point, Cove Bay to Kilcreggan and Portincaple), and especially by the three GCR sites around Dunkeld (Little Glen Shee, Craig a'Barns and Rotmell) that have been grouped together with this purpose in mind.

(ii) formulation of the concept of zones of metamorphic grade, and the recognition of the Barrovian and Buchan types of metamorphism (Barrow, 1912). The geology of the area in which this work was carried out is described in the Glen Esk GCR site report, which includes illustrations of the key Barrovian mineral assemblages.

(iii) introduction of the concept of structural facing in polyphase terrains to facilitate understanding of the structural evolution of an area, and to demonstrate the existence of a major 
fold, the Tay Nappe (Shackleton, 1958). This theme is central to many of the GCR site reports in this paper and Shackleton's work features particularly strongly in the Duke's Pass GCR site report and in the reports of the three GCR sites around Dunkeld.

The Trossachs area, which includes the Bealach nam Bo and Duke's Pass GCR sites, is now part of the first National Park to be established in Scotland. In the 19th Century it attracted many famous painters, including Constable, Millais and Turner, and the poet Wordsworth. But it is John Ruskin, founder member of the PreRaphaelite movement, who has left us the legacy of the beautiful drawing reproduced in Figure 3. Ruskin was inspired by the form of natural objects and strove to reproduce their every detail; his aim was to encourage his contemporaries to replace pastoral scenes with paintings that depicted 'rocks drawn with such accuracy that the geologist's diagram was no longer necessary' (Greive, 1996).

In this paper, the GCR site reports are arranged as far as is possible in geographical sequence from south-west to north-east and, with the exception of the Glen Esk GCR site report on regional metamorphism, all of them deal specifically with the stratigraphy and structure of the Southern Highland Group. There are no GCR sites on the Campbeltown peninsula or on the Isle of Arran, a total area of some $30 \mathrm{~km}^{2}$, reflecting a lack of detailed studies of the Dalradian rocks in that area.

\subsection{Stratigraphy}

The Southern Highland Group in the Highland Border region consists of a thick sequence of turbidite-facies rocks (now metagreywackes) with interdigitations of slaty pelite, and uncommon chloriteepidote-rich beds known as 'green beds', whose detrital volcaniclastic origin is discussed in detail in the Bealach nam Bo GCR site report (see also Pickett et al., 2006). Major lateral facies changes occur at all levels within a sequence that, apart from the green beds, generally lacks lithostratigraphical marker horizons. Fault-controlled compartments have given rise to local successions that are now seen at different depths of erosion due to kilometre-scale displacements on major faults such as the Loch Tay Fault (Figure 2).

The base of the Southern Highland Group is taken at the top of the Loch Tay Limestone Formation throughout most of the Highland Border region, although to the north-east of the Glen Doll Fault it is taken above locally abundant calcsilicate beds in the dominantly psammitic Tarfside Psammite Formation (Gibbons and Harris, 1994; Stephenson and Gould, 1995).

The top of the Southern Highland Group (Figure 2) has defied definition since the late 19th century and is still the subject of controversy (see the Keltie Water GCR site report; Bluck and Ingham, 1997; Tanner, 1997 for discussion). This is because, despite the sharp contrast between the ubiquitous slaty metamudstones and metagreywackes of the Southern Highland Group and the great variety of rock types, such as serpentinite, black graphitic mudstones and fossiliferous limestones, found in the Highland Border Complex, the boundary between the two units is difficult to define. Clough (in Gunn et al., 1897) concluded that 
at Callander (Keltie Water GCR site) there is a passage or transition between the two sequences, and Cunningham Craig (1904) reported that there is a metamorphic transition in the Loch Lomond area between a 'slate-grit series' and 'schists' to the north.

The problem facing the early surveyors was two fold: which is the younger set of rocks; and where do the 'Highland Schists' end and the Highland Border rocks begin? Amongst the early workers there were two schools of thought: (1) those like Macnair (1908) who, because the bedding or foliation in both sets of rocks throughout most of the zone dips steeply to the north-west, considered that the rocks in the south (now named the 'Highland Border Complex') are older than the 'Highland Schists' (now Dalradian) to the north; and (2) those like Peach (1930) who, persuaded by lithological similarities between the Highland Border Complex rocks and the Arenig-age mudstones in the Southern Uplands of Scotland, considered that they are the younger unit.

This latter interpretation was confirmed by the discovery of poorly preserved Ordovician fossils in the Highland Border Complex, for example in the Aberfoyle Forest (Jehu and Campbell, 1917), followed by the finding of definitive fossil assemblages of Early Cambrian age at Leny Quarry (Pringle, 1940), and of mid-Arenig age at Lime Craig Quarry (Curry et al., 1984) (see the British Cambrian to Ordovician Stratigraphy GCR volume; Rushton et al., 1999). This shifted the focus of the argument to deciding whether or not the two units are in stratigraphical sequence, or whether they are separated by a tectonic break. Resolution of the main problem, that of defining the top of the Dalradian succession, was not furthered by Gregory (1931) who proposed that the 'Dalradian' rocks should be divided into five separate units, with the most southerly of these, the 'Lennoxian', being unconformable on the 'Dalradian' and containing clasts derived from it. No evidence has been published by later workers to support that interpretation.

In the decade that followed the publication by curry et al. (1984), it became generally accepted that the Highland Border Complex is an 'exotic terrane' that docked with the Grampian Terrane in Silurian to Devonian times. This hypothesis was challenged by Tanner (1995), who confirmed the conclusions of Johnson and Harris (1967) and considered that much of the Highland Border Complex is in stratigraphical and structural continuity with the accepted Dalradian sequence. Tanner and Sutherland (2007) then proposed that all of the Highland Border Complex that crops out north-west of the Highland Border Ophiolite should be included in the Dalradian Supergroup and assigned to a new Trossachs Group, which ranges in age up to topmost Tremadocian. Although the tendency in recent years has been to include an increasing proportion of the Highland Border Complex in the Dalradian succession (e.g. BGS 1:50 000 Sheet 38E, Aberfoyle, 2004; Henderson et al., 2010), this topic is still being debated (Bluck, 2010; Tanner and Bluck, 2011). For the purpose of this special issue, the top of the Dalradian succession is taken to be at the southeastern limit of the Keltie Water Grit Formation (see the Keltie Water GCR site report).

The Dalradian outcrop is terminated locally at its south-eastern margin by a faulted or unconformable contact with Silurian, Lower 
Devonian, Upper Devonian, or Lower Carboniferous rocks in the Highland Border region, as seen at the Ardscalpsie Point, Cove Bay to Kilcreggan, and Duke's Pass GCR sites.

Having defined the top and base of the Southern Highland Group, the stratigraphical sequence is now described with reference to the NW-SE-trending serial cross-sections shown in Figure 4. The Loch Tay Limestone, which marks the top of the Argyll Group, occurs in the hinge-zones of the early folds and, together with the Green Beds, provides a marker horizon for correlating between the sections. It clearly shows that, although there is stratigraphical and structural continuity along the whole belt, a marked difference in structural level occurs across the Loch Tay Fault. This fault has a significant downthrow to the east, and rocks now exposed at the surface west of the fault (Figure 4, sections $\mathrm{AA}^{\prime}$ to $\mathrm{CC}^{\prime}$ ) represent a deeper structural level than those to the east.

\subsubsection{West of the Loch Tay Fault}

The oldest exposed rocks of the Southern Highland Group occur both along the north-west margin of the Highland Border region, and close to its south-east margin, within the closure of the downwardfacing Fl Aberfoyle Anticline, in the hinge-zone of the Tay Nappe. These slaty pelitic rocks appear to pass laterally into impersistent volcaniclastic metasedimentary rocks that occur in various places near the base of the Southern Highland Group (Figure 4, sections $A A^{\prime}$ and $C C^{\prime}$ ) and have been correlated with the Loch Avich lavas at the Loch Avich GCR site (Treagus et al., 2013). They are generally referred to semiformally as the Green Beds (e.g. at the Barmore Island and Cove Bay to Kilcreggan GCR sites) (Figure 2), but at the Duke's Pass GCR site, where they are particularly well developed, they define the Loch Katrine Volcaniclastic Formation. The latter is overlain by the Craig Innich Sandstone Formation, a local, laterally discontinuous formation containing beds of microconglomerate up to two metres thick.

The 'slate' formations are represented in the south-east by the Aberfoyle Slate Formation, which is seen in its type area at the Duke's Pass GCR site as black, dark grey, purple, and olive-green slaty metamudstones that are commonly slightly calcareous. These metamudstones appear to be laterally continuous within the Highland Border region but south-west of Aberfoyle there are several such outcrops and their exact correlation with the metamudstones at Luss on the west side of Loch Lomond is not secure. However, the 'Luss Slates' may be traced along strike across several sea lochs to equate with metamudstones in the Dunoon Phyllite Formation at the Cove Bay to Kilcreggan GCR site and on Bute. As the hinge of the Aberfoyle Anticline is contained within the metamudstone outcrop, the rocks on either side of it should young away from the metamudstones, and be stratigraphically equivalent, if not lithologically identical.

The rocks to the north-west of the Aberfoyle Slate/Dunoon Phyllite outcrop have much the same character for over $15 \mathrm{~km}$ across strike, as characterized by the Beinn Bheula Schist Formation seen at the Portincaple GCR site. South-east of the metamudstone unit, on the upper limb of the Tay Nappe, (Figure 2b) the right-way-up St Ninian 
Formation in the south-west (i.e. at the Ardscalpsie Point and Cove Bay to Kilcreggan GCR sites) consists largely of pebbly metagreywackes in beds up to $3 \mathrm{~m}$ thick that commonly show graded bedding. The more-extensive lower part of the St Ninian Formation is the Bullrock Greywacke Member but locally the upper part of the succession contains units of black slaty metamudstone and thin beds of metacarbonate rock and has been referred to by some as the Innellan 'group' (e.g. Roberts, 1966a). On the current BGS 1:50 000 Sheet 29E (Dunoon and Millport, 2008) most of the former Innellan 'Group' is termed the Toward Quay Grit Member of the St Ninian Formation but on the Isle of Bute the highest beds are termed the Ardscalpsie Formation and are assigned to the Trossachs Group.

The predicted correlation of the Bullrock Greywacke with the Beinn Bheula Schist Formation, around the closure of the Aberfoyle Anticline, is problematical (as discussed in the Cove Bay to Kilcreggan GCR site report), for the pebbly and gritty metasandstones of the former contrast with the thinly bedded, chlorite-rich Beinn Bheula metagreywackes. Apart from the facies change, the problem is compounded by the fact that the rocks on the north-west limb are schistose and strongly deformed and rarely preserve way-up structures. In order to clarify this difference, the stratigraphical columns in Figure 2 show the lateral correlations separately for the north and south limbs of the Aberfoyle Anticline.

\subsubsection{East of the Loch Tay Fault}

Along the north-western edge of the Southern Highland Group outcrop, the Loch Tay Limestone is succeeded by the Pitlochry Schist Formation, which includes green beds at several stratigraphical levels (e.g. Treagus, 2000).

On the south-east limb of the Aberfoyle Anticline, the Bullrock Greywacke Member of the St Ninian Formnation passes north-east along strike into the Ben Ledi Grit Formation, as seen at the Duke's Pass GCR site (Figure 2). The Keltie Water GCR site is particularly important as the section demonstrates both structural and stratigraphical continuity between strata of the Ben Ledi Grit Formation that are indisputably in the upper part of the Southern Highland Group and strata of the Keltie Water Grit Formation that include the fossiliferous Leny Limestone. Hence, not only did Dalradian sedimentation extend into the Early Cambrian, but its principal phases of deformation must all have occurred in postEarly Cambrian time, two crucial age relationships that until recently had been widely disputed.

Farther north-east, the exact stratigraphical affinity of the Birnam Slate, the Birnam Grit and the younger Dunkeld Grit Formation, described in the Little Glen Shee and Craig a' Barns GCR site reports, is uncertain. They were at one time correlated with the Aberfoyle Slates and the Ben Ledi Grits, but more-recent mapping has shown that they occur at a higher level in the Southern Highland Group succession (Figure 4, section DD'). The stratigraphical status of the psammites and semipelites at the 
Rotmell GCR site is also not clear, but they could be a lateral equivalent of the Pitlochry Schist Formation.

North-east from the Dunkeld area, the general stratigraphical relationship of a lower, more-pelitic metagreywacke sequence passing south-eastwards into an upper, more-psammitic metagreywacke sequence persists to the coast north of Stonehaven (Anderson, 1942). The more-pelitic facies forms an outcrop continuous with the Pitlochry Schist and contains similar lithologies, dominated by garnet-mica schists but passing into slates or sillimanite gneisses depending upon metamorphic grade. In the Glen Clova area this basal unit has been termed the Longshank Gneiss Formation. This unit shows a marked facies change from dominantly pelitic in the south-west to dominantly psammitic in the north-east and is characterized by strongly magnetic beds throughout (Chinner, 1960). The younger, graded metagreywackes and schistose psammites of the Rottal Schist Formation are continuous with the Ben Ledi Grit to the south-west. Green beds are abundant between Kirkmichael and Glen Clova but are notably absent north-east from Glen Clova.

An extensive right-way-up sequence that crops out around the Glen Esk GCR site was assigned by Harte (1979) to a separate Tarfside Nappe (see below). The sequence consists of an intimate metagreywacke association of pelites, semipelites and psammites typical of the Southern Highland Group. A lower unit, the Glen Effock Schist Formation, passes upwards into the Glen Lethnot Grit Formation, characterized by beds of pebbly psammite, and hence a broad correlation is suggested with the Pitlochry Schists and Ben Ledi Grit of the Tay Nappe. The outcrop of the Glen Lethnot Grit can be traced to the coast around the Garron Point to Muchalls GCR site, where the sequence is once again upside down, as in the Tay Nappe.

\subsection{Structure}

Aspects of particular structural interest in the Highland Border region are the geometry and mode of formation of two of the largest folds in the British Isles, the Tay Nappe and the Highland Border Downbend, and the intriguing geometrical relationship between the D1 and D2 structures as expressed in the splendid development of superimposed, spaced cleavages in the metasandstones. The latter are matched only in the UK by those at Trearddur Bay, Holy Island, Isle of Anglesey. The huge monoclinal downbend divides the region into the Flat Belt to the north-west and the Highland Border steep Belt to the south-east (Figures 1 and 4). It folds the originally recumbent or flat-lying Tay Nappe and brings the fold closure down to ground level just north of the Highland Boundary Fault, so exposing at the surface part of the upper limb of the nappe (Figure 4).

Over almost the whole outcrop of the Flat Belt, the level of erosion lies in the lower, inverted limb of the Tay Nappe. However, in a wide area around the Glen Esk GCR site a broad late antiform, known as the Tarfside Culmination, exposes a sequence of non-inverted strata, which Harte (1979) assigned to a separate Tarfside Nappe and interpreted as a major recumbent structure below the Tay Nappe. According to Harte the axial zone of the fold 
separating the two nappes has been replaced by a slide, the Glen Mark Slide. However, the structural relationships are not clear and the distribution of units could also be explained in other ways, for example by invoking later large-scale tight folding of the Tay Nappe on gently dipping axial planes. Farther to the north-east (around the Garron Point to Muchalls GCR site), the structural relationships revert to those seen in the Tay Nappe to the south-west. The flat-lying sequence is inverted and, southeast of a marked downbend, it passes into a steep zone with downward-facing D1 structures (Booth, 1984; Harte et. al., 1987) (Figure 33). The relationships of these major structures to the Tarfside Nappe, or indeed to the main Tay Nappe, are not clear.

\subsubsection{The Highland Border Downbend}

The regional significance of the Highland Border Downbend was recognized by Clough (in Gunn et al., 1897) who noted that it folds an earlier foliation and stretching lineation, and is associated with a crenulation (strain-slip) cleavage. On the Cowal peninsula, it is an open structure with the south-eastern limb dipping southeast at less than $30^{\circ}$. As it is traced north-east, this limb becomes vertical between Loch Lomond and Aberfoyle (Figure 4,

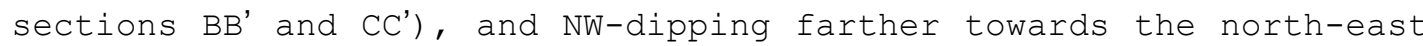
(sections EE' to GG'). Thus, the beds on the south-eastern side of the Tay Nappe axial plane are right-way-up in Cowal and become inverted to the north-east. This relationship has a direct bearing upon the earlier debate as to whether the 'Highland Schists' are older or younger than the Highland Border Complex, and it is a sobering thought that one of the earliest workers in the field made the most prescient observation of all: Nicol (1863) stated that the rocks in question on Bute dip south and are right-way-up, and in the Aberfoyle area dip north, and are inverted. North-east of Birnam, the Highland Border Downbend approaches close to the line of the Highland Boundary Fault and/or the margin of the unconformable Lower Devonian sequence, and its south-eastern limb is reduced to a width of less than $2 \mathrm{~km}$ (Figure 1).

The Portincaple, Craig a'Barns, and Garron Point to Muchalls GCR sites each show different features of this structure. At Portincaple, minor $F 3$ folds on all scales up to several metres in wavelength are clearly folded around the hinge zone of the major downbend structure, and are cut by a sporadically developed, steeply dipping, S4 crenulation cleavage (Figure 12). It is significant that evidence for the presence of all four deformation phases can be seen on a single rock face at this locality, leaving no doubt as to the nature of each and of the relationship between them. At the Craig a'Barns and Garron Point to Muchalls GCR sites, the D3 deformation is absent and step-like minor F4 folds related to the downbend hinge deform the familiar spaced S2 microlithons. At the Craig a'Barns GCR site, the Highland Border Downbend gives rise to the steep Belt of downward-facing Fl folds seen in the Little Glen Shee GCR site. Elsewhere, uncommon minor F4 warps, up to a few metres across, are seen as far south of the downbend as the Cove Bay to Kilcreggan and Ardscalpsie Point GCR sites. 


\subsubsection{The Tay Nappe hinge-zone}

The hinge-zone of the Tay Nappe consists of the Aberfoyle Anticline and a variable number of satellite folds. The hinge was first described as a normal, upward-facing anticline closing to the south-east (Henderson, 1938; Anderson, 1947a). However, although these authors had used sedimentary way-up structures to identify the structure as an anticline, they had incorrectly interpreted it as closing upwards, a mistake easily made where the major fold is tight to isoclinal. Another approach was needed, and it was Shackleton (1958) who, using the concept of facing direction (as applied to fold structures and cleavages, see Stephenson et al., 2013a) that he had developed in the course of his work in the Highland Border region, demonstrated that the Aberfoyle Anticline is a downward-facing, or synformal, anticline. He correctly deduced that a large part of the South-west Grampian Highlands consists of rocks that are upside down because they belong to the lower limb of an originally recumbent, south-facing nappe-like structure, named the Tay Nappe.

The closure of the Tay Nappe has been traced, as a single fold from the Isle of Bute to Luss on the west side of Loch Lomond (Roberts, 1967) (Figures 1 and 4, sections $\mathrm{AA}^{\prime}$ and $\mathrm{BB}^{\prime}$ ). It passes through the Cove Bay to Kilcreggan GCR site where it is located within the outcrop of the Dunoon Phyllites but unfortunately it is not exposed on the coast due to faulting. East of Loch Lomond, the fold closure becomes more complex and can be resolved into three, well-defined major folds, the Ben Vane Anticline, the Ben Ledi Syncline and the Aberfoyle Anticline (Mendum and Fettes, 1985) (Figures 4 and 13). The Keltie water GCR site lies on the nowinverted upper limb of this tripartite structure. Farther to the north-east, the Duke's Pass, Craig a'Barns, and Little Glen shee sites all lie to the north-west of the predicted position of the Tay Nappe closure, which in these localities is either faulted-out or buried beneath an unconformable cover of Lower Old Red Sandstone sedimentary rocks (Figure 1). Although downward-facing structures inferred to be on the north-western side of the Tay Nappe hinge zone can be traced to the east coast at the Garron Point to Muchalls GCR site, the main hinge is not seen north-east of Little Glen Shee.

\subsubsection{Sequential development of the structural fabrics, and their interpretation}

The structural development of this region is most clearly understood by considering the sequential development of minor structures such as cleavages along a traverse from the higher structural levels of the Tay Nappe (now seen adjacent to the Highland Boundary Fault) to the deeper levels (as seen at the Highland Border Downbend).

In a zone up to $10 \mathrm{~km}$ wide adjoining, and parallel with, the Highland Boundary Fault, the Dalradian rocks are least deformed, preserve abundant sedimentary structures, and carry only a single (S1) cleavage. Farther to the north-west they are affected progressively by three further, superimposed, phases of deformation 
(D2, D3 and D4), accompanied by regional metamorphism that reached a peak in the upper amphibolite facies (sillimanite zone) around D2-D3.

The upper, right-way-up limb of the Tay Nappe is excellently exposed at the Ardscalpsie Point GCR site where a single, centimetre-spaced, anastomosing s1 pressure-solution cleavage cuts across the bedding at a low angle and is unaffected by later deformation (Figure 7). The S1 cleavage is seen to form extreme cleavage fans in gritty metasandstones at the Little Glen shee GCR site, where the full geometry of the Dl phase may be examined (Figure 19). Sedimentary and tectonic structures that proxy for those anticipated in the very hinge of the nappe may be readily seen at Camsail Bay, a few kilometres from the Cove Bay to Kilcreggan GCR site (see Tanner, 1992).

The S2 fabric and associated minor structures is first seen a few kilometres north-west of the Highland Boundary Fault and within a short distance becomes the dominant structure. It forms a set of penetrative pressure-solution-controlled microlithons. The S1 spaced cleavage was reworked during D2 and is commonly preserved within the new microlithons as sigmoidally curved traces with a distinctive appearance, unique in the structural history of the Dalradian rocks. An example is shown in the Cove Bay to Kilcreggan GCR site report (Figure 10). Minor structures of this type can be recognized far to the north within the Flat Belt and are used as event markers (see the Portincaple GCR site report, Figure 12). They were recognized in the Cowal peninsula by Clough (in Gunn et al., 1897), who called them 'strain bands' (Figure 5). This zone of intense D2 deformation can be recognized across the full width of the region (Figure 1 ) and the morphology of the structures has been described in detail from Birnam by Harris et al. (1976) and from Stonehaven in the Garron Point to Muchalls GCR site report, in this paper.

A contentious issue is the interpretation of the shear sense given by the deformed early (S1) cleavage stripes within the S2 microlithons. A majority of authors favour top-to-the-SE shear displacement, with others equally convinced that top-to-the-NW displacement has taken place. In this paper, the Rotmell GCR site report describes the typical F2 fold style in this part of the Flat Belt, and its evolution by SE-directed simple shear, whereas the author of the Bealach nam Bo and Duke's PasS GCR site reports favours the alternative interpretation.

These views have led to fundamentally different interpretations of the tectonic regime responsible for the emplacement of the Tay Nappe and related structures. The emplacement is generally considered to have been coeval with the formation of the first folds, although some workers have questioned this. Mendum and Fettes (1985) and Mendum and Thomas (1997) considered that F1 folds must have been recumbent and hence that the Tay Nappe was emplaced during D1, with subsequent NW-directed simple-shear during D2. However, Harris et al. (1976) and Harris and Bradbury (1977) considered that the F1 folds were initially upright and were subsequently modified by SE-directed, mainly simple-shear within a continuous phase of deformation involving both D1 and D2. Their model was modified by Krabbendam et al. (1997) who proposed that 
only the lower levels of upright Fl folds were affected by a crustal-scale shear-zone during D2, to produce SE-facing folds with dominant inverted limbs that constitute the Flat Belt; the upper levels of the F1 folds, unaffected by D2 shearing, were subsequently brought down by the Highland Border Downbend to produce the downward-facing steep Belt.

During D3, the rocks were affected locally, for example around Loch Lomond and at the Portincaple GCR site (but not at the Craig a'Barns GCR site farther to the north-east), by minor folding and very restricted cleavage development, but no new major folds were formed.

The final event, during D4, was the bending down of the closure of the Tay Nappe close to, and parallel with, the Highland Boundary Fault by the Highland Border Downbend. This brought the hinge-zone and a small part of the upper limb of the Tay Nappe structure down to the present erosion level. The formation of D4 structures is considered by some to be related to and also to post-date a phase of crustal extension during uplift. The initial monoformal form of the Highland Border Downbend is considered to be due to the draping of Dalradian strata over a basement step (Harte et al., 1984). Subsequent compression resulted in tightening of the downbend, which became a focus for smaller-scale F4 folds.

\subsection{Regional Metamorphism}

Work in Glen Esk led Barrow (1912) to develop the concept of zones of metamorphic grade, and to recognize two main types of metamorphism in the Grampian Highlands, Barrovian and Buchan (see Stephenson et al., 2013a). Modern studies in the Highland Border region have shown that there, the regional metamorphism reached a peak during the interval D2-D3, resulting in a series of Barrovian zones characterized by the index minerals chlorite, biotite, garnet, staurolite, kyanite and sillimanite (see the Glen Esk GCR site report). The isograds are widely spaced in the west and become very closely spaced towards the north-east (Stephenson et al., 2013a, fig. 12). The lowest grade rocks are at greenschist facies and retain detrital white mica and biotite, whereas the highest grade rocks develop sillimanite and are associated with the formation of migmatite by partial melting. All of the GCR sites in the south-west of the region are in greenschist-facies rocks. Garnet, wrapped by the S2 fabric, is prominent in the schists of the Flat Belt at the Rotmell GCR site and is visible as pinheadsize crystals, with biotite, in the phyllites at the Craig a' Barns GCR site. The green beds of the Bealach nam Bo GCR site, within the Steep Belt of the Highland Border Downbend, are rich in chlorite and epidote that are associated with the s2 cleavage. Elsewhere along the steep Belt the pelites are characteristically chlorite-white mica-bearing slates with an S1 cleavage, as seen in the Keltie Water, Duke's Pass and Little Glen Shee GCR sites.

The close spacing of the regional metamorphic isograds in the north-east has been a cause for some speculation in the past but recent work suggests that advective heating by fluids from contemporaneous intrusions is the probable culprit, assisted by ductile shearing during D2 (Phillips and Auton, 1997). It has been 
demonstrated that peak metamorphic temperatures reached throughout these zones were synchronous to within 2 million years (Baxter et al., 2002), the implication being that the deformation process was also rapid.

\section{ARDSCALPSIE POINT (NS 043 580-NS 045 576)}

\section{P.W.G. Tanner}

\subsection{Introduction}

The Ardscalpsie Point GCR site is situated on the west coast of the Isle of Bute, just to the north of Scalpsie Bay. It consists of a narrow rock platform backed by a steep rock face that forms an almost straight, $400 \mathrm{~m}$-long, section north-west of Ardscalpsie Point (Figure 6). The immediate hinterland, which consists of a raised beach backed by an ancient sea cliff, also provides some excellent exposures.

The metasedimentary rocks exposed in this section are some of the youngest in the Southern Highland Group. They were formerly assigned to the Bullrock Greywacke (sensu Clough, in Gunn et al., 1897) and have also been referred to as the 'Lower Leny Grits' (Anderson, 1947a) and the Innellan 'Group'. They are now assigned to the Toward Quay Grit Member of the St Ninian Formation, which overlies the Bullrock Greywacke Member stratigraphically (i.e. on the BGS 1:50 000 Sheet 29E, Dunoon and Millport, 2008). Immediately east of the GCR site, the Toward Quay Grit Member is overlain by the Ardscalpsie Formation, which is assigned to the Trossachs Group. The GCR site lies well south of the outcrop of the Dunoon Phyllite Formation, which contains the closure of the Tay Nappe (see the Cove Bay to Kilcreggan site report), and has a splay of the Highland Boundary Fault as its southern limit.

This GCR site is of national importance as it provides a unique opportunity to examine a virtually continuous, and clean, coastal section across part of the top limb of the Tay Nappe. The closure of the Tay Nappe can be traced across Scotland but the upper limb of the structure is seldom well exposed. It is seen, for example, to the north-east of this site between Toward and Dunan on the Dunoon peninsula (where it is named the Aberfoyle Anticline: Roberts, 1974) and at the Cove Bay-to Kilcreggan GCR site, but is not as readily studied as at Ardscalpsie Point. Here, the inland exposures, deeply etched by weathering due to their slightly calcareous nature, complement those on the coast and reveal in detail the relationship between the spaced S1 cleavage and the bedding (Figure 7). The contact between the uppermost Dalradian and the much younger, Devonian to Lower Carboniferous strata, seldom seen in the $250 \mathrm{~km}$ between Arran and Stonehaven, is well exposed at the south-east end of the rock platform.

Surprisingly, considering the pioneering work carried out in the neighbouring Cowal peninsula, no details of the Dalradian rocks were given in the Geological Survey memoir covering this part of Bute (Gunn et al. 1903). It was left to McCallien (1938) to 
provide the first general account of the Dalradian of Bute. Anderson (1947a) published a more-detailed account and map of Scalpsie Bay, and concluded, from the dip of the beds combined with way-up evidence, that the Dunoon Phyllites farther north on Bute lie in the core of a 'normal' (i.e. upward-facing) anticline. Conversely, Shackleton (1958) suggested that the Tay Nappe structure is probably a downward-facing anticline, based on an admittedly small number of observations of the geometrical relationship of bedding to cleavage, combined with way-up evidence. The only detailed, modern study of this section was by Simpson and Wedden (1974) who confirmed Shackleton's interpretation, and recorded the three-dimensional relationship of the L1 stretching lineation to the local fold hinges in these rocks.

\subsection{Description}

The coastal section trends at about $60^{\circ}$ to the general strike of the beds, and is excellent for cross-section construction (Figure 8). The only drawback is that, despite almost continuous rock exposure above the high-tide mark, many of the rock surfaces in the intertidal zone, which would normally yield the finer detail, are completely covered with a dense mat of barnacle and algal growth.

The rocks consist of beds of grey-green metagreywacke, generally 1-2 $\mathrm{m}$ thick in the northern part of the section, but reaching $3 \mathrm{~m}$ thick at the southern end. They are separated by thin layers of metasiltstone and/or slaty metamudstone (generally less than $10 \mathrm{~cm}$ thick), or form amalgamated units. The metagreywackes, formerly referred to as 'grits', are fine to coarse grained, and many of the beds show normal grading.

Over thirty examples of graded bedding have been recorded from the section shown in Figure 8 and, as previously reported by McCallien (1938), they show younging to the south-east. Beds are generally right-way-up throughout the section, only becoming overturned on the middle limbs of mesoscopic F1 folds (Figure 8, localities a and b). As a result of the bonding effect of penetrative deformation and cleavage development, the bottoms of beds are very rarely exposed. However, flame structures are seen on the bases of a few beds, and cross-lamination (showing younging to the south-east) is seen in the uppermost, finer grained parts of some beds; Simpson and Wedden (1974, plate 1a) illustrate an example from $450 \mathrm{~m}$ north of the GCR site.

Thin beds of metamudstone and/or metasiltstone occur commonly between the metagreywacke beds in the northern half of the section, whereas thick, amalgamated beds of metagreywacke with no intervening mudrock predominate in the younger rocks to the south. The metamudstone occurs in several guises: as grey-green slaty metamudstone with 1-5 mm-thick bands of black metamudstone; as grey slaty metamudstone with centimetre-scale green bands; and as purplish grey, slaty metamudstone. The latter variety is more common at the southern end of the section.

The matrix of the metagreywackes consists of detrital grains of quartz, feldspar, and muscovite, accompanied by flakes of chlorite and white mica, which grew during the regional metamorphism (Simpson and Wedden, 1974). The granule- to medium-pebble-sized 
clasts found at the bases of graded beds are mainly of quartz, with pink feldspar being common in some beds. Rip-up slabs and angular fragments of dark mudstone, a few centimetres long, occur in a number of the beds.

The beds forming the long limbs of the F1 minor folds are rightway-up, and represent the regional orientation of the upper limb of the 'Tay Nappe'. They dip consistently to the south-east at about $60^{\circ}$, at a steeper angle than the first cleavage (S1; dip $42^{\circ} \mathrm{SE}$ ) throughout the section (Figures 6, 7 and 8). An L1 stretching lineation, plunging at $33^{\circ}$ to the east-south-east, is present as a silky striation on slaty-cleavage surfaces, mainly in the northern part of the section (Simpson and Wedden, 1974).

The penetrative slaty cleavage (S1) developed in the metamudstones is fanned in mesoscopic fold closures and is continuous, via cleavage refraction, with the centimetre-scale micolithons making up the spaced cleavage that affects most of the metasiltstones and metagreywackes (Figure 7b). This spaced cleavage is even seen in some of the 2-3 m-thick metagreywacke beds. Evidence of later ductile deformation is given by a few late, open structures that fold the main cleavage (Figure 8, localities $c, d$ and e), and by an unrelated, gently dipping, crenulation cleavage that occurs locally. Faults with varying orientations occur at regular intervals throughout the section, becoming more significant and marked by massive quartz veins or fault-breccia up to a metre thick, as the Highland Boundary Fault is approached.

The faulted relationship between the Dalradian rocks and red sandstones of the Lower Carboniferous, Kinesswood Formation is fully exposed at beach level in the intertidal zone at locality $f$ on Figure 8. It is marked by a zone of brecciated Dalradian rock up to $14 \mathrm{~m}$ thick, south-east of which major rectilinear fractures separate the Dalradian from the Carboniferous rocks. A $45 \mathrm{~cm}-$ thick, deeply weathered, dyke runs parallel to the fault zone (Hill and Buist, 1994). Reddening of the Dalradian rocks along joints and fractures at this locality suggests that the Old Red Sandstonefacies Carboniferous rocks once lay unconformably on the Dalradian north of the branch of the Highland Boundary Fault, prior the final displacement on the fault.

The Dalradian rocks are weakly metamorphosed, and occur within the chlorite zone of regional metamorphism; detrital white mica is still present in the mineral assemblage, but is accompanied by a felt of smaller, aligned, white mica crystals making up the si fabric.

\subsection{Interpretation}

The St Ninian Formation, and in particular the Bullrock Greywacke Member, have been correlated with similar pebbly metagreywackes found south of the Dunoon Phyllite Formation on the Toward peninsula, Rosneath peninsula (Tanner, 1992; Cove Bay to Kilcreggan GCR site), and west of Loch Lomond, as well as north of the putative Highland Border Complex at North Glen Sannox, Isle of Arran. At all of these localities the Bullrock Greywacke is rightway-up and dips to the south-east on the upper limb of the Tay Nappe. 
At the Ardscalpsie Point GCR site, right-way-up beds dip consistently to the south-east at a steeper angle than the first cleavage (S1) (mean difference $=19^{\circ}$; Figures 6 and 8). This agrees with the minor fold vergence and confirms that the D1 facing direction is down-to-south, and that the 'Tay Nappe' here is a synformal or downward-facing anticline (Shackleton, 1958; Simpson and Wedden, 1974).

Stretching lineations were first described from Dalradian rocks by Clough (in Gunn et al., 1897), from the Cowal peninsula to the north-east of the Isle of Bute. When plotted on an equal area stereographic projection, the Fl fold hinges and intersection lineations from this GCR site are seen to be dispersed along a great circle that contains the mean orientation of the stretching lineation. This result is consistent with the curvilinear nature of some minor folds observed in the field and indicates that a considerable rotation of fold hinges towards the stretching direction (X) has taken place (see the Strone Point and Glen Orchy GCR site reports in Tanner et al., 2013a and Treagus et al., 2013 respectively).

Late warps of the bedding and early cleavage have the step-like geometry characteristic of minor structures congruous with the F4 Highland Border Downbend (see the Portincaple GCR site).

\subsection{Conclusions}

The Tay Nappe is one of the largest fold structures in Scotland. It was excised south-east of the Highlands by movement on the Highland Boundary Fault, leaving the upper limb of the Nappe exposed only in a relatively narrow SW-NE-trending outcrop across Scotland. The importance of the Ardscalpsie Point GCR site lies in the fact that it is probably the best place for studying in detail this limb of the structure, to check whether the field relationships accord with the proposed structural model for the nappe (for details of the evolution of the Tay Nappe, see the Cove Bay to Kilcreggan GCR site report).

At this site, the Dalradian rocks belong to the st Ninian Formation, a thick unit of pebbly metagreywackes and thin beds of slaty metamudstone, which was deposited from turbidity flows in a submarine fan environment. It is amongst the youngest of the Dalradian formations, and occupies a position close to the top of the Southern Highland Group. Sedimentary structures, especially graded bedding, and bedding-cleavage relationships can be very clearly seen in these rocks on the $400 \mathrm{~m}$-long coastal section adjacent to Ardscalpsie Point. The combination of undoubted, and plentiful, way-up evidence, with structural data, provides a very clear demonstration that the St Ninian Formation lies on the upper limb of a major F1 fold, the 'Tay Nappe', that closes downwards and yet has the older rocks in its core. It is a downward-facing, or synformal, anticline, as envisaged by Shackleton (1958), from preliminary observations at Ardscalpsie. This fold, originally flat-lying, was rotated into its present position by folding on the Highland Border Downbend (see the Portincaple GCR site report).

In addition, this GCR site is also excellent for studying the development of spaced cleavage in quartz-rich metasedimentary 
rocks, and is one of the few places where a branch of the Highland Boundary Fault, the major fault bounding the Dalradian outcrop on its south-east side, is fully exposed. In this part of Bute, the Highland Boundary Fault brings Dalradian rocks against Lower Carboniferous rocks: a related fault-zone is fully exposed $600 \mathrm{~m}$ north-west of Ardscalpsie Point and is marked by a zone of brecciated Dalradian rock up to $14 \mathrm{~m}$ wide, and by major rectilinear fractures, which bring the Dalradian and Carboniferous rocks into direct, knife-sharp contact. Evidence from this locality that the Carboniferous rocks once lay unconformably on the Dalradian rocks immediately north of the Highland Boundary Fault suggests that the post Early Carboniferous displacement on the fault branch at Ardscalpsie might have been relatively small.

\section{COVE BAY TO KILCREGGAN (NS 215 836-NS 242804 )}

\section{P.W.G. Tanner}

\subsection{Introduction}

The Cove Bay to Kilcreggan GCR site consists of a $5 \mathrm{~km}$-long strip of coastal exposure, interrupted only by a few pebble beaches, that runs between Knockderry Castle and Kilcreggan Pier on the west side of the Rosneath peninsula (Figure 9). The site is of national importance as it provides the only well-exposed coast section across the putative closure of the Tay Nappe, one of the largest folds in the British Isles. Plentiful minor structures document the development and present-day geometry of this major fold. There is undisputed evidence for four deformational episodes (D1-D4) in the Daladian rocks farther north (see the Portincaple GCR site report), but only D1 and D2 are fully developed at this site. However, a major feature here is the manner in which the D2 deformation, that responsible for the southward propagation of the Tay Nappe (Harris et al., 1976), increases in intensity northwards (downwards in the originally near-horizontal nappe), overprints, and finally destroys most field evidence for the prior existence of the D1 structures.

The sequence of Southern Highland Group rocks within this GCR site formed the original upper limb of the Tay Nappe and occupies a structural setting comparable to that of the Ardscalpsie Point GCR site. It consists mainly of right-way-up turbidite beds of the Bullrock Greywacke Member of the St Ninian Formation, which dip to the south-east and lie both stratigraphically and structurally above the Dunoon Phyllite Formation. This formation in turn overlies inverted strata of the Beinn Bheula Schist Formation. The simplest geological interpretation of these relationships is that the Bullrock Greywacke is the lateral stratigraphical equivalent of the Beinn Bheula Schists, and that these two units represent the two limbs of a downward-facing anticline, the Tay Nappe, which has the Dunoon Phyllites in its core (Shackleton, 1958; Roberts, 1974). 
All of the rocks have been affected by greenschist-facies regional metamorphism. White mica-chlorite-bearing assemblages are ubiquitous and give many of the rocks a greenish tinge.

Although the first published map of the Rosneath peninsula was produced by the Geological Survey in 1878, it was not accompanied by a sheet explanation or memoir. The first account of the geology was by Roberts (1966a), who concentrated mainly on analysing the depositional environment of each stratigraphical unit. This work was followed by the publication of two field guides that described the salient features of several localities within this GCR site (Roberts, 1977b; Tanner, 1992). The geology of the peninsula was also described succinctly by Henderson (in Paterson et al., 1990) in the memoir to accompany the BGS 1:50 000 sheet 30W/29E (Greenock, 1990).

\subsection{Description}

The Bullrock Greywacke consists of gritty and pebbly feldspathic metagreywacke, interbedded with some finer-grained metagreywackes and metasiltstones, and some layers of black slaty metamudstone. The pebbles are mainly of quartz and feldspar. Normal graded bedding, confirmed in some cases by an accompanying erosional base to the bed, or the presence in the same bed of bottom structures, trough cross-bedding or channel infills, is seen at a number of places. Sets of finely spaced cross-laminae are present in the silty tops of a few turbidite beds. However, many of the beds are apparently homogeneous or show evidence of amalgamation. Calcareous concretions of diagenetic origin are common locally. They occur as bedding-parallel lenses and pods up to a few decimetres thick and reaching several metres in length, and as podshaped bodies oblique to bedding. In each case, bedding laminations preserved in the calcareous body are continuous with those in the host greywacke (Tanner, 1992).

Due to faulting, combined with a $200 \mathrm{~m}$ gap in exposure, the contact between the Bullrock Greywacke and the Dunoon Phyllites is not seen on the coast, but evidence from outwith the area in Aldownick Glen (NS 270 850) shows that it is a normal transitional contact (Paterson et al., 1990).

The Dunoon Phyllite Formation consists mainly of black, purple, grey, and olive-green slaty and phyllitic metamudstones, with some beds of gritty metagreywacke, and of finer-grained metagreywacke and metasiltstone. Rare beds of pebbly metagreywacke up to $2 \mathrm{~m}$ thick are also present. Thin lenses and pods of metacarbonate rock occur in the black, phyllitic, graphitic metamudstones. They weather to a dull brown colour and are probably dolomitic in composition. The un-named bed of metagreywacke within the Dunoon Phyllites, exposed on the coast at Barons Point (Figure 9), appears to be in normal stratigraphical contact with the metamudstones to either side of it. There is sparse evidence of way-up from chanelling and cross-lamination in most of the coastal outcrop of the Dunoon Phylites, but the northern part appears to young towards the Beinn Bhuela Schists.

The Beinn Bheula Schist Formation consists of generally wellbedded grey-green metagreywacke, less feldspathic than the Bullrock 
Greywacke, with bands of phyllitic metamudstone and metasiltstone, and uncommon pods of brown-weathering metacarbonate rock. Based on the evidence of sporadic graded bedding and cross-lamination, that part of the sequence exposed south of Knockderry Castle is inverted. The formation includes an 18 m-thick unit of metabasaltic sheets and (?) tuffaceous rocks just to the south of Knockderry Castle (Figure 9) which resemble the green beds of the Loch Lomond area. The contact between the Beinn Bheula Schists and the Dunoon Phyllites is well exposed at NS 220828 and is transitional over more than $20 \mathrm{~m}$. Way-up structures show clearly that the structurally overlying Dunoon Phyllite is the older formation and that both formations young to the north close to their mutual contact.

The structures seen at this GCR site are almost entirely due to the first two deformations, D1 and D2. The S1 cleavage is seen as a centimetre-spaced set of anastomosing microlithons in the gritty rocks; a shape fabric (deformed grit particles) in the finer grained metagreywackes; or a slaty cleavage in the metamudstones. No structures or fabrics related to D3 have been detected. The D4 deformation is very localized and is expressed as NNW-verging, step-like folds, associated with a steep to vertical, millimetrespaced crenulation cleavage that folds S1 and S2.

Three major folds of D1 age occur in the Bullrock Greywacke west and north of Kilcreggan Pier, but their hinge-zones are poorly exposed. However, one of the closures is well exposed along strike at Creag na Goibhre, Camsail Bay, north-east of Kilcreggan (NS 262 822) (Figure 9), and provides an analogue for the closure of the Tay Nappe itself (Tanner, 1992). Structural analysis of the orientations of bedding, S1 cleavage (axial-planar to millimetrescale minor folds and warps), bedding/cleavage intersection lineations, and minor fold hinges show that this fold is a synform with a near-vertical axial plane and a fold axis plunging at less than $10^{\circ}$ to the south-west. Way-up evidence from graded bedding and cross-lamination shows that it is a downward-facing anticline.

D1 structures in the south of the area are in their pristine state, unaffected by later deformation, but north of a line drawn approximately through the Cove Burgh Hall a few hundred yards south-east of Barons Point, the early cleavage can be seen in the field to have been affected by the development of a later spaced cleavage (S2). From this point northwards, the D2 deformation takes over and $\mathrm{S} 2$ rapidly becomes dominant. It is the main, and in some places only, planar structure in the Ben Bheula Schists in the northern half the area, where the sedimentary structures are progressively destroyed; in places only the coarser grained, granule to pebbly metagreywackes and calcareous concretions and layers preserve evidence of bedding surfaces.

D2 microlithons developed in the coarser metagreywackes have centimetre-scale spacing, and in homogeneous gritty metagreywackes, the anastomosing microlithons very closely resemble those of undoubted D1 age seen farther south. The difference is that further inspection usually reveals relics of the earlier spaced cleavage within the D2 microlithons, a striking example of which is shown in Figure 10. The S2 fabric in metamudstones is subtle; in the field, it appears to be a slaty cleavage (S1), but under the 
microscope it is a very closely spaced crenulation cleavage that has clearly deformed an earlier fabric (Tanner, 1992).

F2 minor folds are rare; they fold an earlier cleavage and have hinges plunging at moderate angles to the south-west. The latter are statistically parallel to local bedding/cleavage intersection lineations on a micro-crenulation cleavage (S2) that poses as 'slaty cleavage'.

Inland mapping shows that three major faults cross the coast section and cause a significant displacement of the outcrop of the Dunoon Phyllites (Figure 9). Evidence for only one of these faults is seen on the coast section. The Highland Boundary Fault is marked by an erosional hollow at the south-eastern limit of the GCR site but is not exposed.

\subsection{Interpretation}

The lateral correlation of stratigraphical units recognized on the Rosneath peninsula is well established. The Bullrock Greywacke, a right-way-up unit of gritty and pebbly, feldspathic metagreywackes, correlates with rocks having a similar character from the Isle of Bute to Loch Lomond side; the Dunoon Phyllites equate with slaty metamudstones on the Isle of Bute and the Luss slates at Loch Lomond; and the inverted sequence of Beinn Bheula Schists seen north of the Dunoon Phyllites occupies the same relative structural position at all of these localities. The metabasaltic and associated rocks at Knockderry castle may be correlated with the green beds seen east of Loch Lomond.

The Bullrock Greywacke and Beinn Bheula Schists in the area of this GCR site, the 'greywacke affiliation' of Roberts (1966a), originated mainly as sequences of siliciclastic turbidites deposited in a submarine fan environment. In contrast, the Dunoon Phyllites were most likely deposited in a deeper water, oceanic setting, and consisted of pelagic muds diluted by the periodic influx of siliciclastic turbidites.

The structural situation is more enigmatic. On the Rosneath peninsula and at this GCR site in particular, the limbs of the major D1 structure, the Tay Nappe, are clearly defined by the thick unit of consistently inverted Beinn Bheula Schists (in the northwest) and the largely right-way-up Bullrock Greywacke (in the south-east), but the hinge-zone of this structure is difficult to locate.

This problem had been recognized earlier (Roberts, 1974; Paterson et al., 1990) and it was suggested that there is a major slide along the south-eastern margin of the Dunoon Phyllite outcrop, which cuts out some of the southern limb of the major fold. However, this does not agree with the evidence from outwith the peninsula that this boundary is a normal sedimentary contact (Paterson et al., 1990). There are two alternative possibilities; either the actual hinge-zone is poorly defined and is represented by a number of mesoscopic fold closures, or it is hidden by faulting. There is no field evidence to indicate the presence of mesoscopic folds in the Dunoon Phyllite. On the other hand, three large N-S-trending faults, each having a component of sinistral transcurrent displacement, cause a considerable displacement of the 
Dunoon Phyllites (Figure 9). The combined effect of this faulting is to remove about three kilometres of cross-strike exposure of the Dunoon Phyllites from view on the coast section within this GCR site. This 'hidden section' probably contains the closure of the Tay Nappe, with the folds seen to the south in the Bullrock Greywacke being congruous with the major fold.

The coastal section at this GCR site represents a depth profile of some $4 \mathrm{~km}$ through the Tay Nappe, at a time when it was a flatlying, or recumbent, anticline closing to the south-east (Tanner, 1992) (see the Introduction to Tanner et al., 2013b for a fuller explanation). At that time, the rocks at kilcreggan formed part of the top limb of this structure, and were at a higher level in the Earth's crust than those at Knockderry Castle, on the lower limb.

D1 minor structures dominate the southern part of the section, but north of Barons Point, the pervasive spaced or slaty s2 fabric overprints the earlier one and evidence of D1 vergence can no longer be recognized. D2 shear results in very regular planar S2 surfaces but several stages in the development of the D2 microlithons that formed at a high angle to the spaced s1 cleavage are preserved. These features provide a reliable fingerprint for identifying the D2 fabric in rocks of the Flat Belt to the north and enable complex fold interference patterns to be unravelled (see the Portincaple GCR site report, Figure 12). In some cases they show the relative shear sense during D2 deformation (Harris et al., 1976; Krabbendam et al., 1997).

Subsequently, the nappe was affected by two further deformations (D3 and D4), the second of which was responsible for rotating the rocks at this GCR site into their present steeply dipping attitude. The effects of these phases are best seen in the Portincaple GCR site, where the relationship of D2 to both D3 and D4, and the geometry of the Highland Border Downbend, may be examined.

\subsection{Conclusions}

The rocks seen in the coast section between Cove Bay and Kilcreggan belong to the upper part of the Southern Highland Group and are divided into three stratigraphical units. Both the Bullrock Greywacke and the Beinn Bheula Schists consist of coarse-grained, sometimes pebbly, metagreywackes that show graded bedding and cross-lamination. They were deposited in a submarine fan environment, whereas the Dunoon Phyllites, which consist largely of varicoloured slaty rocks, were deposited farther away from the continental margin in an oceanic basin setting. The exposures of the Dunoon Phyllites are of such quality as to constitute a reference section for this formation. All of the rocks have been deformed and metamorphosed subsequently during the Grampian Event of the Caledonian Orogeny, and now dip to the south-east at a moderate angle.

This GCR site provides a unique coastal section across the closure of the Tay Nappe, a structure that can be traced north-east-southwest across the Dalradian outcrop from the Isle of Bute to the east coast of the Grampian Highlands. The Bullrock Greywacke and the Beinn Bheula Schists, although rather different in lithology and mineralogy, have been correlated with each other, and are thought 
to represent the right-way-up limb and inverted limb, respectively, of the Tay Nappe. The Dunoon Phyllites, sandwiched structurally between them, occupy the core of the fold.

The great value of this GCR site is that it preserves structural information, in particular, that may be used to analyse and model early stages in the development of the Tay Nappe, and test the various hypotheses that have been proposed to explain its mode of emplacement. The evidence for the first two stages is charted by the sets of minor structures and cleavages so splendidly preserved in places in these rocks. In addition, there are few locations in the British Isles where the mechanisms involved in transforming an early, spaced, pressure-solution cleavage to a new cleavage of the same type can be studied in such detail.

\section{PORTINCAPLE (NS 227 928-NS 232 937)}

\section{P.W.G. Tanner}

\subsection{Introduction}

This GCR site is situated on the eastern shore of Loch Long at the small hamlet of Portincaple (Figure 1la). It consists of a rock platform fringing the coastline in the south, and low cliffs in the north that together expose an excellent section through the southern part of the hinge-zone of the Highland Border Downbend. This structure was responsible for rotating the Tay Nappe from an originally gently dipping orientation now represented by the Flat Belt, to its steeply dipping orientation in the Highland Border Steep Belt (as represented by the Cove Bay to Kilcreggan GCR site).

Here, the broad, open form of the F4 hinge-zone and the concordant geometry of the related minor structures are clearly shown. The geometry and vergence of D3 structures may also be readily examined, and there is clear evidence of their refolding by the major F4 downbend. The value of this site is also enhanced by the fact that it is the first significant accessible coastal section on the lower limb of the Tay Nappe north of Coulport, $5 \mathrm{~km}$ to the south. All of the intervening ground has been acquired by the Ministry of Defence and closed to public access.

The rocks consist of metagreywackes belonging to the Beinn Bheula Schist Formation. Bedding was thoroughly reworked during the formation of two pressure-solution cleavages (S1 and S2) and has been largely destroyed or rendered obscure during the process. However, a wealth of folded and overprinted cleavages, intersection and stretching lineations, and minor folds belonging to the three latest generations of structures, are very well preserved in clean rock exposures above mean tide level.

The Portincaple GCR site lies on the eastern margin of BGS 1:50 000 Sheet 37E (Loch Goilhead, 1990), but neither the map nor the original sheet memoir (Peach et al., 1905) provide any geological information specific to this site. The Tay Nappe and the manner in which it is bent down by the Highland Border Downbend were first recognised by Shackleton (1958), from mapping in adjoining areas 
and the hinge structure at Portincaple was first mapped by Stringer (1957). The area then received no further attention until Roberts (1977b) gave a brief description of the minor structures seen at Portincaple. This was followed by a more-detailed field guide to the locality by Tanner (1992).

\subsection{Description}

The Beinn Bheula Schist Formation belongs to the upper part of the Southern Highland Group and consists of fine- to coarse-grained metagreywacke and metasiltstone interbedded with lesser amounts of grey-green phyllitic rock. Bedding in these rocks has been largely destroyed, except in a few gritty, non-graded metagreywackes and one prominent, non-graded, pebbly metaconglomerate, less than $1 \mathrm{~m}$ thick, which appears to be little deformed.

The Beinn Bheula Schists are highly contorted due to the cumulative effects of four separate deformation events. The main planar element is the spaced 52 fabric, generally seen as anastomosing microlithons a few millimetres to over $1 \mathrm{~cm}$ thick, within which traces of the S1 spaced fabric can be seen in places. This fabric is identical to that which dominates the northern part of the Cove Bay to Kilcreggan GCR site but here it has been deformed by two further deformations, D3 and D4.

A SSE-plunging stretching lineation is seen as silky striations that make a high angle with the L2 on $\mathrm{S} 2$ cleavage surfaces. It is also present as quartz-fibre lineations in many of the quartzcarbonate veins.

The D3 deformation is represented by fairly common sidewaysclosing folds which invariably have the same vergence and $\mathrm{Z}$-shaped down-plunge profile throughout the area. The axial-planar dip of these folds varies in a progressive but non-systematic manner from $50^{\circ} \mathrm{N}$ at the southern end of the section, to around $20^{\circ} \mathrm{N}$ in midsection, to about $5^{\circ} \mathrm{N}$ at the northern end. The minor folds are on a decimetre scale and are curvilinear, plunging at a low angle to both east-north-east and west-south-west. In these rocks they fold the S2 spaced cleavage, the L2 intersection lineation seen on the S1 cleavage, and the stretching lineation (?L2). A weak S3 crenulation cleavage is largely restricted to the hinge-zones of these folds, where it cuts across and dissects the folded s2 cleavage.

Step-like, metre-scale, F4 minor folds are found throughout the coastal section (Figure 11b). These folds are open to close, upright structures that have nearly horizontal, slightly curvilinear fold hinges. Their steep limbs are parallel to the mean orientation of the foliation in the steep Belt, and the nearhorizontal middle limb is parallel to the general orientation of the same foliation in the Flat Belt (Figure 11b). The associated crenulation cleavage is near vertical and has a fairly constant strike $\left(070-080^{\circ}\right)$ but can be seen in the field to vary in dip about the vertical as a result of cleavage refraction through rock packages of differing competence. It is characteristically widely spaced (1-2 mm) (Figure 12c). Flat-lying kink bands that rework the S4 cleavage are seen locally. An equal-area stereographic plot 
of poles to $\mathrm{S} 2$ and $\mathrm{S} 4$ shows that the major fold plunges at $10^{\circ}$ to $079^{\circ}$ (Figure 11C).

A number of faults are seen in the southern part of the GCR site. They are either vertical or dip steeply to the south and have a mean spacing of about $4 \mathrm{~m}$ (Figure 11b).

\subsection{Interpretation}

This GCR site is situated at the northern extremity of the Highland Border steep Belt where it turns into the antiformal closure of the Highland Border Downbend, which is in effect a monoform. The northern limb of the downbend (the Flat Belt) is best seen $3 \mathrm{~km}$ farther north near Glenmallan (NS 249 965), where the exposures are on two natural rock platforms formerly accessed by fixed steel ladders from road level. There, the composite s1/s2 fabric is generally flat-lying but is affected by strongly developed upright F4 folds associated with a steep to vertical crenulation cleavage.

In the southern part of the Portincaple GCR site, F4 minor folds with wavelengths of over $2 \mathrm{~m}$ are clearly congruous to a major antiformal structure to the north and adopt a neutral vergence in northern part of the section as the major fold hinge-zone is entered. The axial trace of the major antiform/monoform trends parallel to the strike of the measured crenulation cleavage and this fold correlates with that identified on Loch Lomondside by Stringer (1957) and Shackleton (1958).

No major $\mathrm{F} 3$ folds have been recognized in this area and this phase of folding appears to have only local significance, for D3 structures are absent to the north-east along strike from Aberfoyle (Tanner and Leslie, 1994) (see the Craig a' Barns GCR site report). Ever since it was first discovered by Clough (in Gunn et al., 1897), there has been disagreement over the relative age of the downbend, but from the data presented here it is clear that it is a D4 structure.

\subsection{Conclusions}

The Portincaple GCR site provides the best accessible coastal section through part of the hinge-zone or closure of the Highland Border Downbend to be found in the south-western Grampian Highlands. This major D4 structure is responsible for folding the Tay Nappe into a downward-facing structure along the entire Highland Border zone from Loch Lomond to Stonehaven.

At this GCR site, minor structures formed in all four of the main deformation episodes to affect the Dalradian succession can be identified, and it is an excellent section for demonstrating the effects of three-dimensional polyphase deformation. Geometrical integrity of individual phases can be demonstrated, despite the seemingly chaotic assemblage of ductile structures and the complexity of their interference patterns. The clean rock exposures provide a wealth of information on the minor folds, cleavages, lineations, veins and fracture geometry found in this complex zone.

This site could be considered as the type section for studying the D3 deformation and for separating it clearly from the effects of D2 
and of D4. It therefore contrasts with and complements the section farther north-east in the Birnam area at the Craig a' Barns GCR site, where D3 is not developed.

\section{BEALACH NAM BO (NN $479 \quad 065-N N \quad 485 \quad 079$ )}

\section{C.W. Thomas}

\subsection{Introduction}

Bealach nam Bo (Gaelic: 'Pass of the cattle') is a narrow pass formed by a glacial overflow channel on the northern flanks of Ben Venue, immediately west of the southern end of Loch Katrine in the Trossachs (Figure 14). It lies at the centre of this GCR site, which comprises about $4 \mathrm{~km}^{2}$ of ground underlain by volcaniclastic metasandstones, ubiquitously referred to as 'green beds', and quartzrich, gritty and commonly pebbly metasandstones, assigned to lithostratigraphical units within the lower part of the Southern Highland Group. The green beds are distinctive and have been treated as lithostratigraphical markers. The numerous exposures around Bealach nam Bo illustrate the wide range in styles, varying according to lithology, of the commonly spectacular structures associated with the second phase of deformation and the nature of the interaction between the first and second phases.

The area around Bealach nam Bo was mapped in the latter part of the nineteenth century by officers of the Geological Survey, but the manuscript for the accompanying memoir was never published and has only recently been made available (Cunningham Craig, 2000). Subsequently, the ground immediately south of the pass was included in R.M. Shackleton's work on the structure of the Dalradian rocks adjacent to the Highland Border (Shackleton, 1958). He showed that the metasedimentary rocks are inverted, young towards the south and dip steeply northwards. He also noted a conspicuous 'later fracture-cleavage or slip-cleavage', now known to result from the main phase deformation, described below. The area was resurveyed by the British Geological Survey between 1996 and 1998 as part of the general mapping programme and lies within the BGS 1:50 000 Sheet 38E (Aberfoyle, 2004).

\subsection{Description}

The metasedimentary rocks within the GCR site area include green beds and associated metasandstones in the north, structurally overlying commonly gritty or pebbly, quartz-rich metasandstones in the south. Finer grained metamudstones and metasiltstones are generally rare. Although bedding generally ranges up to $1 \mathrm{~m}$ in thickness, some massive and coarse-grained beds are in excess of 2 m thick. Graded bedding is commonly developed and shows that the steep northerly dipping succession is generally inverted. Determination of way-up of the succession in this and adjacent areas has been critical in understanding the structural history of the rocks within the site, and in the region in general. 
Following the BGS resurvey, the green beds and associated rocks have been assigned to the Loch Katrine Volcaniclastic Formation (Figure 14). The green beds are chlorite- and epidote-rich metasandstones, locally with abundant magnetite. The background sediment with which the abundant mafic minerals were mixed is fine to coarse grained, quartz rich and commonly gritty. The chlorite and epidote impart an olive to dark bottle-green colour to fresh surfaces, but the green beds weather to a characteristic sandy brown colour, often with a sandpaper-like surface texture where finer grained. The weathered rind extends up to a centimetre or so into the surface. Careous weathering is also a feature in places, yielding a surface honeycombed by rounded pits up to about $15 \mathrm{~cm}$ across and $3 \mathrm{~cm}$ deep. Although the green beds display little visible lithological variation in individual exposures, small lenses of quartz-rich, gritty metasandstone are quite commonly developed, often serving to highlight bedding.

The metasandstones associated with the green beds are chiefly coarse-grained, gritty quartz- and feldspar-rich metasandstones with only small amounts of chlorite and epidote. Although there is, in effect, a continuum in composition between these and the green beds, individual green beds are commonly sharply enough defined to be mapped out as separate units within the Loch Katrine Volcaniclastic Formation.

Typical green-bed lithologies are very well exposed in cliffs at Bealach nam Bo and on ground to the south-west and north-east. In these outcrops, they are massive, thickly to very thickly bedded units of coarse metasandstone, as detailed in the sedimentary log in Figure 15. A notable feature of some beds is the presence of ellipsoidal, nodular structures concentrated in bedding-parallel trains. They are up to about $10 \mathrm{~cm}$ long in the longest dimension and usually have weathered-out cores.

The metasandstones that lie lithostratigraphically above, but structurally underneath, the Loch Katrine Volcaniclastic Formation are assigned to the Creag Innich Sandstone Formation (see also the Duke's Pass GCR site report). These are predominantly clean, quartz-rich, coarse metasandstones with minor intercalations of metasiltstone and more-micaceous metasandstone. In places, spectacular pebbly lithologies form microconglomeratic units that can exceed $2 \mathrm{~m}$ in thickness; good examples of such rocks are to be found on the higher ground $c .600 \mathrm{~m}$ south-west of Bealach nam Bo (around NN 478 069). The pebbly rocks are notable for their wellrounded pebbles, their compositional maturity (chiefly quartz-vein material) and their high degree of sorting.

The structures developed in the metasandstones within and around the GCR site are complex, but allow the relationships between the regional first (D1) and second (D2) phases of deformation to be discerned. Although the D2 phase affected the whole region, it is the lithologies and the architecture of the structures formed during D1 that control the ways in which D2 structures are manifest at both local and outcrop scale.

The very thick and massive green-bed lithologies, such as those exposed in the cliffs at Bealach nam Bo (NN 480 070), commonly appear to be only weakly deformed and cleavages are poorly developed. In the exposures of metasandstones to the west and 
north of the pass, metre- to decimetre-scale, south-verging folds are common. In general, the hinge-zones of these folds host only a single, moderate, penetrative, axial planar cleavage, good examples of which are seen in exposures around NN 478075 (Figure 16). Even though this cleavage might have been modified by subsequent D2 deformation, it is considered to result principally from D1 deformation. This style of cleavage is very different to the coarsely spaced, anastomosing S1 cleavage characteristic of metasandstones that crop out to the south of the GCR site, towards the Highland Boundary Fault.

Bedding dips consistently and steeply to the north-north-west on either side of the Fl axial traces, showing that these early folds are tight to isoclinal. The Fl folds plunge consistently to the north-east at moderate angles. Abundant younging evidence, combined with bedding/cleavage relationships, shows that the F1 folds face steeply downwards to the north-north-west throughout the area.

The second phase of deformation, D2, is characterized by a coarse crenulation of the first cleavage; $\mathrm{S} 2$ is approximately parallel to bedding on the long limbs of $\mathrm{F} 1$ folds. The D2 crenulation is particularly well developed in the ground $C .400 \mathrm{~m}$ south-west of Bealach nam Bo (around NN 477 071). In general, the first cleavage is folded by D2 folds on a small scale (Figure 17), but bedding is not affected. The small-scale F2 folds plunge to the north-east and south-west and commonly have strongly curvilinear hinges. The style of folding varies from a chevron type with planar limbs and very sharp angular hinges, to a type that has the sinusoidal form of a classical crenulation. Domains bounded by the s2 cleavage planes ('microlithons') can be planar but are more typically lenticular in shape. Discrete s2 cleavages only form locally within the hinges of chevron-style folds and are rarely intensely developed. In lenticular, crenulated domains, the cleavage that defines the lenticle margins is a composite S1-S2 fabric. This cleavage is discontinuous along its length and is variably and widely spaced.

\subsection{Interpretation}

The lithologies that occur within the Bealach nam Bo GCR site are typical of Southern Highland Group metasedimentary rocks in general. The green beds are interpreted as metasandstones with a mafic volcaniclastic component, the latter derived either from contemporaneous or near-contemporaneous volcanic rocks, such as those in the Tayvallich peninsula of the South-west Grampian Highlands, or from the reworking of older volcanic terrains. How the nodular structures formed is unclear at present; Cunningham Craig (2000) suggested that they might have originated as claygalls, although it is possible that they could have had a volcanic origin.

The cleaner metasandstones associated with the green beds and within the Creag Innich Sandstone Formation are evidence that the background sedimentation was dominated by generally coarse sand deposited by turbidity currents and mass debris flows. The pebbly component is likely to have been derived from a mature, well-sorted 
beach deposit within the source area and admixed during redeposition with the finer grained sediment that forms the matrix.

Although the D2 phase of deformation affected the whole area, the various styles and characteristics of the D2 folding indicate that D2 strain was variable, generally not very high and locally partitioned. The finely spaced cleavage observed in the Fl fold hinges in green beds is considered to be primarily the result of D1 deformation, even though the cleavage might have been enhanced by coplanar D2 deformation. In addition, the variations in style and distribution of D2 structures indicate that S1 cleavages in the cleaner metasandstones were already closely spaced to penetrative on the grain scale before the D2 small-scale folding. This closer spacing contrasts with the wide, anastomosing s1 cleavage observed in coarse metasandstones to the south-east at the Duke's Pass GCR site. This suggests that D1 deformation was generally more intense at this structural level within the Tay Nappe than at higher structural levels to the south-east. Alternatively, the closer spacing of the S1 cleavage could be due to early D2 deformation modifying the spacing by flattening, prior to simple-shear folding of the S1 cleavages (see the Craig a'Barns and Rotmell GCR site reports). As discussed elsewhere in this special issue, there are strongly contrasting views on the significance of D2 deformation in the Highland Border region (Harris et al., 1976; Harris and Bradbury, 1977; Roberts, 1977a; Mendum and Fettes, 1985; Krabbendam and Leslie, 1996; Krabbendam et al., 1997; Mendum and Thomas, 1997). The arguments are not rehearsed again here, but it is considered that the evidence within the Bealach nam Bo site is consistent with north-westerly directed simple shear during at least the latter part of the D2 phase.

The steep north-north-west dips of bedding and the downward-facing character of the Fl folds result from overturning of the folded succession by a much later phase of deformation. This deformation is generally considered to have occurred prior to the main D4 compressive phase (see Stephenson et al., 2013a) and is responsible for the steep dips developed in this and other areas along the south-eastern margin of the Grampian Highlands (e.g. Harte et al., 1985 ).

\subsection{Conclusions}

The Bealach nam Bo GCR site provides numerous outstanding and readily accessible exposures that reveal clearly the contrasting nature of two formations in the Southern Highland Group, both in terms of rock type and the response of these units to regional deformation events.

Metasandstones in the Loch Katrine Volcaniclastic Formation commonly contain volcaniclastic detritus, now manifest as chlorite, epidote and locally abundant magnetite. This detritus is sufficiently abundant in many beds within the formation to impart a strong, dark-green colour from which the 'green beds' derive their name. This detritus might have been derived from contemporary volcanic activity, although this is, as yet, unproven. The rocks within the overlying Creag Innich Sandstone Formation are dominated 
by clean, coarse metasandstones and locally spectacular, pebbly metaconglomerates, rich in well-rounded vein-quartz clasts.

The green beds appear to have undergone relatively simple deformation dominated by cleavage and folding resulting from the first regional phase (D1), although there might have been some modification during the second deformation phase (D2). Folds resulting from the first phase of deformation are very well exposed locally and there is ample sedimentological evidence of the way-up of beds; this allows the steeply downward-and NW-facing character of the folds to be readily demonstrated. The metasandstones of the Creag Innich Sandstone Formation are notable for the range and complexity of minor structures developed within them as a result of interaction between the D1 and D2 deformations. These observations provide important insights into the overall structural evolution of the Highland Border region.

\section{DUKE'S PASS (NN 499 030-NN 523 043)}

\section{C.W. Thomas}

\subsection{Introduction}

The Duke's Pass is followed by the A821 road between Aberfoyle and the west end of Loch Achray. Ground extending either side of this corridor provides numerous, readily accessible exposures of metasedimentary rocks belonging to the Southern Highland Group, which comprise the GCR site (Figure 18). The GCR site is particularly important in revealing the nature of the earliest phase of deformation, free of the effects of the main second deformation event, and the way in which the second deformation modified the earlier structures.

The Aberfoyle district was important in early work on the Dalradian, yielding the now well-known names of some of the key lithostratigraphical units in the Southern Highland Group, especially the Aberfoyle Slates and Ben Ledi Grits. A resurvey by the British Geological Survey of 1:50 000 Sheet 38E (Aberfoyle, 2004) has delineated other lithostratigraphical units and has determined that faults related to the Loch Tay Fault system are responsible for the mismatch of structures and outcrop pattern across the Duke's Pass.

The area is of major importance in determining the 3-D structure of this segment of the Highland Border region. The high degree of deformation was recognized during the original mapping by the Geological Survey in the late 19th Century (original unpublished manuscript released as Cunningham-Craig, 2000), although its precise nature and significance for the tectonic evolution of the Grampian Terrane was not recognized until the latter half of the twentieth century. Henderson (1938) was the first to demonstrate the way-up of the beds from sedimentary structures and showed that the Aberfoyle Slates occupy the core of the 'Aberfoyle Anticline'. Anderson (1947a) maintained that this structure extends along the Highland Border from West Water in the Edzell district, Angus, to 
the Isle of Arran in the south-east. Subsequently, Shackleton (1958), in his seminal paper on the structure of the Dalradian rocks of the Highland Border, demonstrated that the structures observed on either side of the Aberfoyle Slates are downwardfacing. The slaty metamudstones thus occupy the core of a downward-facing anticline, constituting the inverted nose of the Tay Nappe. Mendum and Fettes (1985) showed that at least two other major early folds, complementary to the Aberfoyle Anticline, occupy ground to the north of the latter structure and lie structurally beneath it. This renders the hinge-zone of the Tay Nappe much more complex than envisaged by Shackleton. The Aberfoyle Anticline is thus just one of a number of early structures in the hinge-zone of the nappe. The northern half of the GCR site is affected by a second deformation and local, minor development of later cleavages, which become more intense northwards.

\subsection{Description}

The GCR site lies entirely within the Highland Border Steep Belt, the domain of steeply, generally north-west- to north-dipping strata that occupy the ground south of the Highland Border Downbend (Stephenson et al., 2013a, fig. 7). It also lies to the north-west of the Loch Tay Fault Zone, which in this area trends south-west from the north-west side of Meall Ear (NN 530 027), passing immediately south-east of Creag Gownan (NN 533 025) and the lower slopes of Craigmore (NN 510 021) (Figure 18).

Within the GCR site, the Southern Highland Group is dominated by metasandstones. Although most of these were originally wackes, carrying abundant matrix, many were quartz-rich arenites. The very local nature of lithological variation within the metasandstones limits the potential for lithological subdivision. However, mapping by the British Geological Survey has delineated three discrete metasandstone units on the western side of the Duke's Pass Fault (Figure 18). Graded bedding is very commonly developed and other sedimentary structures, which help to constrain the way up, include scours, load structures and, very rarely, ripple marks. Rip-up clasts, now metamudstone, are abundant locally and can reach several tens of centimetres in size. The way-up criteria are critical to the understanding of the structure of the Duke's Pass area (see below).

The bulk of the metasandstones are assigned to the Ben Ledi Grit Formation. In this unit they vary from massive, very thick, gritty to locally pebbly coarse metasandstones to thin-bedded, finegrained units with metasiltstone and locally metamudstone interbeds. The coarser grained lithologies dominate. Excellent examples of the coarse-grained lithologies are exposed on the low hillside around NN 518 031, where they occupy a fold hinge (see below). Here, basal scours contain gravel lag deposits and loading structures are common where very coarse material has been deposited on finer grained units.

To the west of the Duke's Pass and north of the Aberfoyle slate quarries, metasandstones are assigned to the Creag Innich Sandstone Formation. They are grey, coarse-grained, quartz-rich, medium- to thick-bedded rocks that crop out extensively in the high ground, 
particularly around Creag a Mhadaidh (NN 513 036). This formation lies below the Ben Ledi Grit Formation, but appears to be laterally discontinuous on a regional scale (Thomas et al., in press). The metasandstones in this formation are generally cleaner, with less fine-grained matrix, than those of the Ben Ledi Grit Formation.

To the north of the Creag Innich Sandstone, metasandstones are assigned to the Ledard Burn Member, a generally finer grained unit within the Ben Ledi Grit Formation. This unit comprises mediumbedded, fine-grained metasandstones with metasiltstone interbeds; thin gritty units are present at the bases of some upward-fining packets of sandstone.

Metasiltstone and metamudstone are common as interbeds and laminae in many of the metasandstones. They also occur in much thicker units, the most notable of which forms the Aberfoyle slate Formation west of the Duke's Pass Fault, which is well exposed in the abandoned Aberfoyle Slate Quarries (NN 505 032). This unit is dominated by grey and greenish or purplish grey metasiltstones with darker laminae of metamudstone. Bedding is commonly picked out by discontinuous thin wisps of quartzose material. Way-up is rarely determinable in these rocks, but very locally the thin quartzose laminae contain discernible cross-lamination and have small-scale scours at their bases, indicating the direction of younging. The Aberfoyle Slate Formation contains the oldest Southern Highland Group rocks within the GCR site, these rocks being correlated traditionally with the Pitlochry Schist of Perthshire. They were worked extensively for slate in the Aberfoyle quarries in the 19th century before extraction become uneconomic in the face of competition from lighter and higher quality Welsh slate.

The metasiltstones of the Aberfoyle Slate Formation pass southwards into pale, quartzose metasandstones that are correlated, on the basis of recent BGS mapping, with the Creag Innich Sandstone Formation to the north. The metasandstones pass southwards, in turn, into the more-impure metasandstones, metasiltstones and subordinate metamudstones of the Ben Ledi Grit Formation, the outcrop of which continues to the Highland Boundary Fault at the southern margin of the GCR site.

East of the Duke's Pass, within the Achray Forest, a unit of metamudstone within the Ben Ledi Grit Formation is bounded to the east by the Loch Tay Fault and to the west by smaller faults (Figure 18). The metamudstones are black, grey, green or maroon in colour and are strongly cleaved. In the ground immediately west of and within the Loch Tay Fault Zone (200-300 m west of Meall Ear, NN 530 027), metamudstones are black, rich in pyrite and contain cherty laminae. These lithologies are similar to those seen in the Leny Quarry (NN 619 101), north-west of Callander (see the Keltie Water GCR site report), but differ significantly from those exposed in the Aberfoyle slate quarries. Thinner units of metasiltstone and metamudstone, such as that trending eastwards about $500 \mathrm{~m}$ north of Aberfoyle, occur throughout the general mass of Ben Ledi Grit to the east of the Duke's Pass Fault and are generally similar lithologically to those described above. Hence, contrary to previous interpretations (Shackleton, 1958; Mendum and Fettes, 1985), the fine-grained rocks to the east of the Duke's Pass Fault are not lithostratigraphical correlatives of those seen in the 
Aberfoyle slate Quarries. The corollary is that there has been considerable displacement across the Duke's Pass Fault, resulting in the juxtaposition of different lithostratigraphical units and different structural levels (see below).

Bedding in the metamudstones, very rarely observed, is picked out by very thin silty laminae or by subtle variations in hardness that indicate a more siliceous layer. Metre- to decimetre-scale folding in these rocks is well observed in exposures on a forest track west of Creag Gownan, at NN 520 024. Very fine-scale graded bedding in silty laminae shows that the rocks are inverted and that the folds and first cleavage face downwards.

The southern part of the GCR site, south of Hill Cottage (NN 515 031), contains exposures that reveal the nature and geometry of the D1 deformation, free from the effects of subsequent deformation events, most particularly D2. Outcrops of thick-bedded, very coarse wacke metasandstone on the eastern flanks of Craigmore (NN 510 021) lie in large-scale F1 fold closures, as indicated by locally variable and moderate easterly dips and by high-angle intersections between bedding and cleavage. The dominant S1 cleavage is widely spaced (c. $0.5-1.0 \mathrm{~cm}$ ) and anastomosing in the coarse-grained lithologies, becoming more finely spaced where the grain size is less. This cleavage is the Slp cleavage of the Little Glen Shee, Craig a'Barns and Rotmell GCR sites.

The exposures on the low hills immediately east of Hill Cottage lie within an antiform, the core of which contains very coarse metasandstones with locally developed gravel lags filling scours in bed tops. Graded bedding is well developed in these rocks, showing unequivocally that the fold is a syncline facing downwards on the first cleavage. The dominantly strongly oblique relationship between bedding and first cleavage displayed in the coarse metasandstones shows that most exposures lie within or close to fold hinges throughout the area. The F1 folds are tight to isoclinal and are generally on the decimetre scale or larger (Figure 19).

Moving north-westwards from the Highland Boundary Fault in this area, D2 structures are first seen in the coarse metasandstones of the Creag Innich Sandstone Formation to the north of Hill Cottage on the western side of the Duke's Pass and are clearly observed in exposures above the A821 road in the area around NN 518 040. D2 structures occur only as cleavages within the Duke's Pass GCR site, but these are widely enough spaced to appear as stacks of F2 minor folds of the S1 spaced cleavage (cf. Booth, 1984; Harte et al., 1987). Large F2 folds of bedding are not observed. Where it is more intense, the $\mathrm{S} 2$ cleavage is in general nearly parallel to the steep north-dipping bedding. Towards its southern limit, it is commonly more oblique to bedding, dipping generally at shallower angles to the north. In the northern part of the GCR site, the S2 cleavage is more intensely developed and becomes the dominant fabric, manifest as a strongly planar spaced cleavage, particularly in the finer grained lithologies. D2 structures and their effects on S1 are particularly well observed at the northern limit of the GCR site at Craig Noran (NN 504 066), just north of the Achray Hotel. Here, graded bedding in a thin, coarse-grained unit beneath a massive, thick gritty metasandstone unit shows that the beds are 
inverted. The Sl cleavage is nearly normal to the coarse-grained, thick bed and is clearly deformed by D2, the latter resulting in a locally developed, widely spaced crenulation cleavage. The nearparallelism between $\mathrm{S} 2$ and bedding is readily apparent.

Effects of the D4 deformation related to the formation of the Highland Border Downbend, as seen elsewhere along the Highland Border (e.g. at the Craig a'Barns GCR site), are developed only very locally within the northern part of this GCR site. For example, a shallow and northerly dipping crenulation cleavage is developed in metamudstones in a small exposure by the A821 road at about NN 516051.

\subsection{Interpretation}

The overall lithological character and the bedforms of the coarseto very coarse-grained metasedimentary rocks in the Duke's Pass area indicate that they were deposited by turbidity currents and debris flows within major channels of a fan system on a continental margin. They are, therefore, just part of the much more-extensive, extremely dynamic, depositional system manifested by the Southern Highland Group throughout the Dalradian outcrop of Scotland and Ireland (Burt, 2002). In such an environment it is likely that the finer grained rocks represent off-channel or overbank deposits. However, the locally developed, black, cherty, sulphidic metamudstones near Meall Ear (NN 530 027) suggest that moreeuxinic, pelagic or isolated basinal sedimentation occurred at times. This might have reflected a major geographical shift in the depositional system as much as a major deepening of the depositional basin.

Faulting is an important feature of the Duke's Pass area, which contains the southern end of the Loch Tay Fault system. The Loch Tay Fault is known to have experienced several kilometres of oblique, sinistral strike-slip movement (Treagus, 1991). This precludes any close correlation of lithostratigraphical units across it in the Aberfoyle area, despite apparent lithological similarities. This problem applies equally to the related Duke's Pass Fault and other parallel faults within the area. Notable effects of the Duke's Pass Fault include the apparent displacement of the incoming of D2 deformation, which is farther to the northeast and in a different lithostratigraphical unit on the eastern side, implying a significant change in structural level across the fault (Figure 18).

The structures reveal that the Duke's Pass area is occupied by a major Fl fold system. The original interpretation of a single synformal closure centred on the Aberfoyle Slate Formation is likely to be an over-simplification. Evidence for extensive long fold limbs is lacking and fold hinges are commonly observed, either directly or via the changes in bedding/cleavage relationships. Mendum and Fettes (1985) have already shown that the Highland Border steep Belt in this area is occupied by regional-scale Fl nappe structures that lie structurally beneath the Aberfoyle Anticline. The structural evidence in the Duke's Pass area, outwith the effects of D2, indicates the presence of a complex F1 fold hinge-zone, which is most easily interpreted as the front of a 
major nappe structure of which the Aberfoyle Anticline is part. The style and degree of deformation in the metasedimentary rocks suggest that the southern part of the Duke's Pass GCR site, southeast of the Duke's Pass Fault, is occupied by the upper and outer structural parts of this nappe front.

Based on the younging and structural evidence in the Duke's Pass area, D2 structures only begin to appear at deeper structural levels within the F1 nappe system. Hence, the absence of D2 effects in the southernmost part of the GCR site suggests that these rocks were originally at higher structural levels and allows the original geometry of the major Fl fold structures to be discerned. The field evidence indicates that the F1 nappe and fold structures were recumbent when formed; their current attitude in the south of the GCR site resulted essentially from rotation around the late Highland Border Downbend and subsequent compression during D 4 .

Observations on the effects of D2 deformation on S1 cleavages in particular, made in the Duke's Pass and Bealach nam Bo GCR sites, strongly suggest that D2 deformation was dominated by $N W$-directed simple-shearing accompanied by flattening (Mendum and Fettes, 1985; Mendum and Thomas, 1997). This interpretation differs fundamentally from those of other workers who interpreted the Tay Nappe and related structures as resulting from the combined effects of D1 and SE-directed D2 deformation, the latter dominated by simple-shearing (Harris and Bradbury, 1977; Krabbendam et al., 1997). Thus, the evidence from the Duke's Pass area, combined with that from other GCR sites in this paper (Little Glen shee, Craig a'Barns, Rotmell, Garron Point to Muchalls), is critical to the debate on the nature of the early orogenic events that affected the south-eastern part of the Grampian Terrane as a whole (see discussion by Stephenson et al., 2013a).

\subsection{Conclusions}

The Duke's Pass between Aberfoyle and Loch Achray provides outstanding and readily accessible exposures of Southern Highland Group metasedimentary rocks. These exposures not only reveal the nature of the processes that deposited the original sediments, but also the effects of the subsequent, mainly ordovician deformation. The coarse metasandstones were deposited by sediment-laden currents (turbidity currents) and debris flows within major channel systems in a marine fan delta complex on a continental margin.

The rocks were deformed several times. The dominant early structures were flat-lying, kilometre-scale folds, of which the Aberfoyle Anticline is the best known. The true nature and orientation of the early structures are revealed in the southern part of this GCR site, because there they are unaffected by the second deformation, which is observed in the northern part of the site. There, the relationship between the first and second phases of deformation can be readily discerned; the second structures are largely parallel to the original bedding and their main effect was to deform the first cleavage.

The structural evidence indicates that the rocks in the southern part of the site occupied the upper and outer part of the uppermost 
of the major nappes in the region, probably close to the nappe front. The present steep orientation of the bedding and downward facing of the folds arose from refolding of the rocks around the Highland Border Downbend, a major late fold that re-orientated the nose of the nappe structures.

\section{KELTIE WATER, CALLANDER (NN 644 120-NN 633 131)}

\section{P.W.G. Tanner}

\subsection{Introduction}

The Keltie Water is a spate stream whose rocky bed and low cliffs provide the most-complete and best-exposed section through the uppermost Dalradian sequence to be found in the Highland Border region. The rocks consist of an inverted succession of low metamorphic grade slaty pelites and gritty metasandstones, with subordinate metalimestones, which dip northwards at a low to moderate angle (Figure 20). They lie stratigraphically well above the Aberfoyle Slate Formation (see the Duke's Pass GCR site report), and the older part of the sequence is equated with the Ben Ledi Grit Formation of the Southern Highland Group. Structurally, the rocks lie on the south-east limb of the downward-facing F1 Aberfoyle Anticline, which is the local equivalent of the main closure of the Tay Nappe.

The geology of the Keltie Water section has aroused much interest and controversy since it was first examined in detail by Clough (in Geikie, 1897, p. 28); the early history of research has been reviewed by Tanner (1995). The most significant contributions were made by Clough, who concluded that it is not possible to make a clear distinction between undoubted Dalradian rocks in the north and other rocks farther south; by stone (1957), who recognized a single southward-younging sequence, and disproved Anderson's (1947a) interpretation that the rocks now referred to as the Keltie Limestone and Shale Member (Figure 20) occupy a synclinal infold in the metasandstones; and by Harris (1962, 1969), who concluded that there is no evidence for a major stratigraphical or structural break within the Keltie Water section. The subsequent debate has focussed on whether or not there is stratigraphical and structural continuity between undoubted Dalradian rocks belonging to the Ben Ledi Grit Formation (which crop out in the northern part of the river section) and a younger group of rocks found farther south, named the Keltie Water Grit Formation (Tanner, 1995). A full understanding of the relationship between these two groups of rocks is vitally important, for the Keltie Water Grit Formation includes the fossiliferous Leny Limestone, which is of late Early Cambrian age (Pringle, 1940; Brasier et al., 1992).

If stratigraphical and structural continuity between undoubted Dalradian rocks and the Keltie Water Grits can be demonstrated in the Keltie Water section, it follows that the deformation that has affected the southern part of the Dalradian block must be younger than Early Cambrian in age, specifically post $519 \mathrm{Ma}$ (Tanner and 
Pringle, 1999); a conclusion that has profound implications for the age of the Grampian Event in the Scottish Caledonides. The alternative, strongly argued, viewpoint (Bluck and Ingham, 1997; but see Tanner, 1997) is that there is a major structural break between these two rock units, which is interpreted as a terrane boundary separating the Dalradian succession sensu stricto from the Keltie Water Grits (Brasier et al., 1992). In this scenario, the Leny Limestone and Keltie Water Grits would be part of the Highland Border complex, which is interpreted by those authors as an exotic terrane that docked with the Dalradian of the Grampian Terrane in late-Silurian to Devonian times. In this case, separation of the fossiliferous rocks from the Dalradian by a terrane boundary would remove any restriction on the maximum age of the deformation of the Dalradian rocks, and hence on the timing of the Grampian Event. The rocks exposed in the Keltie water provide some of the key evidence for deciding between these two opposing hypotheses.

The other important feature of this site is the faulted contact of the Keltie Water Grits against Lower old Red Sandstone conglomerate and volcanic rocks seen at the southern limit of the stream section. This fault has been referred to as the 'Highland Boundary Fault'.

\subsection{Description}

The emphasis in this account is upon the rocks exposed in the Keltie Water and the lower part of its tributary, the Allt Breacnic (Figure 20). These rocks, referred to as the 'Leny Grits' by previous authors, were divided by Tanner (1995) into two main parts, from north to south:

(1) undisputed Dalradian rocks, mainly green gritty metasandstones, which are petrographically similar to those of the Ben Ledi Grit Formation in the classical Dalradian sequence farther north; and (2) the Keltie Water Grit Formation, which comprises a thick sequence of pale-coloured gritty metasandstones associated with grey and black slaty horizons, and includes a Transition Member of metasandstones and slaty pelites at the base.

All of the metasandstones in the c. $1.4 \mathrm{~km}$-thick sequence exposed in the Keltie Water section are of turbidite facies and have a very similar field appearance. They preserve abundant way-up evidence from graded bedding, and less common cross-lamination, in beds that consistently preserve bottom structures, probably modified loadcasts. This sequence is affected by faults and is cut by many, thick, irregularly shaped bodies of felsite (?late Caledonian) and two dolerite dykes of Palaeogene age.

\subsubsection{Stratigraphy}

Exposures in the upper part of the Allt Breac-nic are in massive gritty metasandstones with few minor structures or cleavages. The southern boundary of the Ben Ledi Grit Formation has been drawn at the southern limit of green and grey-green gritty metasandstones with abundant chlorite, detrital pink feldspar, and quartz (commonly pale blue). Workers familiar with the Southern Highland Group would confidently label these rocks as 'Dalradian'. They 
almost certainly interdigitate with those of the Transition Member to the south, and include rare pale-coloured metasandstones similar to those commonly found in the main part of the Keltie Water Grit Formation.

The Transition Member comprises green, grey-green, brown and palecoloured gritty metasandstones with green, grey and purple slaty pelites. The limit of the green-coloured rocks southwards marks the southern boundary of the transition and is accompanied by the incoming of grey and white metasandstones characteristic of the Keltie Water Grit Formation. The latter occur together with grey, black and variegated slaty pelites. The pale-coloured metasandstones are generally clast-supported, highly siliceous and have much Fe-rich carbonate in their matrix, so explaining why they are much more deeply weathered than the greenish coloured metasandstones to the north.

The Keltie Limestone and Slate Member appears to be a local facies development within a sequence of metasandstones that all young to the south-east. The black slaty pelites forming the middle unit contain numerous beds of orange-weathering, finely laminated carbonate rock, which contains abundant ferroan dolomite. A metresized lens of calcite metalimestone (the Keltie Limestone) is exposed in a small disused working at NN 6468 1252; major and trace element analyses show that it has the same overall composition as the Leny Limestone (Tanner and Pringle, 1999).

The black slaty pelites, which are part of the Leny Limestone and Slate Member, can be traced intermittently from Leny Quarry to the Keltie Water, and are correlated with the southernmost exposures of pelites found in the Keltie Water section. A full account of the setting, age, and correlation of the metalimestone, which is only exposed in Leny Quarry some $4 \mathrm{~km}$ south-west of the Keltie Water, is given in a GCR site report for that locality (in Rushton et al., 1999) and in the paper by Tanner and Pringle (1999). The Leny Limestone and Slate Member consists of contorted and brecciated dull green to black slaty pelites with some chert bands, and grey and purple slaty pelites, intruded by $55 \mathrm{~cm}$ - and $15 \mathrm{~m}$-thick dolerite dykes and by bodies of felsite; no metalimestone has been positively identified from these rocks in the Keltie Water section.

A detailed petrographical study of the entire sequence from the Ben Ledi Grit Formation to the southernmost exposure of the Keltie Water Grit Formation (Tanner and Pringle, 1999) has shown that the gritty metasandstones making up the bulk of this sequence have a distinctive detrital mineralogy throughout of quartz, plagioclase feldspar, white mica, biotite, tourmaline and zircon. K-feldspar is absent, and the amounts of detrital plagioclase and biotite decrease stratigrphically upwards. However, metasandstones of comparable grain size throughout this sequence show no discernable difference in petrographical features such as grain shape, strain fabrics and state of preservation of detrital micas (Figure 21).

\subsubsection{Structure}

Bedding throughout the section is generally inverted and dips to the north, except locally on the middle limbs of metre-scale minor folds where the beds are right way up and in places dip southwards. 
The main cleavage is a spaced cleavage in the metasandstones, with microlithons up to $2 \mathrm{~cm}$ thick (Figure 22). It appears, in exposures and under the hand-lens, to be a slaty cleavage in silty and argillaceous rocks. The cleavage is axial planar to the minor folds, or forms weak cleavage fans symmetrical to them; the folds have a variable plunge, which is gentle in the north but more variable and steep (up to $50^{\circ}$ to either south-west or north-east) at the south end of the section. The main cleavage is invariably steeper than inverted bedding throughout the section.

In order to test for continuity in structural geometry across the boundary between the Ben Ledi Grit and the Keltie Water Grit formations, stereographic projections of the main cleavage were prepared for the southern part of the Ben Ledi Grit outcrop (Figure 20, area A), the Transition Member (area B), and the northern part of the Keltie Water Grit outcrop (area C). These plots show that the mean orientation of the main cleavage in these three subareas is very similar and that it is not possible to separate the areas on the basis of structural geometry.

Harris (1969) recognized two main fabrics in these rocks, a penetrative slaty cleavage and a crenulation cleavage, which he correlated with similar structures in the adjoining Dalradian sequences. The crenulation cleavage is superimposed upon, and crenulates, the main cleavage described here and is most strongly developed in the argillaceous horizons such as the black slaty pelites above the waterfall at NN 6458 1247. The crenulation cleavage formed during a weak deformational event, which resulted in a gentle upright warping of beds in parts of the section. From a microscope study of the structural fabrics, Harris and Fettes (1972) subsequently identified an early cleavage in these rocks, which lies at a very low angle to bedding, and formed before the main cleavage. It is very difficult to see the early cleavage in the field.

The contact between the Keltie Water Grit Formation and the Lower Old Red Sandstone is seen as a fault at NN 6451 1221, first described in detail by Harris (1969). The fault plane dips at $54^{\circ}$ to the north-west (strike $048^{\circ}$ ) and is overlain by $40 \mathrm{~cm}$ of fault gouge and fragmented rock, followed by several metres of contorted and polished black slaty pelites. The exposed Old Red Sandstone succession commences with $5 \mathrm{~m}$ of conglomerate found in the stream bed immediately south of the fault, which is overlain by volcanic rocks dipping steeply to the south-east.

\subsection{Interpretation}

All previous workers, from Clough in 1897 to the present day, have agreed that the Ben Ledi Grit Formation and the overlying pale metasandstones and black slaty pelites of the Keltie Water Grit Formation form an essentially unbroken stratigraphical succession (i.e. Harris, 1962; Tanner, 1995). The transition beds, which occur between them, appear to be a normal stratigraphical part of the sequence and not to have arisen from tectonic interleaving. The rocks have all been affected by the same sequence of structural events, and are all at the same metamorphic grade (Tanner and 
Pringle, 1999). No evidence has been presented that contradicts any of these conclusions.

As has been demonstrated here, the main cleavage (S1) in the Keltie Water section maintains a consistent orientation and facing direction across the boundary between the Bed Ledi Grit and the Keltie Water Grit formations. Recent confirmation that there is evidence of a pre-D1 deformation phase in both the Bed Ledi Grit and the Keltie Water Grit formations, strengthens the structural correlation between these two units (Harris et al., 1998; Tanner, 1998b). It is extremely unlikely that two sets of structural fabrics, which have formed at relatively low strains (Figure 20 insets) and at low metamorphic grade, could have originated independently in two terranes of entirely different age and origin and then, upon amalgamation of the two terranes, become indistinguishable in their morphology, geometry, and facing direction. No alternative interpretation has been proposed to explain the structural data.

Recent work has also shown that that the metasandstones in the sequence have many petrographical features in common, despite the fact that burial diagenesis has almost certainly altered all of the detrital plagioclase to nearly pure albite $\left(\mathrm{An}_{1-3}\right)$, and caused dissolution of any pre-existing K-feldspar (Figure 21). The results of a whole-rock geochemical study of these metasandstones are consistent with the conclusion reached from the petrography, that the main vertical changes in composition reflect a progressive upward decline in amounts of detrital plagioclase and biotite (Tanner and Pringle, 1999). In addition, electron-microprobe analysis of the detrital white micas from these rocks has shown that they have a comparable range in $\mathrm{Si}, \mathrm{Fe}, \mathrm{Mg}$, and $\mathrm{Ti}$ contents at all levels of the sequence, with more-sodic micas occurring in the Transition Member and younger rocks. The wide range in chemistry suggests that they were derived from a complex source region.

${ }^{40} \mathrm{Ar} /{ }^{39} \mathrm{Ar}$ laser fusion ages on detrital white micas from metasandstones at five different levels in the sequence gave age spectra which show a gradation from all old mica ages in the Ben Ledi Grit Formation (mainly 1600-1800 Ma, with a few at $2100 \mathrm{Ma}$ ) to a mixed population of old and younger white micas (507-886 Ma) in the Keltie Water Grit Formation. This work shows that none of the mica ages has been reset by Caledonian regional metamorphism, agreeing with the results of the petrographical work that the regional metamorphism was of low greenschist facies throughout, with no detectable metamorphic breaks, and maximum temperatures probably not exceeding $270^{\circ} \mathrm{C}$.

The reported differences in whole-rock geochemistry, detrital mica composition and ${ }^{40} \mathrm{Ar} /{ }^{39} \mathrm{Ar}$ age upward in the succession are, as far as can be determined, progressive. Some of these changes may be linked to the establishment of a stable shelf environment, with the incoming upwards from the Ben Ledi Grits to the top of the Keltie Water Grit Formation of black muds, dark limestones, and dolostones, and an increase in the amount of possible detrital carbonate minerals in the turbidites (Tanner and Pringle, 1999). These data do not however preclude the possibility that an intraformational break may be present somewhere in the sequence. 
The most illuminating finding from these investigations is that there is no suggestion from either the field observations or the various analytical data, of a major stratigraphical/structural break at a single, discrete level within the sequence that might be taken as positive evidence for the presence of a terrane boundary. Such a terrane boundary, if it existed, would have to be located between the southernmost exposure of undoubted Dalradian rocks (Ben Ledi Grit Formation), belonging to the Grampian Terrane, and the rocks farther south which include the Leny Limestone and were once considered to belong to an exotic terrane (the Highland Border Complex), which collided with the Grampian Terrane in late-Silurian to Devonian times (Brasier et al., 1992; Bluck and Ingham, 1997). In view of the conclusion supported here that the rocks from the undoubted Dalradian Supergroup to the top of the Keltie Water Grit Formation are in their original stratigraphical sequence, this latter formation should be included logically within the Dalradian Supergroup. It is the lowest formation in the proposed Trossachs Group of Tanner and Sutherland (2007), which would include all units of the Highland Border Complex that crop out structurally below (i.e. north-west of) the Highland Border Ophiolite. This new Dalradian group would include strata containing fossils as young as Arenig in age.

It follows from the above relationships that the upper part of the Dalradian succession must have been deposited between $646 \mathrm{Ma}$ (the youngest reliable detrital white mica age in the Keltie water sequence and $c$. 517-509 Ma (the probable age range of upper Lower Cambrian rocks such as the trilobite-bearing Leny Limestone; Davidek et al., 1998). This conclusion is compatible with the U-Pb age on zircon of $595 \pm 4$ Ma for the Tayvallich Volcanic Formation, which lies near the top of the Argyll Group (Halliday et al. 1989), and with the $590 \pm 2$ Ma age for the Ben Vuirich Granite (Rogers et al. 1989; Dempster et al., 2002), which hornfelsed previously undeformed Dalradian rocks prior to the Grampian Event (Tanner and Leslie, 1994; Tanner, 1996; Tanner et al., 2006).

In conclusion, as all of the rocks at this site can be shown to have shared the same structural history, then the Grampian Event where it affects the Southern Highland Group, is of post-Early Cambrian age (i.e. post $509 \mathrm{Ma}$ ). The Tay Nappe deformations (regional D1 and D2), and a possible earlier episode of deformation (Harris et al., 1998; Tanner, 1998b) are also therefore of postCambrian age.

\subsection{Conclusions}

The Keltie Water provides a unique section of national importance through the uppermost Dalradian strata exposed in the Highland Border region. Its importance lies in the fact that it is the only place in the Grampian Terrane where there is an exposed section linking undoubted Dalradian rocks with fossiliferous rocks of known biostratigraphical age. Trilobites of Early Cambrian age have been reported from the Leny Limestone, which occurs at the nearby Leny Quarry GCR site (Rushton et al., 1999). As the Dalradian rocks were once thought to be much older than this, the stratigraphical and structural relationship between undoubted Dalradian rocks and 
strata in the Keltie water that are correlated with the Cambrian rocks at Leny Quarry, has excited much scientific interest. Accordingly, the geological relationships seen at this GCR site have been the subject of much research and rigorous scientific debate in the past few decades.

Most geologists who have studied this GCR site now conclude that there is stratigraphical and structural continuity within the Keltie Water section, and a corresponding lack of evidence for a postulated terrane boundary between the undoubted Dalradian and the Cambrian rocks. The important corollary to this is that the Grampian Event, where it affects the upper part of the Dalradian sequence, commenced after the Early Cambrian, and that there is no evidence to support the hypothesis that a prior Precambrian orogenic event had affected the Dalradian rocks.

\section{8}

\section{LITTLE GLEN SHEE \\ (NN 979 346) \\ CRAIG A'BARNS \\ (NO $019 \quad 438-$ NO $014 \quad 442$ ) \\ ROTMELL \\ (NO $014 \quad 469-$ NO $011 \quad 475$ )}

\section{A.I. Harris}

\subsection{Introduction}

The Little Glen Shee, Craig a'Barns and Rotmell GCR sites, in the Dunkeld area of the Highland Border, collectively display the essential features of the structure, sedimentology and metamorphism of the Perthshire outcrop of the Southern Highland Group. In order to fully appreciate the overall geological situation, it is necessary to combine observations and deductions from all three sites (Figure 23). Consequently this site report consists of a general introduction, detailed descriptions of the three individual sites, an overall interpretation and combined conclusions.

The three sites, which are in fairly close geographical proximity, were selected particularly to demonstrate the increasing structural complexity and increasing metamorphic grade with tectonic depth in the Tay Nappe, the major recumbent anticlinal nappe fold of the South-eastern Grampian Highlands (Figure 24). All three occur in the inverted lower limb of the nappe, which extends across strike almost from the Highland Border to the NE-trending Tummel steep Belt, some $17 \mathrm{~km}$ to the north-west (Figures 23 and 24a). Over much of its extent, the lower limb is not only inverted, but is regionally subhorizontal, comprising the Flat Belt. However, to the south-east of the Flat Belt, the flat-lying inverted rocks have been bent down through as much as $120^{\circ}$, across the hinge of a late, regional-scale, NE-trending asymmetrical antiform, the Highland Border Downbend. On the south-east limb of this fold, the formerly flat-lying rocks now dip steeply (c. 60\%) to the north-west, and 
thus are generally the right way-up (Figures 23 and 24). These rocks constitute the Highland Border Steep Belt (Harris et al., 1976). Thus, the sites have been chosen to represent rocks low in the Highland Border Steep Belt (Little Glen Shee), rocks high in the Highland Border steep Belt and lying in the hinge-zone of the Highland Border Downbend (Craig a'Barns) and in the Flat Belt (Rotmell).

The detailed structural geology of the area containing these three GCR sites has been described and discussed by stringer (1957), Shackleton (1958) and Harris et al. (1976); some of the tectonic structures and fabrics discussed here were illustrated and described by Bradbury and Harris (1982). Rose and Harris (2000), working to the south-west of these GCR sites, distinguished two zones within the Highland Border Steep Belt, which they termed A and $B$. The exposures comprising the Little Glen shee GCR site relate to their Zone A, while many of the features of Zone $B$ are displayed in the south-eastern part of the Craig a'Barns site. The transition from Zone A to Zone B is not exposed in this area.

The rocks of all three GCR sites comprise interbedded metasandstones and metasiltstones, stratigraphically assigned to the Southern Highland Group (Harris et al., 1994). In the Dunkeld area, three units were proposed by Harris (1972): the Birnam Grit (oldest; base not seen), the Birnam Slate, and the Dunkeld Grit (youngest; top not defined). Elsewhere, the lower two units have been combined into a single Birnam Slate and Grit Formation, reflecting a more-complex stratigraphical distribution of the two sedimentary facies (Crane et al., 2002). The depositional environment of the original clastic sediments, mainly comprising poorly sorted turbiditic sands with minor silty beds, was discussed by Harris et al. (1978) and Anderton (1985), who concluded that the coarse-grained clastic deposits were laid down in channels on the lower slopes and inner zones of deep-water submarine fans, with the finer grained sediments being laid down as overbank deposits or in outerfan facies. Lateral continuity of any one facies is therefore unlikely and, even where traceable over short distances, probably has little chronostratigraphical significance. Hence conclusions about the relative ages of the rocks at the three GCR sites are tentative and are based on structural considerations (see Interpretation).

The cross-sections in Figure 24 show the relative structural positions of the three GCR sites; Little Glen Shee originally lay at a higher level in the nappe than Craig a'Barns and Rotmell, both of which lie at a similar level. The Little Glen shee site illustrates the earliest deformation which, in addition to producing folds of bedding, induced a cleavage in the rocks that takes the form of a slaty cleavage in the metasiltstones and a pressure-solution striping (S1P) in the metasandstones. Subsequent deformation episodes modified the S1p; that associated with the second deformation (D2) modified the original planar striping into F2 folds having thick hinges but highly attenuated limbs. F2 folds, which predominate in the Flat Belt, are seen in their original attitude at the Rotmell GCR site. They have been bent down around the Highland Border Downbend at the Craig a'Barns site and there they are seen to be overprinted by the downbend-related 
structures and fabrics. Although the rocks of the Little Glen shee site lay initially at a higher level in the Tay Nappe than those at either Craig a'Barns or Rotmell, they were bent down by the Highland Border Downbend so that their original stratigraphical/structural configuration has been changed and their cleavage and folds now face downwards. The Little Glen Shee GCR site therefore exemplifies the concept of 'downward facing' on first cleavage that was first developed by Shackleton (1958) in the Highland Border region (see Stephenson et al., 2013a, p. 32).

The three GCR sites also illustrate the variation in the metamorphic grade of the Southern Highland Group in the Highland Border region of Perthshire. Metasiltstones at Little Glen shee are chloritic slates, whereas at craig a'Barns they are phyllites typically containing chlorite and white mica with some biotite. Metasiltstones at Rotmell carry conspicuous euhedral, almandine garnets. While structural complexity and tectonic strain at craig a'Barns are comparable with those at Rotmell, and are considerably greater than at Little Glen shee, the metamorphic grade at Rotmell appears to be notably higher.

\subsection{Description}

\subsubsection{Little Glen Shee GCR Site}

Little Glen Shee intersects the Highland Border between the rivers Almond and Tay, some $15 \mathrm{~km}$ north-west of Perth. The GCR site is located some $450 \mathrm{~m}$ along the track leading north-west from Little Glen Shee farm. It was chosen as an excellent example of the sedimentary and tectonic features of the weakly deformed and metamorphosed Southern Highland Group rocks occurring originally at a high level of the Tay Nappe, but subsequently bent down to a lower structural level by the Highland Border Downbend.

The rocks described here form a large crag to the north-east of the track, about $100 \mathrm{~m}$ north of a large $(4 \mathrm{~m} \times 1.5 \mathrm{~m})$ boulder (Figure 25).

The metasedimentary rocks probably belong to the Birnam Slate and Grit Formation and consist of well-defined beds of poorly sorted, matrix-supported coarse- to medium-grained metasandstone wackes that grade upwards, usually passing by rapid transition into finegrained metasandstones and mica-rich metasiltstones. Such graded beds are up to $0.5 \mathrm{~m}$ thick and the grading is well picked out by cleavage refraction (Figure 25, insets 1 and 2; Figure 26a). There are abundant subangular clasts of quartz and feldspar up to $2 \mathrm{~mm}$ across in the coarser fraction. Some of the metasandstone beds are composite and are inferred to have been deposited by more than one turbidity current. Bedding lamination (Figure 25, insets 1 and 2; Figure 26b) and more-rarely small-scale cross-lamination are commonly well displayed in the medium- to fine-grained metasandstones. Where seen, the younging indicated by the crosslamination is consistent with that shown by the graded bedding.

The beds have been folded into a pair of modified buckles, having rounded hinges, straight limbs, interlimb angles of $C .70^{\circ}$ and wavelengths of c. $7 \mathrm{~m}$ (Figure 25). Parasitic on these, a smaller 
pair of modified buckles have wavelengths of c. $1 \mathrm{~m}$ (Figure 26b), and minor folds having wavelengths of 3-4 $\mathrm{cm}$ are developed in their core. Sedimentary structures all young unequivocally towards the cores of the antiforms and away from the cores of synforms, so that successively younger beds are encountered as axial planes are traced downwards. Hence, the folds face downwards.

In addition to the folding of the sedimentary layers, the D1 deformation imposed a cleavage which takes two distinct forms that are lithologically dependent: (1) a pressure-solution cleavage in the metasandstones (S1p of Harris et al., 1976); and (2) a slaty cleavage in the metasiltstones (S1).

The S1p cleavage is confined to the metasandstone layers towards the base of each graded bed and comprises well-defined planes, normally orientated at a high angle to bedding. These planes, which are spaced at intervals of $c .1 \mathrm{~cm}$, coalesce and ramify in detail, both laterally and normal to bedding such that the rock between the planes is rendered into lenticles, commonly referred to as 'microlithons'. Close examination of the planes of Slp shows that they comprise, not planes, but narrow zones (less than $1 \mathrm{~mm}$ wide) largely made up of micaceous material. The abundant mica in these zones results in their differential weathering, leaving the centimetre-scale siliceous lenticles standing conspicuously proud of the weathered surface. Hence the orientation pattern of the S1p laminae can be readily picked out and it is easy to see that it fans through as much as $100^{\circ}$ and that it is approximately symmetrical about the fold axial planes. Fanning is a feature of the S1p in Figure 26b.

During the process of deformation and the formation of S1p, considerable re-orientation of primary bedding features within the sandstone layers evidently took place. This becomes apparent where the orientation of bedding lamination within the cleavage domains $\left(\mathrm{SO}_{\text {lam }}\right)$, is compared with the orientation of gross bedding (SO); $\mathrm{SO}_{\text {lam }}$ is commonly $45^{\circ}$ or more, oblique to $\mathrm{s} 0$, particularly on the inverted SSE-younging limbs (Figure 25). Within-bed re-orientation of cleavage is also displayed locally, although it probably occurred entirely later than the formation of SIp. In some beds, Slp has been buckled sufficiently to face upwards and downwards within the same bed without the bed itself being apparently folded.

S1 refers to the penetrative axial-planar slaty cleavage that occurs in the finer grained original tops of the graded beds. In thin section this cleavage is seen to be defined by aligned white mica and chlorite, and by quartz and feldspar having a preferred dimensional orientation. $\mathrm{SI}$ is oblique to SIp except in the fold cores where it is approximately parallel. Elsewhere slp refracts into the plane of $\mathrm{Sl}$, the curving surface associated with the change in orientation clearly indicating the narrow zone within each bed where the decrease in original grain size from sand to silt occurs. By contrast, the contact between the coarse-grained base of each bed and the fine-grained top of the bed immediately below it is emphasised by the sharp angular break between the S1 in the older bed and the S1p in the younger bed. (Figure 26b).

D2 and Highland Border Downbend-related structures are not developed at this site. 


\subsubsection{Craig a'Barns GCR Site}

The Craig a'Barns GCR site lies within an area of steep crags, several of which are popular rock-climbing venues, in an area of woodland about $1 \mathrm{~km}$ north-west of Dunkeld. The site has been chosen to represent rocks at a relatively high structural level in the Highland Border Steep Belt and in the hinge-zone of the Highland Border Downbend. The cross-sections in Figure 24 show that the rocks at Craig a'Barns originally lay at a similar level in the Tay Nappe to those at Rotmell, but the bedding and the F2 folds, which predominate in the Flat Belt, have been bent down around the Highland Border Downbend and are seen to be overprinted by the downbend-related structures and fabrics. While structural complexity and tectonic strain at Craig a'Barns are comparable with those at Rotmell and are considerably greater than at Little Glen Shee, the metamorphic grade is not as high as at Rotmell.

The rocks at the site are probably among the youngest Dalradian rocks exposed in the Dunkeld area, and are assigned to the Dunkeld Grit Formation. They are described in a traverse through several key localities across the Highland Border Downbend, from the steep south-east limb through the hinge-zone to the gently inclined north-west limb (Figures 23 and 24). The localities are shown on Figure 27. The F1 folds exposed at the Little Glen shee GCR site have not been observed here, the dominant structures being F2 folds of the S1 and S1p cleavages as well as D4 structures associated with the Highland Border Downbend. The rocks are metamorphosed sandstones and mudstones, but convincing way-up indicators have not been found. The rocks are in the greenschist facies of Barrovian metamorphism, so that the metasiltstones are phyllitic and typically containing chlorite and white mica with some biotite. Minute spessartine-rich almandine garnets occur in laminae between pressure-solution cleavage planes (S1p) within the metasandstones (M.P. Atherton, personal communication, 2000).

Locality A (NO 0194 4378) is a cliff face some $18 \mathrm{~m}$ high, above a short, boulder-strewn slope. On this face, a fold-pair on the scale of the crag is defined by a 2 m-thick metasandstone bed. The long limbs of the fold-pair dip at $60^{\circ}-70^{\circ}$ to the north-west and the short limb dips gently to the south-east. This fold-pair is parasitic on the south-east limb of the Highland Border Downbend and indicates that the main hinge lies to the north-west. Smallscale open folds of 2-3 cm wavelength, associated with a weakly developed crenulation cleavage dipping at moderate angles to the north-west, are inferred to be downbend-related structures.

The early cleavages, SIP and S1, lie subparallel but at a discernible angle to bedding; the millimetre-scale spacing of the Slp planes shows that the intervening microlithons are considerably attenuated in comparison with those seen at the Little Glen shee GCR site. Both cleavages are affected locally by D2 structures. F2 fold wavelengths are on a centimetre to decimetre scale with interlimb angles from $60^{\circ}$ to isoclinal; hinges are curvilinear about the horizontal and vergence is to the north-west. S2 cleavage is axial planar to F2 folds, whose axial surface traces are also subparallel to bedding. 
Locality B (NO 0183 4389) consists of vertical to overhanging crags. Although the crags display interference between $F 2$ and Highland Border Downbend-related folds and overprinting of S1, S1p and S2 by downbend-related crenulations and minor folds, this locality is most remarkable for its display, in microcosm, of the essential relationships of the Highland Border Downbend. Up a natural "step", about $1 \mathrm{~m}$ high, in the base of the crag, a $1 \mathrm{~m}^{3}$ exposure of metasandstone displays a smooth planar surface defined by bedding and S1p that has been bent down to the south-east around a smooth open asymmetrical antiform from a subhorizontal into a subvertical attitude. This NE-trending, small-scale antiform is inferred to be parasitic on the south-east limb of the Highland Border Downbend. A well-defined shape-fabric lineation, contained within the folded planar surface, trends approximately $\mathrm{N}-\mathrm{S}$ on the flat top surface of the fold and is also bent down across the antiform hinge to plunge steeply to the south-west in its steep limb. Figure $28 \mathrm{a}$ shows a subvertical cross-section of the antiform, illustrating the nature, attitude and sense of overturning of F2 folds on both its subvertical and subhorizontal limbs and the folding and downbending of $\mathrm{Slp}$. The spacing of the S1p cleavage has been severely attenuated by D2 (see Interpretation). Adjacent metasiltstones show the NW-dipping downbend-related crenulation cleavage to be approximately axial planar to the antiform.

Locality $C$ consists of crags that lie in the hinge-zone of the Highland Border Downbend. In particular the first crag reached to the north of the path (NO 0175 4387), probably lies very near to the downbend hinge-zone. It displays, in micaceous lithologies, a very strongly developed crenulation cleavage dipping generally to the north-north-west at $45^{\circ}-50^{\circ}$, but variable up to $60^{\circ}-70^{\circ}$ (Figure 28b); this is inferred to mark the attitude of the downbend axial surface. The crenulation cleavage is axial planar to ENE-trending open parasitic folds in the hinge-zone of the downbend (Figure 28c). At the top of the exposure illustrated in Figure 28c, bedding is essentially parallel to both $\mathrm{S} 1$ and $\mathrm{S} 2$ but in the bottom left, S1p is at a distinct angle to bedding. Tight F2 folds of S1p (not seen in Figure 28c), having highly attenuated limbs, lie with their axial surfaces at variable, but high, angles to the inferred downbend axial surface.

The main path, running up a glacial meltwater channel, reaches a deer fence at (NO 014 442) passing on the way numerous crags above it on the right (north-east). All of these crags lie within the Flat Belt but the two nearest to the fence (locality D, NO 0149 4411) are the most rewarding. Gross bedding, defined by metasandstone - metasiltstone interlayering, and SIp are generally flat lying or gently inclined but are bent locally into a steep attitude to form the intermediate limb of a Z-shaped (looking north-east) fold-pair. These folds, which are on a scale of metres to decimetres, indicate an asymmetrical antiform to the south-east, i.e. the Highland Border Downbend, although their hinge-zones are transected by the NW-dipping crenulation cleavage also related to the downbend (see Interpretation). 


\subsubsection{Rotmell GCR Site}

Rotmell Farm is adjacent to the A9 trunk road and 4-5 $\mathrm{km}$ northnorth-west of Dunkeld. The Rotmell GCR site is a series of small exposures within a rectangle of open heather-clad rocky hillside above the farm, measuring some $700 \mathrm{~m} \times 200 \mathrm{~m}$ and elongated almost precisely north-west - south-east. The site has been chosen to represent the lower, inverted limb of the Tay Nappe in the regionally subhorizontal Flat Belt, to the north of and unaffected by the Highland Border Downbend.

The rocks at the site could be assigned to either the Dunkeld Grit Formation or to the stratigraphically lower Pitlochry Schist Formation (see Interpretation). The cross-sections in Figure 24 show that they occur at a similar stratigraphical level to those of the Craig a'Barns site and that they originally lay at a similar structural level in the Tay Nappe. At this level, the original planar striping (S1P) generated during the first deformation episode (D1), has been modified during the second deformation (D2). F2 folds having thick hinges but highly attenuated limbs, which predominate in the Flat Belt, are seen in their original flat-lying attitude at Rotmell. While the structural complexity and tectonic strain at Rotmell are comparable with those at Craig a'Barns, the metamorphic grade at Rotmell appears notably higher.

The solid geology comprises metasandstones interbedded with subsidiary metasiltstones and metamudstones, now quartz-mica schists and garnet-mica schists. Locally the metasandstones are notably pebbly, containing granules of less than $5 \mathrm{~mm}$ diameter. These rocks, which are more highly metamorphosed than those at locality $\mathrm{D}$ at Craig a'Barns, some 3-4 $\mathrm{km}$ to the south, are typical of the Southern Highland Group at moderate metamorphic grade. The rocks are inferred to be inverted, but convincing direct evidence from sedimentary structures is lacking at this site.

Conspicuous in the metasandstones are centimetre- to metre-scale zones, in which thin seams between the early pressure-solution cleavage planes (S1p) are affected by F2 folding. The centimetrescale, NE-trending, F2 folds occur in pairs or even-numbered multiples and the seams are notably thinner on the limbs than in the hinges (Figure 29). The zones containing folds are commonly separated from one another by zones lacking folds but in which the Slp seams are strongly attenuated. The folds are almost invariably overturned and are stacked in such a manner as to suggest that they are parasitic on a recumbent fold, the axial surface of which lies above the present erosion surface and closes to the south. F1 folds and angular relationships between bedding (SO) and S1 cleavages have not been observed. Marked lineations, similar to those described from locality $B$ at the Craig a'Barns GCR site, comprise grain-shape and quartz rodding, and are approximately north-trending on flat-lying foliation surfaces formed by composite S1 and S2 cleavages. Together the lineations and foliation define an LS fabric, the lineation representing the finite extension direction related to D2. This is well displayed at NO 14964703.

The metasiltstone layers in particular carry subhedral to euhedral, spessartine-poor almandine garnets up to $0.5 \mathrm{~cm}$ in diameter. Close examination of these with a hand lens shows that 
individual garnets contain an internal planar fabric defined by relict inclusions, a pre-garnet foliation (?S1), while the garnet crystals themselves are wrapped by the conspicuous mica-defined foliation in their matrix (composite S1/S2). S1/S2 itself is crenulated by small-scale folds the axial surfaces of which dip north-west at $c .30^{\circ}$ with the development of an incipient crenulation cleavage. This modification of the fabric may well be related to the Highland Border Downbend episode of deformation (D4). Excellent examples of these relationships may be seen at NO 0122 4734, about $70 \mathrm{~m}$ north-west of a solitary, conspicuous beech tree.

\subsection{Interpretation}

The Little Glen Shee, Craig a'Barns and Rotmell GCR sites complement one another and together are important to our understanding of: 1) the mechanisms of deformation and regional metamorphism, including pressure solution, that accompany the development of a major nappe, in this case the Tay Nappe, from its earliest stages to its transport and emplacement; and 2) the geological history of the Scottish Highlands and the timing of events in the Scottish sector of the Caledonide /Appalachian Orogen.

The turbiditic environment in which the sediments of these three GCR sites were deposited makes the relative ages of the rocks and the stratigraphical correlation between them difficult. Regional structural and stratigraphical relationships strongly suggest that the rocks at Little Glen Shee might lie some 2-3 $\mathrm{km}$ stratigraphically below the Craig a'Barns strata (Harris, 1972; Harris and Fettes 1972). The rocks at Little Glen shee lie in the Birnam Slate and Grit Formation, which is older than the Dunkeld Grit Formation of the Craig a'Barns site, which probably includes the youngest Dalradian rocks exposed in the area. However, there is ambiguity in assigning the rocks at Rotmell to a lithostratigraphical unit. The gentle overall dip to the northwest of the rocks on the north side of the Craig a'Barns site suggests that the inverted strata there are likely to pass below those at Rotmell, which are also inferred to be inverted. If so, the rocks at Rotmell are slightly older than those at craig a'Barns. The high metamorphic grade of the rocks at Rotmell, indicated by the coarse grain size and the conspicuous garnet also lends them obvious affinity to the Pitlochry Schist Formation of the area to the north. Defining a boundary between the Pitlochry Schist and the Dunkeld Grit formations, however, has never been attempted. The differences between them are probably due as much to secondary effects, such as metamorphic grade and intensity of pressure solution, as to any primary contrasts in the protolith.

The Highland Border Downbend, an asymmetrical, overturned open antiform, has as its steep south-east limb a zone of steeply NWdipping, right-way-up rocks that, pre-downbend, were flat-lying and inverted on the lower limb of the nappe (Figure 24). These steeply dipping strata now crop out between the axial surface trace of the Highland Border Downbend and the Highland Boundary Fault. Consequently, a horizontal traverse from south-east to north-west across the zone is equivalent to a vertical section from high to 
lower levels of the nappe. Excellent examples of the contrasting phenomena typical of each level are displayed by the Little Glen Shee and the Craig a'Barns GCR sites respectively. Thus insights into the significant changes in the conditions of temperature and pressure (confining and directed) that took place with increasing depth in the nappe can be obtained by comparing these two sites. The Little Glen Shee site offers opportunities to view and interpret the effects of the earlier stages in nappe development (D1), unobscured by the overprinting of the D2 fabrics resulting from the transport and emplacement of the nappe (as seen at the Craig a'Barns and Rotmell GCR sites). North-west of the axial surface trace of the Highland Border Downbend the lower, inverted limb of the nappe is essentially at the same structural level as the Craig a'Barns site over the c. $17 \mathrm{~km}$ of gently undulating rocks that lie between the downbend and the Tummel Steep Belt (Figures 23 and 24). These are represented by the Rotmell GCR site, where the rocks are in their post-D2, pre-downbend attitude. Rotmell thus complements Craig a'Barns because, although significantly higher in metamorphic grade, the fabrics in the rocks here relate only to D1 and D2 and were not complicated by the post-D2 overprint of fabrics related to the Highland Border Downbend. The post-D2 fabrics are largely confined to the axial zone of the downbend and can be correlated broadly with the regional D4 phase.

The F2 folds that are a feature of the Craig a'Barns and Rotmell sites have been related by Harris et al. (1976) and Rose and Harris (2000) to SE-directed shear that contributed to the emplacement of the Tay Nappe. These sites thus offer important insights into the mechanisms of nappe emplacement in general and the Tay Nappe in particular (but see also the Duke's Pass GCR site report for an alternative interpretation). The thinned 'limbs' of the F2 folds are interpreted here as top-to-the-SE shear-zones (involving largely simple-shear) whereas the 'hinges' are zones in which D2 strain is low. The thin micaceous seams that comprise the conspicuously folded laminae at Craig a'Barns and Rotmell originated by pressure solution as the Slp cleavage. In its pristine state, this cleavage can be studied at Little Glen shee, where the Slp seams normally lie at a high angle to bedding $\left(60^{\circ-}\right.$ $\left.90^{\circ}\right)$. At the Craig $a^{\prime}$ Barns and Rotmell GCR sites, the angle between bedding and S1p, albeit small as a result of D2 strain, is still discernable, as is their original ramifying and coalescing primary pattern of intersection. Consequently, it is concluded that, at an early stage of deformation (D1), tectonically induced pressure solution produced a lithological lamination in the rocks that was not related to primary bedding and that this lamination was subsequently deformed as the D2 emplacement of the nappe proceeded. The emplacement and transport of the nappe by the D2 structures might only have become possible as increased metamorphic grade, rising through the nappe with time, permitted the formation of the ductile shear-zones that comprise the F2 fold limbs. If so there was likely to have been a strong element of diachroneity in the imposition of both the D1 and D2 structures.

Tentative, but important and regionally significant conclusions about the pattern and timing of regional metamorphism can be drawn from the combined evidence at the three GCR sites. It seems likely 
from the evidence at the Rotmell site that the peak of metamorphism post-dated the fabrics included in the garnets and pre-dated the crumpling of the composite S1/S2 schistosity during the deformation that produced the Highland Border Downbend (D4). One could conclude from these relationships that the isograds reflecting the pressure and temperature patterns at the regional metamorphic peak were essentially established before the imposition of the downbend and that the isograd surfaces were bent down to the south-east into the Highland Border steep Belt with the earlier tectonic structures. This would account for the rise in metamorphic grade from Little Glen shee to Craig a'Barns. The contrast in grade between these two sites could be explained by isograds dipping generally south-eastwards slightly more steeply than the subhorizontal to gently inclined bedding/foliation planes in the inverted limb of the nappe. This interpretation would be consistent with the metamorphic grade at Rotmell being intermediate between that at Craig a'Barns and that of the kyanite-bearing migmatitic pelites of the Ben Lui and Pitlochry Schist formations to the north.

A general conclusion that can be drawn from these three GCR sites, taken collectively, is that the intensity of deformation and metamorphism is independent of age in rocks as complex as those described. The oldest rocks, i.e. those from Little Glen shee, are the least deformed and metamorphosed of the three sites. However, without their comparative simplicity, explicit facing and younging characteristics and well-developed pressure-solution cleavage, interpretation of the other two sites would be more difficult and uncertain than is the case.

The sets of folds and fabrics described and interpreted above are widely recognized and correlated throughout the south-eastern Grampian Highlands. The first and second sets have been demonstrated by Rose and Harris (2000) to be the result of an essentially continuous process of early deformation producing upright folds and pressure-solution cleavage, passing into recumbent folds as the former were deformed and transported to the south-south-east on D2 shear-zones. This continuity is important in interpreting the age of orogenesis in the Grampian Terrane. The earliest cleavages overprint the Keltie Water Grit Formation of the Callander district, which includes the Lower Cambrian Leny Limestone (Tanner, 1995; Harris et al., 1998; see the Keltie Water GCR site report) and hence must be younger than the radiometrically dated Ben Vuirich Granite (590 \pm 2 Ma; Rogers et al., 1989) that had formerly been used to indicate the minimum age of the orogenesis (see the Ben Vuirich GCR site report). The conclusion that the earliest fabrics post-date Cambrian rocks means that the orogenesis was Early Palaeozoic in age, probably mid Ordovician, rather than Neoproterozoic, as was believed formerly.

\subsection{Conclusions}

The Little Glen Shee, Craig a'Barns and Rotmell GCR sites together display the best set of exposures in the British Isles to exhibit the sequence of structures developed during the initiation, emplacement and modification of a major recumbent fold (nappe). 
This fold, the Tay Nappe, is one of the largest and most significant major structures in the whole of the Grampian Terrane, and indeed in the whole of Great Britain. The sites also show typical examples of the primary sedimentary and subsequent metamorphic characteristics of the rocks that comprise the Southern Highland Group.

Relative to the other two GCR sites in this area, the rocks of the Little Glen Shee site originated at the highest level in the Tay Nappe and are at the lowest metamorphic grade. They display exceptionally well-preserved sedimentary structures, especially the graded bedding that results from the rapid deposition of coarse sands in a turbiditic deep-water environment. They also display unusually clear examples of the first generation of folds, together with their steeply dipping axial-planar cleavage, which in the coarser grained rocks takes the form of a widely spaced pressuresolution cleavage. The bedding/cleavage relationships, together with the sedimentary structures, show quite dramatically at this site that the folds are totally inverted; this was the classic area where Shackleton (1958) first developed the concept of structural 'facing', now an internationally accepted term. These folds are thus 'downward-facing', the explanation for which requires examination of the Craig a'Barns GCR site.

The rocks of the Craig a'Barns GCR site once occupied deeper levels of the Tay Nappe than those of the Little Glen shee site. Consequently, the original sedimentary bedding characteristics, and the small-scale folds and cleavages that formed during the initial stage of nappe formation, have all been considerably modified by a second generation of small-scale structures, both folds and cleavage, which relate to subsequent development of the nappe. The site also contains possibly unique exposures of the hinge of a later major fold, the Highland Border Downbend, which was responsible for the rotation of the original flat-lying rocks, exemplified in the Rotmell GCR site, into the steep-dipping downward-facing attitude, seen in the Little Glen Shee GCR site.

At the Rotmell GCR site it can be clearly seen that the cleavage related to the first generation structures, as seen at the Little Glen Shee GCR site, has been strongly modified by a second deformation. It has been suggested that the second generation of small-scale structures, both folds and cleavage, are a result of the transport and emplacement of the Tay Nappe. Originally upwardfacing first structures are believed to have been translated many kilometres to the south-east, and modified by the second deformation, so that much of the Southern Highland Group, such as that in the Rotmell GCR site, lies in the inverted limb of the resulting sideways-facing fold. Rocks in the Rotmell GCR site contain crystals of garnet, which are evidence of relatively deep burial, but rocks originally at a higher level in the nappe and subsequently bent down, such as those now exposed at the Little Glen Shee GCR site, exhibit a much lower grade of metamorphism. 


\title{
9 GLEN ESK \\ (NO $586733-$ NO $583736,579744,583756,574766,560$ 785)
}

\author{
D. Gould and B. Harte
}

\subsection{Introduction}

The valley of the River North Esk in the Angus Glens is in the heart of the area where George Barrow first demonstrated the development of successive mineral assemblages during the progressive regional metamorphism of pelitic rocks (Barrow, 1893, 1912). Here, the transition from low to high metamorphic grade can be studied over a distance of a few kilometres and the GCR site comprises six localities, one for each metamorphic zone, selected largely on grounds of ease of access (Figure 30). These localities, together with alternatives for some of the zones, were described by Harte (1987) .

While working for the Geological survey in this area, Barrow was the first person to define a scheme of indicator minerals for different degrees of regional metamorphism in pelitic rocks. He initially defined seven zones: the lowest grades were 'clastic mica' and then 'digested clastic mica', and up grade of these were zones defined by the progressive incoming of biotite, garnet, staurolite, kyanite and sillimanite. Tilley (1925) combined the two lowest grades into a single chlorite zone, since the distinction between clastic and non-clastic white micas was doubtful. Hence we now recognize six zones ranging from chlorite to sillimanite (Figure 31). This scheme, known as the Barrovian scheme, was found to apply to large areas of the Dalradian outcrop, and has been recognized in many other regional metamorphic terranes worldwide. In terms of overall metamorphic facies, it corresponds to a relatively high-pressure part of the greenschist and amphibolite facies.

However, in the area north of the River Dee and east of the Portsoy Shear-zone, a different sequence of metamorphic zones is developed. This, the Buchan scheme of Read (1955), corresponds to lower pressures over the same range of temperatures (see Stephenson et al., 2013b). A transitional zonal sequence between the two regimes is exposed on the coast north of Stonehaven (Harte and Hudson, 1979) (see the Garron Point to Muchalls GCR site report).

Barrow's original zonal scheme has stood the test of time, although Chinner (1966) regarded the development of fibrolitic sillimanite as a later thermal 'overprint' upon both the Barrovian and the Buchan zones. However, Harte and Johnson (1969) used thin sections to date the development of the metamorphic fabric of the rocks with respect to the various fold episodes in the district. They showed that prograde metamorphism continued longer in the higher grade rocks than in the lower grade rocks, and that the post-D3 crystallization of sillimanite, although overstepping the lower grade zones in places, was the culmination of a single long period of prograde metamorphism. Retrogression was associated with D4 and later movements. 
Also in this area, Atherton and Brotherton (1972) showed that the first appearance of kyanite in regionally metamorphosed pelites and semipelites is controlled by the effective $\mathrm{Mg} / \mathrm{Fe}^{2+}$ ratio of the rock. Harte and Hudson (1979) used petrological and geochemical methods to attempt to quantify pressures and temperatures at various stages in the metamorphic history of the eastern Grampian Highlands.

Field excursions that visit this GCR site have been described by Harte (1987) and MacGregor (1996).

\subsection{Description}

The first three localities are along the banks of the River North Esk; the others are on crags away from the river (Figure 30).

9.2.1 Locality 1, Chlorite Zone: North Esk Gorge (NO 586733 )

The North Esk Fault at this locality separates Dalradian rocks to the north-west from Highland Border Complex rocks to the southeast. The Dalradian rocks consist of compositionally layered, grey-green schistose chlorite-muscovite pelites, semipelites and psammites. Porphyroblasts of magnetite and rare pyrite up to $2 \mathrm{~mm}$ across are widely visible. A spaced cleavage developed during D1 is overprinted by an S4 crenulation cleavage, which is only visible in the more-micaceous lithologies.

9.2.2 Locality 2, Biotite Zone: North Esk Gorge (NO 583 736)

This locality is only c. $200 \mathrm{~m}$ upstream of locality 1. The lithologies are similar to those at locality 1, but also include beds of gritty psammite up to $1 \mathrm{~m}$ thick. The rocks look very similar to the chlorite-zone rocks, but a few flakes of brown biotite are visible in some layers. In thin section, the rocks are well-foliated semipelites and pelites with a good fabric formed by the alignment of muscovite and chlorite parallel to an S1 foliation. This fabric has been crenulated during D4. Post-dating the S1 fabric but pre-dating the s4 crenulations, are scattered, randomly orientated biotite porphyroblasts up to $1 \mathrm{~mm}$ long by 0.5 mm wide, which are visible on freshly broken surfaces of the morepelitic rocks.

9.2.3 Locality 3, Garnet Zone: Auchmull (NO 579 744)

One of the few accessible exposures of garnet-zone rocks is c. 800 $m$ upstream of locality 2, on the west bank of the River North Esk, near the end of the largely continuous exposures through the chlorite and biotite zones. Here, the rocks are grey-green schistose semipelites and pelites, similar to those at localities 1 and 2, but slightly coarser in grain size. The s1 foliation can be seen to be disrupted locally by a widely-spaced s2 cleavage, which gradually becomes more persistent northwards. The F4 folds are less numerous than at locations 1 and 2, and the 54 crenulation cleavage is only weakly developed. The locally abundant garnet porphyroblasts, up to $5 \mathrm{~mm}$ in diameter, are best seen on the southeast side of low exposures that protrude into the river. Elsewhere, where the rocks are more psammitic, garnet is hard to find. The garnets are seen in thin section to be poikilitic, with 
inclusions generally smaller than the grain size of the matrix. The folds in the inclusion trails show that the garnets grew post D2 and pre D4. Biotite porphyroblasts up to $3 \mathrm{~mm}$ across also occur.

9.2.4 Locality 4, Staurolite Zone: Craig of Weston (NO 583 756)

This is the upper of the two localities described by Harte (1987), in an area where there is much loose rock but little material definitely in situ. Staurolite is developed in the more-pelitic layers lying within a dominantly psammitic to semipelitic succession. Here, the dominant fabric in the pelitic rocks is a penetrative schistosity, which is related to the well-developed S2 spaced cleavage in the semipelites and psammites. Relics of S1 are preserved in the microlithons between the S2 cleavages. The S2 cleavage is in places folded by tight minor folds ascribed to D3, but the broad open F4 folds, characteristic of lower Glen Esk, are absent.

The pelites are considerably coarser grained than those at localities 1 to 3. A fabric defined by 2-3 mm-long muscovite and biotite crystals dominates the rock. Randomly orientated porphyroblasts of garnet and staurolite reach $5 \mathrm{~mm}$ in size. Some of the rocks contain anhedral porphyroblasts of poorly twinned plagioclase. Much of the coarsening of the fabric of the rocks and the prophyroblast growth probably occurred during D3.

\subsubsection{Locality 5, Kyanite Zone: Craigoshina (NO 574 766)}

At this locality, the rocks have the same coarse mica fabric as at locality 4, and the dominant fabric is $\mathrm{S} 2$, which is folded by minor F3 folds. In the Glen Esk-Glen Lethnot area in general, kyanite is best developed in silvery muscovite-rich pelites, many of which also contain abundant haematite porphyroblasts. These pelites form units up to $100 \mathrm{~m}$ thick, extending for up to $2 \mathrm{~km}$ along strike, and represent a distinctive lithology with a higher $\mathrm{Fe}^{3+} / \mathrm{Fe}^{2+}$ ratio than the surrounding rocks. Because of the oxidized nature of the rocks, kyanite is abundant at this locality despite the rocks being below the regional kyanite isograd for less-oxidized rocks (Chinner, 1960; Harte, 1966; Atherton and Brotherton, 1972). The fabric of the rocks is dominated by abundant well-aligned muscovite flakes with relatively little biotite. Porphyroblasts of garnet and staurolite reach $5 \mathrm{~mm}$ in size, and kyanite crystals are typically up to $3 \mathrm{~cm}$ in length. The kyanite porphyroblasts contain abundant inclusions of fine-grained haematite, and many of them have retrogressed to fine-grained aggregates of white mica. Better crystallized, and more typically blue kyanite is present in some of the numerous quartz veins. Garnet occurs in the haematite-kyanite schists but is fine grained and hence difficult to see (Chinner, 1960).

9.2.6 Locality 6, Sillimanite Zone: Hillock (NO 560 785)

At this locality schistose semipelites and pelites form rough craggy knolls. The rough surface of the more-pelitic rocks displays welts and knots up to several centimetres long, consisting of tiny fibres of sillimanite, usually intimately associated with quartz. Larger upstanding 'blobs' of fibrous sillimanite, $1-2 \mathrm{~cm}$ across, on weathered surfaces, can be found surrounding garnets. 
In this area, the main foliation of the rocks is still the composite S0-S1-S2, but in the cores of the tightest of the abundant flat-lying $F 3$ folds, the axial planar 53 cleavage merges with the earlier composite foliation. Minor folds showing crenulation of the mica fabric are attributed to D4. Between the kyanite-zone exposure and this exposure, the more-feldspathic semipelites and impure psammites show incipient segregations of quartzofeldspathic laminae, typically with biotitic selvedges, indicating the commencement of migmatization in susceptible lithologies.

\subsection{Interpretation}

The sequence of six typical exposures illustrates the effects of progressive regional metamorphism of pelitic rocks at medium to high pressures. The first five of these exposures occur within the Glen Lethnot Grit Formation, a 1500 m-thick succession of gritty, turbiditic psammites, with interbeds of semipelite and pelite, typically forming graded units 0.5-2.5 m thick (Harte, 1979; Gould, 2001). The sillimanite-zone exposure lies within the older, Glen Effock Schist Formation, which contains more semipelite and less psammite than the Glen Lethnot Formation.

The Barrovian index minerals are typically confined to the pelitic lithologies, although chlorite and biotite also occur in semipelites and impure psammites. Kyanite is best developed in an atypical, highly oxidized type of pelite characterized by silvery mica felts and numerous small haematite porphyroblasts. One of these pelites has been chosen for inclusion in the GCR site.

The local peak of metamorphism occurred progressively later in the higher metamorphic grades (Harte and Johnson, 1969; Robertson, 1994); it was syn to post D2 in the chlorite and biotite zones, post D2 but pre D3 in the garnet zone, and syn D3 in the staurolite, kyanite and sillimanite zones. The migmatization in the highestgrade rocks overlapped D3 in nearby Glen Clova (Robertson, 1991). Retrogressive effects, with alteration of biotite to chlorite and of staurolite and kyanite to sericitic felts, are associated with areas of intense D4 crenulation, and with the post-D4 folds associated with emplacement of the Mount Battock Pluton. Dempster (1985a) has used $\mathrm{Rb}-\mathrm{Sr}$ and $\mathrm{K}-\mathrm{Ar}$ dating to plot pressure-temperature paths and to work out the cooling and uplift history of the area. He concluded that the main metamorphism occurred at 520-490 Ma, with peak temperatures occurring progressively later at greater burial depths. After local uplift at 520-490 Ma, two major periods of uplift occurred at 460-440 Ma, associated with D4, and 410-390 Ma, associated with intrusion of the Mount Battock Pluton. Dempster (1985b) also estimated that peak metamorphism in the kyanite and sillimanite zones in nearby Glen Lethnot occurred at a temperature of $630-660{ }^{\circ} \mathrm{C}$ and a pressure of 5.7-6.2 kbar.

The temperature and pressure gradients estimated from the compositions of pairs of co-existing minerals is steeper than would be calculated from the exposed outcrop width of the zones in Glen Esk. This probably implies a considerable degree of tectonic thinning within the Glen Lethnot Grit Formation. A clue to the timing of the thinning occurs in areas a short distance to the 
east, where Phillips and Auton (1997) described blastomylonites within Glen Lethnot Formation rocks south of the Mount Battock Pluton. From their mineral textures, they deduced that most of the mylonitization and accompanying attentuation of the metamorphic zones occurred during D2.

\subsection{Conclusions}

The Glen Esk GCR site is within the internationally recognized type area for the Barrovian type of regional metamorphism. It was here in 1893 that George Barrow first erected a scheme of metamorphic zones based upon the first appearance of various index minerals with increasing metamorphic grade in pelitic rocks. These zones are typical of regional metamorphism at moderate to high pressures within the greenschist and amphibolite facies and have subsequently been recognized throughout the world. The GCR site provides, within a short distance, examples of Dalradian pelitic rocks from all of the Barrovian metamorphic zones, which are characterized, with increasing grade, by chlorite, biotite, garnet, staurolite, kyanite and sillimanite.

The exposures are all readily accessible and are invaluable for teaching purposes. Only the garnet-zone exposure is of less than excellent quality, and even it is acceptable. The index minerals can mostly be seen with the naked eye, and all are conspicuous under a hand lens. The exposures can also be used to demonstrate the development of folds and cleavages during successive deformation and progressive coarsening of texture within rocks of increasing metamorphic grade.

Thin sections from these rocks have enabled the timing of growth of the various minerals to be worked out with respect to the four regional deformations that affected Dalradian rocks of the eastern Grampian Highlands. Further work could involve electron-microprobe analysis of co-existing mineral phases to work out the temperature and pressure during deformation in different parts of the site. However, such studies would be partly hampered by the effects of retrogression that are particularly associated with the D4 deformation.

\section{GARRON POINT TO MUCHALLS (NO $894 \quad 877-$ NO 907 921)}

\section{C.W. Thomas}

\subsection{Introduction}

The east coast of the Grampian Highlands, north of Stonehaven, provides a continuously exposed and largely accessible section through Southern Highland Group metasedimentary rocks (Figure 32). The outcrops reveal in outstanding detail, the characteristics of the original sedimentary rocks and their response to metamorphism and deformation. In particular, there is a continuous section across the Tay Nappe, from the Flat Belt, across the Highland Border Downbend, into the Highland Border steep Belt and the 
downward-facing complex hinge-zone of the nappe, which is truncated here by the Highland Boundary Fault (Figure 33). In addition, distinctive metamorphic mineral assemblages are developed within the pelitic rocks, which differ from those of the 'Buchan' metamorphism to the north, and the 'Barrovian' metamorphism to the west.

The importance of this coast section has long been recognized. Although the study of the metamorphic mineral assemblages has been an important feature (e.g. Williamson, 1953; Harte and Hudson, 1979), it is the study of the structure that has been particularly important and highly relevant to the regional Dalradian structure. Anderson (1942, 1947a) was the first to describe and interpret the geological structure of the coast, relating this to the structure he observed in the River North Esk. And Stringer (1957) identified the four main phases of deformation, which he traced from the coast along the Highland Border to the south-west. However, it was Shackleton (1958) who recognized the monoformal Highland Border Downbend, and was able to show, by combining way-up evidence in the metasedimentary rocks with the geometrical relationships between first cleavage and bedding, that the first fold structures in the Highland Border Steep Belt are downward-facing. In other words, he showed that the sequence was already inverted prior to folding around the Highland Border Downbend. This inversion was attributed to the emplacement of an early nappe, equivalent to the Tay Nappe of Perthshire. However, the recognition of a right-way-up succession in the Tarfside district to the west led Harte (1979) to propose that the coast section may not lie on the inverted limb of the Tay Nappe, but on the right-way-up limb of an underlying 'Tarfside Nappe'. This interpretation was supported by Booth (1984), who also concluded that the coast section lies on a rightway-up fold limb. But more-recent work by the British Geological Survey during the remapping of 1:50 000 Sheet 67 (Stonehaven, 1999) indicated that this interpretation is difficult to substantiate. Younging evidence in outcrops to the north of the Highland Border Downbend shows that the rocks are generally inverted, which is more consistent with the traditional interpretation that the coast section lies in the lower, inverted limb of the Tay Nappe.

\subsection{Description}

The GCR site extends for some $5 \mathrm{~km}$ from the southern end of Skatie Shore at Garron Point (NO 894 877), to Ritchie Shore (NO 907 921), some $300 \mathrm{~m}$ south-east of Muchalls. The coast is dominated by steep cliffs, locally up to $30 \mathrm{~m}$ or more in height, above a rock platform that is exposed at mid to low tides.

The metasedimentary rocks are very well bedded. Bedding is generally planar, although beds do wedge out locally. Graded bedding is abundant and is seen particularly well in the south of the site, where the metamorphic grade is lower. The succession is dominated by metasandstone (psammite), with metasiltstone (semipelite) and metamudstone (pelite) common in many places. The metasandstones vary from fine-grained, thinly bedded units to massive, very coarse-grained and sometimes pebbly or microconglomeratic units in excess of $2 \mathrm{~m}$ in thickness. To the 
north of the Highland Border Downbend, calcsilicate-bearing layers commonly occur in the centre of metasandstone beds. These are thought likely to be of diagenetic origin, but now contain garnet, amphibole and plagioclase. Units containing volcanic debris, informally known as 'green beds' and a notable feature of the Southern Highland Group elsewhere, are conspicuously absent from the coast section, exacerbating correlation problems.

The structure of the coast section is complex. Four major phases of deformation are developed between Garron Point and Findon Ness (NO 944 974), to the north of the GCR site, and three of these are readily observed within the site. The site is divided into two structural domains by the Highland Border Downbend (Figures 32 and 33). This major structure cuts the coast at Castle Rock of Muchalls (NO 899 907), where it is very sharply defined, much more so than in many other areas of the Highland Border region. The coast to the north of the downbend is occupied generally by relatively shallow-dipping strata of the Flat Belt. To the south of the downbend, strata dip steeply, generally to the north-northwest, in the Highland Border steep Belt.

D1 structures dominate the southern part of the GCR site along Skatie Shore and Perthumie Bay, and this early phase of deformation appears to be generally more intense than in some other areas where lithostratigraphically equivalent rocks are exposed (e.g. in the Aberfoyle district; see the Duke's Pass GCR site report). It is manifested most obviously as coarsely spaced, anastomising cleavages (S1) in gritty metasandstone beds. Tight to isoclinal F1 folds can be shown to be present on the basis of changes in younging direction, but hinges are very rarely seen. The best example is exposed below mid tide on the rock platform in the southern part of Perthumie Bay. In this example, the Sl cleavage is seen to fan around the hinge. On the basis of the facing of the S1 cleavages observed in the southern part of the site, it is clear that the F1 fold system is not cylindrical, and F1 fold plunges are markedly variable.

D2 structures probably occur throughout the GCR site, but are only readily observable north of Perthumie Bay. In addition, it appears that the D2 deformation is not pervasive. D2 is manifested by complex minor structures that deform the first cleavage in the metasandstones in a very characteristic manner, giving rise to what is most easily described as a very coarse crenulation cleavage. The minor F2 folds formed within this cleavage have axial planes that are approximately parallel to the bedding and have markedly curvilinear hinges. F2 folds to the south of the Highland Border Downbend plunge generally to the south-west. To the north of the downbend they plunge to the north. Larger F2 folds of bedding are developed more commonly in the northern part of the coast section, where they are tight to isoclinal in form. The D2 deformation is probably heavily partitioned into the pelitic rocks, but the finegrained and recrystallized nature of these lithologies obscures the D1-D2 relationships that are so readily observed in the coarsegrained metasandstones. D2 deformation is generally considered to just pre-date or be synchronous with the peak of metamorphism.

The D3 deformation is not well developed within the GCR site; unequivocal D3 structures are best observed in the Portlethen area 
about $6 \mathrm{~km}$ to the north of Muchalls. Folds just north of Red Man (NO 892 888), ascribed by Booth to D3 (Booth, 1984; see also Harte et al., 1987, locality 6), are thought more likely to have resulted from D1 deformation. Locally developed cleavages of obscure origin might be due to D3 effects, but their relationships to other cleavages are commonly ambiguous and they could well have arisen from local strain partitioning.

The D4 deformation is complex and probably occurred over a protracted period, involving early extension, followed by compression. The observable effects of this phase of deformation are focussed on the Highland Border Downbend. F4 folds are overturned towards the downbend from both the south and the north. They are open to close, parallel fold structures that become more intense towards the downbend. In the steep Belt, F4 folds are centimetre- to ten metre-scale structures. In the Flat Belt, F4 folds range in scale from small, centimetre-sized structures to large folds on the scale of tens of metres. These larger structures produce local steep zones that form the short limbs of the folds. Crenulation cleavages are best developed in pelitic beds and in laminae within the hinge regions of the folds. F4 folds plunge at shallow angles mainly to the south-west and, less frequently, to the north-east. F4 axial planes dip at shallow angles to the north-west.

Faults and dislocations are a common feature of the coast section. In general, they appear to become more common towards the Highland Border Downbend from the south and are common in the Flat Belt towards Muchalls, where they result in a complex, incised coastline. In broad terms, they can be divided into low-angle and high-angle sets.

The low-angle faults were probably related to D4 compression after the formation of the Highland Border Downbend, probably originating as thrust structures during or after the development of F4 folds. Good examples of low-angle faults are observed in Hall Bay (NO 898 899). One at the northern end of Hall Bay is clearly a thrust, having a thin gouge along the fault plane. Low-angle discontinuities are displaced by a steep fault in the section east of Craigview (NO 9050 9127), about $1 \mathrm{~km}$ south of Muchalls. This suggests that the steep faults post-date the low-angle faults.

Two sets of steep faults are identified. A dominant set trending north-west is responsible for the deeply incised coastline north of the Highland Border Downbend, particularly around Doonie Point (NO 903 910) and on the promontory at Grim Haven, south of Muchalls. These faults generally dip steeply to the north-east or south-west and the available field evidence indicates that they are normal faults. The other conjugate set trends north-east and dips steeply to the south-east or north-west, but these faults are relatively uncommon compared to the NW-trending set. They are roughly parallel to the regional strike and the Highland Boundary Fault and might be related to the formation of the Highland Border Downbend.

The metamorphism within the coast section is characterized by a rapid increase in grade northwards from the Highland Boundary Fault. This is manifested by the development of distinctive mineral assemblages in the pelitic rocks, most notably chloritoid + biotite and andalusite, the latter in place of the kyanite that is 
characteristic of the classic Barrovian assemblages of the Angus glens to the south-west. The presence of chloritoid and andalusite led Harte (1975) to define the 'Stonehavian' metamorphic assemblage sequence, which is intermediate between the relatively highpressure Barrovian and high-temperature Buchan sequences (Harte and Hudson, 1979). Biotite + chlorite-bearing pelitic rocks at Skatie Shore become garnet-bearing in the northern part of Perthumie Bay. Chloritoid appears first in the northern part of Red Man in highly aluminous pelites (Harte and Hudson, 1979). The main appearance of chloritoid results from the discontinuous reaction between garnet and chlorite to yield chloritoid + biotite, this being the chloritoid isograd in the Stonehavian sequence. Staurolite first appears just to the north of Red Man (NO 892 888), initially resulting from reaction between chloritoid and chlorite to produce staurolite + biotite and then from the terminal breakdown of chloritoid to give staurolite + garnet + biotite. Andalusite is the stable aluminosilicate polymorph throughout the site. The staurolite + biotite assemblages coupled with the presence of andalusite indicate peak metamorphic pressures of no more than about 3 kbar at temperatures in excess of $500^{\circ} \mathrm{C}$ (Spear, 1993).

\subsection{Interpretation}

There are no precise constraints on the age of the metasedimentary rocks within this GCR site. All are assigned to the Glen Lethnot Grit Formation, in the upper part of the Southern Highland Group. This formation is now generally considered to be broadly equivalent in its lithological character and lithostratigraphical level to the Ben Ledi Grit Formation of the Aberfoyle-Callander area, a correlation first suggested by Anderson (1942). However, the lack of significant marker horizons at this site precludes precise correlation. Although metasiltstones and metamudstones are common locally, metasandstones dominate. Their general sedimentological characteristics indicate deposition within a submarine fan system on a continental margin, generally by turbidity currents; mass-flow mechanisms are thought to have been responsible for the deposition of massive, very thick single units of coarse, gritty rocks.

The metasedimentary rocks were strongly deformed during the Grampian Event of the Caledonian Orogeny and three of the four main phases of deformation generally recognizable in the Dalradian are developed within the GCR site. The pre-D2 way-up of the section is critical to the interpretation of the overall structural setting. Although Harte (1979) proposed, by analogy with the Tarfside succession inland, that the coast section might lie in the rightway-up limb of a nappe lying below the Tay Nappe, all the available younging evidence in the Flat Belt indicates that the rocks are generally inverted. This, coupled with the downward-facing nature of the F1 folds in the steep Belt, indicates that the rocks are more-readily interpreted as lying within the inverted limb of an early nappe structure most simply correlated with the Tay Nappe. 


\subsection{Conclusions}

The coast between Garron Point and Muchalls contains outstanding exposures of Southern Highland Group metasedimentary strata in an area of the Highland Border region that is otherwise poorly exposed. The site is of national and international importance for the continuous section that it exhibits across the downbent complex hinge-zone of the Tay Nappe, the most intensively studied and, arguably, the most important structure in the Grampian Highlands. The effects of three deformation events (D1, D2 and D4) can be readily discerned and the site contains some of the first localities in the world at which downward-facing geological structures (e.g. synformal anticlines) were deduced from their smaller scale component structures by Robert Shackleton in 1958. The recognition of the facing of the early structures led to a radical re-interpretation of the structure of the south-eastern part of the Dalradian as a whole.

Metamorphism accompanying the deformation resulted in the generation of mineral assemblages in the pelitic rocks that are a distinctive feature of the area around the GCR site and indicate rapidly increasing metamorphic grade northwards from the Highland Boundary Fault. Metamorphic conditions were intermediate between those of the high-temperature Buchan zones to the north and those of the high-pressure Barrovian Zones to the south-west.

The ready accessibility of the outcrops, the excellent exposure and the nature of the lithologies make this an excellent site within which to demonstrate and teach structural geology and the temporal links between deformation and metamorphism within a classic orogenic belt.

\section{ACKNOWLEDGEMENTS}

This regional paper is the combined work of 7 authors, many of whom, in addition to their own site descriptions, have made valuable comments on other aspects of the work.

The paper has been compiled by P.W.G. Tanner and has been edited by D. Stephenson. The GCR editor was P.H. Banham and the referee was M.R.W. Johnson, who also provided valuable editorial suggestions. The project was cofunded by the Joint Nature Conservation Committee (JNCC) and the British Geological Survey (BGS) and has been managed by N.V. Ellis for JNCC and D.J. Fettes and M. Smith for BGS.

The initial site selection and site documentation for the Dalradian block of the Geological Conservation Review was by S.J. Moorhouse. Since then, much new mapping and refined interpretation has taken place, and the site list has been revised, firstly by J.E. Treagus and subsequently through a panel consisting of $R$. Anderton, A.L. Harris, J.R. Mendum, J.L. Roberts, P.W.G. Tanner, R. Threadgould and J.E. Treagus. The necessary amendments to the GCR documentation were greatly facilitated by R. Wignall (for Scottish Natural Heritage).

K.M. Goodenough and S.W. Horsburgh assisted with preliminary drafts of key maps and all diagrams were drafted for publication by 
S.C. White (JS Publications, Newmarket) and K.J. Henderson (BGS, Edinburgh). Photographs were scanned and prepared by B.M. McIntyre (BGS, Edinburgh). Photographs from the BGS collection are reproduced by kind permission of the Director, BGS () Natural Environment Research Council; all rights reserved (PR/23-27).

The first complete draft of the Dalradian GCR was submitted to the JNCC in June 2009. In 2010, the JNCC terminated its involvement in Earth Science conservation and abandoned its contractual agreements to publish the remaining GCR volumes. So, the authors are greatly indebted to Diarmad Campbell, Chief Geologist Scotland for the BGS, for funding the drafting of remaining figures and to the Geologists' Association and Elsevier, for ensuring that this volume is published as a special Issue of their Proceedings. We are particularly grateful to Neil Ellis of the JNCC for his efforts to secure a new publisher and to Professor James Rose, Editor in Chief of the PGA, for making it all happen.

Finally, on behalf of all of the site authors, we would like to record our thanks to the owners and managers of land and quarries who have allowed access to the sites, either during previous work or specifically for the GCR exercise.

\section{REFERENCES}

Agrell, S. O. (1942) 1. A petrological investigation of the adinoles at Dinas Head, Cornwall. 2. A petrofabric study of the Ben Vuroch granite and the adjacent schists in Perthshire. Unpublished PhD thesis, University of Cambridge.

Ahmed-Said Y. and Tanner P. W. G. (2000) P-T conditions during emplacement, and D2 regional metamorphism, of the Ben Vuirich Granite, Perthshire, Scotland. Mineralogical Magazine, 64, 737-53.

Ague, J.J. \& Baxter, E.F., 2007. Brief thermal pulses during mountain building recorded by $\mathrm{Sr}$ diffusion in apatite and multicomponent diffusion in garnet. Earth and Planetary Science Letters, 261, 500-516.

Allen, J. R. L. 1963. The classification of cross stratified units with notes on their origin. Sedimentology, 2, pp. 93-114.

Allison, A. (1933) The Dalradian succession in Islay and Jura. Quarterly Journal of the Geological Society, London, 89, 125-44.

Allison, A. 1941. Loch Awe succession and tectonics-KilmartinTayvallich-Danna. Quarterly Journal of the Geological Society, London, 96, 423-49.

Allison, I., May, F and Strachan, R.A. (1988) An Excursion guide to the Moine Geology of the Scottish Highlands. Scottish Academic Press for Edinburgh Geological Society and Geological Society of Glasgow.

Alsop, G.I. and Hutton, D.H.W. (1990) A review and revision of Dalradian stratigraphy in central and southern Donegal, Ireland. Irish Journal of Earth Sciences, 10, 181-98.

Alsop, G.I., Prave, A.R., Condon, D.J. and Phillips, C.A. (2000) Cleaved clasts in Dalradian conglomerates: possible evidence for Neoproterozoic compressional tectonism in Scotland and Ireland? Geological Journal, 35, 87-98.

Amos, B.J. (1960). The geology of the Bowmore district, Islay. Unpublished PhD thesis, University of London, Imperial College. 
Anderson, E M. (1923). The geology of the schists of the Schiehallion district. Quarterly Journal of the Geological Society of London, 79, 423-45.

Anderson, E M. (1951) The Dynamics of Faulting. (Second edition). (Edinburgh: Oliver and Boyd.)

Anderson, J. G. C., (1942) The stratigraphical order of the Dalradian schists near the Highland Border in Angus and Kincardineshire. Transactions of the Geological Society of Glasgow, 20, 223-37.

Anderson, J.G.C. (1947a) The geology of the Highland Border, Stonehaven to Arran. Transactions of the Royal Society of Edinburgh, 61, 479-515.

Anderson, J.G.C. (1947b) The Kinlochlaggan Syncline, southern Inverness-shire. Transactions of the Geological Society of Glasgow, 21, 97-115.

Anderson, J.G.C. (1948) Stratigraphic nomenclature of Scottish metamorphic rocks. Geological Magazine, 85, 89-96.

Anderson, J.G.C (1956). The Moinian and Dalradian rocks between Glen Roy and the Monadhliath Mountains, Inverness-shire. Transactions of the Royal Society of Edinburgh, 63, 15-36.

Anderton, R. (1974) Middle Dalradian sedimentation in Argyll, with particular reference to the Jura quartzite, Scarba conglomerate and Craignish phyllites. Unpublished PhD thesis, University of Reading.

Anderton, R. (1975) Tidal flat and shallow marine sediments from the Craignish Phyllites, Middle Dalradian, Argyll, Scotland. Geological Magazine, 112, 337-40.

Anderton, R. (1976) Tidal-shelf sedimentation: an example from the Scottish Dalradian. Sedimentology, 23, 429-58.

Anderton, R. (1977) The Dalradian rocks of Jura. Scottish Journal of Geology, 13, 135-42.

Anderton, R. (1979) Slopes, submarine fans and syn-depositional sedimentology of parts of the Middle and Upper Dalradian in the S.W. Highlands of Scotland. In The British Caledonides - Reviewed (eds. Harris, A. L., Holland, C. H. and Leake, B. E.), Geological Society, London, Special Publications, 8.

Anderton, R. (1980). Distinctive pebbles as indicators of Dalradian provenance. Scottish Journal of Geology, 16, 143-52.

Anderton, R. (1982) Dalradian deposition and the late Precambrian Cambrian history of the $N$ Atlantic region: a review of the early evolution of the Iapetus Ocean. Journal of the Geological Society of London, 139, 421-31.

Anderton, R. (1985) Sedimentation and tectonics in the Scottish Dalradian. Scottish Journal of Geology, 21, 407-36.

Anderton, R. (1988) Dalradian slides and basin development: a radical interpretation of stratigraphy and structure in the SW and Central Highlands of Scotland. Journal of the Geological society of London, 145, 669-78.

Arndt, N.T. and Nisbet, E.G. (editors) (1982) Komatiites. George Allen and Unwin, London.

Ashcroft W.A., Kneller B.C., Leslie, A.G. and Munro M. (1984) Major shear zones and autochthonous Dalradian in the northeast Scottish Caledonides. Nature, London 310, 760-2.

Ashworth, J.R. (1972) Migmatites of the Huntly-Portsoy area, northeast Scotland. Unpublished PhD thesis, University of Cambridge. 
Ashworth, J.R. (1975) The sillimanite zones of the Huntly-Portsoy area in the north-east Dalradian, Scotland. Geological Magazine, $112,113-224$.

Ashworth, J.R. (1976) Petrogenesis of migmatites in the HuntlyPortsoy area, north-east Scotland. Mineralogical Magazine, 40, $661-82$.

Ashworth, J.R. (1979) Comparative petrography of deformed and undeformed migmatites from the Grampian Highlands of Scotland. Geological Magazine, 116, 445-56.

Astin, T.R. and Rogers, D.A. (1991) 'Subaqueous shrinkage cracks' in the Devonian of Scotland re-interpreted. Journal of Sedimentary Petrology, 61, 850-9.

Atherton, M.P. (1977) The metamorphism of the Dalradian rocks of Scotland. Scottish Journal of Geology, 13, 331-70.

Atherton, M.P., and Brotherton, M.S. (1972) The composition of some kyanite-bearing regionally-metamorphosed rocks from the Dalradian. Scottish Journal of Geology, 8, 203-13.

Atherton, M.P. and Ghani, A.A. (2002) Slab breakoff: a model for Caledonian, Late Granite syn-collisional magmatism in the orthotectonic (metamorphic) zone of Scotland and Donegal. Lithos, 62, $65-85$.

Bailey, E.B. (1910) Recumbent folds in the schists of the Scottish Highlands. Quarterly Journal of the Geological Society of London, $66,586-620$.

Bailey, E. B. 1913. The Loch Awe Syncline (Argyllshire). Quarterly Journal of the Geological Society of London, 69, 280-307.

Bailey, E.B. (1917) The Islay anticline (Inner Hebrides). Quarterly Journal of the Geological Society of London, 72, 132-64.

Bailey, E.B. (1922) The structure of the South west Highlands of Scotland. Quarterly Journal of the Geological Society of London, 78, 82-131.

Bailey, E.B. (1925) Perthshire tectonics: Loch Tummel, Blair Atholl and Glen Shee. Transactions of the Royal Society of Edinburgh, 53, 671-98.

Bailey, E.B. (1930) New Light on Sedimentation and Tectonics. Geological Magazine, 67, 77.

Bailey, E.B. (1934) West Highland tectonics: Loch Leven to Glen Roy. Quarterly Journal of the Geological Society of London, 90, $462-523$.

Bailey, E.B. (1938) Eddies in mountain structure. Quarterly Journal of the Geological Society of London, 94, 607-25.

Bailey, E B. (1953). Facies changes versus sliding: Loch Leven, Argyll. Geological Magazine, 90, 111-13.

Bailey, E.B. (1960) The geology of Ben Nevis and Glencoe and the surrounding country. (2nd edition). Memoir of the Geological Survey of Great Britain, Sheet 53 (Scotland).

Bailey, E.B., and McCallien, W. (1937). Perthshire tectonics: Schiehallion to Glen Lyon. Transactions of the Royal society of Edinburgh, 59, 79-118.

Bailey, E B, and MacGregor, M. 1912. The Glen Orchy Anticline, Argyllshire. Quarterly Journal of the Geological Society of London, Vol. 68, 164-179.

Bailey, E.B., and Maufe, H.B. (1916) The geology of Ben Nevis and Glen coe and the surrounding country. (1st edition). Memoir of the Geological Survey of Great Britain, Sheet 53 (Scotland). 
Bain, J.A., Briggs, D.A. and May, F. (1971) Geology and mineralogical appraisal of an extensive talc-magnesite deposit in the Shetlands. Transactions of the Institute of Mining and Metallurgy, 80, B77-B84.

Baker, A.J. (1985) Pressures and temperatures of metamorphism in the eastern Dalradian. Journal of the Geological Society of London, 142, 137-48.

Baker, A.J. (1987) Models for the tectonothermal evolution of the eastern Dalradian of Scotland. Journal of Metamorphic Geology, 5, 101-18.

Baker, A.J., and Droop, G.T.R. (1983) Grampian metamorphic conditions deduced from mafic granulites and sillimanite-Kfeldspar gneisses in the Dalradian of Glen Muick, Scotland. Journal of the Geological Society of London, 140, 489-97.

Baldwin, C.T. and Johnson, H.D. (1977) The Dalradian rocks of Lunga, Luing and Shuna. Scottish Journal of Geology, 13, 143-54.

Banks, C. J. (2005). Neoproterozoic Basin Analysis: a combined sedimentological and provenance study in the Grampian Group, Central Highlands, Scotland. Unpublished PhD Thesis, University of Keele.

Banks, C.J. (2007) Exceptional preservation of sedimentary structures in metamorphic rocks: an example from the upper Grampian Group, Creag Stalcair, Perthshire. Scottish Journal of Geology, 43, 9-14.

Banks, C.J. and J.A. Winchester (2004). Sedimentology and stratigraphic affinities of Neoproterozoic coarse clastic successions, Glenshirra Group, Inverness-shire Scotland. Scottish Journal of Geology 40, 159-174.

Banks, C.J., Smith, M., Winchester, J.A., Horstwood, M.S.A., Noble, S.R. and Ottley, C.J. (2007) Provenance of intra-Rodinian basinfills: the lower Dalradian Supergroup, Scotland. Precambrian Research, 153, 46-64.

Barreiro, B.A. (1998) U-Pb systematics on zircon from the Keith and Portsoy granites, Grampian Highlands, Scotland. NERC Isotope Geosciences Laboratory Report Series No. 132.

Barrow, G. (1893) On an intrusion of muscovite-biotite gneiss in the south-east Highlands of Scotland, and its accompanying metamorphism. Quarterly Journal of the Geological Society of London, 49, 330-58.

Barrow, G. (1904) Moine gneisses of the east central Highlands and their position in the Highland sequence. Quarterly Journal of the Geological Society of London, 60, 400-44.

Barrow, G. (1912) On the geology of Lower Deeside and the southern Highland border. Proceedings of the Geologists' Association, 23, 274-90.

Barrow G. and Cunningham Craig E.H. (1912) The geology of the districts of Braemar, Ballater and Glen Clova. Memoir of the Geological Survey of Great Britain, Sheet 65 (Scotland).

Barrow, G, Grant Wilson, J S, and Cunningham Craig, E H. (1905). The geology of the country around Blair Atholl, Pitlochry and Aberfeldy. Memoir of the Geological Survey of Great Britain, Sheet 55 (Scotland).

Basahel, A.N. (1971) The Dalradian stratigraphy and structure of southern Islay, Argyll. Unpublished PhD thesis. University of Liverpool.

Batchelor, R.A. (2011) Geochemistry of Torridonian tuffs and contemporary phosphorites; potential for correlation of 
Torridonian sequences in NW Scotland. Scottish Journal of Geology, 47, 133-142.

Baxter, E.F., Ague, J.J. and Depaolo, D.J. (2002) Prograde temperature-time evolution in the Barrovian type-locality constrained by $\mathrm{Sm} / \mathrm{Nd}$ garnet ages from Glen Clova, Scotland. Journal of the Geological Society, London, 159, 71-82.

Beddoe-Stephens B. (1990) Pressures and temperatures of Dalradian metamorphism and the andalusite-kyanite transformation in the northeast Grampians. Scottish Journal of Geology 26, 3-14.

Bell, A. M. (1981) Vergence: an evaluation. Journal of Structural Geology, Volume 3, 197-202.

Bendall, C.A. (1995). A geochronological, structural and metamorphic study of rocks from the central and SW Dalradian of Scotland. Unpublished PhD thesis, University of Manchester

Bentley, M.R. (1986) The tectonics of Colonsay, Scotland. Unpublished PhD thesis, University of Wales, Aberystwyth.

Bentley, M.R. (1988). The Colonsay Group. In Winchester, J.A (ed.) Later Proterozoic stratigraphy of the Northern Altlantic Regions. Blackie and Son Ltd., London, 119-30.

Bentley, M.R., Maltman, A.J., and Fitches, W.R. (1988) Colonsay and Islay: a suspect terrane within the Scottish Caledonides. Geology, 16, 26-8.

Bingen B., Demaiffe D. and van Breemen O. (1998) The $616 \mathrm{Ma}$ old Egersund basaltic dyke swarm, SW Norway, and late Neoproterozoic opening of the Iapetus Ocean. Journal of Geology, 106, 565-74.

Bingen, B., Griffin, W.L. Torsvik, T.H. and Saeed, A. (2005) Timing of late Neoproterozoic glaciation on Baltica constrained by detrital zircon geochronology in the Hedmark Group, south-east Norway. Terra Nova, 17, 250-58.

Bliss, G.M. (1977) The micropalaeontology of the Dalradian. Unpublished PhD thesis, University of London, Imperial College.

Bluck, B.J. (1983) Role of the Midland Valley of Scotland in the Caledonian Orogeny. Transactions of the Royal Society of Edinburgh: Earth Sciences, 74, 119 -136.

Bluck, B.J. (1984) Pre-Carboniferous history of the Midland Valley of Scotland. Transactions of the Royal Society of Edinburgh: Earth Sciences, 75, 275-95.

Bluck, B.J. (2000) 'Where ignorance is bliss 'tis a folly to be wise' (Thomas Gray 1716-1761) - controversy in the basement blocks of Scotland. Scottish Journal of Geology, 36, 97-101.

Bluck, B.J. (2001) Caledonian and related events in Scotland. Transactions of the Royal Society of Edinburgh: Earth Sciences, 91, 375-404.

Bluck, B.J. (2002) The Midland Valley Terrane. In: Trewin, N.H. (ed.) The Geology of Scotland. The Geological Society, London, $149-66$.

Bluck, B.J. (2010) The Highland Boundary Fault and the Highland Boundary Complex. Scottish Journal of Geology, 46, 113-124.

Bluck B.J. and Dempster T.J. (1991) Exotic metamorphic terranes in the Caledonides: tectonic history of the Dalradian block, Scotland. Geology, 19, 1133-6.

Bluck B.J., Dempster T.J., and Rogers G. (1997) Allochthonous metamorphic blocks on the Hebridean passive margin, Scotland. Journal of the Geological Society of London 154, 921-4.

Bluck, B.J., Gibbons, W. and Ingham, J.K. (1992). Terranes. 1-4 in Atlas of palaeogeography and lithofacies. Cope, J.C.W., Ingham, 
J.K., and Rawson, P.F. (editors). Geological Society of London Memoir, No. 13.

Bluck B.J., Halliday A. N., Aftalion M., and Macintyre R.M. (1980) Age and origin of the Ballantrae ophiolite and its significance to the Caledonian orogeny and Ordovician time scale. Geology 8, 49295 .

Bluck, B.J. and Ingham, J.K. (1997) The Highland Border controversy: a discussion of "New evidence that the Lower Cambrian Leny Limestone at Callander, Perthshire belongs to the Dalradian Supergroup, and a reassessment of the 'exotic' status of the Highland Border Complex". Geological Magazine, 134, 563-70.

Bluck B.J., Ingham J.K., Curry G.B., and Williams A. (1984) The significance of a reliable age from some Highland Border rocks in Central Scotland. Journal of the Geological Society of London 139, 451-4.

Boersma, J.R. (1969) Internal structures of some tidal megaripples on a shoal in the Westerschelde estuary, the Netherlands. Geologie on Mijnbouw, 48, 409-14.

Booth, J.E. (1984) Structural, stratigraphic and metamorphic studies in the SE Dalradian Highlands. Unpublished PhD thesis. University of Edinburgh.

Borradaile, G.J. (1970) The west limb of the Loch Awe syncline and the associated cleavage fan. Geological Magazine, 107, 459-467.

Borradaile, G.J. (1972a) The structural and stratigraphic history of the Dalradian rocks of the Northern Loch Awe syncline, Argyllshire. Unpublished PhD thesis, University of Liverpool.

Borradaile, G.J. (1972b) Variably oriented co-planar primary folds. Geological Magazine, 190, 89-98.

Borradaile, G. J. (1973) Dalradian structure and stratigraphy of the northern Loch Awe district, Argyllshire. Transactions of the Royal Society of Edinburgh, 69, 1-21.

Borradaile, G.J. (1974). Bulk finite strain estimates from the deformation of Neptunian dykes. Tectonophysics, 22, 127-39.

Borradaile, G.J. (1977) The Dalradian rocks of the northern Loch Awe district. Scottish Journal of Geology, 13, 155-64.

Borradaile, G.J. (1979). Pre-tectonic reconstruction of the Islay anticline: implications for the depositional history of Dalradian rocks in the SW Highlands. In The Caledonides of the British Isles-reviewed. Harris, A L, Holland, C H, and Leake, B E (editors). Special Publication of the Geological Society of London, No. 8, pp. 229-38.

Borradaile, G.J. and Johnson, H.D. (1973) Finite strain estimates from the Dalradian Dolomitic Formation, Islay, Argyll, Scotland. Tectonophysics, 18, 249-59.

Boué, A. (1820) Essai Géologique sur l'Écosse. Ve Courcier, Paris.

Bouma, A. H. (1962). Sedimentology of some Flysch Deposits, a Graphic Approach to Facies Interpretation. Elsevier Co. Amsterdam, $168 \mathrm{pp}$.

Bowden, A.J. (2007) Book review: MacCulloch's 1840 Geological Map of Scotland. Scottish Journal of Geology, 43, 181-4.

Bowes, D.R. and Convery, H.J.E. (1966) The composition of some Ben Ledi grits and its bearing on the origin of albite schists in the south-west Highlands. Scottish Journal of Geology, 2, 67-75.

Bowes, D.R. and Wright, A.E. (1967) The explosion breccia pipes near Kentallen, Scotland and their geological setting. Transactions of the Royal Society of Edinburgh, 67, 109-43. 
Bowes, D.R. and Wright, A.E. (1973) Early phases of Caledonian deformation in the Dalradian of the Ballachulish district, Argyll. Geological Journal, 8, 333-44.

Bowring, S., Myrow, P., Landing, E., Ramezani, J. and Grotzinger, J. (2003) Geochronological constraints on Terminal Neoproterozoic events and the rise of metazoans. Geophysical Research Abstracts 5, p13219.

Bradbury, H.J. (1978) Stratigraphic, structural, igneous and metamorphic history of the Dalradian rocks of the Ben Vrackie-Ben Vuirich district, Tayside, Scotland. Unpublished PhD thesis, University of Liverpool.

Bradbury, H.J. (1979) Migmatization, deformation and porphyroblast growth in the Dalradian of Tayside, Scotland. In The Caledonides of the British Isles - Reviewed Harris, A.L., Holland, C.H. and Leake, B.E. (eds). Geological Society, London, Special Publications, 8, 351-6.

Bradbury, H.J. (1985) The Caledonian metamorphic core: an Alpine model. Journal of the Geological Society of London, 142, 129-36.

Bradbury, H.J., and Harris, A.L. (1982) Low grade Dalradian sediments carrying spaced cleavage; Polyphase deformation of spaced cleavage. In Atlas of deformational and metamorphic rock fabrics. Borradaile, G J, Bayly, M B, and Powell, C McA (editors). Springer Verlag, Berlin, pp. 100-9.

Bradbury, H.J., Harris, A.L. and Smith, R.A. (1979). Geometry and emplacement of nappes in the Central Scottish Highlands. In The Caledonides of the British Isles - reviewed. (eds. Harris, A.L., Holland, C.H. and Leake, B.E.), Special Publication of the Geological Society of London, 8, 213-20.

Bradbury H.J., Smith R.A. and Harris A.L. (1976) 'Older' granites as time-markers in Dalradian evolution. Journal of the Geological Society, London, 132, 677-84.

Brasier, M.D., Ingham, J.K. and Rushton, A.W.A. (1992) Cambrian. 13-18 in Atlas of Palaeogeography and Lithofacies. Cope, J.C.W., Ingham, J.K. and Rawson, P. F. (editors). Memoirs of the Geological Society, London, 13.

Brasier, M.D. and Mcilroy, D. (1998) Neonereites uniserialis from c. $600 \mathrm{Ma}$ year old rocks in western scotland and the emergence of animals. Journal of the Geological Society, London, 155, 5-12.

Brasier, M.D. and Shields, G. (2000) Neoproterozoic chemostratigraphy and correlation of the Port Askaig glaciation, Dalradian Supergroup of Scotland. Journal of the Geological Society, London, 157, 909-14.

Brasier, M.D., McCarron, G., Tucker, R., Leather, J., Allen, P. and Shields, G. (2000) New U-Pb zircon dates for the Neoproterozoic Ghubrah glacaiation and for the top of the Huqf Supergroup, Oman. Geology, 28, 175-8.

Briden, J.C., Turnell, H.B. and Watts, D.R. (1984) British palaeomagnetism, Iapetus Ocean and the Great Glen Fault. Geology $12,136-9$.

Burgess J.G, Graham, C.M. and Harte, B. (1981). Kyanite and chloritoid phyllites from the chlorite zone of the Scottish Highlands. Journal of the Geological Society of London, 138, p. 634 (abstract).

Burt, C.E. (2002) Sedimentary environments and basin evolution of the upper Dalradian: Tayvallich Subgroup and Southern Highland Group. Unpublished PhD thesis, Kingston University. 
Burton, C.J., Hocken, C., MacCallum, D. and Young, M.E. 1983. Chitinozoa and the age of the Margie Limestone of the North Esk. Proceedings of the Geological Society of Glasgow Vol. 124-125, 2732 .

Cannat M. (1989) Late Caledonian northeastward ophiolite thrusting in the Shetland Islands, U.K. Tectonophysics 169, 257-70.

Canning J.C., Henney P.J., Morrison M.A. and Gaskarth J.W. (1996) Geochemistry of late Caledonian minettes from northern Britain: implications for the Caledonian sub-continental lithospheric mantle. Mineralogical Magazine 60, 221-36.

Canning, J.C., Henney, P.J., Morrison, M.A., Van Calsteren, P.W.C., Gaskarth, J.W. and Swarbrick, A. (1998) The Great Glen Fault: a major vertical lithospheric boundary. Journal of the Geological Society, London, 155, 425-8.

Carty, J.P. (2001) Deformation, metamorphism, magmatism and fluidflow in the Portsoy Shear Zone, N.E. Scotland. Unpublished PhD thesis, University of Derby.

Cawood, P.A., McCausland, P.J.A. and Dunning, G.R. (2001) Opening Iapetus: constraints from the Laurentian margin in Newfoundland. Geological Society of America Bulletin, 113, 443-53.

Cawood, P.A., Nemchin, A.A., Smith, M. and Loewy, S. (2003). Source of the Dalradian Supergroup constrained by U-Pb dating of detrital zircon and implications for the East Laurentian margin. Journal of the Geological Society of London 160, 231-46.

Cawood, P.A., Nemchin, A.A., Strachan, R.A., Prave, A.R. and Krabbendam, M. (2007) Sedimentary basin and detrital zircon record along East Laurentia and Baltica during assembly and breakup of Rodinia. Journal of the Geological Society, London, 164, 257-75.

Chew, D.M. (2001) Basement protrusion origin of serpentinite in the Dalradian. Irish Journal of Earth Science, 19, 23-35.

Chew, D.M., Daly, J.S., Magna, T., Page, L.M., Kirkland, C.L., Whitehouse, M.J. and Lam, R. (2010) Timing of ophiolite obduction in the Grampian orogen. Geological Society of America Bulletin, 122, 1787-1799.

Chew, D.M., Fallon, N., Kennelly, C., Crowley, Q. and Pointon, (2009) Basic volcanism contemporaneous with the Sturtian glacial episode in NE Scotland. Earth and Environmental Science Transactions of the Royal Society of Edinburgh, 100, 399-415

Chew, D.M., Graham, J.R. and Whitehouse, M.J. (2007) U-Pb zircon geochronology of plagiogranites from the Lough Nafooey (= Midland Valley) arc in western Ireland: constraints on the onset of the Grampian orogeny. Journal of the Geological Society, London Vol. $164,747-50$.

Chinner, G.A. (1957) The metamorphic history of the Glen Clova district, Angus. Unpublished PhD Thesis, University of Cambridge.

Chinner, G.A. (1960) Pelitic gneisses with varying ferrous/ferric ratios from Glen Clova, Angus, Scotland. Journal of Petrology, 1, $178-217$.

Chinner, G.A. (1961) The origin of sillimanite in Glen Clova, Angus. Journal of Petrology Vol. 2, 312-23.

Chinner, G.A. (1966) The distribution of pressure and temperature during Dalradian metamorphism. Quarterly Journal of the Geological Society of London, 122, 159-86.

Chinner, G.A. (1978) Metamorphic zones and fault displacement in the Scottish Highlands. Geological Magazine, Vol. 115, 37-45. 
Chinner, G.A. and Heseltine, F.J. (1979) The Grampian andalusite/kyanite isograd. Scottish Journal of Geology, Vol. 15, $117-127$.

Coats, J.S., Pease, S.F. and Gallagher, M.J. (1984) Exploration of the Scottish Dalradian. 21-34 in Prospecting in areas of glaciated terrain. (London: Institution of Mining and Metallurgy.)

Coats, J.S., Smith, C.G., Gallagher, M.J., May, F., Fortey, N.J. and Parker, M.E. (1978) Stratabound barium-zinc mineralisation in Dalradian schist near Aberfeldy, Scotland: preliminary report. Institute of Geological Sciences, Mineral Reconnaisance Programme Report No. 26.

Coats, J.S., Smith, C.G., Fortey, N.J., Gallagher, M.J., May, F. and McCourt, W.J. (1980) stratabound barium-zinc mineralization in Dalradian schist near Aberfeldy. Transactions of the Institution of Mining and Metallurgy (Section B: Applied Earth Science), 89, 110-22.

Coats, J.S., Smith, C.G., Gallagher, M.J., May, F., McCourt, W.J., Parker, M.E. and Fortey, N.J. (1981) Stratabound barium-zinc mineralisation in Dalradian schist near Aberfeldy, Scotland: final report. Institute of Geological Sciences, Mineral Reconnaissance Programme Report No. 40.

Collerson, K.D., Jesseau, C.W. and Bridgewater, D. (1976). Contrasting types of bladed olivine in ultramafic rocks from the Archaean of Labrador. Canadian Journal of Earth Sciences, 13, 44250 .

Collinson, J. (1994). Sedimentary deformational structures. pp. 95125 In Maltman, A. (ed.). The geological deformation of sediments. Chapman and Hall.

Collinson, J.D. and Thompson, D.B. 1988. Sedimentary Structures. George Allen and Unwin, London. 207 pp.

Condon, D.J. and Prave, A.R. (2000). Two from Donegal: Neoproterozoic glacial episodes on the northeast margin of Laurentia. Geology, 28, 951-4.

Cooper, M.R. and Johnston, T.P. (2004) Central Highlands (Grampian) Terrane. 9-24, in: Mitchell, W.I. (editor), The Geology of Northern Ireland-Our Natural Foundation (2nd edition). Geological Survey of Northern Ireland, Belfast.

Coward, M.P. (1983) The thrust and shear zones of the Moine Thrust Zone of NW Scotland. Journal of the Geological Society of London $140,795-811$.

Coward, M.P. (1990) The Precambrian, Caledonian and Variscan framework to NW Europe. In Tectonic Events Responsible for Britain's Oil and Gas Reserves. Hardman, R.F.P. and Brooks, J. (eds) Geological Society, London, Special Publications, 55, 1-34.

Craig G. Y., McIntyre D. B., and Waterston C. D. (1978) James Hutton's Theory of the Earth: the lost drawings. Scottish Academic Press, Edinburgh.

Crane A., Goodman S., Krabbendam M., Leslie A. G., Paterson I. B., Robertson S. And Rollin K. E. (2002) Geology of the Glen Shee District. Memoir of the British Geological Survey. Sheet 56W with parts of sheets 55E, 65W and 64E (Scotland).

Cummins, W.A. and Shackleton, R.M. (1955) The Ben Lui recumbent syncline. Geological Magazine, 92, 353-62.

Cunningham Craig, E.H. (1904) Metamorphism in the Loch-Lomond District. Quarterly Journal of the Geological Society, London, 60, 10-31. 
Cunningham Craig, E.H. (2000) (written 1901). Explanation of Sheet 38 (Loch Lomond). Selected documents from the BGS Archives No 3. British Geological Survey Technical Report No. wo/00/05.

Cunningham Craig, E.H., Wright, W.B. and Bailey, E.B. (1911) The Geology of Colonsay and Oronsay with parts of Ross of Mull. Memoir of the Geological Survey of Scotland, Sheet 35 (Scotland).

Curry, G.B., Bluck, B.J., Burton, C.J., Ingham, J.K., Siveter, D.J. And Williams, A. (1984) Age, evolution and tectonic history of the Highland Border Complex, Scotland. Transactions of the Royal Society of Edinburgh: Earth Sciences, 75, 113-33.

Cutts, K.A., Hand, M., Kelsey, D.E. and Strachan, R.A. (2011) P-T constraints and timing of Barrovian metamorphism in the Shetland Islands, Scottish Caledonides: implications for the structural setting of the Unst ophiolite. Journal of the Geological Society, $168,1265-1284$.

Dallmeyer, R.D., Strachan, R.A., Rogers, G., Watt, G.R. and Friend, C.R.L. (2001) Dating deformation and cooling in the Caledonian thrust nappes of north Sutherland, Scotland: insights from 40Ar/39Ar and Rb-Sr chronology. Journal of the Geological Society of London 158, 501-12.

Daly, J.S., Muir, R.J. and Cliff, R.A. (1991) A precise U-Pb zircon age for the Inishtrahull syenitic gneiss, County Donegal, Ireland. Journal of the Geological Society, London, 148, 639-42.

Dalziel, I.W.D. (1994) Precambrian Scotland as a Laurentia-Gondwana link: Origin and significance of cratonic promontories. Geology, $22,589-92$.

Dalziel, I.W.D. (1997) Neoproterozoic-Paleozoic geography and tectonics; review, hypothesis, environmental speculation. Geological Society of America Bulletin 109(1), 16-42.

Davidek, K., Landing, E., Bowring, S.A., Westrop, S.R., Rushton, S.A., Fortey, R.A. And Adrain, J. (1998) New Uppermost Cambrian U$\mathrm{Pb}$ date from Avalonian Wales and age of the Cambrian-Ordovician boundary. Geological Magazine, 135, 303-09.

Deer, W.A., Howie, R.A. and Zussman, J. (1992). An Introduction to the Rock Forming Minerals, 2nd ed. Longman Scientific and Technical, London.

Dempster, T.J. (1983) Studies of orogenic evolution in the Scottish Dalradian. Unpublished PhD thesis, University of Edinburgh.

Dempster, T.J. (1985a) Uplift patterns and orogenic evolution in the Scottish Dalradian. Journal of the Geological society of London, 142, 111-128.

Dempster, T.J. (1985b) Garnet zoning and metamorphism of the Barrovian type. Contributions to Mineralogy and Petrology, 89, 308.

Dempster T.J. and Bluck B.J. (1991) The age and tectonic significance of the Bute amphibolite, Highland Border Complex, Scotland. Geological Magazine 128, 77-80.

Dempster, T.J. and Harte, B. (1986) Polymetamorphism in the Dalradian of the Central Scottish Highlands. Geological Magazine, Vol. 123, 95-104.

Dempster, T.J., Hudson, N.F. and Rogers, G. (1995). Metamorphism and cooling of the NE Dalradian. Journal of the Geological Society, London, 152, 383-90.

Dempster, T.J., Rogers, G., Tanner, P.W.G., Bluck, B.J., Muir, R.J., Redwood, S.D., Ireland, T.R. and Paterson, B.A. (2002) Timing of deposition, orogenesis and glaciation within the 
Dalradian rocks of Scotland: constraints from U-Pb zircon ages. Journal of the Geological Society, London, 159, 83-94.

Dewey, H. and Flett, J.S. (1911) On some British pillow lavas and the rocks associated with them. Geological Magazine, 8, 202-9, $240-8$.

Dewey J. F. (1969) Evolution of the Appalchian/Caledonian orogen. Nature, London 222, 124-9.

Dewey, J.F. (2005) Orogeny can be very short. Proceedings of the National Academy of Sciences, USA Vol. 102, 15286-93.

Dewey, J.F. and Mange, M. (1999) Petrography of Ordovician and Silurian sediments in the western Irish Caledonides: tracers of a short-lived Ordovician continent-arc collision orogeny and the evolution of the Laurentian Appalachian-Caledonian margin. In: Continental Tectonics (edited by MacNiocaill, C. and Ryan, P. D.) . Geological Society, London, Special Publication, 164, 55-107.

Dewey, J.F. and Pankhurst, R.J. (1970) The evolution of the Scottish Caledonides in relation to their radiometric age pattern. Transactions of the Royal Society of Edinburgh, 68, 361-89.

Dewey, J.F. and Ryan, P.D. (1990) The Ordovician evolution of the South Mayo Trough, Western Ireland. Tectonics, 9, 887-903.

Dewey J.F. and Shackleton R.M. (1984) A model for the evolution of the Grampian tract in the early Caledonides and Appalachians. Nature, London 312, 115-21.

Dewey, J.F. and Strachan, R.A. (2003) Changing Silurian-Devonian relative plate motion in the Caledonides; sinistral transpression to sinistral transtension. Journal of the Geological Society, London, 160, 219-229.

Dickin, A.P. (1992). Evidence for an Early Proterozoic crustal province in the North Atlantic region. Journal of the Geological Society, London, 149, 483-6.

Dickin, A.P., and Bowes, D.R. (1991) Isotopic evidence for the extent of the early Proterozoic basement of Scotland and northwest Ireland. Geological Magazine, 128, 385-8.

Droop, G.T.R. (1987). A general equation for estimating $\mathrm{Fe}^{3+}$ concentrations in ferromagnesian silicates or oxides from microprobe analysis using stoichiometric criteria. Mineralogical Magazine, 51, 431-55.

Droop G.T.R. and Charnley N. (1985) Comparative geobarometry of pelitic hornfelses associated with the Newer Gabbros: a preliminary study. Journal of the Geological Society of London $142,53-62$.

Droop, G.T.R., Clemens, J.D. and Dalrymple, D.J. (2003) Processes and conditions during contact anatexis, melt escape and restite formation: the Huntley Gabbro complex, NE Scotland. Journal of Petrology Vol. 44, 995-1029.

Donovan, R.N. and Foster, R.J. (1972). Subaqueous shrinkage cracks from the Caithness Flagstone Series (Middle Devonian) of northeast Scotland. Journal of Sedimentary Petrology, 42, 309-17.

Downie, C. (1975) The Precambrian of the British Isles: Palaeontology. In A Correlation of Precambrian Rocks in the British Isles (eds. Harris, A.L., Shackleton, R.M., Watson, J.V., Downie, C., Harland, W.B. and Moorbath, S.). Special Report of the Geological Society of London, No. 6. Pp. 113-15

Downie, C. (1984) Acritarchs in British stratigraphy. Special Report of the Geological Society of London, No. 17.

Downie, C., Lister, T.R., Harris, A.L. and Fettes, D.J. (1971) A palynological investigation of the Dalradian rocks of 
Scotland. Report of the Institute of Geological Sciences, No. $71 / 9$.

Dymoke, P.L. (1989) Geochronological and petrological studies of the thermal evolution of the Dalradian, South-west Scottish Highlands. Unpublished PhD thesis, University of Edinburgh.

Eby G. N. (1992) Chemical subdivision of the A-type granitoids: petrogenetic and tectonic implications. Geology, 20, 641-4.

Edwards, M.B. (1986) Glacial Environments. 416-436 in: Sedimentary Environments and facies (Editor: H.G. Reading). Blackwell Scientific

Publications.

Elles, G.L. (1926) The geological structure of Ben Lawers and Meall Corranaich (Perthshire). Quarterly Journal of the Geological Society of London, 82, 304-31.

Elles, G.L. (1931) Notes on the Portsoy coastal district. Geological Magazine, 68, 24-34.

Elles, G.L. (1935) The Loch na Cille Boulder Bed and its place in the Highland succession. Quarterly Journal of the Geological Society of London, 91, 111-49.

Elles, G.L. and Tilley, C.E. (1930) Metamorphism in relation to structure in the Scottish Highlands. Transactions of the Royal Society of Edinburgh, 56, 621-46.

Ellis, D.J. and Green, D.H. (1979) An experimental study of the effect of $\mathrm{Ca}$ upon garnet-clinopyroxene $\mathrm{Fe}-\mathrm{Mg}$ exchange equilibria. Contributions to Mineralogy and Petrology, 71, 13-22.

Ellis, N.V., Bowen, D.Q., Campbell, S., Knill, J.L., McKirdy, A.P., Prosser, C.D., Vincent, M.A. and Wilson, R.C.L. (1996) An Introduction to the Geological Conservation Review. Joint Nature Conservation Committee, Peterborough.

Emery, M. (2005) Polyorogenic history of the Moine rocks of Glen Urquhart, Inverness-shire. Unpublished PhD thesis, University of Portsmouth.

Evans, J.A., Fitches, W.R. and Muir, R.J. (1998) Laurentian Clasts in a Neoproterozic Tillite in Scotland. Journal of Geology, 106, $361-9$.

Evans, J.A, and Soper, N.J. (1997) Discussion on metamorphism and cooling of the $\mathrm{NE}$ Dalradian and $\mathrm{U}-\mathrm{Pb}$ and $\mathrm{Rb}-\mathrm{Sr}$ geochronology of magmatism and metamorphism in the Dalradian of Connemara, western Ireland. Journal of the Geological Society, London, 154, 357-60.

Evans, R.H.S. and Tanner, P.W.G. (1996). A late Vendian age for the Kinlochlaggan Boulder Bed (Dalradian)? Journal of the Geological Society, London, 153, 823-6.

Evans, R.H.S. and Tanner, P.W.G. (1997). Discussion on a late Vendian age for the Kinlochlaggan Boulder Bed (Dalradian): reply. Journal of the Geological Society, London, 154, 917-19.

Eyles, C.H. (1988) Glacially - and tidally - influenced shallow marine sedimentation of the Late Precambrian Port Askaig Formation, Scotland. Palaeogeography, Palaeoclimatology, Palaeoecology, 68, 1-25.

Eyles, C.H. and Eyles, N. (1983) Glaciomarine model for upper Precambrian diamictiles of the Port Askaig Formation, Scotland. Geology, 11, 692-6.

Eyles, N. and Clark, M. (1985) Gravity-induced soft-sediment deformation in glaciomarine sequences of the upper Proterozoic Port Askaig Formation, Scotland. Sedimentology, 32, 789-814. 
Fairchild, I.J. (1977) Phengite spherules from the Dalradian Bonnahaven Formation, Islay, Scotland: Glauconitized microfossils. Geological Magazine, 114, 355-64.

Fairchild, I.F. (1980a) Sedimentation and origin of a Late Precambrian "dolomite" from Scotland. Journal of Sedimentary Petrology, 50, 423-46.

Fairchild, I.J. (1980b) Stages in a Precambrian dolomitization, Scotland: Cementing versus replacement textures. Sedimentology, 27, 631-50.

Fairchild, I.J. (1980c) The structure of NE Islay. Scottish Journal of Geology, 16, 189-97.

Fairchild, I.J. (1985) Comment on 'Glaciomarine model for Upper Precambrian diamictiles of the Port Askaig Formation, Scotland'. Geology, 13, 89-90.

Fairchild, I.J. (1985) Petrography and carbonate chemistry of some Dalradian dolomitic metasediments: preservation of diagenetic textures. Journal of the Geological Society, London, 142, 167-85.

Fairchild, I.J. (1989) Dolomitic stromatolite-bearing units with storm deposits from the Vendian of East Greenland and Scotland: a case of facies equivalence. In Caledonian and related Geology of Scandinavia (ed. Gayer, R. A.), pp. Graham and Trotman, London, pp. 275-283.

Fairchild, I.J. (1991) Itinerary II: Topmost Islay Limestone (Appin Group), Port Askaig and Bonahaven Formations (Argyll Group) Port Askaig area, Islay. In The Late Precambrian geology of the Scottish Highlands and Islands (ed. Lister, C.J.) Geologists' Association Guide No. 44, pp. 33-41.

Fairchild, I.J. (1993) Balmy shores and icy wastes: the paradox of carbonates associated with glacial deposits in Neoproterozoic times. Sedimentology Review, 1, 1-16.

Ferry, J.M. and Spear, F.S. (1978) Experimental calibration of the partitioning of $\mathrm{Fe}$ and $\mathrm{Mg}$ between biotite and garnet. Contributions to Mineralogy and Petrology, 66, 113-17.

Fettes, D.J., (1968). Metamorphic structures of Dalradian rocks in North East Scotland. Unpublished PhD thesis, University of Edinburgh.

Fettes, D.J. (1970) The structural and metamorphic state of the Dalradian rocks and their bearing on the age of emplacement of the basic sheet. Scottish Journal of Geology, Vol. 6, 108-118.

Fettes, D.J. (1971) Relation of cleavage and metamorphism in the Macduff Slates. Scottish Journal of Geology, 7, 248-53.

Fettes, D.J. (1979) A metamorphic map of the British and Irish Caledonides. In: Harris, A.L., Holland, C.H. and Leake, B.E. (eds) The Caledonides of the British Isles-Reviewed. Geological Society, London, Special Publications, 8, 307-21.

Fettes, D.J. and Desmons, J. (editors) (2007) Metamorphic Rocks: a Classification and Glossary of Terms. Recommendations of the International Union of Geological Sciences Subcommission on the Systematics of Metamorphic Rocks. Cambridge University Press, Cambridge

Fettes, D.J., Graham, C.M., Harte, B., and Plant, J.A. (1986a) Lineaments and basement domains; an alternative view of Dalradian evolution. Journal of the Geological Society of London, 143, 453-64.

Fettes, D.J., Graham, C.M., Sassi, F.P., and Scolari, A. (1976) The lateral spacing of potassic white micas and facies series 
variations across the Caledonides. Scottish Journal of Geology, $12,227-36$.

Fettes, D.J., Harris, A.L. and Hall, L.M. (1986b) The Caledonian geology of the Scottish Highlands. In Synthesis of the Caledonian rocks of Britain. Proceedings of the NATO Advanced Study Institute. Fettes, D J, and Harris, A L (editors). Reidel Dordrecht, pp. 303-34.

Fettes, D.J., Leslie A.G., Stephenson D., and Kimbell S.F. (1991) Disruption of Dalradian stratigraphy along the Portsoy Lineament from new geological and magnetic surveys. Scottish Journal of Geology 27, 57-73.

Fettes, D.J., Long, C.B., Bevins, R.E., Max, M.D., Oliver, G.J.H., Primmer, T.J., Thomas, L.J. and Yardley, B.W.D., 1985. Grade and time of metamorphism in the Caledonide Orogen of Britain and Ireland. . 5 In, Harris, A.L.(ed), The Nature and Timing of Orogenic Activity in the Caledonian Rocks of the British Isles. Memoir of the Geological Society, London, 9.

Fettes, D.J., Macdonald, R., Fitton, J.G., Stephenson, D. and Cooper, M.R. (2011) Geochemical evolution of Dalradian metavolcanic rocks: implications for the break-up of the Rodinia supercontinent. Journal of the Geological Society, 168, 1133-1146.

Fisk, S. (1986) An oxygen isotope study of siliceous rocks associated with stratabound mineralisation in scotland and Ireland. Unpublished PhD thesis, University of Strathclyde.

Fitches, W. R. And Maltman, A. J. (1984) Tectonic development and stratigraphy of the western margin of the Caledonides: Islay and Colonsay, Scotland. Transactions of the Royal society of Edinburgh, 75, 365-82.

Fitches, W.R., Muir, R.J., Maltman, A.J. and Bentley, M.R. (1990) Is the Colonsay-west Islay block of SW Scotland an allochthonous terrane? Evidence from Dalradian tillite clasts. Journal of the Geological Society, London, 147, 417-20.

Fitches, W.R., Pearce, J.A., Evans, J.A. and Muir, R.J. (1996) Provenance of the late Proterozoic Dalradian tillite clasts, Inner Hebrides, Scotland. In Precambrian Crustal Evolution in the North Atlantic Region (ed. Brewer, T. S.), pp. 367-77.

Flinn, D., (1953) Regional metamorphism and migmatisation in Delting, Shetland. Unpublished PhD thesis, University of London, Imperial College.

Flinn, D. (1954) On the time relations between regional metamorphism amd permeation in Delting, Shetland. Quarterly Journal of the Geological Society of London, 110, 177-99.

Flinn, D. (1961) Continuation of the Great Glen Fault beyond the Moray Firth. Nature, London, 191, 589-91.

Flinn, D. (1967) The metamorphic rocks of the southern part of the Mainland of Shetland. Geological Journal, 5, 251-90.

Flinn, D. (1985) The Caledonides of Shetland. In Gee, D. G. and Sturt, B. A. (editors) The Caledonide Orogen-Scandinavia and Related Areas. John Wiley and Sons, Chichester. 1161-72.

Flinn, D. (1995) Formation of gneisses of migmatite and diatexite appearance in Yell, shetland by solid-state grain growth recrystallisation. Geological Journal, 30, 415-22.

Flinn, D. (1999) The Shetland Ophiolite. 31-33, 36-58 In Stephenson et al. (editors) Caledonian Igneous Rocks of Great Britain. Geological Conservation Review Series, No. 17. Joint Nature Conservation Committee, Peterborough, UK. 
Flinn, D. (2001) The basic rocks of the Shetland Ophiolite Complex and their bearing on its genesis. Scottish Journal of Geology, 37, $79-96$.

Flinn, D. (2007) The Dalradian rocks of Shetland and their implications for the plate tectonics of the northern Iapetus. Scottish Journal of Geology, Vol. 43, 125-42.

Flinn, D. in press. Geology of Unst and Fetlar in shetland. Memoir of the British Geological Survey, Sheet 131 (Scotland).

Flinn, D. and Moffat, D. T. 1985. A peridotitic komatiite from the Dalradian of Shetland. Geological Journal, 20, 287-292.

Flinn, D. and Moffat, D.T. (1986) A reply to R. W. Nesbitt and L. A. Hartmann. Geological Journal, 21, 207-9.

Flinn, D. and Pringle, I.R. (1976). Age of migmatisation in the Dalradian of Shetland. Nature, London, 259, 299-300.

Flinn, D., Frank, P.L., Brook, M. and Pringle, I.R. (1979) Basement-cover relations in shetland. In The Caledonides of the British Isles-reviewed. Harris, A.L., Holland, C.H. and Leake, B.E. (eds), Geological Society of London special Publication No. 8, 109-15.

Flinn, D., May, F., Roberts, J.L. and Treagus, J.E. (1972). A revision of the stratigraphic succession of the East Mainland of Shetland. Scottish Journal of Geology, 8, 335-343.

Flinn, D., Miller, J.A. and Roddam, D. (1991) The age of the Norwick hornblendic schists of Unst and Fetlar and the obduction of the Shetland ophiolite. Scottish Journal of Geology 27, 11-19.

Flinn, D. and Oglethorpe, R.J.D. (2005). A history of the Shetland ophiolite Complex. Scottish Journal of Geology, 41, 141-8.

Fortey, N.J., Coats, J.S., Gallagher, M.J., Greenwood, P.G. and Smith, C.G. (1993) Dalradian stratabound baryte and base metals near Braemar, NE Scotland. Transactions of the Institution of Mining and Metallurgy (Section B: Applied Earth Science), Vol. $102, \mathrm{~B} 55-64$.

Fortey, N.J. and Smith, C.G. (1986). Stratabound mineralisation in Dalradian rocks near Tyndrum, Perthshire. Scottish Journal of Geology, 22, 377-93.

France, D.S. (1971) Structure and metamorphism of Moine and Dalradian rocks in the Grampians of Scotland near Beinn Dorain between Tyndrum and Moor of Rannoch. Unpublished PhD thesis, University of Liverpool.

Francis, E.H. (1982). Magma and sediment-1: Emplacement mechanisms of late Carboniferous tholeittic sils in Northern Britain. Journal of the Geological Society, London, 139, 1-20.

Friedrich, A.M, Hodges, K.V., Bowring, S.A. and Martin, M.W. (1999) Geochronological constraints on the magmatic, metamorphic and thermal evolution of the Connemara Caledonides, western Ireland. Journal of the Geological Society, London, 156, 1217-30.

Friend, C.R.L., Kinny, P.D., Rogers, G., Strachan, R.A. and Patterson, B.A. (1997) U-Pb zircon geochronological evidence for Neoproterozoic events in the Glenfinnan Group (Moine Supergroup): the formation of the Ardgour granite gneiss, north-west Scotland. Contributions to Mineralogy and Petrology 128, 101-13.

Friend, C.R.L., Strachan, R.A., Kinny, P.D. and Watt, G.R. (2003) Provenance of the Moine Supergroup of NW Scotland; evidence from geochronology of detrital and inherited zircons from (meta) sedimentary rocks, granites and migmatites. Journal of the Geological Society, London 160, 247-57. 
Gallagher, M.J., Smith, C.G., Coats, J.S., Greenwood, P.G., Chacksfield, B.C., Fortey, N.J. and Nancarrow, P.H.A. (1989) Stratabound barium and base-metal mineralisation in Middle Dalradian metasediments near Braemar, Scotland. British Geological Survey, Mineral Reconnaisance Programme Report, No. 104.

Ganguly, J. (1979) Garnet and clinopyroxene solid solutions, and geothermometry based on Fe-Mg distribution coefficient. Geochemica and Cosmochemica Acta 43, 1021-9.

Garson, M.S, and Plant, J. (1973) Alpine Type Ultramafic Rocks and Episodic Mountain Building in the Scottish Highlands. Nature Physical Science, 242, 34-8.

Geikie, A. (1865) The scenery of scotland viewed in connection with its physical geology (with a geological map by sir Roderick I. Murchison and Archibald Geikie). Macmillan, London and Cambridge.

Geikie, A. (1897) Annual report of the Geological Survey of the United Kingdom and of the Museum of Practical Geology for the year ending December 31, 1896. In Appendix E from the 44th Report of the Department of Science and Art. (London: Her Majesty's Stationery Office.)

Gibbons, W. And Harris, A.L. (1994) A Revised Correlation of Precambrian rocks in the British Isles. Special Reports, Geological Society, London, 22.

Gillen, C. (1987) Huntly, Elgin and Lossiemouth. 149-160 in Excursion Guide to the Geology of the Aberdeen area. (editors N.H.Trewin, B.C. Kneller, and C. Gillen,). (Edinburgh: Scottish Academic press for Geological Society of Aberdeen).

Gillespie, M.R. and Styles, M.T. (1999). BGS rock classification scheme, Volume 1: Classification of igneous rocks, 2nd edition. British Geological Survey Research Report, RR/99/6

Glover, B.W. (1989). The sedimentology and basin evolution of the Grampian Group. Unpublished PhD Thesis. University of Keele.

Glover, B.W. (1993). The sedimentology of the Neoproterozoic Grampian Group and the significance of the Fort William Slide between Spean Bridge and Rubha Cuilcheanna, Inverness-shire. Scottish Journal of Geology, 29, 29-43.

Glover, B.W. (1998). Sedimentology and lateral extent of the Glenshirra succession, Monadhliath Mountains, Scotland. British Geological Survey Technical Report, WA/98/23.

Glover B.W., Key, R.M., May, F., Clark, G.C., Phillips, E.R. and Chacksfield, B.C. (1995). A Neoproterozoic multi-phase rift sequence: the Grampian and Appin groups of the southwestern Monadhliath Mountains of Scotland. Journal of the Geological Society of London, 152, 391-406.

Glover B.W. and McKie, T. (1996). A sequence stratigraphical approach to the understanding of basin history in orogenic Neoproterozoic successions: an example from the central Highlands of Scotland. In: Sequence stratigraphy in British Geology (eds. Hesselbo, S.P. and Parkinson, D.N. ). Geological Society of London, Special Publication, 103, 257-69.

Glover, B.W. and Winchester, J.A. (1989) The Grampian Group: a major Late Proterozoic clastic sequence in the central Highlands of Scotland. Journal of the Geological Society, London, 146, 8597 .

Goodman, S (1991) The Pannanich Hill Complex and the origin of the Crinan Subgroup migmatites in the North-eastern and Central Highlands. Scottish Journal of Geology, 27, 147-56. 
Goodman, S. (1994) The Portsoy-Duchray Hill Lineament; a review of the evidence. Geological Magazine 131, 407-15.

Goodman, S., Crane, A., Krabbendam, M. and Leslie, A.G. (1997) Correlation of lithostratigraphic sequences in a structurally complex area: Gleann Fearnach to Glen Shee, Scotland. Transactions of the Royal Society of Edinburgh, 87, 503-13.

Goodman, S, and Lappin, M.A. (1996) The thermal aureole of the Lochnagar Complex: mineral reactions and implications from thermal modelling. Scottish Journal of Geology, 27, 159-72.

Goodman, S., Leslie, A.G., Ashcroft, W.A. and Crane, A. (1990) The geology of the central part of sheet 65E (Ballater); contribution to the memoir. British Geological Survey Technical Report No. WA/90/59.

Goodman, S. and Winchester, J.A. (1993) Geochemical variations within metavolcanic rocks of the Dalradian Farragon Beds and adjacent formations. Scottish Journal of Geology, 29, 131-41.

Gorokhov, M., Siedlecka, A., Roberts, D., Melnikov, N.N. and Turchenko, T.L. (2001) Rb-Sr dating of diagenetic illite in Neoproterozoic shales, Varanger Peninsula, northern Norway. Geological Magazine, 138, 541-62.

Gould, D. (1997) The geology of the country around Inverurie and Alford. Memoir of the British Geological Survey, sheets 76E and 76W (Scotland).

Gould, D. (2001) Geology of the Aboyne district. Memoir of the British Geological Survey, Sheet 66W (Scotland).

Gower, P.J. (1973) The Middle-Upper Dalradian Boundary with special reference to the Loch Tay Limestone. Unpublished PhD thesis, University of Liverpool.

Gower, P.J. (1977) The Dalradian rocks of the west coast of the Tayvallich peninsula. Scottish Journal of Geology, 13, 125-33.

Gradstein, F.M., Ogg, J.G., and Smith, A.G., Agterberg, F.P., Bleeker, W., Cooper, R.A., Davydov, V., Gibbard, P., Hinnov, L.A., House, M.R., Lourens, L., Luterbacher, H.P., McArthur, J., Melchin, M.J., Robb, L.J., Shergold, J., Villeneuve, M., Wardlaw, B.R., Ali, J., Brinkhuis, H., Hilgen, F.J., Hooker, J., Howarth, R.J., Knoll, A.H., Laskar, J., Monechi, S., Plumb, K.A., Powell, J., Raffi, I., Röhl, U., Sadler, P., Sanfilippo, A., Schmitz, B., Shackleton, N.J., Shields, G.A., Strauss, H., Van Dam, J., van Kolfschoten, T., Veizer, J., and Wilson, D. (2004) A Geologic Time Scale 2004. Cambridge University Press, 589 pp.

Graham, C.M. (1976) Petrochemistry and tectonic significance of Dalradian metabasaltic rocks of the SW Scottish Highlands. Journal of the Geological Society, London, 132, 61-84.

Graham, C.M. (1983). High-pressure greenschist to epidoteamphibolite facies metamorphism of the Dalradian rocks of the SW Scottish Highlands. Geological Society Newsletter, 12, No. 4, 19.

Graham, C.M. (1986) The role of the Cruachan Lineament during Dalradian evolution. Scottish Journal of Geology, 22, 257-70.

Graham, C.M. and Borradaile, G.J. (1984). The petrology and structure of Dalradian metabasic dykes of Jura: implications for Dalradian evolution. Scottish Journal of Geology, 20, 257-70. Same page range as previous ref?

Graham, C.M. and Bradbury, H.J. (1981) Cambrian and late Precambrian basaltic igneous activity in the Scottish Dalradian: a review. Geological Magazine, 118, 27-37.

Graham, C.M., Greig, K.M., Sheppard, S.M.F. and Turi, B. (1983) Genesis and mobility of the $\mathrm{H}_{2} \mathrm{O}-\mathrm{CO}_{2}$ fluid phase during regional 
greenschist and epidote amphibolite facies metamorphism: a petrological and stable isotope study in the Scottish Dalradian. Journal of the Geological Society, London, 140, 577-599.

Graham, C.M. and Harte, B. (1985) Conditions of Dalradian metamorphism. Journal of the Geological Society, London, 142, 1-3.

Grant Wilson, J.S. (1882) Explanation of Sheet 97. Northern Aberdeenshire, Eastern Banffshire. Memoir of the Geological Survey, Scotland.

Grant Wilson, J.S. (1886) Explanation of Sheet 87, North-east Aberdeenshire and detached portions of Banffshire. Memoir of the Geological Survey, Scotland.

Grant Wilson, J.S., and Hinxman, L.W. (1890) Geology of central Aberdeenshire. Memoir of the Geological Survey of Scotland, Sheet 76 (Scotland).

Green, J.F.N. (1924) The structure of the Bowmore-Portaskaig District of Islay. Quarterly Journal of the Geological Society, London, 80, $72-105$.

Green, J.F.N. (1931) The South-west Highland Sequence. Quarterly Journal of the Geological Society of London 87, 513-550.

Gregory, J.W. (1910) Work for Glasgow geologists-the problems of the South-western Highlands. Transactions of the Geological Society of Glasgow 14, 1-29.

Gregory, J.W. (1916) Pre-Cambrian of Scotland. Handbuch der Regionaler Geologie, III, Part I, 34-42.

Gregory, J.W. (1928) The geology of Loch Lomond. Transactions of the Geological Society of Glasgow 18, 301-23.

Gregory, J.W. (1929) The Pre-Cambrian or Pre-Palaeozoic of Scotland. 28-42 in Evans, J. W. and Stubblefield, C. J. (editors) Handbook of the geology of Great Britain. Murby.

Gregory, J.W. (1930) The sequence in Islay and Jura. Transactions of the Geological Society of Glasgow Vol. 18, 420-441.

Gregory, J.w. (1931) Dalradian Geology: The Dalradian Rocks of Scotland and their Equivalents in other Countries. Methuen, London.

Greig, K.M., (1987) Metamorphosed carbonates and fluid behaviour in the Dalradian of S.W. Argyll, Scotland. Unpublished PhD thesis, University of Edinburgh

Grieve, A. (1996) Ruskin and Millais at Glenfinlas. The Burlington Magazine, 138, 228-234.

Gunn, A.G., Styles, M.T., Stephenson, D., Shaw, M.H. and Rollin, K. (1990) Platinum-group elements in ultramafic rocks of the Upper Deveron Valley, near Huntly, Aberdeenshire. Mineral Reconnaissance Programme Report, British Geological Survey, No. 115.

Gunn, W., Clough, C.T. and Hill, J.B. (1897) The Geology of Cowal, including the part of Argyllshire between the Clyde and Loch Fyne. Memoirs of the Geological Survey of Scotland, Sheets 29, 37 and 38 .

Hackman, B.D. and Knill, J.L. (1962) Calcareous algae from the Dalradian of Islay. Palaeontology, 5, 268-71.

Hall, A.J. (1993) Stratiform mineralisation in the Dalradian of Scotland. In Mineralisation in the British Isles. Pattrick, R.A.D., and Polya, D.A. (editors). Chapman and Hall, London, pp. $38-101$.

Hall, J., Brewer, J.A., Matthews, D.H. and Warner, M. (1984) Crustal structure across the Caledonides from the WINCH seismic 
reflection profile: Influences on the evolution of the Midland Valley of Scotland. Transactions of the Royal Society of Edinburgh: Earth Sciences, 75, 97-109.

Halliday, A.N., Graham, C.M., Aftalion, M. and Dymoke, P. (1989) The depositional age of the Dalradian Supergroup: U-Pb and $\mathrm{Sm}-\mathrm{Nd}$ isotopic studies of the Tayvallich Volcanics, Scotland. Journal of the Geological Society, London, 146, 3-6.

Hambrey, M.J. (1983) Correlation of the Late Proterozoic tillites in the North Atlantic region and Europe. Geological Magazine, 120, 209-32.

Hambrey, M.J. and Harland, W.B. (editors). (1981) Earth's prePleistocene glacial record. Cambridge University Press, Cambridge.

Hambrey, M.J. and Harland, W.B. (1985) The Late Proterozoic glacial era. Palaeogeography, Palaeoclimatology and Palaeoecology, 51, $255-72$.

Hambrey, M.J. and Waddams, P. (1981) Glaciogenic boulder-bearing deposits in the Upper Dalradian Macduff Slates, northeastern Scotland. In Earth's pre-Pleistocene glacial record. Hambrey, M.J. and Harland, W.B. (editors). Cambridge University Press, Cambridge, pp. 571-5.

Harkness, R. (1861) On the rocks of the portions of the Highlands of Scotland south of the Caledonian Canal; and on their equivalents in the north of Ireland. Quarterly Journal of the Geological Society of London 17, 256-71.

Harris, A.L. (1960) Dalradian geology of an area between Pitlochry and Blair Atholl. Unpublished PhD thesis, University of Wales, Aberystwyth.

Harris, A.L. (1962) Dalradian geology of the Highland Border, near Callander. Bulletin of the Geological Survey of Great Britain, 19, $1-15$.

Harris, A.L. (1963). Structural investigations in the Dalradian rocks between Pitlochry and Blair Atholl. Transactions of the Edinburgh Geological Society, 19, 256-278.

Harris, A.L. (1969) The relationships of the Leny Limestone to the Dalradian. Scottish Journal of Geology, 5, 187-90.

Harris, A.L. (1972) The Dalradian rocks at Dunkeld, Perthshire. Bulletin of the Geological Survey of Great Britain, 38, 1-10.

Harris, A.L. (1995) Nature and timing of orogenesis in the Scottish Highlands and the role of the Great Glen Fault. In Current perspectives in the Appalachian-Caledonian Orogen, Hibbard, J., van Stall, C.R. and Cawood, P.A. (editors) Geological Association of Canada, Special Paper 41, 65-79.

Harris, A.L., Baldwin, C.T., Bradbury, H.J., Johnson, H.D. and Smith, R.A. (1978) Ensialic basin sedimentation: the Dalradian Supergroup. In Crustal evolution in northwestern Britain, Bowes, D R, and Leake, B E (editors)Special Issue of the Geological Journal No. 10 . Seel House Press, Liverpool, pp. 115-38

Harris, A.L., and Bradbury, H.J. (1977) Discussion of 'The evolution and transport of the Tay Nappe'. Scottish Journal of Geology, 13, 81-3.

Harris, A.L., Bradbury, H.J. and McGonigal, N.H. (1976) The evolution and transport of the Tay Nappe. Scottish Journal of Geology, 12, 103-13.

Harris, A.L. And Fettes, D.J. (1972) Stratigraphy and structure of Upper Dalradian rocks at the Highland Border. Scottish Journal of Geology, 8, 253-64. 
Harris, A.L., Fettes, D.J. And Soper, N.J. (1998a) Age of the Grampian event: a Discussion of "New evidence that the Lower Cambrian Leny Limestone at Callander, Perthshire, belongs to the Dalradian supergroup, and a re-assessment of the "exotic" status of the Highland Border Complex". Geological Magazine, 135, 575.

Harris, A.L., Haselock, P.J., Kennedy, M.J., Mendum, J.R., Long, J.A., Winchester, J.A. and Tanner, P.W.G. (1994). The Dalradian Supergroup in Scotland, Shetland, and Ireland, In A Revised Correlation of the Precambrian Rocks of the British Isles (eds. W. Gibbons and A.L. Harris), Geological Society, London, Special Report No. 22, 33-53.

Harris, A.L., Parson, L.M., Highton, A.J. and Smith, D.I. 1981. New/Old Moine relationships between Fort Augustus and Inverness (Abstract). Journal of Structural Geology, 3, 187-88.

Harris, A.L. and Pitcher, W.S. (1975) The Dalradian Supergroup. In A Correlation of Precambrian Rocks in the British Isles. (eds. Harris, A. L., Shackleton, R. M., Watson, J.V., Downie, C., Harland, W. B. and Moorbath, S.), Special Reports of the Geological Society, London, 6, pp. 52-75.

Harte, B. (1966) Stratigraphy, structure and metamorphism in the south-eastern Grampian Highlands of Scotland. Unpublished PhD thesis, University of Cambridge.

Harte, B., (1975) Determination of a pelite petrogenetic grid for the eastern Scottish Dalradian. Yearbook of the Carnegie Institute, Washington, 74, 438-446.

Harte, B. (1979) The Tarfside succession and the structure and stratigraphy of the eastern Scottish Dalradian rocks. In Special Publications, Geological Society, London, 8 (eds. Harris, A. L., Holland, C. H. and Leake, B. E.), pp. 221-28.

Harte, B. (1987) Glen Esk Dalradian, Barrovian metamorphic zones. In Excursion Guide to the Geology of the Aberdeen area. (editors N.H.Trewin, B.C. Kneller, and C. Gillen,). Scottish Academic press for Geological Society of Aberdeen, Edinburgh, p 193-210.

Harte, B. (1988) Lower Palaeozoic metamorphism in the MoineDalradian belt of the British Isles. In The CaledonianAppalachian Orogen. Harris, A L, and Fettes, D J (editors). Special Publication of the Geological Society of London, No. 38, pp. 123-34.

Harte, B., Booth, J.E., Dempster, T.J., Fettes, D.J., Mendum, J.R. and Watts, D. (1984) Aspects of the post-depositional evolution of Dalradian and Highland Border Complex rocks in the Southern Highlands of Scotland. Transactions of the Royal society of Edinburgh, 75, 151-63.

Harte, B., Booth, J.E. and Fettes, D.J., (1987) Stonehaven to Findon: Dalradian Structure and Metamorphism. In Excursion Guide to the Geology of the Aberdeen Area (eds Trewin, N. H., Kneller, B. C. and Gillen, C.). Scottish Academic Press for Geological Society of Aberdeen, Edinburgh, pp. 211-26

Harte, B. and Dempster, T.J. (1987) Regional metamorphic zones: tectonic controls. Philosophical Transactions of the Royal society of London Vol. 321, 105-27.

Harte, B, and Hudson, N.F.C. (1979) Pelite facies series and the temperatures and pressures of Dalradian metamorphism in $E$ Scotland. in The Caledonides of the British Isles-Reviewed. (eds. A.L. Harris, C.H. Holland, and B.E. Leake, ) Geological Society of London Special Publication, 8, pp 323-37. 
Harte, B, and Johnson, M.R.W. (1969) Metamorphic history of Dalradian rocks in Glens Clova, Esk and Lethnot, Angus, Scotland. Scottish Journal of Geology, 5, 54-80.

Haselock, P.J. (1982) The geology of the Corrieyairack Pass area, Inverness-shire. Unpublished PhD thesis, University of Keele.

Haselock, P.J. (1984) The systematic geochemical variation between two tectonically separate successions in the southern Monadhliaths, Inverness-shire. Scottish Journal of Geology. 20, $191-205$.

Haselock, P.J. and Gibbons, W. (1990). The Central Highland controversy: a traverse through the Precambrian metasediments of the Central Highlands of Scotland. Episodes 13, 113-15.

Haselock, P.J. and Leslie, A.G. (1992). Polyphase deformation in Grampian Group rocks of the Monadhliath defined by a group magnetic survey. Scottish Journal of Geology 28, 81-7.

Haselock, P.J., Winchester, J.A. and Whittles, K.H. (1982). The stratigraphy and structure of the southern Monadhliath Mountains between Loch Killin and upper Glen Roy. Scottish Journal of Geology, 18, 275-90.

Heddle, M.F. (1878) Chapters on the mineralogy of Scotland. Chapter fourth - augite, hornblende and serpentinous change. Transactions of the Royal Society of Edinburgh 28, 453-555.

Heddle M. F. (1901) The mineralogy of Scotland. D. Douglas, Edinburgh.

Henderson, S.M.K. (1938) The Dalradian Succession of the Southern Highlands. Report of the meeting of the British Association for the Advancement of Science, Cambridge, 1938, 424.

Henderson, W.G. and Robertson, A.H.F. (1982). The Highland Border rocks and their relation to marginal basin development in the Scottish Caledonides. Journal of the Geological Society of London, $139,433-50$.

Henderson, W.G., Tanner, P.W.G. and Strachan, R.A. (2009) The Highland Border Ophiolite of Scotland: observations from the Highland Workshop field excursion of April 2008. Scottish Journal of Geology, 45, 13-18.

Hibbert, S. (1822) A Description of the Shetland Islands: comprising an account of their geology, scenary, antiquities and superstitions. Constable and Co., Edinburgh.

Hickman, A.H. (1975) The stratigraphy of late Precambrian metasediments between Glen Roy and Lismore. Scottish Journal of Geology, 11, 117-42.

Hickman, A H. (1978) Recumbent folds between Glen Roy and Lismore. Scottish Journal of Geology, 14, 191-212.

Hickman, A.H. and Roberts, J.L. (1977). Discussion of the North Ballachulish Dalradian. Journal of the Geological Society of London, 133, Part 3, 277-79.

Hickman, A.H. and Wright, A.E. (1983) Geochemistry and chemostratigraphical correlation of slates, marbles and quartzites of the Appin Group, Argyll, Scotland. Transactions of the Royal Society of Edinburgh: Earth Sciences, 73, 251-78.

Highton, A.J. (1986). Caledonian and pre-Caledonian events in the Moine south of the Great Glen Fault, Unpublished PhD thesis, University of Liverpool.

Highton, A.J. (1992). The tectonostratigraphical significance of pre-750 Ma metagabbros within the northern Central Highlands, Inverness-shire. Scottish Journal of Geology 28, 71-6. 
Highton, A.J. (1999). Solid Geology of the Aviemore District. Memoir of the British Geological Survey, Sheet 74E (Scotland).

Highton, A.J., Hyslop, E.K. and Noble, S.R. (1999).U-Pb zircon geochronology of migmatization in the northern Central Highlands: evidence for pre-Caledonian (Neoproterozoic) tectonmetamorphism in the Grampian Block, Scotland. Journal of the Geological Society, London, 156, 1195-204.

Hill, J.B. (1899) On the progressive metamorphism of some Dalradian sediments in the region of Loch Awe. Quarterly Journal of the Geological Society, London, 40, 470-93.

Hill, J.B. (1905) The geology of mid-Argyll. Memoirs of the Geological Survey, Scotland. Explanation of Sheet 37.

Hill, J. and Buist, D. (1994) A Geological Field Guide to the Island of Bute, Scotland. (editor Greensmith, J. T.) Geologists' Association Guide, No. 51, 95 pp. Warwick Press.

Hinxman, L.W. (1896). Explanation of Sheet 75. West Aberdeenshire, Banffshire, parts of Elgin and Inverness. Memoir of the Geological Survey, Scotland.

Hinxman, L. W. and Anderson, E. M. (1915). The geology of MidStrathspey and Strathdearn, including the country between Kingussie and Grantown, Scotland. Memoir of the Geological Survey, Scotland, sheet 74 (Scotland).

Hinxman, L. W., Carruthers, R. G. and Macgregor, M. (1923). The geology of Corrour and the Moor of Rannoch. Memoir of the Geological Survey, Scotland, Sheet 54 (Scotland).

Hinxman, L.W. and Grant Wilson, J.S. (1902) The geology of Lower Strathspey. Memoir of the Geological Survey, Scotland, Sheet 85 (Scotland).

Hoffmann, P.F., Condon, D.J., Bowring, S.A. and Crowley, J.L. (2004) U-Pb zircon date from the Neoproterozoic Ghaub Formation, Namibia: Constraints on Marinoan glaciation. Geology, 32, 817-20.

Holdsworth, R.E., Woodcock, N. and Strachan, R. (2000) Geological Framework of Britain and Ireland. In Geological History of Britain and Ireland (edited by Woodcock, N. and Strachan, R.) Blackwell Science, Oxford.

Holland, C.H. and Sanders, I.S. (editors) 2009. The Geology of Ireland (2nd edition). Dunedin Academic Press, Edinburgh. $576 \mathrm{pp}$.

Howarth, R.J. and Leake, B.E. (2002) The Life of Frank Coles Phillips (1902-1982) and the Structural Geology of the Moine Petrofabric Controversy. Memoir of the Geological Society, London, 23, $95 \mathrm{pp}$.

Hudson, N.F.C. (1976) Mineral facies in pelitic rocks, with particular reference to the Buchan type metamorphism of northeastern Scotland. Unpublished PhD thesis, University of Edinburgh.

Hudson, N.F.C. (1980) Regional metamorphism of some Dalradian pelites in the Buchan area, NE Scotland. Contributions to Mineralogy and Petrology, 73, 39-51.

Hudson, N.F.C. (1985) Conditions of Dalradian metamorphism in the Buchan area. Journal of the Geological Society of London, 142, $63-76$.

Hutchison, A.R. and Oliver, G.J.H. (1998) Garnet provenance studies, juxtaposition of Laurentian marginal terranes and timing of the Grampian Orogeny in Scotland. Journal of the Geological Society, London, 155, 541-50.

Hutton D.H.W. (1987) Strike slip terranes and a model for the evolution of the British and Irish Caledonides. Geological Magazine 124, 405-425. 
Hutton, D.H.W. and Alsop, G.I. (2004) Evidence for a major Neoproterozoic orogenic unconformity within the Dalradian Supergroup of NW Ireland. Journal of the Geological Society, London, 161, 629-40.

Hutton, D.H.W. and Alsop, G.I. (2005) Discussion on evidence for a major Neoproterozoic orogenic unconformity within the Dalradian Supergroup of NW Ireland. Journal of the Geological Society, London, 162, 221-4.

Hutton J. (1788) Theory of the Earth; or an Investigation of the Laws observable in the Composition, Dissolution, and Restoration of the Land upon the Globe. Transactions of the Royal Society of Edinburgh 1, 209-304.

Hyslop, E. K. (1992). Strain-induced metamorphism and pegmatite development in the Moine rocks of Scotland. Unpublished PhD thesis, University of Hull.

Hyslop, E.K. and Piasecki, M.A.J. (1999). Mineralogy, geochemistry and the development of ductile shear zones in the Grampian slide Zone of the Scottish Central Highlands. Journal of the Geological Society, London, 156, 577-90.

Hyslop, E.K. and Pickett, E.A. (1999) Stratigraphy and magmatism in the uppermost Dalradian of the SW Scottish Highlands: A field excursion to Tayvallich, Loch Avich and Tarbert (Loch Fyne). BGS Technical Report WA/99/73.

Indares, A. and Dunning, G.R. (1997) Coronitic metagabbro and eclogite from the Grenville Province of western Quebec; interpretation of $\mathrm{U}-\mathrm{Pb}$ geochronology and metamorphism. Canadian Journal of Earth Sciences 34, 891-901.

Jacques J.M. and Reavy R.J. (1994) Caledonian plutonism and major lineaments in the SW Scottish Highlands. Journal of the Geological Society, London, 151, 955-69.

Jamieson, T.F. (1861) On the structure of the south-west Highlands of Scotland. Quarterly Journal of the Geological society of London, 17, 133-45.

Jehu, T.J. and Campbell, R. (1917) The Highland Border rocks of the Aberfoyle District. Transactions of the Royal Society of Edinburgh, 52, 175-212.

Johnson, M.R.W. (1962) Relations of movement and metamorphism in the Dalradians of Banffshire. Transactions of the Edinburgh Geological Society, 19, 29-64.

Johnson, M.R.W. (1963) Some time relations of movement and metamorphism in the Scottish Highlands. Geologie en Mijnbouw, 42, $121-42$.

Johnson, M.R.W. (1965) Dalradian. In The Geology of Scotland (1st edition). Craig, G. Y. (ed.) Oliver and Boyd, Edinburgh. 117-60.

Johnson, M.R.W. (1983) Dalradian. In Geology of Scotland (2nd edition), Craig, G. Y. (ed.), Scottish Academic Press, Edinburgh, pp. 77-104.

Johnson, M.R.W. (1991) Dalradian. In Geology of Scotland (3rd edition). Craig, G. Y. (ed.) The Geological Society, London, pp. 125-60.

Johnson, M.R.W. and Harris, A.L. (1967) Dalradian-?Arenig relations in part of the Highland Border, Scotland, and their significance in the chronology of the Caledonian orogeny. Scottish Journal of Geology, 3, 1-16. 
Johnson, M.R.W. and Stewart, F.H. (1960) On Dalradian structures in north-east Scotland. Transactions of the Edinburgh Geological Society, 18, 94-103.

Johnson T.E. (1999) Partial melting in Dalradian pelitic migmatites from the Fraserburgh-Inzie Head area of Buchan, northeast Scotland. Unpublished PhD thesis, University of Derby.

Johnson T.E., Hudson N.F.C. and Droop G.T.R. (2001a) Partial melting in the Inzie Head gneisses: the role of water and a petrogenetic grid in KFMASH applicable to anatectic pelitic migmatites. Journal of Metamorphic Geology, 19, 99-118.

Johnson T.E., Hudson N.F.C. and Droop, G.T.R (2001b) Melt segregation structures within the Inzie Head gneisses of the northeastern Dalradian. Scottish Journal of Geology, 37, 59-72.

Johnson T.E., Hudson N.F.C. and Droop G.T.R. (2003) Evidence for a genetic granite-migmatite link in the Dalradian of NE Scotland. Journal of the Geological Society, London, 160, 447- 57.

Johnstone, G.S. (1966) British regional geology: the Grampian Highlands (3rd edition). HMSO, Edinburgh for Geological Survey and Museum.

Johnstone, G.S. (1975) The Moine Succession. In A Correlation of Precambrian Rocks in the British Isles (eds. Harris, A. L., Shackleton, R. M., Watson, J.V., Downie, C., Harland, W. B. and Moorbath, S.) Geological Society, London, Special Report, 6, 3042 .

Johnstone, G.S. and Smith, D.I. (1965) Geological observations concerning the Breadalbane Hydroelectric Project, Perthshire. Bulletin of the Geological Survey of Great Britain, 22, 1-52.

Johnstone, G.S. and Wright, J.E. (1957) The Geology of the tunnels of the Loch Sloy hydroelectric scheme. Bulletin of the Geological Survey of Great Britain, 12, 1-17.

Jones, K.A. (1959) The tectonic and metamorphic history of the Ben More-Am Binnein area, Western Perthshire. Unpublished PhD thesis, University of Wales, Swansea.

Kearns, S. (1989) Metamorphism of calc-silicate and related rocks from the Dalradian of N.E. Scotland. Unpublished PhD thesis, Derbyshire College of Higher Education.

Kennedy, M.J. (1975) The Fleur de Lys Supergroup: stratigraphic comparison of Moine and Dalradian equivalents in Newfoundland with the British Caledonides. Journal of the Geological Society, London, 131, 305-10.

Kennedy W.Q. (1946) The Great Glen Fault. Quarterly Journal of the Geological Society of London, 102, 41-76.

Kennedy, W.Q. (1948) On the significance of thermal structure in the Scottish Highlands. Geological Magazine, 85, 229-34.

Kessler, L.G. and Gollop, I.G. (1988) Inner shelf/shorefaceintertidal transition, Upper Precambrian, Port Askaig Tillite, Isle of Islay, Argyll, Scotland. In Tide Influenced Sedimentology, Environments and Facies (eds. de Boer, P. L., van Gelder, A. and Nio, S. D.), Reidal, Dohdrecht, pp. 341-58.

Key, R.M., Clark, G.C., May, F., Phillips, E.R., Chacksfield, B.C. and Peacock, J.D. (1997). Geology of the Glen Roy district. Memoir of the British Geological Survey, sheet 63W (Scotland).

Kilburn, C., Pitcher, W.S. and Shackleton, R.M. (1965) The stratigraphy and origin of the Portaskaig Boulder Bed series (Dalradian). Geological Journal, 4, 343-60. 
Kinny, P.D., Friend, C.R.L., Strachan, R.A., Watt, G.R. and Burns, I.M. (1999) U-Pb geochronology of regional migmatites in East Sutherland, Scotland; evidence for crustal melting during the Caledonian Orogeny. Journal of the Geological Society, London, 156, 1143-52.

Kinny, P.D., Strachan, R.A., Friend, C.R.L., Kocks, H., Rogers, G. and Paterson, B.A. (2003a) U-Pb geochronology of deformed metagranites in central Sutherland, Scotland; evidence for widespread late silurian metamorphism and ductile deformation of the Moine Supergroup during the Caledonian orogeny. Journal of the Geological Society of London, 160, 259-69.

Kinny, P.D., Strachan, R.A., Kocks, H. and Friend, C.R.L. (2003b) $\mathrm{U}-\mathrm{Pb}$ geochronology of late Neoproterozoic augen granites in the Moine Supergroup, NW Scotland: dating of rift-related, felsic magmatism during supercontinent break-up? Journal of the Geological Society of London, 160, 925-34.

Klein, G.D.V. (1970) Tidal origin of a Precambrian quartzite - the Lower Fine-grained Quartzite (Middle Dalradian) of Islay, Scotland. Journal of Sedimentary Petrology, 40, 973-85.

Klein, G.D.V. (1971) Tidal origin of a Precambrian quartzite - the Lower Fine-grained Quartzite (Middle Dalradian) of Islay, Scotland: Reply. Journal of Sedimentary Petrology, 41, 886-9.

Kneller, B.C. (1985) Dalradian basin evolution and metamorphism. Journal of the Geological Society of London, 142, 4 (abstract).

Kneller, B.C. (1987) A geological history of NE Scotland. 1-50. In Excursion guide to the geology of the Aberdeen area. Trewin, H.N., Kneller, B.C. and Gillen, C. (editors). Scottish Academic Press for Geological Society of Aberdeen, Edinburgh.

Kneller, B.C. (1988) The geology of part of Buchan. Unpublished PhD thesis, University of Aberdeen.

Kneller, B.C. and Aftalion M. (1987) The isotopic and structural age of the Aberdeen Granite. Journal of the Geological Society of London 144, 717-21.

Kneller, B.C. and Leslie, A.G. (1984) Amphibolite facies metamorphism in shear zones in the Buchan area of NE Scotland. Journal of Metamorphic Geology 2, 83-94.

Knill, J.L. (1959) Palaeocurrents and sedimentary facies of the Dalradian metasediments of the Craignish-Kilmelfort district. Proceedings of the Geologists' Association, 70, 273-84.

Knill, J.L. (1960) The tectonc pattern in the Dalradian of the Craignish-Kilmelfort District, Argyllshire. Quarterly Journal of the Geological Society of London, 115, 339-64.

Knill, J.L. (1963) A sedimentary history of the Dalradian Series. In The British Caledonides. (eds Johnson, M.R.W. and Stewart, F.H.). Oliver and Boyd, Edinburgh, pp. 99-121.

Krabbendam, M. and Leslie, A.G. (1996) Folds with vergence opposite to the sense of shear. Journal of Structural Geology, 18, 777-81.

Krabbendam, M., Leslie, A.G., Crane, A. and Goodman, S. (1997) Generation of the Tay Nappe, Scotland, by large-scale SE-directed shearing. Journal of the Geological Society, London, 154, 15-24.

Krabbendam, M., Prave, A.R. and Cheer, D.A. (2008) A fluvial origin for the Neoproterozoic Morar Group, NW Scotland; implications for Torridon-Morar Group correlation and the Grenville Orogen foreland basin. Journal of the Geological Society, London, 165, 379-94. 
Kruhl, J. and Voll, G. (1975) Large scale pre-metamorphic and precleavage inversion at Loch Leven, Scottish Highlands. Neues Jahrbuch für Mineralogie, 2, 71-8.

Kynaston, H. and Hill J.B. (1908) The Geology of the country near oban and Dalmally. Memoir of the Geological Survey, sheet 45 (Scotland).

Lambert, R.St. J. (1975) Discussion of Moine-Dalradian relationships in the River Leven. Journal of the Geological Society of London, 131, 327-8.

Lambert, R.St.J., Holland, J.G. and Winchester, J.A. (1982) A geochemical comparison of the Dalradian Leven Schists and the Grampian Division Monadhliath Schists of Scotland. Journal of the Geological Society of London, 139, 71-84.

Lambert, R.St.J. and McKerrow, W.S. (1976) The Grampian Orogeny. Scottish Journal of Geology, 12, 271-92.

Lambert, R.St.J, Winchester, J.A. and Holland, J.G. (1981) Comparative geochemistry of pelites from the Moinian and Appin Group (Dalradian) of Scotland. Geological Magazine, $118,477-90$.

Lawson, J. D. and Weedon, D. S. (editors) (1992) Geological Excursions around Glasgow and Girvan. Geological Society of Glasgow, Glasgow.

Leake, B.E. (1982) Volcanism in the Dalradian. In Igneous rocks of the British Isles. Sutherland, D. S. (editor). John Wiley and Sons, Chichester, pp. 45-50.

Leake, B.E. and Tanner, P.W.G. (1994) The Geology of the Dalradian and Associated Rocks of Connemara, Western Ireland: a report to accompany the 1:63360 geological map and cross sections. Royal Irish Academy, Dublin.

Lee, G.W. and Bailey, E.B. (1925) The pre-Tertiary geology of Mull, Loch Aline and Oban. Memoir of the Geological Survey of Great Britain, Sheet 44 (Scotland).

Leggo, P.J., Tanner, P.W.G. and Leake, B.E. (1969) Isochron study of Donegal Granite and certain Dalradian rocks of Britain. In North Atlantic-geology and Continental Drift, a symposium (ed. M. Kay), Memoir of the American Association of Petroleum Geologists, 12, pp. 354-62.

Le Maitre, R.W (editor) (2002). Igneous Rocks: a Classification and Glossary of Terms; Recommendations of the International Union of Geological Sciences Subcommission on the Systematics of Igneous Rocks. Cambridge University Press, Cambridge, $236 \mathrm{pp}$.

Leslie, A.G., Chacksfield, B.C., Smith, M. and Smith, R.A. (1999). The Geophysical signature of a major shear zone in the Central Highlands of Scotland. British Geological Survey Technical Report No. WA/99/32R.

Leslie, A.G., Krabbendam, M. and Smith, R.A. (2006) The Gaick Fold Complex: large-scale recumbent folds and their implications for Caledonian structural architecture in the Central Grampian Highlands. Scottish Journal of Geology, 42, 149-60.

Leslie, A.G., Smith, M. and Soper, N.J. (2008) Laurentian margin evolution and the Caledonian orogeny-a template for Scotland and East Greenland. In The Greenland Caledonides: Evolution of the Northeast Margin of Laurentia. Higgins, A.K., Gilotti, J.A. and Smith, M.P. (editors), Geological Society of America Memoir, 202, 307-43. 
Lindsay, N.G. (1988) Contrasts in Caledonian tectonics of the Northern and Central Highlands. Unpublished PhD thesis, University of Liverpool.

Lindsay, N.G., Haselock, P.J. and Harris, A.L. (1989). The extent of Grampian orogenic activity in the Scottish Highlands. Journal of the Geological Society of London, 146, 733-5.

Litherland, M. (1970) The stratigraphy and structure of the Dalradian rocks around Loch Creran, Argyll. Unpublished PhD thesis, University of Liverpool.

Litherland, M. (1975) Organic remains and traces from the Dalradian of Benderloch, Argyll. Scottish Journal of Geology, 11, 47-50.

Litherland, M. (1980) The stratigraphy of the Dalradian rocks around Loch Creran, Argyll. Scottish Journal of Geology, 16, 10523 .

Litherland, M. (1982) The structure of the Loch Creran Dalradian and a new model for the SW Highlands. Scottish Journal of Geology, $18,205-25$.

Loudon, T.V. (1963) The sedimentation and structure in the Macduff District of North Banffshire and Aberdeenshire. Unpublished PhD thesis, University of Edinburgh.

Lowe, D. R. 1976. Subaqueous liquified and fluidised sediment flows and their deposits. Sedimentology, 23, pp. 285-308.

Lyubetskaya, T. and Ague, J.J., 2010. Modeling metamorphism in collisional orogens intruded by magmas: fluid flow and implications for Barrovian and Buchan metamorphism, Scotland. American Journal of Science, 310, 459-491.

McAteer, C.A., Daly, J.S., Flowerdew, M.J., Connelly, J.N., Housh, T.B. and Whitehouse, M.J. (2010) Detrital zircon, detrital titanite and igneous clast $\mathrm{U}-\mathrm{Pb}$ geochronology and basement-cover relationships of the Colonsay Group, SW Scotland: Laurentian provenance and correlation with the Neoproterozoic Dalradian Supergroup. Precambrian Research, 181, 21-42.

McCallien, W.J. (1925) Notes on the Geology of the Tarbet district of Loch Fyne. Transactions of the Geological society of Glasgow, $17,233-63$.

McCallien, W.J. (1926) The structure of South Knapdale (Argyll). Transactions of the Geological Society of Glasgow, 17, 377-94.

McCallien, W.J. (1929) The metamorphic rocks of Kintyre. Transactions of the Royal Society of Edinburgh, 56, 40936 .

Mccallien, W.J. (1938) The Geology of Bute. Transactions of the Buteshire Natural History Society, 12, 84-112.

McCay, G.A., Prave, A.R., Alsop, G.I. and Fallick, A.E. (2006) Glacial trinity: Neoproterozoic Earth history within the BritishIrish Caledonides. Geology, 34, 909-12.

McClay, K.R. (1987) The Mapping of Geological Structures. Geological Society of London Handbook, Open University Press, Milton Keynes, $161 \mathrm{pp}$.

McClay K.R., Norton M.G., Cony P. and Davis G.H. (1986) Collapse of the Caledonian Orogen and the Old Red Sandstone. Nature, London 323, 147-9.

MacCulloch, J. (1814) Remarks on several parts of Scotland which exhibit quartz rock, and on the nature and connexions of this rock in general. Transactions of the Geological Society, 2, 450-87.

MacCulloch, J. (1819) A description of the western islands of Scotland including the Isle of Man: comprising an account of their 
geological structure; with remarks on their agriculture, scenary and antiquities. 3 volumes. Constable, London.

MacDonald, J.G. and Herriot, A. (1983) Macgregor's excursion guide to the geology of Arran. (3rd edition). Geological Society of Glasgow and University of Glasgow, Glasgow.

Macdonald, R. and Fettes, D.J. (2007) The tectonomagmatic evolution of Scotland. Transactions of the Royal Society of Edinburgh: Earth Sciences, 97, 213-95.

Macdonald, R., Fettes, D.J., Stephenson, D. and Graham, C.M. (2005) Basic and ultrabasic volcanic rocks from the Argyll Group (Dalradian) of NE Scotland. Scottish Journal of Geology, 41, 15974 .

MacGregor, A.G. (1948) British regional geology: the Grampian Highlands (2nd edition), HMSO for Geological Survey and Museum, Edinburgh.

MacGregor, A.R. (1996) Edzell and Glen Esk. 93-108 in Fife and Angus Geology, an excursion guide (3rd edition) by A.R. MacGregor, Pentland Press, Durham.

MacGregor, S.M.A. and Roberts, J.L. (1963) Dalradian pillow lavas, Ardwell Bridge, Banffshire. Geological Magazine, 100, 17-23.

McIntyre, D.B. (1950) Lineation, boudinage and recumbent folding in the Struan Flags (Moine), near Dalnacardoch, Perthshire. Geological Magazine, 87, 205-25.

McIntyre, D.B. (1951) The tectonics of the area between Grantown and Tomintoul (mid-Strathspey). Quarterly Journal of the Geological Society of London, 107, 1-22.

McKenzie, D.P. and Bickle, M.J. (1988). The volume and composition of melt generated by the extension of the lithosphere. Journal of Petrology, 29, 625-79.

McKie, T. (1990) Tidal and storm-influenced sedimentation from a Cambrian transgressive passive margin sequence. Journal of the Geological Society, London, 147, 785-94.

Mackie, W. (1908) Evidence of contemporaneous volcanic action in the Banffshire schists. Transactions of the Edinburgh Geological Society, 9, 93-101.

McLellan, E.L. (1983) Barrovian migmatites and the thermal history of the south-eastern Grampians. Unpublished PhD thesis, University of Cambridge.

McLellan, E.L., 1985. Metamorphic reactions in the kyanite and sillimanite zones of the Barrovian type area, Journal of Petrology, 26, 789-818.

Macnair, P. (1896) The altered clastic rocks of the Southern Highlands: their structure and succession. Geological Magazine, Decade 4, 3, 167-174, 211-217.

Macnair, P. (1906) On the development of the great axial lines of folding in the Highland schists. Proceedings of the Royal Philosophical Society of Glasgow Vol. 37, 129-xxx.

Macnair, P. (1908) The Geology and Scenery of the Grampians and the Valley of Strathmore, James MacLehose and Sons, Glasgow, 2 volumes, $256 \mathrm{pp}$.

Marcantonio, F., Dickin, A.P., McNutt, R.H. and Heaman, L.M. (1988). A 1880-million year old Proterozoic gneiss terrane in Islay with implications for crustal evolution of Britain. Nature, $335,62-64$.

Mather, J.D. (1968) A geochemical, mineralogical and petrological study of rocks of lower greenschist facies from the Dalradian of Scotland. Unpublished PhD thesis, University of Liverpool. 
May, F. (1970) Movement, metamorphism and migmatization in the Scalloway region of Shetland. Bulletin of the Geological Survey of Great Britain, 31, 205-26.

May, F. and Highton, A.J. (1997) Geology of the Invermoriston district. Memoir of the British Geological Survey. Sheet 73W (Scotland).

Melezhik, V.A., Gorokhov, I.M., Kuznetsov, A.B. and Fallick, A.E. (2001). Chemostratigraphy of Neoproterozoic carbonates: implications for 'blind dating'. Terra Nova, 13, 1-11.

Mendum, J.R. 1987. Dalradian of the Collieston coast section. 161172 in Excursion guide to the geology of the Aberdeen area. Trewin, $\mathrm{N}$ H, Kneller, B C, and Gillen, C (editors). (Edinburgh: Scottish Academic Press for Geological Society of Aberdeen.)

Mendum, J.R., Barber, A.J., Butler, R.W.H., Flinn, D., Goodenough, K.M., Krabbendam, M., Park, R.G. and Stewart, A.D. (2009) Lewisian, Torridonian and Moine rocks of Scotland, Geological Conservation Review Series, No. 34, Joint Nature Conservation Committee, Peterborough, $722 \mathrm{pp}$.

Mendum, J.R. and Fettes, D.J. (1985) The Tay nappe and associated folding in the Ben Ledi-Loch Lomond area. Scottish Journal of Geology, 21, 41-56.

Mendum, J.R. and Noble, S.R. (2010) Mid-Devonian sinistral transpression on the Great Glen Fault: the rise of the Rosemarkie Inlier and the Acadian Event in Scotland. In Continental tectonics and mountain building: the legacy of Peach and Horne. (eds R.D. Law, R.W.H. Butler, R.E. Holdsworth, M. Krabbendam and R.A. Strachan), Geological Society, London, Special Publication, No. 335, pp. 161-187.

Mendum, J.R. and Thomas, C.W. (1997) Discussion on the generation of the Tay Nappe, Scotland, by large-scale SE-directed shearing. Journal of the Geological Society, London, 154, 581-3.

Miall, A. D. 1985. Architectural-element analysis: a new method of facies analysis applied to fluvial deposits. Earth Science Reviews, 22, pp. 261-308.

Miall, A. D. 1992. Alluvial Deposits. In: Walker, R. G. \& James, N. P. (eds), Facies models - response to sea level changes. Geoscience Canada, pp. 119-1992.

Millar, I.L. (1999) Neoproterozoic extensional basic magmatism associated with the West Highland granite gneiss in the Moine Supergroup of NW Scotland. Journal of the Geological society, London 156, 1153-62.

Moffat, D.T. (1987) The serpentinized ultramafites of the Shetland Caledonides. Unpublished PhD thesis, University of Liverpool.

Moig, N.A.W. (1986) A structural study of the Dalradian rocks of the Banff coastal transect, NE Scotland. Unpublished PhD thesis, University of Dundee.

Moles, N.R. (1985a) Geology, geochemistry and petrology of the Foss stratiform baryte-base metal deposit and adjacent Dalradian metasediments, near Aberfeldy. Unpublished PhD thesis, University of Edinburgh.

Moles, N.R. (1985b) Metamorphic conditions and uplift history in central Perthshire: evidence from mineral equilibria in the Foss celsian-barite-sulphide deposit, Aberfeldy. Journal of the Geological Society of London, 142, 39-52. 
Möller, C. (1998) Decompressed eclogites in the Sveconorwegian (Grenvilian) Orogen of SW Sweden; petrology and tectonic implications. Journal of Metamorphic Geology, 16, 641-56.

Molyneux, S.G. 1998. An upper Dalradian microfossil reassessed. Journal of the Geological Society, London, 155, 740-743.

Morgan, W.C. (1966) The metamorphic history of the Dalradian rocks between Tomintoul and Loch Builg, Banfshire. Unpublished Ph D thesis, University of Aberdeen.

Morris, G.A. and Hutton, D.H.W. (1993) Evidence for sinistral shear associated with the emplacement of the early Devonian Etive dyke swarm. Scottish Journal of Geology, 29, 69-72.

Mould, D.D.C.P. (1946) The geology of the Foyers 'granite' and the surrounding country. Geological Magazine, 83, 249-65.

Muir, R.J. (1990) The Precambrian basement and related rocks of the southern Inner Hebrides, Scotland. Unpublished PhD thesis, University of Wales, Aberystwyth.

Muir, R.J., Fitches, W.R. and Maltman, A.J. (1989) An Early Proterozoic link between Greenland and Scandinavia in the Inner Hebrides of Scotland. Terra Abstract, 1, 5.

Muir, R.J., Fitches, W.R. and Maltman, A.J. (1992). Rhinns Complex: a missing link in the Proterozoic basement of the North Atlantic region. Geology, 20, 1043-6.

Muir, R.J., Fitches, W.R. and Maltman, A.J. (1994a). The Rhinns Complex: Proterozoic basement on Islay and Colonsay, Inner Hebrides, Scotland, and on Inishtrahull, NW Ireland. Transactions of the Royal Society of Edinburgh: Earth Sciences, 85, 77-90.

Muir, R.J., Fitches, W.R., Maltman, A.J. and Bentley, M.R. (1994b) Precambrian rocks of the southern Inner Hebrides-Malin Sea region: Colonsay, west Islay, Inishtrahull and Iona. In: Gibbons, W. and Harris, A.L. (eds) A revised correlation of Precambrian rocks in the British Isles. Geological Society, London, Special Report 22, 54-58.

Muir, R.J., Fitches, W.R. and Maltman, A.J. (1995). The Colonsay Group and basement-cover relationship on the Rhinns of Islay, Inner Hebrides. Scottish Journal of Geology, 31, 125-30.

Munro, M. (1986) Geology of the country around Aberdeen. Memoir of the British Geological Survey, sheet 77 (Scotland).

Munro, M. and Gallagher, J W. (1984) Disruption of the 'Younger Basic' masses in the Huntly-Portsoy area, Grampian Region. Scottish Journal of Geology, 20, 361-82.

Murchison, R.I. (1851) on the Silurian rocks of the south of Scotland. Quarterly Journal of the Geological Society of London, 7, 139-78.

Murchison, R.I. (1859) Siluria: the History of the Oldest known Rocks Containing Organic Remains, With a Brief Sketch of the Distribution of Gold Over the Earth. 3rd edition. John Murray, London.

Murchison, R.I. and Geikie, A. (1861) On the altered rocks of the Western Islands of Scotland and the North-Western and Central Highlands. Quarterly Journal of the Geological Society of London 17, 171- ??.

Mutti, E. and Normark, W.R. (1987) Comparing examples of modern and ancient turbidite systems: problems and concepts. In Marine Clastic Sedimentology (eds. Legget, J.K and Zuffa, G.G.), Graham and Trotman, pp.1-38.

Mykura, W. (1976) British Regional Geology: Orkney and Shetland. HMSO, Edinburgh for the Institute of Geological Sciences. 
Nell, P.A.R. (1984) The geology of lower Glen Lyon. Unpublished PhD thesis, University of Manchester.

Nell, P.A.R. (1986) Discussion on the Caledonian metamorphic core: an Alpine model. Journal of the Geological Society of London, $143,723-8$.

Nesbitt, R.W. and Hartmann, L.A. (1986) Comments on 'A peridotitic komatiite from the Dalradian of Shetland' by D. Flinn and D.T. Moffat. Geological Journal, 21, 201-5.

Nicol, J. (1844) Guide to the geology of Scotland: Containing an Account of the Character, Distribution and More Interesting Appearances of its Rocks and Minerals. Oliver and Boyd, Edinburgh.

Nicol, J. (1852) on the geology of the southern portion of the peninsula of Cantyre, Argyllshire. Quarterly Journal of the Geological Society of London, 8, 406-25.

Nicol J. (1863) On the geological structure of the Southern Grampians. Quarterly Journal of the Geological Society of London $19,180-209$.

Noble, S.R., Hyslop, E.K. and Highton, A.J. (1996). High-precision $\mathrm{U}-\mathrm{Pb}$ monazite geochronology of the c. 806 Ma Grampian Shear Zone and the implications for evolution of the Central Highlands of Scotland. Journal of the Geological Society, London, 153, 511-14.

Okonkwo, C.T. (1985). The geology and geochemistry of the metasedimentary rocks of the Loch Laggan-Upper Strathspey area, Inverness-shire. Unpublished PhD thesis, University of Keele.

Okonkwo, C.T. (1988). The stratigraphy and structure of the metasedimentary rocks of the Loch Laggan-Upper Strathspey area, Inverness-shire. Scottish Journal of Geology, 24, 21-34.

Oldroyd, D.R. and Hamilton, B.M. (2002) Themes in the early history of Scottish geology. In: Trewin N. H. (ed.) The Geology of Scotland. The Geological Society, London, pp. 27-43.

Oliver, G.J.H. (2001) Reconstruction of the Grampian episode in Scotland: its place in the Caledonian Orogeny. Tectonophysics, $332,23-49$.

Oliver, G.J.H. (2002) Chronology and terrane assembly, new and old controversies. In The Geology of Scotland (edited by Trewin, N. H.) The Geological Society, London, 201-11.

Oliver, G.J.H., Chen, F., Buchwald, R. and Hegner, E. (2000) Fast tectonometamorphism and exhumation in the type area of the Barrovian and Buchan zones. Geology, 28, 459-62.

Oliver, G.J.H., Simon, A.W., Wan, Y., 2008. Geochronology and geodynamics of Scottish granitoids from the late Neoproterozoic break-up of Rodinia to Palaeozoic collision. Journal of the Geological Society, London, 165, 661-674.

Pankhurst, R.J. (1970) The geochronology of the basic igneous complexes. Scottish Journal of Geology, 6, 83-107.

Pankhurst, R.J. and Pidgeon, R.T. (1976) Inherted isotope systems and the source region prehistory of the early Caledonian granites in the Dalradian Series of Scotland. Earth and Planetary Science Letters, 31, 58-66.

Pantin, H.M. (1952) Part 1: The petrology and structure of the Ben Vrackie epidiorite. Part 2: Some new observations on Dalradian stratigraphy and tectonics. Unpublished PhD thesis, University of Cambridge. 
Pantin H.M. (1961) The stratigraphy and structure of the Blair Atholl-Ben a' Gloe area, Perthshire, Scotland. Transactions of the Royal Society of New Zealand, 88, 597-622.

Park, R.G. (1992) Plate kinematic history of Baltica during the Middle to Late Proterozoic: a model. Geology 20, 725-8.

Park, R.G. (1994) Early Proterozoic tectonic overview of the northern British Isles and neighbouring terrains in Laurentia and Baltica. Precambrian Research, 68, 65-79.

Parson, L M. (1982) The Precambrian and Caledonian geology of the ground near Fort Augustus, Inverness-shire. Unpublished PhD thesis, University of Liverpool.

Paterson, I.B., Hall, I.H.S. and Stephenson, D. (1990) Geology of the Greenock district. Memoir of the British Geological Survey, Sheet 30W and part of sheet 29E (Scotland).

Pattrick, R.A. and Treagus, J.E. (1996) Economic geology of the Schiehaliion district, central highlands of Scotland. British Geological Survey Technical Report No. WA/96/89.

Peach, B.N. (1904) Summary of Progress of the Geological Survey of the United Kingdom for 1903, 69.

Peach, B.N. and Horne, J. (1930) Chapters on the Geology of Scotland, Oxford University Press, London.

Peach, B.N., Kynaston, B.A. and Muff, H.B. (1909) The geology of the seaboard of mid Argyll including the islands of Luing, Scarba, the Garvellachs, and the Lesser Isles, together with the northern part of Jura and a small portion of Mull. Memoirs of the Geological Survey of Scotland, sheet 36 .

Peach, B.N., Wilson, J.G.S., Hill, J.B., Bailey, E.B. and Grabham, G.W. (1911) The Geology of Knapdale, Jura and North Kintyre. Memoirs of the Geological Survey of Scotland, Sheet 28.

Peach, B.N. and Horne, J. (1930) Chapters on the Geology of Scotland, Oxford University Press, Oxford.

Peacock, J.D., Berridge, N.G., Harris, A.L. and May, F. (1968) The geology of the Elgin district. Memoir of the Geological Survey of Scotland, sheet 95 (Scotland).

Phillips, E.R. (1996) The mineralogy and petrology of the igneous and metamorphic rocks exposed in the Macduff district (Sheet 96E), Northeast Scotland. British Geological Survey, Mineralogy and Petrology Technical Report, WG/96/26.

Phillips, E.R. and Auton, C.A. (1997) Ductile fault rocks and metamorphic zonation in the Dalradian of the Highland Border SW of Stonehaven, Kincardineshire. Scottish Journal of Geology, 33, 8393.

Phillips, E.R., Clark, G.C. and Smith, D.I. (1993) Mineralogy, petrology, and microfabric analysis of the Eilrig shear Zone, Fort Augustus, Scotland. Scottish Journal of Geology, 29, 143-58.

Phillips, E.R., Hyslop, E.K., Highton, A.J and Smith, M. (1999). The timing and $\mathrm{P}-\mathrm{T}$ conditions of regional metamorphism in the Central Highlands. Journal of the Geological Society, London, 156, $1183-93$.

Phillips, F.C. (1930) Some mineralogical and chemical changes induced by progressive metamorphism in the Green Bed group of the Scottish Dalradian. Journal of the Mineralogical Society, 22, $240-$ 256 .

Phillips, F.C. (1954) The Use of Stereographic Projection in Structural Geology, Arnold, London. 
Phillips, W.E.A., Stillman, C.J. and Murphy, T. (1976) A Caledonian plate tectonic model. Journal of the Geological Society of London, 132 , 579-609.

Piasecki M.A.J. (1975) Tectonic and metamorphic history of the Upper Findhorn, Inverness-shire, Scotland. Scottish Journal of Geology, 11, 87-115.

Piasecki, M.A.J. (1980). New light on the Moine rocks of the Central Highlands of Scotland. Journal of the Geological Society of London, 137, 41-59.

Piasecki, M.A.J. and van Breemen, O. (1979a) A Morarian age for the "younger Moines" of central and western Scotland. Nature, London, 278, 734-6.

Piasecki, M.A.J. and van Breemen, O. (1979b). The 'Central Highland Granulites': cover-basement tectonics in the Moine. In The Caledonides of the British Isles - reviewed. (editors. Harris, A.L., Holland, C.H. and Leake, B.E.), The Geological Society of London, Special Publications, 8, 139-44.

Piasecki, M.A.J. and van Breemen, O. (1983) Field and isotopic evidence for a c. 750 Ma tectonothermal event in Moine rocks in the Central Highland region of the Scottish Caledonides. Transactions of the Royal Society of Edinburgh: Earth Sciences, 73, 119-34.

Piasecki, M.A.J., van Breemen, O. and Wright, A.E. (1981) Late Precambrian geology of Scotland, England and Wales. In Geology of the North Atlantic Borderlands, Kerr, J.W. and Fergusson, A.J. (eds). Memoir of the Canadian Society of Petroleum Geologists, 7, 57-94.

Piasecki, M.A.J. and Temperley, S. (1988a). The Central Highland Division. In: Winchester, J.A. (ed) Later Proterozoic stratigraphy of the Northern Atlantic regions. Blackie, Glasgow and London, 4653 .

Piasecki, M.A.J. and Temperley, S. (1988b). The northern sector of the central Highlands. 51-68 in An excursion guide to the Moine geology of the Scottish Highlands. Allison, I, May, F, and Strachan, R A (editors). (Edinburgh: Scottish Academic Press for Edinburgh Geological Society and Geological Society of Glasgow.)

Pickering K.T., Bassett M.G., and Siveter D.J. (1988) Late Ordovician-early Silurian destruction of the Iapetus Ocean: Newfoundland, British Isles and Scandinavia: A discusion. Transactions of the Royal Society of Edinburgh: Earth Sciences, 79, 361-82.

Pickett, E.A. (1997) An introduction to the Green Beds of the Southern Highland Group: previous research and an account of preliminary work carried out in 1997. British Geological Survey Technical Report WA/97/92.

Pickett, E.A., Hyslop, E.K. and Petterson, M.G. (2006) The Green Beds of the SW Highlands: deposition and origin of a basic igneous-rich sedimentary sequence in the Dalradian supergroup of Scotland. Scottish Journal of Geology, 42, 43-57.

Pidgeon R.T. and Compston W. (1992) A Shrimp ion microprobe study of inherited and magmatic zircon from Scottish Caledonian granites. Transactions of the Royal Society, Edinburgh: Earth Sciences, 83, 473-83.

Pitcher, W.S. and Berger, A.R. (1972) The Geology of Donegal: a study of granite emplacement and unroofing. Wiley-Interscience, New York, $435 \mathrm{pp}$. 
Plant, J.A., Stone, P. and Mendum, J.R. (1999) Regional geochemistry, terrane analysis and metallogeny in the British Caledonides. In Continental Tectonics. MacNiocaill, C and Ryan, P.D. (editors), Geological Society, London, Special Publication No $164,109-26$.

Plant, J.A., Watson, J.V. and Green, P.M. (1984) Moine-Dalradian relationships and their palaeotectonic significance. Proceedings of the Royal Society, 395a, 185-202.

Powell, R. and Evans, J.A. (1983). A new geobarometer for the assemblage biotite-muscovite-chlorite-quartz. Journal of Metamorphic Geology, 1, 331-6.

Power, M.R. and Pirrie, D. (2000) Platinum-group mineralization within ultramafic rocks at Corrycharmaig, Perthshire: implications for the origin of the complex. Scottish Journal of Geology, 36, $143-50$.

Prave, A.R. (1999) The Neoproterozoic Dalradian Supergroup of Scotland: an alternative hypothesis. Geological Magazine, 136, 609-17.

Prave, A.R., Fallick, A.E., Thomas, C.W. and Graham, C.M. (2009a) A composite C-isotope profile for the Neoproterozoic Dalradian Supergroup of Scotland and Ireland. Journal of the Geological Society, 166, 845-857.

Prave, A.R., Strachan, R.A. and Fallick, A.E. (2009b) Global C cycle perturbations recorded in marbles: a record of Neoproterozoic Earth history within the Dalradian succession of the Shetland Islands, Scotland. Journal of the Geological Society, 166, 129-135.

Pringle, I.R. (1972) Rb-Sr age determinations on shales associated with the Varanger Ice Age. Geological Magazine, 109, $465-72$.

Pringle, J. (1940) The discovery of Cambrian trilobites in the Highland Border rocks near Callander, Perthshire (Scotland). British Association for the Advancement of Science: Annual Report for 1939-40, 1, 252 .

Pumpelly, R., Wolff, J.E. and Dale, T.N. (1894) Geology of the Green Mountains. United States Geological Survey Memoir, 23, 1157 .

Rainbird, R.H., Hamilton, M.A. and Young, G.M. (2001) Detrital zircon geochronology and provenance of the Torridonian, NW Scotland. Journal of the Geological Society, London, 158, 15-27.

Ramsay, D.M. (1959) Structure and metamorphism of Glen Lyon. Unpublished PhD thesis, University of Glasgow.

Ramsay, D.M. and Sturt, B.A. (1979) The status of the Banff Nappe. In The Caledonides of the British Isles-reviewed. Harris, A L, Holland, C H and Leake, B E (editors). Special Publication of the Geological Society of London, No. 8. 145-151

Ramsay, J.G. (1958) Moine-Lewisian relations at Glenelg, Invernessshire. Quarterly Journal of the Geological Society of London 113, $487-523$.

Rast, N. (1956) Tectonics of Central Perthshire. Unpublished PhD thesis, University of Glasgow.

Rast, N. (1958) Metamorphic history of the Schiehallion complex, Perthshire. Transactions of the Royal Society of Edinburgh, 64, 413-31. 
Rast, N. (1963). Structure and metamorphism of the Dalradian rocks of Scotland. In The British Caledonides. (editors. Johnson, M.R.W. and Stewart, F.H.). Oliver and Boyd, Edinburgh, 123-42.

Rast, N. and Litherland, M. (1970) The correlation of the Ballachulish and Perthshire (Islay) successions. Geological Magazine, 107, 259-72.

Read, H.H. (1919) The two magmas of Strathbogie and Lower Banffshire. Geological Magazine 56, 364-71.

Read, H.H. (1923) The geology of the country around Banff, Huntly, and Turriff, Lower Banffshire and north-west Aberdeenshire. Memoir of the Geological Survey, Scotland. Sheets 86 and 96 (Scotland).

Read, H.H. (1927) The igneous and metamorphic history of Cromar, Deeside. Transactions of the Royal Society of Edinburgh, 55, 31753.

Read, H.H. (1928) The Highland Schists of middle Deeside and east Glen Muick. Transactions of the Royal Society of Edinburgh, 55, $755-72$.

Read, H.H. (1933). On quartz-kyanite rocks in Unst, Shetland Islands, and their bearing on metamorphic differentiation. Mineralogical Magazine, 23, 317-28.

Read, H.H. (1934) The metamorphic geology of Unst in the Shetland Islands. Quarterly Journal of the Geological Society of London 90, 637-88.

Read, H.H. (1935) British Regional Geology: the Grampian Highlands (1st edition). HMSO for Geological Survey and Museum, Edinburgh.

Read, H.H. (1936) The stratigraphical order of the Dalradian rocks of the Banffshire coast. Geological Magazine, 73, 468-75.

Read, H.H. (1937) Metamorphic correlation in the polymetamorphic rocks of the Valla Field Block, Unst, Shetland Islands. Transactions of the Royal Society of Edinburgh, 59, 195-221.

Read, H.H. (1952) Metamorphism and migmatisation in the Ythan Valley, Aberdeenshire. Transactions of the Edinburgh Geological Society, 15, 265-79.

Read, H.H. (1955) The Banff nappe: an interpretation of the structure of the Dalradian rocks of north-east Scotland. Proceedings of the Geologists' Association, 66, 1-29.

Read, H.H. (1960) North-east Scotland: the Dalradian. Geologists' Association Guide, 31. Benham and Co., Colchester.

Read, H.H. and Farquhar, O.C. (1956) The Buchan Anticline of the Banff Nappe of Dalradian rocks in north-east Scotland. Quarterly Journal of the Geological Society of London, 112, 131-56.

Richardson, S.W. and Powell, R. (1976) Thermal causes of the Dalradian metamorphism in the Central Highlands of Scotland. Scottish Journal of Geology, 12, 237-68.

Ritchie, J.D. and Hitchen, K. (1993) Discussion on the location and history of the Walls Boundary fault and Moine thrust north and south of Shetland. Journal of the Geological Society, London, 150, $1003-8$.

Roberts, J.L. (1959) Fold Structures in the Dalradian Rocks of Knapdale, Argyllshire. Geological Magazine, 94, 221-9.

Roberts, J.L. (1963) The Dalradian of the southwest highlands of Scotland. Unpublished PhD thesis, University of Liverpool.

Roberts, J.L. (1966a) Sedimentary affiliations and stratigraphic correlation of the Dalradian rocks in the South-west Highlands of Scotland. Scottish Journal of Geology, 2, 200-23.

Roberts, J.L. (1966b) The formation of similar folds by inhomogeneous plastic strain, with reference to the fourth phase 
of deformation affecting the Dalradian rocks in the southwest Highlands of Scotland. Journal of Geology, 74, 831-55.

Roberts, J.L. (1974) The structure of the Dalradian rocks in the SW Highlands of Scotland. Journal of the Geological Society of London, 130, 93-124.

Roberts, J.L. (1976) The structure of the Dalradian rocks in the north Ballachulish district of Scotland. Journal of the Geological Society of London, 132, 139-54.

Roberts, J.L. (1977a) The evolution and transport of the Tay Nappe: Discussion. Scottish Journal of Geology, 13, 79-80.

Roberts, J.L. (1977b) The Dalradian rocks of Rosneath and Southeast Cowal. Scottish Journal of Geology, 13, 101-11.

Roberts, J.L. (1977C) The Dalradian rocks of Knapdale and North Kintyre. Scottish Journal of Geology, 13, 113-124.

Roberts, J.L. and Sanderson, D.J. (1974) Oblique fold axes in the Dalradian rocks of the Southwest Highlands. Scottish Journal of Geology, 9, 281-96.

Roberts, J.L. and Treagus, J.E. (1964) A reinterpretation of the Ben Lui Fold. Geological Magazine, 101, 512-16.

Roberts, J.L, and Treagus, J.E. (1975) The structure of the Moine and Dalradian rocks in the Dalmally district of Argyllshire, Scotland. Geological Journal, 10, 59-74.

Roberts, J.L, and Treagus, J.E. (1977a) The Dalradian rocks of the South-west Highlands-Introduction. Scottish Journal of Geology, Vol. 13, 87-99.

Roberts, J.L. and Treagus, J.E. (1977b) The Dalradian rocks of the Loch Leven area. Scottish Journal of Geology, 13, 165-184.

Roberts, J.L. and Treagus, J.E. (1977C) Polyphase generation of nappe structures in the Dalradian rocks of the Southwest Highlands of Scotland. Scottish Journal of Geology. 13, 237-254.

Roberts, J.L, and Treagus, J.E. (1979) Stratigraphical and structural correlation between the Dalradian rocks of the $\mathrm{SW}$ and Central Highlands of Scotland. 199-204 in The Caledonides of the British Isles-reviewed. Harris, A.L., Holland, C.H., and Leake, B.E. (editors). Special Publication of the Geological Society of London. 8 .

Roberts, J.L, and Treagus, J E. (1980) The structural interpretation of the Loch Leven area. Scottish Journal of Geology, 16, 73-5.

Robertson, S. (1991) Older granites in the south-eastern Scottish Highlands. Scottish Journal of Geology, 27, 21-6.

Robertson, S. (1994) Timing of Barrovian metamorphism and 'older Granite' emplacement in relation to Dalradian deformation. Journal of the Geological Society of London, 151, 5-8.

Robertson, S. (1999) BGS Rock Classification Scheme Volume 2: Classification of metamorphic rocks. British Geological Survey Research Report, RR 99-02.

Robertson, S. and Smith, M. (1999) The significance of the Geal charn-Ossian steep Belt in basin development in the Central Scottish Highlands. Journal of the Geological Society, London, 156, 1175-82.

Rock, N.M.S. (1985) A compilation of analytical data for metamorphic limestones from the Scottish Highlands and Islands, with lists of BGS registered samples, and comments on the reproducibility and accuracy of limestone analyses by different analytical techniques. Mineralogical and Petrological Report British Geological Survey, No. 85/5. 
Rock, N.M.S. (1986) Chemistry of the Dalradian (Vendian-Cambrian) metalimestones, British Isles. Chemical Geology, 56, 289-311.

Rock, N.M.S., Macdonald, R. and Bower, J. (1986) The comparative geochemistry of some Highland pelites (Anomalous local limestonepelite successions within the Moine outcrop; II). Scottish Journal of Geology, 22, 107-26.

Rogers, G., Dempster, T.J., Bluck, B.J. and Tanner, P.W.G. (1989) A high precision $\mathrm{U}-\mathrm{Pb}$ age for the Ben Vuirich Granite: implications for the evolution of the Scottish Dalradian Supergroup. Journal of the Geological Society, London, 146, 789-98.

Rogers, G., Hyslop, E.K., Strachan, R.A., Paterson, B.A. and Holdsworth, R.A. (1998) The structural setting and U-Pb geochronology of the Knoydartian pegmatites of $W$ Inverness-shire: evidence for Neoproterozoic tectonothermal events in the Moine of NW Scotland. Journal of the Geological Society, London, 155, 68596 .

Rogers, G., Kinny, P.D., Strachan, R.A., Friend, C.R.L. and Patterson, B.A. (2001) U-Pb geochronology of the Fort Augustus granite gneiss, constraints on the timing of Neoproterozoic and Paleozoic tectonothermal events in the NW Highlands of Scotland. Journal of the Geological Society, London, 158, 7-14.

Rogers, G. and Pankhurst, R.J. (1993) Unravelling dates through the ages: geochronology of the Scottish metamorphic complexes. Journal of the Geological Society, London, 150, 447-64.

Rollin, K.E. (1994) Geophysical correlation of Precambrian rocks in northern Britain. In A Revised Correlation of Precambrian Rocks in the British Isles. Gibbons, W. and Harris, A.L. (eds.) Geological Society, London, Special Report, 22, 65-74.

Rooney, A.D., Chew, D.M. and Selby, D. (2011) Re - Os geochronology of the Neoproterozoic - Cambrian Dalradian Supergroup of Scotland and Ireland: implications for Neoproterozoic stratigraphy, glaciations and Re - Os systematics. Precambrian Research,

Rose, P.T.S. (1989) The emplacement of the Tay Nappe Scotland. Unpublished PhD thesis, University of Liverpool.

Rose, P.T.S. and Harris, A.L. (2000) Evidence for the lower Palaeozoic age of the Tay Nappe; the timing and nature of Grampian events in the Scottish Highland sector of the Laurentian margin. Journal of the Geological Society, London, 157, 789-98.

Rushton, A.W.A., Owen, A.W., Owens, R.M. and Prigmore, J.K. (1999) British Cambrian and Ordovician stratigraphy, Geological Conservation Review Series No. 18, Joint Nature Conservation Committee, Peterborough.

Russell, M.J., Hall, A.J., Willan, R.C.R., Allison, I., Anderton, R., and Bowes, G. (1984) On the origin of the Aberfeldy celsiantbarite+base metals deposits, Scotland. In Prospecting in areas of glaciated terrain, 1984. Institution of Mining and Metallurgy, London, pp. 159-170.

Ryan, P.D. and Soper, N.J. (2001) Modelling anatexis in intracratonic basins: an example from the Neoproterozoic rocks of the Scottish Highlands. Geological Magazine, 138, 577-588.

Ryan, P.D., Soper, N.J., Snyder, D.B., England, R.W. and Hutton, D.H.W. (1995) The Antrim - Galway Line: a resolution of the Highland Border Fault enigma of the Caledonides of Britain and Ireland. Geological Magazine, 132, 171-184. 
Saha, D. (1989) The Caledonian Loch Skerrols Thrust, SW Scotland: Microstructure and Strain. Journal of Structural Geology, 11, 553568 .

Schermerhorn, L.J.G. (1974) Late Precambrian mixtites: glacial and/or non-glacial? American Journal of Science, 274, 673-824.

Schermerhorn, L.J.G. (1975) Tectonic framework of Late Precambrian supposed glacials. In Ice Ages: Ancient and Modern (eds. Wright, A.E. and Moseley, F.), proceedings of the Inter-University Geological Congress (University of Birmingham) (1974), Geological Journal special issue No. 6, 242-247.

Scott, R.A. (1987) Lithostratigraphy, structure and mineralization of the Argyll Group Dalradian near Tyndrum, Scotland. Unpublished PhD thesis, University of Manchester.

Scott, R.A., Pattrick, R.A.D., and Polya, D.A. (1991) Origin of sulphur in metamorphosed stratabound mineralization from the Argyll Group Dalradian of Scotland. Transactions of the Royal Society of Edinburgh: Earth Sciences, Vol. 82, 91-98.

Scott, R.A., Polya, D.A., and Pattrick, R.A.D. (1988) Proximal Cu + Zn exhalites in the Argyll Group Dalradian, Creag Bhocan, Perthshire. Scottish Journal of Geology, Vol. 24, 97-112.

Seranne, M. (1992) Devonian extensional tectonics versus Carboniferous inversion in the northern Orcadian basin. Journal of the Geological Society, London, 149, 27-37.

Shackleton, R. M. 1958. Downward-facing structures of the Highland Border. Quarterly Journal of the Geological Society, London, 113, $361-392$.

Shackleton, R.M. (1979) The British Caledonides: comments and summary. 299-304 in The Caledonides of the British Islesreviewed. Harris, A L, Holland, C H, and Leake, B E (editors). Special Publication of the Geological Society of London, No. 8 .

Shearman, D.J. and Smith, A.J. (1985) Ikaite, the parent mineral of jarrowite-type pseudomorphs. Proceedings of the Geologists' Association, 96, 305-314.

Sibson, R.H. (1977) Fault rocks and fault mechanisms. Journal of the Geological Society, London, Vol 133, 191-213.

Simpson, A. and Wedden, D. (1974) Downward-facing structures in the Dalradian Leny Grits on Bute. Scottish Journal of Geology, 10, $257-267$.

Skelton, A.D.L. (1993) Petrological, geochemical and field studies of fluid infiltration during regional metamorphism of the Dalradian of the SW Scottish Highlands. Unpublished PhD thesis, University of Edinburgh.

Skelton, A.D.L., Bickle, M.J. and Graham, C.M. (1997) Fluid-flux and reaction rate from advective-diffusive carbonation of mafic sill margins in the Dalradian, southwest Scottish Highlands. Earth and Planetary Science Letters, 146, 527-539

Skelton, A.D.L., Graham, C.M. and Bickle, M.J. (1995) Lithological and structural constraints on regional 3-D fluid flow patterns during greenschist facies metamorphism of the Dalradian of the SW Highlands. Journal of Petrology, 36, 563-586.

Skevington, D. (1971) Palaeontological evidence bearing on the age of the Dalradian deformation and metamorphism in Ireland and Scotland. Scottish Journal of Geology, Vol. 7, 285-288.

Smallwood, J.R. (2007) Maskelyne's 1774 Schiehallion experiment revisited. Scottish Journal of Geology, Vol. 43, 15-31.

Smith, A.J. and Rast, N. (1958) Sedimentary dykes in the Dalradian of Scotland. Geological Magazine 95, $234-240$. 
Smith, C.G., Gallagher, M.J., Coats, J.S. and Parker, M.E. (1984) Detection and general characteristics of stratabound mineralization in the Dalradian of Scotland. Transactions of the Institution of Mining and Metallurgy (Section B: Applied Earth Science), Vol. 93, B125-133.

Smith, C.G., Gallagher, M.J., Grout, A., Coats, J.S., Vickers, B.P., Peachey, D., Pease, S.F., Parker, M.E. and Fortey, N.J. (1988) Stratabound base-metal materialisation in Dalradian rocks near Tyndrum, Scotland. Mineral Reconnaissance Programme Report, British Geological Survey, No. 93.

Smith, C.G., Goodman, S. and Robertson, S. (2002) Geology of the Ballater district. Memoir of the British Geological Survey, sheet 65E (Scotland).

Smith, M., Robertson, S. and Rollin, K.E. (1999) Rift basin architecture and stratigraphical implications for basement-cover relationships in the Neoproterozoic Grampian Group of the Scottish Caledonides. Journal of the Geological Society, London, 156, 11631173.

Smith, R.A. (1980) The Geology of the Dalradian rocks around Blair Atholl, Central Perthshire, Scotland. Unpublished PhD thesis, University of Liverpool.

Smith, R.A. and Harris, A, L. (1976) The Ballachulish rocks of the Blair Atholl District. Scottish Journal of Geology, Vol. 12, 153157.

Smith, T.E. (1968) Tectonics in Upper Strathspey, Inverness-shire. Scottish Journal of Geology, 4, 68-84.

Snyder, D.B. and Flack, C.A. (1990) A Caledonian age for reflectors within the mantle lithosphere north and west of Scotland. Tectonics, 9, 903-922.

Soper N.J. (1994) Was Scotland a Vendian RRR junction? Journal of the Geological Society, London, 151, 579-582.

Soper N.J. (1994) Neoproterozoic sedimentation on the northeast margin of Laurentia and the opening of Iapetus. Geological Magazine, 131, 291-299.

Soper, N.J. and Anderton, R. (1984) Did the Dalradian slides originate as extensional faults? Nature, London, Vol. 307, 357360 .

Soper, N.J. and England, R.W. (1995) Vendian and Riphean rifting in NW Scotland. Journal of the Geological Society, London 152, 11-14.

Soper, N.J. and Evans, J.A., 1997. Discussion on metamorphism and cooling of the NE Dalradian. Journal of the Geological Society, London. 154, 357-360.

Soper N.J. and Hutton D.H.W. (1984) Late Caledonian sinistral displacements in Britain: Implications for a three-plate collision model. Tectonics 3, 781-794.

Soper, N.J., Ryan, P.D. and Dewey, J.F. (1999) Age of the Grampian Orogeny in Scotland and Ireland. Journal of the Geological Society, London 156, 1231-1236.

Soper N.J., Strachan R.A., Holdsworth R.E., Gayer R.A. and O'Greiling, R.O. (1992) Sinistral transpression and the Silurian closure of Iapetus. Journal of the Geological Society, London 149, 871-880.

Spear, F.S. (1993) Metamorphic phase equilibria and pressuretemperature-time paths. Mineralogical Society of America.

Spencer, A.M. (1971) Late Precambrian glaciation in Scotland. Memoir of the Geological Society of London, No. 6 . 
Spencer, A.M. (1981) The late Precambrian Port Askaig Tillite in Scotland. In Earth's pre-Pleistocene glacial record (eds. Hambrey, M. J. and Harland, W. B.), pp. 632-636. Cambridge University Press, Cambridge.

Spencer, A.M. (1985) Mechanisms and environments of deposition of Late Precambrian geosynclinal tillites: Scotland and East Greenland. Palaeogeography, Palaeoclimatology and Palaeoecology, $51,143-157$.

Spencer, A.M. and Pitcher, W.S. (1968) Occurrence of the Port Askaig Tillite in north-east scotland. Proceedings of the Geological Society of London, No. 1650, 195-198.

Spencer, A.M. and Spencer, M. (1972) The Late Precambrian/Lower Cambrian Bonnahaven Dolomite of Islay and its stromatolites. Scottish Journal of Geology, 8, 269-282.

Spray J.G. and Dunning G.R. (1991) A U/Pb age for the Shetland Islands oceanic fragment, Scottish Caledonides: evidence from anatectic plagiogranites in "layer 3" shear zones. Geological Magazine 128, 667-671.

Stephenson, D. (1993) Amphiboles from Dalradian metasedimentary rocks of $\mathrm{NE}$ Scotland: environmental inferences and distinction from meta-igneous amphibolites. Mineralogy and Petrology, Vol. $49,45-62$.

Stephenson, D., Bevins, R.E., Millward, D., Highton, A.J., Parsons, I., Stone, P. and Wadsworth, W.J. (1999) Caledonian Igneous rocks of Great Britain. Geological Conservation Review Series No.17. Joint Nature Conservation Committee, Peterborough. 648pp.

Stephenson, D. and Gould, D. (1995) British regional geology: the Grampian Highlands (4 $4^{\text {th }}$ edition). HMSO for the British Geological Survey, London.

Stewart, A.D. (1960) On the sedimentary and metamorphic history of the Torridonian, and the later igneous intrusions of Colonsay and Oronsay. Unpublished PhD thesis, University of Liverpool.

Stewart, A.D. (1962) On the Torridonian sediments of Colonsay and their relationship to the main outcrop in north-west Scotland. Liverpool and Manchester Geological Journal 3, 121-156.

Stewart, A.D. (1969) Torridonian rocks of Scotland reviewed. In Kay, M. (ed.) North Atlantic-Geology and Continental Drift, a symposium. Memoir of the American Association of Petroleum Geologists 12, 595-608.

Stewart, A.D. (1975) 'Torridonian' rocks of western Scotland. In: A correlation of Precambrian rocks in the British Isles (eds. Harris, A. L., Shackleton, R. M., Watson, J.V., Downie, C., Harland, W. B. and Moorbath, S.) Geological Society, London, Special Report, 6, 43-51.

Stewart, A.D. and Hackman, B.D. (1973) Precambrian sediments of Islay. Scottish Journal of Geology, 9, 185-201.

Stewart, M., Strachan, R.A. and Holdsworth, R.E. (1999) Structure and early kinematic history of the Great Glen fault zone, Scotland. Tectonics 18, 326-342.

Stewart, M., Strachan, R.A., Martin, M.W. and Holdsworth, R.E. (2001) Constraints on early sinistral displacements along the Great Glen Fault Zone, Scotland; structural setting, U-Pb geochronology and emplacement of the syn-tectonic clunes Tonalite. Journal of the Geological Society, London 158, 821-830.

Stoker, M.S., Howe, J.A. and Stoker, S.J. (1999) Late Vendian?Cambrian glacially influenced deep-water sedimentation, Macduff 
Slate Formation (Dalradian), NE Scotland. Journal of the Geological Society, London, 156, 55-61.

Stone, M. (1957) The Aberfoyle Anticline, Callander, Perthshire. Geological Magazine, 94, 265-276.

Stone, P., Plant, J.A., Mendum, J.R. and Green, P.M. (1999) A regional geochemical assessment of some terrane relationships in the British Caledonides. Scottish Journal of Geology, 35, 145-156.

Strachan, R.A. (2000) The Grampian Orogeny: Mid-Ordovician arccontinent collision along the Laurentian margin of Iapetus. In: Woodcock, N.H. and Strachan, R.A. (eds) Geological History of Britain and Ireland. Blackwell Science Ltd, 88-106.

Strachan, R.A., Harris, A.L., Fettes D.J. and Smith, M. (2002) The Northern Highland and Grampian terranes. In: Trewin N. H. (ed.) The Geology of Scotland. (4th edition) The Geological Society, London, pp. 81-148.

Strachan, R.A. and Holdsworth, R.E. (2000) Proterozoic sedimentation, orogenesis and magmatism on the Laurentian Craton (2700-750 Ma). In: Geological history of Great Britain and Ireland (edited by Woodcock, N. and Strachan, R. A.) Blackwell Science. Oxford, 52-72.

Stringer, P.J. (1957) Polyphase deformation in the Upper Dalradian rocks of the Southern Highlands of Scotland. Unpublished PhD thesis, University of Liverpool.

Stupavsky, M., Symons, D.T.A. and Gravenor, C.P. (1982) Evidence for metamorphic remagnetisation of the upper Precambrian tillite in the Dalradian Supergroup of Scotland. Transactions of the Royal Society of Edinburgh, 73, 59-65.

Sturt, B.A. (1959) Studies in the metamorphic rocks of the Loch Tummel district, Perthshire. Unpublished PhD thesis, University of Wales, Aberystwyth.

Sturt, B.A. (1961) The geological structure of the area south of Loch Tummel. Quarterly Journal of the Geological society of London, Vol. 117, 131-156.

Sturt, B.A. and Harris, A.L. (1961) The metamorphic history of the Loch Tummel area. Liverpool and Manchester Geological Journal, Vol. 2, 689-711.

Sturt, B.A., Ramsay, D.M., Pringle, I.R. and Teggin, D.E. (1977) Precambrian gneisses in the Dalradian sequence of NE Scotland. Journal of the Geological Society of London, Vol. 134, $41-44$.

Sutton, J. and Watson, J.V. (1954) Ice-borne boulders in the Macduff Group of the Dalradian of Banffshire. Geological Magazine, Vol. 91, 391-398.

Sutton, J. and Watson, J.V. (1955) The deposition of the Upper Dalradian rocks of the Banffshire coast. Proceedings of the Geologists' Association, Vol. 66, 101-133.

Sutton, J. and Watson, J.V. (1956) The Boyndie syncline of the Dalradian of the Banffshire coast. Quarterly Journal of the Geological Society of London, Vol. 112, 103-130.

Tanner, P. W. G. 1992. Rosneath Peninsula and Loch Long. In Geological excursions around Glasgow and Girvan (eds. Lawson, $J$. D. and Weedon, D. S.), pp. 159-185. Geological Society of Glasgow.

Tanner, P. W. G. 1995. New evidence that the Lower Cambrian Leny Limestone at Callander, Perthshire, belongs to the Dalradian supergroup, and a reassessment of the 'exotic' status of the Highland Border Complex. Geological Magazine, 132, 473-483. 
Tanner, P. W. G. 1996. Significance of the early fabric in the contact metamorphic aureole of the 590 Ma Ben Vuirich Granite, Perthshire, Scotland. Geological Magazine, 133, 683-695.

Tanner, P. W. G. 1997. The Highland Border controversy: Reply to a Discussion of 'New evidence that the Lower Cambrian Leny Limestone at Callander, Perthshire, belongs to the Dalradian Supergroup, and a reassessment of the 'exotic' status of the Highland Border Complex'. Geological Magazine, 134, 565-570.

Tanner, P. W. G. 1998a. Interstratal dewatering origin for polygonal patterns of sand-filled cracks: a case study from Late Proterozoic metasediments of Islay, Scotland. Sedimentology, 45, $71-89$.

Tanner, P W G. 1998b. Age of the Grampian event: Reply to a Discussion of 'New evidence that the Lower Cambrian Leny Limestone at Callander, Perthshire belongs to the Dalradian Supergroup, and a reassessment of the 'exotic' status of the Highland Border Complex'. Geological Magazine, Vol. 135, 575-579.

Tanner, P. W. G. 2005. Discussion on evidence for a major Neoproterozoic orogenic unconformity within the Dalradian Supergroup of NW Ireland. Journal of the Geological Society, London, 162, 221-224.

Tanner, P.W.G. 2007. The role of the Highland Border Ophiolite in the 470 Ma Grampian Event, Scotland. Geological Magazine Vol. $144,597-602$.

Tanner, P.W.G. 2008. Tectonic significance of the Highland Boundary Fault. Journal of the Geological Society, London Vol. 165, 915921.

Tanner, P.W.G. and Bluck, B.J. (2011) Discussion of 'The Highland Boundary Fault and the Highland Boundary Complex' by B.J. Bluck Scottish Journal of Geology 46, 113-124. Scottish Journal of Geolgy, 47, 89-93.

Tanner, P. W. G. and BLUCK, B. J. 1999. Current controversies in the Caledonides. Journal of the Geological Society, London, 156, 1137-1141.

Tanner, P. W. G. and Evans, J. A. 2003. Late Precambrian U-Pb titanite age for peak regional metamorphism and deformation (Knoydartian Orogeny) in the western Moine, Scotland. Journal of the Geological Society, London 160, 555-564.

Tanner, P. W. G. and Leslie, A. G. 1994. A pre-D2 age for the 590 Ma Ben Vuirich Granite in the Dalradian of Scotland. Journal of the Geological Society, London, 151, 209-212.

Tanner P. W. G., Leslie A. G. and Gillespie M.R. 2006. Structural setting and petrogenesis of a rift-related intrusion: the Ben Vuirich Granite of the Grampian Highlands, Scotland. Scottish Journal of Geology, Vol. 42, 113-136.

Tanner, P. W. G. and Pringle, M. 1999. Testing for a terrane boundary within Neoproterozoic (Dalradian) to Cambrian siliceous turbidites at Callander, Perthshire, Scotland. Journal of the Geological Society, London, 156, 1205-1216.

Tanner, P.W.G. and Sutherland, S. 2007. The Highland Border Complex, Scotland: a paradox resolved. Journal of the Geological Society, London, 164, 111-116.

Tannner, P.W.G. and Thomas, P.R. (2010) Major nappe-like D2 folds in the Dalradian rocks of the Beinn Udlaidh area, Central Highlands, Scotland. Earth and Environmental Science Transactions of the Royal Society of Edinburgh. 100, 371-389. 
Temperley, S. (1990). The Late Proterozoic to Early Palaeozoic geology of the Glen Banchor area in the Monadhliath Mountains of Scotland, with particular reference to deformation in Knoydartian shear zones and the Caledonian Central Highland steep belt. Unpublished PhD thesis, University of Hull.

Thomas, C W. 1989. Application of geochemistry to the stratigraphic correlation of Appin and Argyll Group carbonate rocks from the Dalradian of northeast Scotland. Journal of the Geological Society of London, Vol. 146, 631-647.

Thomas, C. W. 1993. Sources of Rare Earth elements in Appin Group limestones, Dalradian, north-east Scotland. Mineralogy and Petrology Vol. 49, 27-44.

Thomas, C.W. (1995). The geochemistry of metacarbonate rocks from the Monadhliath Project area. British Geological Survey Technical Report. WA/95/40/R.

Thomas, C. W. (1999). The isotope Geochemistry and Petrology of Dalradian Metacarbonate Rocks, Unpublished PhD thesis, University of Edinburgh.

Thomas, C.W. and Aitchison (1998). Application of logratios to the statistical analysis of the geochemistry of metamorphosed limestones from the Northeast and Central Highlands of Scotland: the case for Appin Group correlations. British Geological Survey Technical Report, WA/98/03.

Thomas, C W, Aitken, A M, Pickett, E P, Mendum, J R, Hyslop, E K, and Petterson, M.P. in press. Geology of the Aberfoyle District. Sheet Description for the British Geological Survey, 1:50 000 Series Sheet 38E (Scotland).

Thomas, C. W., Graham, C. M., Ellam, R.M. and Fallick, A. E. (2004). ${ }^{87} \mathrm{Sr} /{ }^{8} 6 \mathrm{Sr}$ chemostratigraphy of Neoproterozoic Dalradian limestones of Scotland: constraints on depositional ages and timescales. Journal of the Geological Society, London 161, 223243.

Thomas, C.W., Smith, M. and Robertson, S. (1997). The geochemistry of Dalradian metacarbonate rocks from the Schiehallion District and Blargie, Laggan: implications for stratigraphical correlations in the Geal Charn-Ossian Steep Belt. British Geological Survey Technical Report, WA/97/81.

Thomas, P R. 1965. The structure and metamorphism of the Moinian rocks in Glen Garry, Glen Tilt, and adjacent areas of Scotland. Unpublished PhD thesis, University of Liverpool.

Thomas, P R. 1979. New evidence for a Central Highland Root Zone. 205-211 in The Caledonides of the British Isles -Reviewed. Harris, A L, Holland, C H, and Leake, B E (editors). Special Publication of the Geological Society, No. 8.

Thomas, P R. 1980. The stratigraphy and structure of the Moine rocks north of the Schiehallion Complex, Scotland. Journal of the Geological Society of London, Vol. 137, 469-482.

Thomas, P R. 1988. A9 road section-Blair Atholl to Newtonmore. $39-50$ in An excursion guide to the Moine geology of the Scottish Highlands. Allison, I, May, F, and Strachan, R A (editors). (Edinburgh: Scottish Academic Press for Edinburgh Geological Society and Geological Society of Glasgow.)

Thomas, P R, and Treagus, J E. 1968. The stratigraphy and structure of the Glen Orchy area, Argyllshire, Scotland. Scottish Journal of Geology, Vol. 4, 121-134.

Thomson, J. 1877. On the geology of the Island of Islay. Transactions of the Geological Society of Glasgow, 5, 200-222. 
Tilley, C.E. (1925) A preliminary survey of metamorphic zones in the southern Highlands of Scotland. Quarterly Journal of the Geological Society of London, Vol. 81, 100-110.

Tollo R. P., Aleinikoff J. N., Bartholomew M. J. and Rankin D. W. 2004. Neoproterozoic A-type granitoids of the central and southern Appalachians: intraplate magmatism associated with episodic rifting of the Rodinian supercontinent. Precambrian Research, 128, 3-38.

Torsvik, T. H., Smethurst, M. A., Meert, J. G., Van der Voo, R., McKerrow, W. S., Brasier, M. D., Sturt, B. A. and Walderhaug, H. J. 1996. Continental break-up and collision in the Neoproterozoic and Palaeozoic-a tale of Baltica and Laurentia. Earth Science Reviews 40, 229-258.

Treagus, J. E. 1964a. The structural and metamorphic history of an area of Moine and Dalradian rocks south of Loch Rannoch, Perthshire. Unpublished PhD thesis, University of Liverpool.

Treagus, J E. 1964b. Notes on the structure of the Ben Lawers Synform. Geological Magazine, Vol. 101, 260-270.

Treagus, J.E. (1969). The Kinlochlaggan Boulder Bed. Proceedings of the Geological Society of London, 1654, 55-60.

Treagus, J E. 1974. A structural cross-section of the Moine and Dalradian rocks of the Kinlochleven area, Scotland. Journal of the Geological Society of London, Vol. 130, 525-544.

Treagus, J.E. (1981). The Lower Dalradian Kinlochlaggan Boulder Bed, Central Scotland. In: Earth's pre-Pleistocene glacial record. (editors. Hambrey, J.M. and Harland, W.B.), Cambridge University Press, 637-639.

Treagus, J E. 1987. The structural evolution of the Dalradian of the Central Highlands of Scotland. Transactions of the Royal Society of Edinburgh: Earth Sciences, Vol. 78, 1-15.

Treagus, J E. 1991. Fault displacements in the Dalradian of the Central Highlands. Scottish Journal of Geology, Vol. 27, 135-145.

Treagus, J. E. (editor). 1992. Caledonian Structures in Britain South of the Midland Valley, Geological Conservation Review Series No. 3. London: Chapman and Hall.

Treagus, J.E. (1997) Discussion on a late Vendian age for the Kinlochlaggan Boulder bed (Dalradian). Journal of the Geological Society, London, 154, 917-919.

Treagus, J E. 1999. A structural reinterpretation of the Tummel Belt and a transpressional model of evolution of the Tay Nappe in the Central Highlands of Scotland. Geological Magazine, Vol. 136, Pt 6, 643-660.

Treagus, J. E. 2000. The Solid Geology of the Schiehallion District. Memoir of the British Geological Survey. Sheet 55W (Scotland).

Treagus, J.E. 2009. The Dalradian of Scotland. Geologists' Association Guide No. 67. 202pp.

Treagus, J E, and King, G. 1978. A complete Lower Dalradian succession in the Schiehallion district, central Perthshire. Scottish Journal of Geology, Vol. 14, 157-166.

Treagus, J E, Pattrick, R A D, and Curtis, S F. 1999. Movement and mineralization in the Tyndrum fault zone, Scotland and its regional significance. Journal of the Geological Society, London, Vol. 156, 591-604.

Treagus, J E. and Roberts, J L. 1981. The Boyndie Syncline, a D1 structure in the Dalradian of Scotland. Geological Journal, Vol. $16,125-135$. 
Treagus, J E, Talbot, C J, and Stringer, P. 1972. Downward-facing structures in the Birnam Slates, Dunkeld, Perthshire. Geological Journal, Vol. 8, 125-128.

Treagus, J E, and Treagus, S H. 1971. The structures of the Ardsheal peninsula, their age and regional significance. Geological Journal, Vol. 7, 335-346.

Treagus, J E, and Treagus, S H. 1981. Folds and the strain ellipsoid; a general model. Journal of Structural Geology, Vol. 3, Pt $1,1-17$.

Trewin, N. H. (editor) 2002. The Geology of Scotland. (4th edition) The Geological Society, London. $576 \mathrm{pp}$.

Trewin, N.H., Kneller, B.C. and Gillen, C. (1987) Excursion Guide to the Geology of the Aberdeen area. (Edinburgh: Scottish Academic Press, for Geological Society of Aberdeen).

Trewin, N.H. and Rollin, K. 2002. In: Trewin, N.H. (ed.) The geology of Scotland.(4th edition) The Geological Society, London, $1-25$.

Trewin, N.H. and Thirlwall, M.F. 2002. Old Red Sandstone. In: Trewin N. H. (ed.) The Geology of Scotland. ( $4^{\text {th }}$ edition) The Geological Society, London, pp. 213-249.

Tyrrell, G.W. 1921. Some points in petrographic nomenclature. Geological Magazine Vol. 58, 494-502.

Underhill, J.R. 1993. Discussion on the location and history of the Walls Boundary fault and Moine thrust north and south of Shetland. Journal of the Geological Society, London, 150, 1003-1008.

Upton, P.S., 1983. A stratigraphic, structural and metamorphic study of the lower and middle Dalradian, between Braemar and the Spittal of Glenshee, N.E. Scotland. Unpublished PhD thesis, University of Manchester.

Upton, P S. 1986. A structural cross-section of the Moine and Dalradian rocks of the Braemar area. Report of the British Geological Survey, Vol. 17, No. 1, 9-19.

Van Breemen, O., Aftalion, M. and Johnson, M. R. 1979. Age of the Loch Borrolan complex, Assynt and late movements along the Moine Thrust Zone. Journal of the Geological Society of London 16, 489495 .

Van de Kamp, P.C. 1968. Origins of para-amphibolites. Unpublished PhD thesis, University of Bristol.

Van de Kamp, P C. 1970. The Green Beds of the Scottish Dalradian Series: geochemistry, origin and metamorphism of mafic sediments. Journal of Geology, Vol. 78, 281-303.

Van Staal, C. R., Dewey, J. F., McKerrow, W. S. and MacNiocaill, C. 1998. The Cambrian-Silurian tectonic evolution of the northern Appalachians and British Caledonides: history of a complex, southwest Pacific-type segment of Iapetus. In: Lyell: the Present is in the Past (edited by Blundell, D. J. and Scott, A. C.). Geological Society, London, Special Publication, 143, 199-242.

Vance, D., Strachan, R. A. and Jones, K. A. 1998. Extensional versus compressional settings for metamorphism: Garnet chronometry and pressure-temperature-time histories in the Moine Supergroup, northwest Scotland. Geology 26, 927-930.

Viete, D.R., Forster, M.A. and Lister, G.S. (2011) The nature and origin of the Barrovian metamorphism, Scotland: ${ }^{40} \mathrm{Ar} /{ }^{39} \mathrm{Ar}$ apparent age patterns and the duration of metamorphism in the biotite zone. Journal of the Geological Society, London, 168, 133-146. 
Viete, D.R., Hermann, J., Lister, G.S. and Stenhouse, I.R. (2011) The nature and origin of the Barrovian metamorphism, Scotland: diffusion length scales in garnet and inferred thermal time scales. Journal of the Geological Society, London, 168, 115-132.

Viete, D.R., Richards, S.W., Lister, G.S., Oliver, G.J.H. and Banks, G.J. (2010) Lithospheric-scale extension during Grampian orogenesis in Scotland. in Law, R.D., Butler, R.W.H., Holdsworth, R.E., Krabbendam, M. and Strachan, R.A. (editors) Continental Tectonics and Mountain Building: the Legacy of Peach and Horne. Geological Society, London, Special Publications, 335, 121-160.

Viljoen, M. J and Viljoen, R. P. 1969. Evidence for the existence of a mobile extrusive peridotite magma from the Komati Formation of the Onverwacht Group. Geological Society of South Africa, Special Publication No. 2, 87-112.

Vogt, T. 1930. On the chronological order of deposition in the Highlands. Geological Magazine, 67, 68-76.

Voll, G. 1960. New work on Petrofabrics. Liverpool and Manchester Geological Journal, 2, 503-567.

Voll, G. 1964. Deckenbau und fazies im Schottischen Dalradian. Geologische Rundschau, Vol. 53, 590-612.

Vorhies, S.H. and Ague, J.J. (2011) Pressure - temperature evolution and thermal regimes in the Barrovian zones, Scotland. Journal of the Geological Society, London, 168, 1147-1166.

Wain, A. (1999). The petrography and metamorphic evolution of metabasic rocks from the Lower Dalradian of the Central Highlands area. British Geological Survey Technical Report No. WA/99/13.

Watkins, K.P. 1982. The structure and metamorphism of the Balquhidder-Crianlarich region of the Scottish Dalradian. Unpublished PhD thesis, University of Cambridge.

Watkins, K P. 1983. Petrogenesis of Dalradian albite porphyroblast schists. Journal of the Geological Society of London, Vol. 140, $601-618$.

Watkins, K P. 1984. The structure of the Balquhidder-Crianlarich region of the Scottish Dalradian and its relation to the Barrovian garnet isograd surface. Scottish Journal of Geology, Vol. 20, 5364 .

Watkins, K.P. 1985. Geothermometry and geobarometry of inverted metamorphic zones in the $W$. Central Scottish Dalradian. Journal of the Geological Society of London, 142, 157-165.

Watson, J. V. 1984. The ending of the Caledonian Orogeny in Scotland. Journal of the Geological Society of London 141, 193214 .

Weiss, L E, and McIntyre, D B. 1957. Structural geometry of Dalradian rocks at Loch Leven, Scottish Highlands. Journal of Geology, Vol. 65, 575-602.

Wells, P. R. A. and Richardson, S. W. 1979. Thermal evolution of metamorphic rocks in the Central Highlands of Scotland. In Harris, A. L., Holland, C. H. and Leake, B. E. (editors), The Caledonides of the British Isles-reviewed. Geological Society of London Special Publication No. 8, published by Scottish Academic Press, Edinburgh, 339-344.

Whalen J. B., Currie J. L. and Chappell B. W. 1987 . A-type granites: geochemical characteristics, discrimination and petrogenesis. Contributions to Mineralogy and Petrology, 95, 407419. 
Whitten, E H T. 1959. A study of two directions of folding; the structural geology of the Monadhliath and mid-Strathspey. Journal of Geology, Vol. 67, 14-47.

Whittles, K.H. 1981. The geology and geochemistry of the area west of Loch Killin, Inverness-shire. Unpublished PhD thesis, University of Keele.

Wilkinson, S. B. 1907. The geology of Islay. Memoirs of the Geological Survey of Scotland, Sheets 19 and 27, and parts of 20.

Willan, R. C. R., and Coleman, M L. 1983. Sulphur isotope study of the Aberfeldy barite, zinc, lead deposit and minor sulfide mineralization in the Dalradian metamorphic terrain, Scotland. Economic Geology, Vol. 78, 1619-1656.

Williamson, D. H., 1953. Petrology of chloritoid and staurolite rocks north of Stonehaven, Kincardineshire. Geological Magazine, $90,353-361$.

Williamson, $W$ O. 1935. The composite gneiss and contaminated granodiorite of Glen Shee, Perthshire. Quarterly Journal of the Geological Society of London, Vol. 91, 382-422.

Wilson, J.R. and Leake, B.E. 1972. The petrochemistry of the epidiorites of the Tayvalich Peninsula, North Knapdale, Argyllshire. Scottish Journal of Geology 8, 215-252.

Winchester, J.A. 1974. The zonal pattern of regional metamorphism in the Scottish Caledonides. Journal of the Geological society of London, 130 , 509-24.

Winchester, J.A. and Glover, B.W. (1988). The Grampian Group, Scotland. In: Later Proterozoic stratigraphy of the Northern Atlantic region. (editor Winchester, J.A.). Blackie, Glasgow and London, 146-161.

Winchester, J.A. and Glover, B.W. (1991). Grampian Group: PitlochryLoch Laggan-Glen Spean. In: The Late Precambrian Geology of the Scottish Highlands and Islands. (editors Hambrey, M.J., Fairchild, I.J., Glover, B.W., Stewart, A.D., Treagus, J.E. and Winchester, J.A.). Geologists' Association Guide No. 44, 66-85.

Wiseman, J D H. 1934. The central and south-west Highland epidiorites: a study in progressive metamorphism. Quarterly Journal of the Geological Society of London, Vol. 90, 354-417.

Wood, D.S. 1964. Some structures in the Dalradian pillow lavas of the Tayvallich Peninsula, Argyll. Geological Magazine, 101, 481

Woodcock, N. and Strachan, R. 2000. Geological History of Britain and Ireland. Blackwell Science, Oxford.

Wright, A.E. 1976. Alternating subduction direction and the evolution of the Atlantic Caledonides Nature, London 264, 156.

Wright, A. E. 1988. 15. The Appin Group. In Later Proterozoic Stratigraphy of the Northern Atlantic Regions (editor Winchester, J. A.), pp. 177-199. Blackie.

Yardley B. W. D. (1989) An introduction to metamorphic petrology. Longman, Harlow.

Yardley, B.W.D. and Valley, J.W. 1997. The petrologic case for a dry lower crust. Journal of Geophysical Research, 106 B6, 1217312185 .

Zeh, A. and Millar, I. L. 2001. Metamorphic evolution of garnetepidote-biotite gneiss from the Moine Supergroup, Scotland, and geotectonic implications. Journal of Petrology 42, 529-554.

Zenk, M. and Schulz, B. 2004. Zoned Ca-amphiboles and related P-T evolution in metabasites from the classical Barrovian metamorphic 
zones in Scotland. Mineralogical Magazine, 68, 769-786.

Figure 1 Map of the Highland Border region showing the main stratigraphical divisions, axial plane traces of major folds, and locations of the GCR sites. Only areas described in this regional paper are ornamented; outcrop width of the Tayvallich subgroup is exaggerated in places. NB south-west of the Loch Tay Fault, the pelitic rocks shown in the core of the Aberfoyle Anticline are mostly assigned to the Aberfoyle Slate Formation, which is assumed to be relatively low in the Southern Highland Group; north-east of the Loch Tay Fault, the pelitic rocks are at lower structural levels and hence are in higher parts of the succession, such as the Birnam Slate and Grit Formation (see Figure 2). Based on BGS 1:250 000-scale maps and modified by P.W.G. Tanner in the light of recent work.

Lines of section $A A^{\prime}-G^{\prime}$ ' refer to Figure 4.

Axial plane traces of folds: AA Aberfoyle Anticline (F1-F2), BLA Ben Ledi Antiform (F1-F2), BVS Ben Vane Synform (F1-F2), CA Cowal Antiform (F4), HBD Highland Border Downbend (F4).

Faults: BBF Bridge of Balgie Fault, HBF Highland Boundary Fault, LTF Loch Tay Fault, TF Tyndrum Fault.

GCR sites: 1 Ardscalpsie Point, 2 Cove Bay to Kilcreggan, 3 Portincaple, 4 Bealach nam Bo, 5 Duke's Pass, 6 Keltie Water, Callander, 7 Little Glen Shee, 8 Craig a' Barns, 9 Rotmell, 10 Glen Esk, 11 Garron Point to Muchalls.

Figure 2 Stratigraphical columns (not to scale) showing variations in Southern Highland Group stratigraphy along the length of the Highland Border region and variations across the strike, where present. N.B. in the Cowal to Loch Lomond area, equivalent formations on the inverted north-west limb and the right-way-up south-east limb of the Aberfoyle Anticline have different names and are shown separately. Although these do reflect some facies variations, the reason is largely historical, dating back to the period before the anticline was recognized. Capital letters in column headings refer to cross-sections in Figure 4. GCR sites are numbered as on Figure 1.

Figure 3 'Gneiss Rock at Glenfinlas', 1853-54 (pen, wash and gouache on paper), John Ruskin (1819-1900) (C) Ashmolean Museum, University of oxford. This picture took several months to complete and lovingly and precisely depicts the tortuous shapes wrought by weathering of the strongly developed S1/S2 cleavage typical of Southern Highland Group rocks south-east of the Highland Border Downbend. The site is in the River Turk, by Brig O'Turk (Greive, 1996), a few hundred metres north of the northern boundary of Figure 18 .

Figure 4 True-scale serial sketch cross-sections across the Tay Nappe and Highland Border Downbend, as viewed to the south-west in the plunge direction of the downbend. Limits of cross-sections and lines of section as shown on Figure 1 are notional and do not reflect current level of erosion.

$A A^{\prime}$ Isle of Bute to Loch Fyne.

BB' West side of Loch Lomond. 
CC'Aberfoyle to Loch Katrine. (after Section 1, BGS 1:50 000

Sheet 38E, Aberfoyle, 2005).

DD' Callander. (unpublished cross-section by J.R. Mendum) .

EE' Dunkeld. (after Figure 24a).

FF' Glen Shee. (after sections 1, 2 and 4, BGS 1:50 000 sheet

56W, Glen Shee, 1999).

GG'Stonehaven. (after Figure 33).

Positions of GCR sites, projected onto the nearest equivalent cross-section, are numbered as on Figure 1.

Figure 5 A composite figure prepared from C.T. Clough's field sketches, as reproduced in the Geological Survey's Cowal memoir (Clough, in Gunn et al., 1897, figs 12 and 13). The individual sketches are arranged diagrammatically with respect to their inferred position on the Cowal Antiform. It is clear from these sketches that Clough understood how to identify and unravel the effects of polyphase deformation some sixty years before John Ramsay demonstrated it at Glenelg (Ramsay, 1958).

Figure 6 Map showing the bedding-cleavage relationships in the Dalradian rocks immediately north-west of a splay of the Highland Boundary Fault, north of Ardscalpsie Point, Isle of Bute. A-F, reference points on the line of cross-section shown in Figure 8.

\section{Figure 7}

(a) An inland exposure at Ardscalpsie Point (NS 0440 5766), showing the bedding-cleavage relationship found typically on the upper limb of the Tay Nappe at this GCR site. Bedding, which is parallel to the hammer shaft, is cut by the spaced sl cleavage (seen as etched lines on the surface) that dips at a more-gentle angle to the south-east (right on photo). Hammer shaft is $60 \mathrm{~cm}$ long. (Photo: P.W.G. Tanner.)

(b) Photomicrograph showing the relatively undeformed nature of the D1 metasandstone microlithons which, together with the intervening thin dark cleavage domains, constitute the Sl cleavage in (a).

(Photos: P.W.G. Tanner.)

Figure 8 A true-scale, NNW-SSE-trending cross-section, prepared from field sketches, of the structures along the line $A-F$ in Figure 6, Ardscalpsie Point GCR site.

Figure 9 Map of the southern end of the Rosneath peninsula, including the Cove Bay to Kilcreggan GCR site, based on BGS 1:50 000 Sheet 30W (Greenock, 1990).

\section{Figure 10}

(a) Centimetre-wide microlithons, separated by narrow dark anastomosing cleavage domains which, together form the main, SEdipping, s2 fabric in the metagreywacke unit of the Dunoon Phyllite Formation near Barons Point (NS 223 808). The spaced S1 fabric can be clearly seen locally within the microlithons, frozen in the act of transformation to S2. The L2 intersection lineation occurs as a ribbon lineation on the main fabric surface. 
(b) Photomicrograph of the D2 microlithons in (a), reworking S1 pressure-solution stripes (shown in their original state in Figure $7 \mathrm{~b})$.

(Photos: P.W.G. Tanner.)

\section{Figure 11}

(a) Location map of the Portincaple GCR site. Bedrock is the Beinn Bheula Schist Formation, cut by the few dykes shown. A-B, CD, lines of cross-section for (b) .

(b) True-scale field sketch of a vertical cross-section, viewed approximately down-plunge for F4, across the southern part of the hinge-zone of the Highland Border Downbend (F4). The main fabric in these rocks is a centimetre-spaced pressure-solution (or dissolution) cleavage (S2).

(c) Equal-area stereographic projection showing poles to the S2 fabric that defines a best-fit great circle whose $\pi$ axis plunges at $10^{\circ}$ to $079^{\circ}$, parallel to the major $\mathrm{F} 4$ fold axis of the Highland Border Downbend.

\section{Figure 12}

(a) A vertical rock face in the Bheinn Bheula Schist Formation at Portincaple (NS 2297 9327), viewed to the north-east $\left(054^{\circ}\right.$ ), showing asymmetrical, Z-shaped $F 3$ folds on the southern limb of the Highland Border Downbend. The D3 structures deform the main S2 spaced fabric; the poorly developed minor upright F4 folds are accompanied by a near-vertical, crenulation cleavage that, although restricted to the pelitic seams, is clearly imprinted on and hence post-dates all of the other structures. Note the local preservation of the S1 fabric within the S2 microlithons. (Photo: P.W.G. Tanner.)

(b) An explanatory outline drawing of (a).

(c) Photomicrograph of the $\mathrm{S} 4$ crenulation cleavage at $\mathrm{X}$ on (b). (Photo: P.W.G. Tanner.)

Figure 13 Cross-section from Callander due north to Loch Tay. The section continues the Flat Belt from the southern end of the section in Figure $3.3 \mathrm{~b}$ and shows the position of the Keltie Water (KW), Bealach nam Bo (BB) and Dukes Pass (DP) GCR sites within the Steep Belt created by the F4 Highland Border Downbend. The assumption is made that there is a single continuous unit of 'green beds'.

Figure 14 Map of the area around Bealach nam Bo, Loch Katrine, Trossachs. Based upon mapping by the British Geological Survey, 1996-1998.

Figure 15 Sedimentological log through 'green beds' in the Loch Katrine Volcaniclastic Formation, exposed in cliffs at Bealch nam Bo. Adapted from Burt (2002).

Figure 16 Fl folds with axial planar cleavage picked out by quartz veins in 'green beds' and cleaner metasandstone in the Loch Katrine Volcaniclastic Formation at Bealach nam Bo (NN 478 075). Lens cap is $50 \mathrm{~mm}$ diameter. (Photo: C.W. Thomas, BGS No. P 726593.) 
Figure 17 F2 crenulation folds of the first cleavage in the Creag Innich Sandstone Formation at NN 4777 0714, Bealach nam Bo GCR site. Lens cap is $50 \mathrm{~mm}$ diameter. (Photo: C.W. Thomas, BGS No. P 726594.)

Figure 18 Map of the area around the Duke's Pass, Aberfoyle. Based upon mapping by the British Geological Survey, 1996-1998.

Figure 19 Typical F1 fold in metasandstone of the Creag Innich Sandstone Formation at NN 51440344 on the Duke's Pass, Aberfoyle. The coarse-grained base of a gritty metasandstone unit lies above the hammer head, passing down into finer grained rock towards the end of the handle. The rocks are inverted and the fold is downward facing. Hammer shaft is $36 \mathrm{~cm}$ long. (Photo: C.W. Thomas. BGS No. P 643897.)

Figure 20 Map of the Keltie Water, Callander GCR site. Locations of photomicrographs (Figure 21, a-e) and the field photograph (Figure 22) are indicated. The position of the putative terrane boundary between the Grampian Terrane and the Highland Border 'exotic terrane' (Brasier et al., 1992) is also shown for reference.

The inset map shows three structural sub-areas sited across the boundary between undoubted Dalradian rocks of the Ben Ledi Grit Formation (A), and the lower part of the Keltie Water Grit Formation, including the Transition Member (B). Sub-area C consists mainly of gritty metasandstones of the Keltie Water Grit Formation, comparable in lithology to the rocks in sub-area A. Equal-area stereographic projections for each of these sub-areas show the poles to the main cleavage, together with their computed mean orientation shown as a great circle (solid line).

Figure 21 Photomicrographs of medium- to coarse-grained metagreywackes from the Keltie water section, and a related exposure $5 \mathrm{~km}$ to the south-west. The photomicrographs illustrate the similarities in petrography and strain state of samples from (a) the Ben Ledi Grit Formation, (b) the Transition Member, (c) the lower part of the Keltie Water Grit Formation, above the Transition Member, (d) the Keltie Water Grit Formation above the Keltie Limestone and Slate Member and (e) the upper part of the Keltie Water Grit Formation above the Leny Limestone and Slate Member. The selected photomicrographs are representative examples chosen from over 100 thin sections and full details of the petrography were given by Tanner and Pringle (1999). Locations of samples are shown on Figure 20, except for (e) which is located at NN 6037 0858. All photomicrographs are at the same scale with a width equivalent to approximately $4 \mathrm{~mm}$. (Photos: P.W.G. Tanner.)

Figure 22 Spaced S1 cleavage, with microlithons $1-3 \mathrm{~cm}$ thick, associated with a minor fold in gritty metasandstones of the Keltie Water Grit Formation. Section viewed to the north-east. This exposure (see Figure 20 for location) was removed totally by a recent flood. (Photo: P.W.G. Tanner.) 
Figure 23 Map of the Dunkeld - Pitlochry area to show the main lithostratigraphical units, the main elements of the structure and the locations of the Little Glen Shee, Craig a'Barns and Rotmell GCR sites. Adapted from Rose and Harris (2000, figure 2).

\section{Figure 24}

(a) Schematic cross-section from Pitlochry to Dunkeld to show the location of Figure 24b, and the position of the Little Glen shee, Craig a'Barns and Rotmell GCR sites in relation to the Tay Nappe.

(b) Schematic cross-section across the Flat Belt (FB), the Highland Border Downbend (HBD), the Highland Border Steep Belt (HBSB) and the Highland Boundary Fault (HBF) to show the position of the Little Glen Shee, Craig a'Barns and Rotmell GCR sites in relation to the detailed geology of the district. Adapted from a drawing by P.T.S. Rose.

Figure 25 Geological relationships at the crag that comprises the Little Glen Shee GCR site, to show the geometry of the folds and the general direction of younging of the beds. Insets 1 and 2 show the detail of relations between bedding and the refracted cleavage on alternate fold limbs. Locations of photographs, Figures $26 \mathrm{a}$ and 26b, are shown. Adapted from a field sketch by P.W.G. Tanner with insets from P.T.S. Rose.

Figure 26 Detailed sedimentological and structural features of the Little Glen Shee GCR site at locations shown in Figure 25.

(a) Cleavage types and refraction related to rock type. A spaced cleavage (S1P) occurs in metasandstones in the centre of the photo and is refracted as it passes into a slaty cleavage (S1) in metasiltstones on either side. To the right there is a sharp lithological change at the base of the metasandstone unit, but to the left the more gradual refraction brings out grading from one lithology into another. Younging is to the left (north-northwest). Coin is $1.2 \mathrm{~cm}$ in diameter.

(b) Detail of the minor fold-pair diagrammatically represented in Figure 25 and discussed in the text. Coin is $1.2 \mathrm{~cm}$ in diameter.

(Photos: A.L. Harris.)

Figure 27 Location map of the Craig a'Barns GCR site, showing the position of localities $A-D$ described in the text and the approximate trace of the Highland Border Downbend (HBD) .

Figure 28 Detailed structural relationships at the Craig a'Barns GCR site.

(a) Sketch taken from a photograph of the fold at locality $B$ on Figure 27, discussed in the text. A metasandstone bed contains tight $\mathrm{F} 2$ folds of S1p showing consistent vergence on opposite limbs of the Highland Border Downbend-related, step-like open fold.

(b) The association between the Highland Border Downbend-related crenulation cleavage (overdrawn straight lines, labelled S4) and folded bedding (SO), seen at or near the core of the downbend at locality $C$ on Figure 27. At the top of the photograph, bedding is essentially parallel to both $\mathrm{S} 1$ and $\mathrm{S} 2$ but in the bottom left, S1p is at a distinct angle to bedding. Looking north-east, width of exposure about $60 \mathrm{~cm}$. (Photo: A.L. Harris.) 
(c) Detail of the crenulation cleavage related to the Highland Border Downbend at locality $C$ on Figure 27. Looking north-east, width of exposure $20 \mathrm{~cm}$. (Photo: A.L. Harris.)

Figure 29 Intense $\mathrm{F} 2$ folds of the S1p cleavage at the Rotmell GCR site. Note the contrast in thickness between Slp microlithons in the hinges of the $F 2$ folds and those on the limbs. Top-to-theright (south-east) shear is inferred. Looking north-east at NO 0128 4118. Field of view is approximately $50 \mathrm{~cm}$ high. (Photo: J.E. Treagus.)

Figure 30 Map of lower Glen Esk showing the full range of regional metamorphic zones first erected by Barrow (1893, 1912). Redrawn from Harte (1987), with modifications based on BGS 1:50 000 Sheet 66W (Aboyne, 1995).

Figure 31 Photomicrographs (a-d, f) and one field photo (e) illustrating the sequence of Barrow's Zones, as represented in the Glen Esk GCR site. Rocks photographed come from the localities described in the text, except for the sillimanite zone (f), which is from a locality by Glen Effock (described by Harte, 1987). All photomicrographs are at the same scale with a width equivalent to approximately $4.5 \mathrm{~mm}$. (Photos: B. Harte.)

(a) Chlorite zone. Principal minerals are quartz, white mica, chlorite and opaques (iron oxide and sulphide). The bedding and main cleavage are approximately parallel to the top edge of photo, and the upper (darker) half of the photo represents a chlorite-rich layer, whilst the lower part is more quartz rich. A later cleavage is visible as pale (white mica-rich) seams cutting obliquely across the chlorite-rich layer.

(b) Biotite Zone. Biotite porphyroblasts (Bt) overgrow a finer grained matrix of quartz, white mica, chlorite and opaque iron minerals. The bedding and main cleavage are roughly parallel to the top edge of the photo.

(c) Garnet zone. Biotite (Bt) and garnet (Grt) porphyroblasts in a finer grained matrix of quartz, white mica, chlorite and opaque iron minerals. Areas in the matrix richer in chlorite (Chl) have a darker appearance.

(d) Staurolite zone. Porphyroblasts of garnet (Grt and highest relief), staurolite(St and high relief) and biotite (Bt and moderate relief) in a matrix of quartz and muscovite with a small amount of opaque iron minerals.

(e) Kyanite zone. Field photo of a vein dominantly of quartz and kyanite; the label is in the centre of a rosette of kyanites. Penknife is $10 \mathrm{~cm}$ long.

(f) Sillimanite Zone. A large $(2 \mathrm{~mm})$ porphyroblast of garnet (Grt) in the centre, together with smaller porphyroblasts of kyanite (KY) and staurolite (St). The 'Sill' label is on a cluster of sillimanite fibres (fibrolite). Darker areas to the left and right of the garnet are of biotite intergrown with fibrolite. Pale areas are dominated by muscovite and quartz.

Figure 32 Location of the coast section in Southern Highland Group rocks from Garron Point to Muchalls, north of Stonehaven, showing the principal structural and metamorphic features. After BGS 1:50 000 Sheet 67 (Stonehaven, 1999), with approximate 
locations of metamorphic mineral isograds based on Harte et al. (1987, figure 2a).

Figure 33 Partly schematic structural cross-section of the coast north of Garron Point, Stonehaven, showing the contrast in dip of bedding in the Flat and steep belts, the principle F1 and F4 folds and the limits of D2 and D4 deformation in metasandstones. Structures observed on the coast have been projected onto the line A-A' shown on Figure 27. Section is true scale (no vertical exaggeration). After BGS 1:50 000 Sheet 67 (Stonehaven, 1999).

Figure 34 Cleavage/bedding relationships in Southern Highland Group rocks of the Garron Point to Muchalls GCR site.

(a) Widely spaced S4 cleavage in calcsilicate-rock and psammite at Hall Bay (NO 8994 8985). View to the south-west down the plunge of the F4 folds.

(b) S1 cleavage is steeper than bedding in beds that young south and are therefore inverted and downward facing on S1. Exposure at high-water mark just south of promontory at edge of main part of Perthumie Bay (NO 8908 8811). (Photos: C.W. Thomas, BGS Nos. P 726595 and P 726596.) 
Figure 4.1

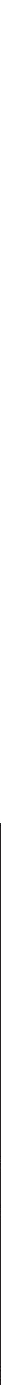


Figure 4.2

\section{SW}

(a) (b)

Cowal peninsula to Loch Lomond

$$
\text { A'-A, B'-B }
$$

North-west of the Aberfoyle Anticline

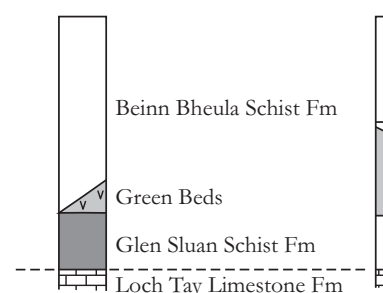

(2) (3)

(3)

GCR sites

Aberfoyle Anticline (* formations unique to SE limb)

Arran

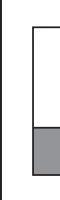

North Sannox

Grits Fm

Loch Ranza

Slate Fm

GCR sites

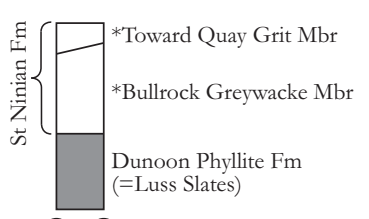

(1) (2) (c)

Aberfoyle

C'-C

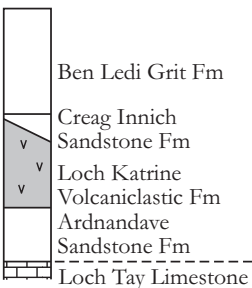

(4) $5 \mathrm{Fm}$ (d)

Pitlochry to Dunkeld

E'-E

!

i

NE

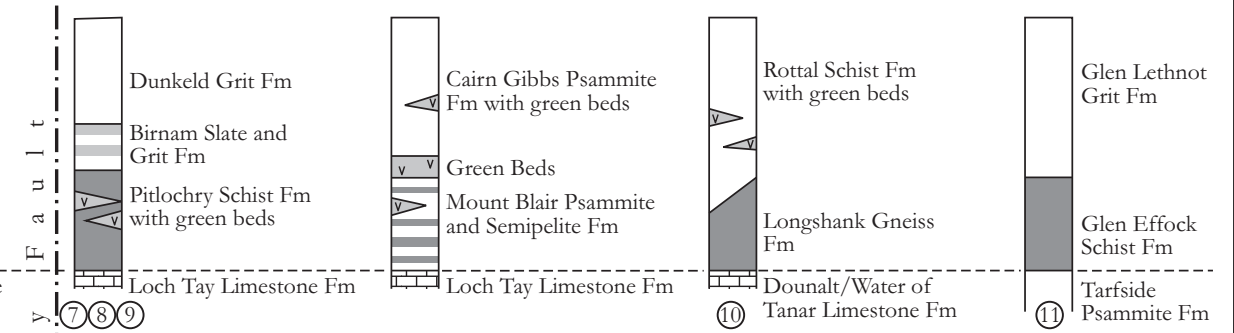
!

$\mathrm{Hi}$

Callander

$=$ I D'-D

*Keltie Water Grit Fm,

including Keltie and Leny

limestone and slate members

(e)

Glen Shee

F'-F

(f)

(g)

Glen Esk (Tarfside Nappe) to Stonehaven G'-G

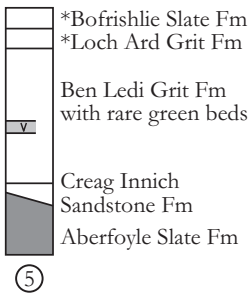

$\measuredangle$ Ben Ledi Grit Fm,

including prominent

3 pelites/semipelites

(10) Tanar Limestone Fm

(11) Psammite Fm

i

(6)

psammites/metagreywackes

pelites/semipelites

I독

的

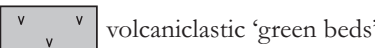




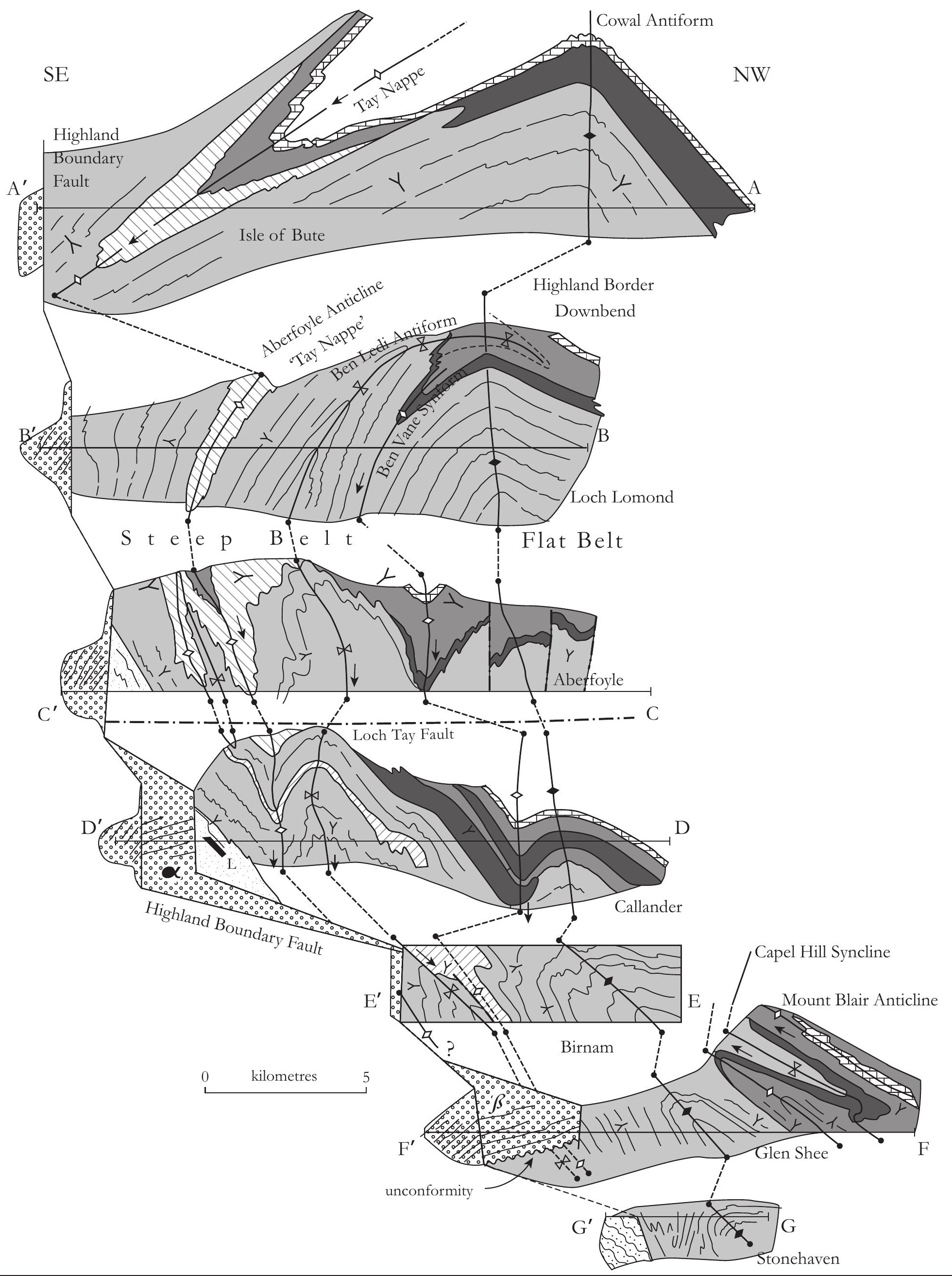

Figure 4.4 
Figure 4.5

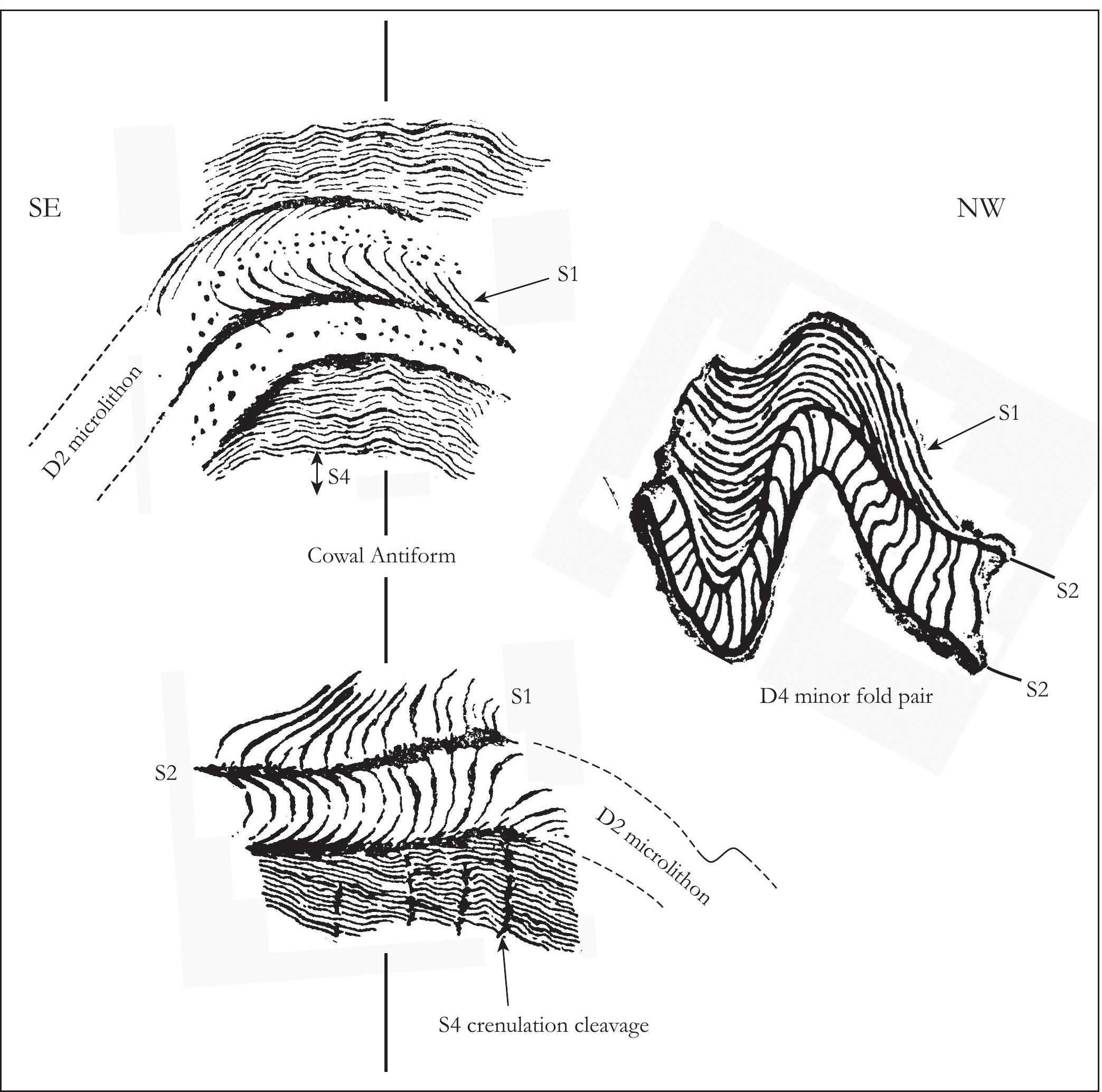




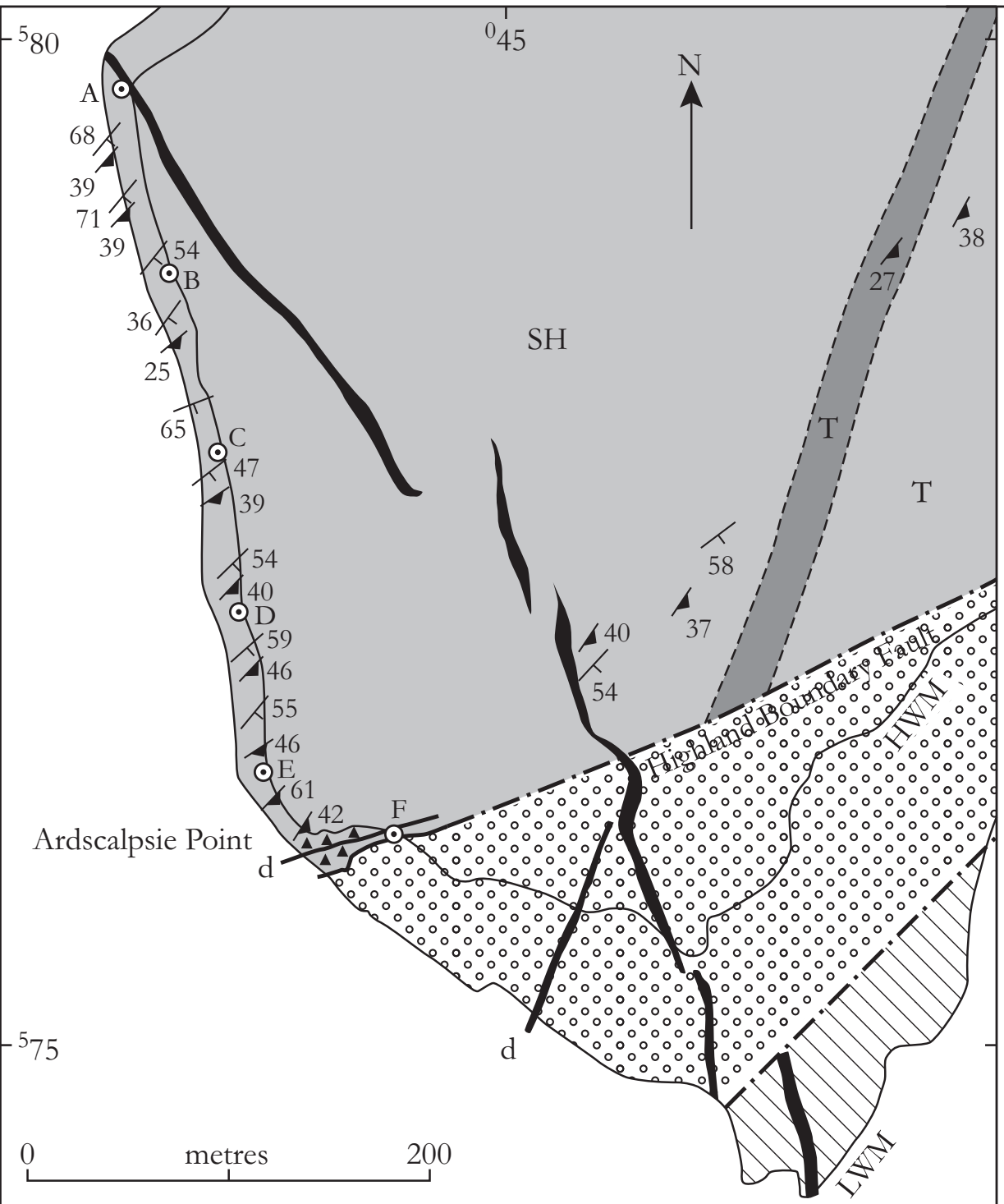

quartz-dolerite dyke (Palaeogene)

d unclassified dyke (?Early Carboniferous)

M (?)basic sill (?Early Carboniferous)

Lower Carboniferous, Kinnesswood Formation

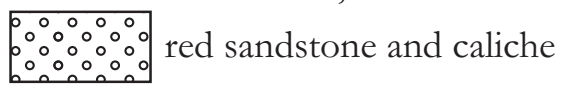

Dalradian Supergroup,

Southern Highland Group (SH)

and Trossachs Group (T)

$\square$

dark grey slaty pelite

well-bedded metagreywacke

A breccia associated with the splay from

A the Highland Boundary Fault

$\perp \quad$ inclined bedding, dip in degrees

ـ inclined slaty and spaced S1 cleavage, dip in degrees

LWM, low and high tide marks
HWM

$-\cdot-\cdot-$ fault 


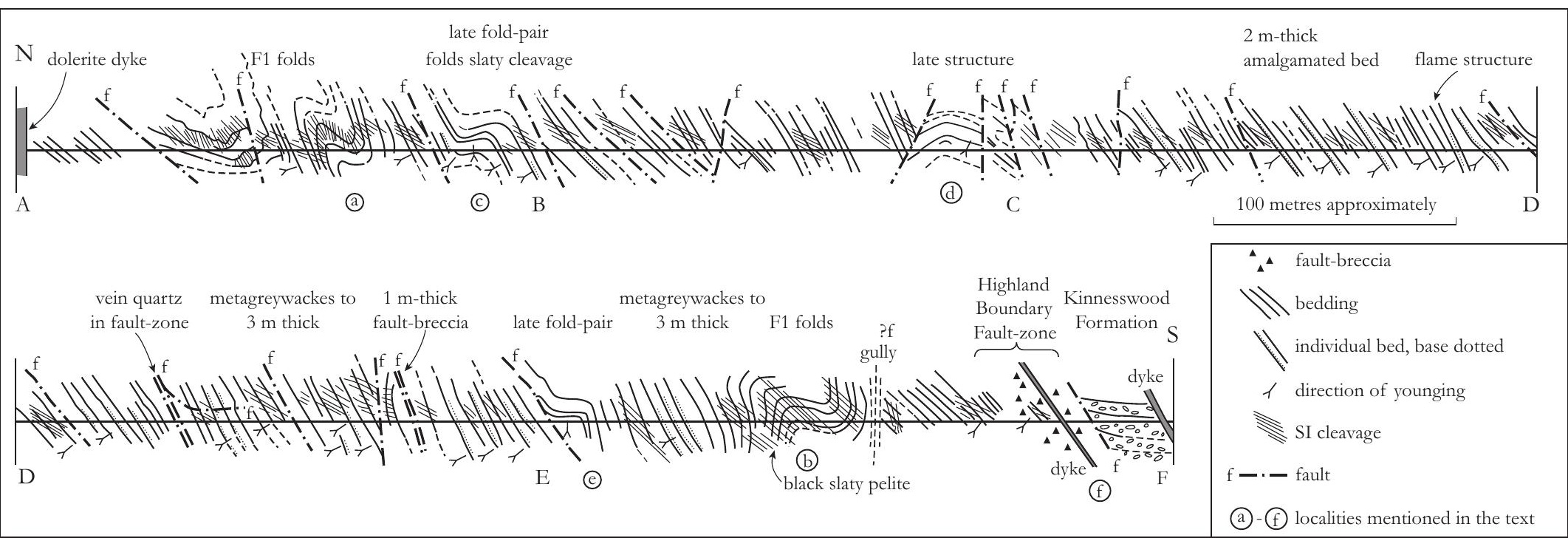


Figure 4.11

(a)
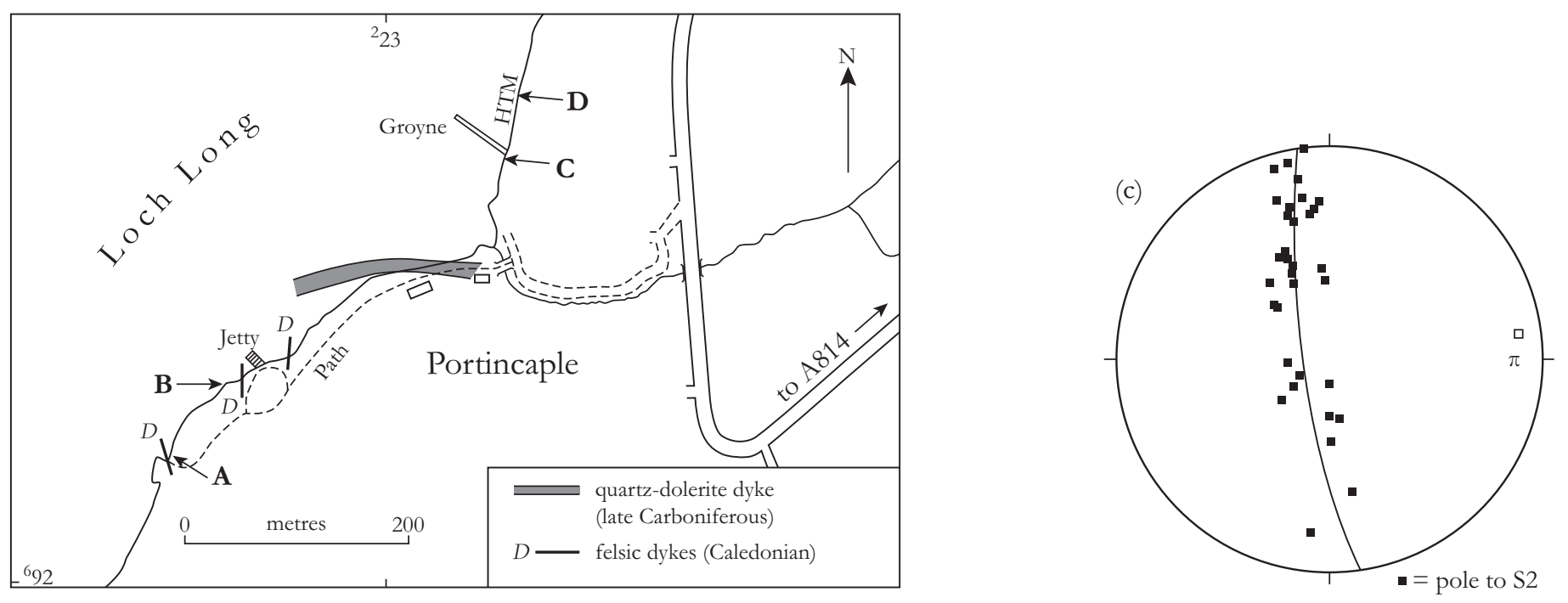

(b) $\mathrm{N}$

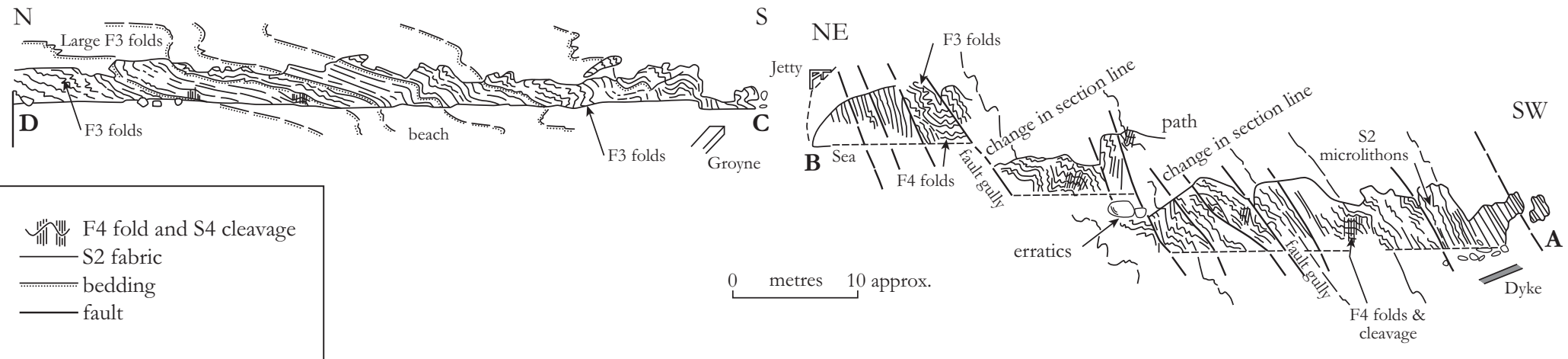




\section{Figure 4.13}

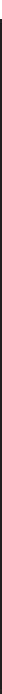

Keltie Water Grit
Ben Ledi Grit with
Aberfoyle Slate etc.
green beds




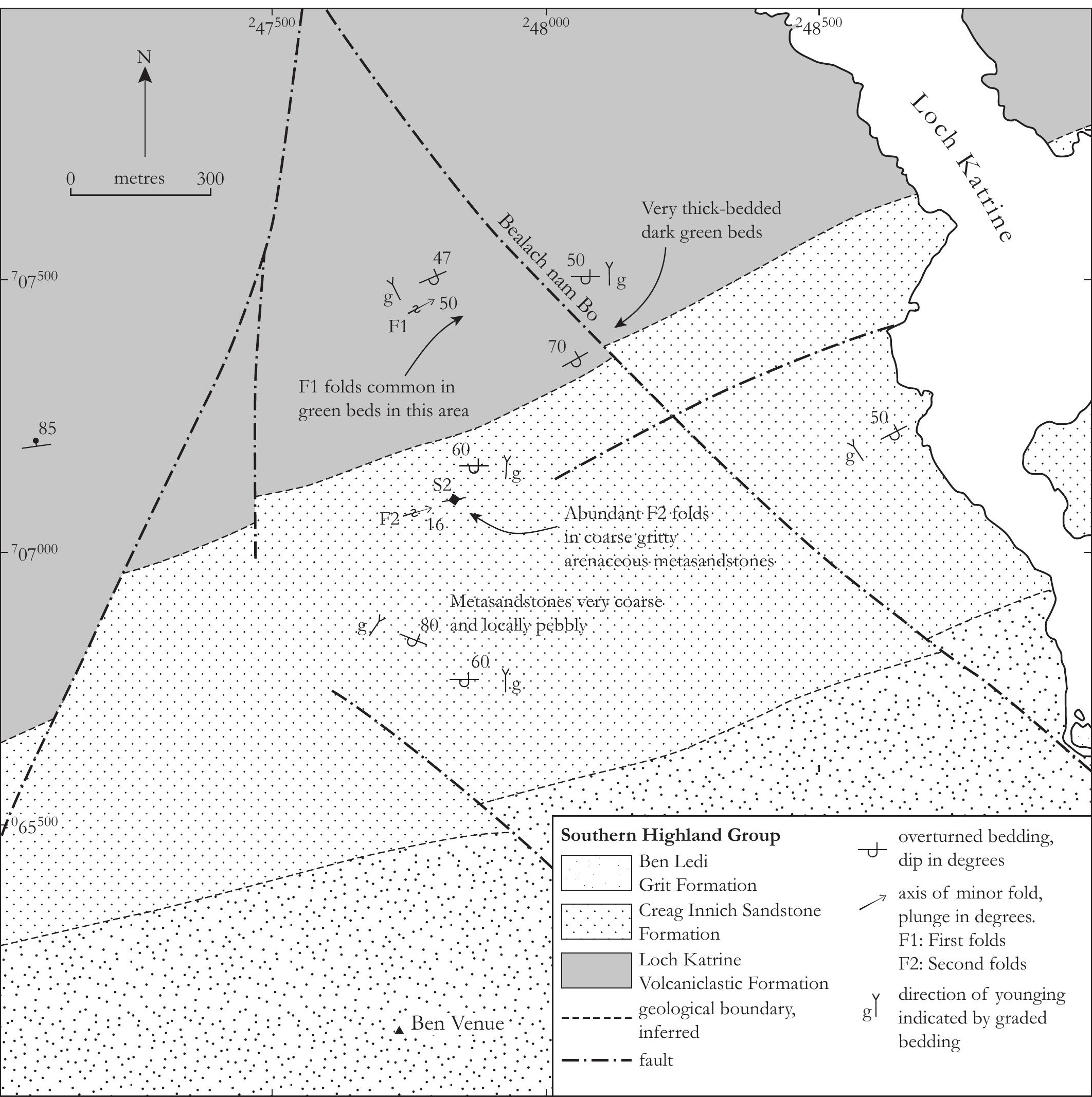


Figure 4.15

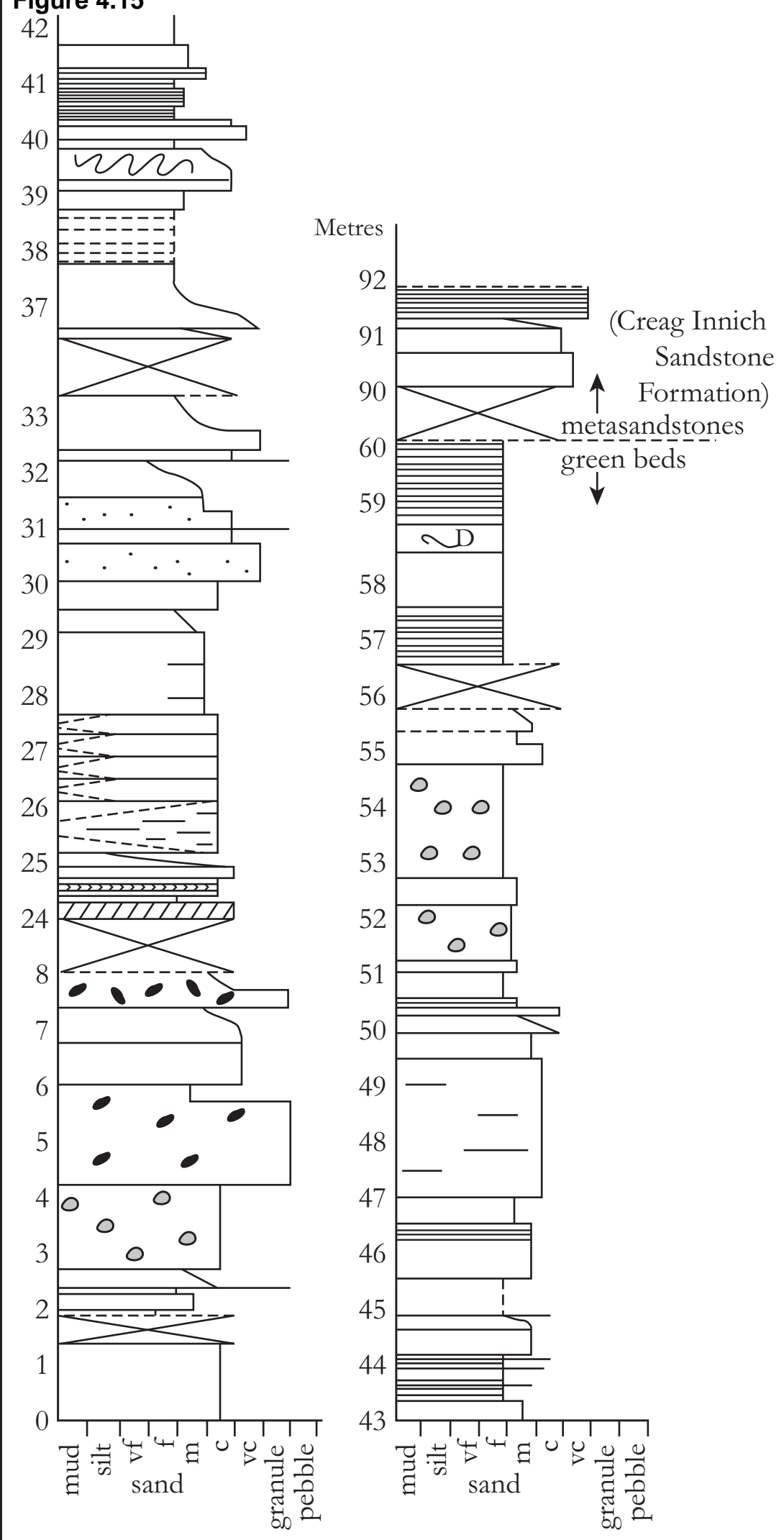

$\therefore$ quartz pebbles

herringbone cross-lamination

////// cross-lamination lenses

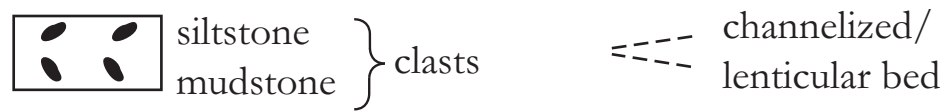

$\sim$ dewatering

Un slumping 
Figure 4.18

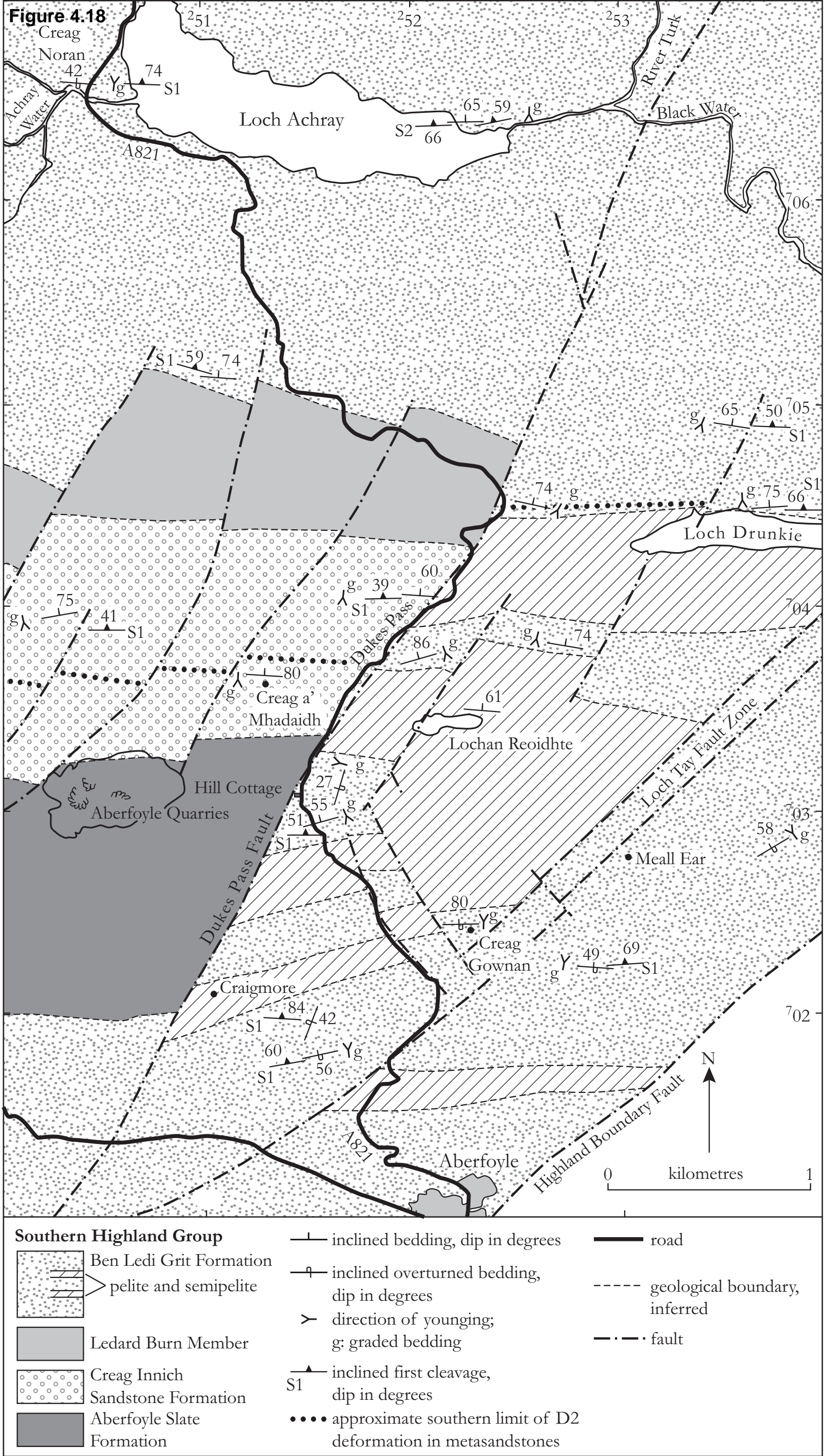


Dalradian Supergroup: key units in approximate stratigraphical order, formed by combining the different sequences found on the limbs of the Tay Nappe (see Fig 4.2 for details).

Keltie Water Grit Formation (with Leny Limestone, L)

Birnam Slate and Grit Formation

Aberfoyle Slate Formation (=Luss Slates and Dunoon Phyllites)

Beinn Bheula Schist Formation, St Ninian Formation, Ben Ledi Grit Formation etc.

green beds

Glen Sluan Schist Formation etc.

Loch Tay Limestone Formation

fault-bounded panels of Lower Old Red Sandstone strata north-west of the Highland Boundary Fault.
Lower Devonian, Upper Devonian and Lower Carboniferous (ORS facies)

Highland Border Ophiolite

$>\quad$ younging direction

$>$ generalized younging direction

facing direction of early (F1) major fold

_ form line (generally bedding)

$\nabla \checkmark$ axial plane trace of early fold

$\checkmark$ axial plane trace of later fold

-------• correlation tie-line

- $-\cdot$ minor fault 


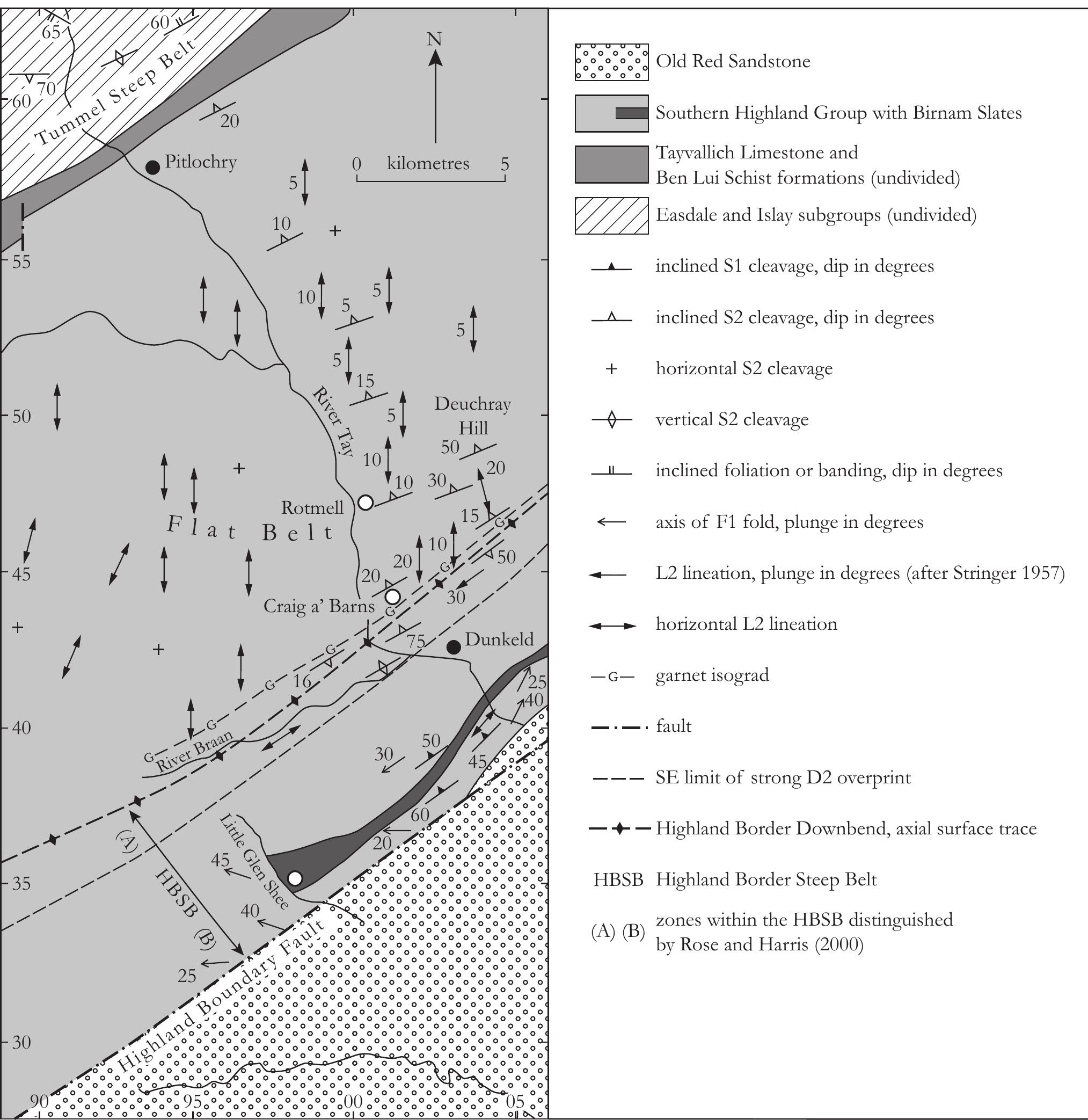




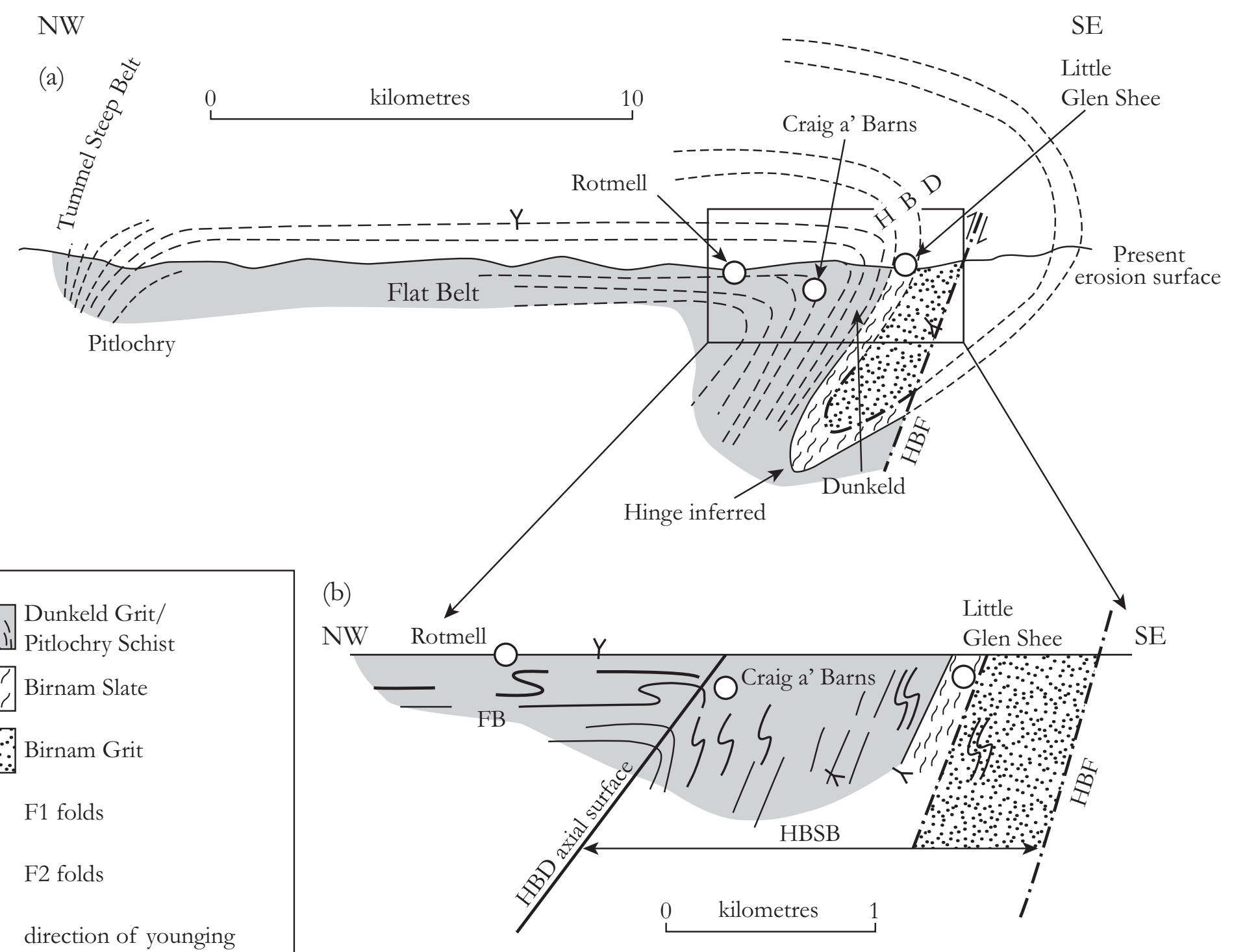

Eニニミミ゙ Dunkeld Grit/
Eシミミl, Pitlochry Schis

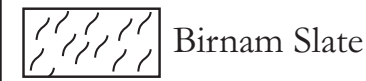

$\therefore$
SS F1 folds
S F2 folds
$\uparrow \quad$ direction of younging

(b) 


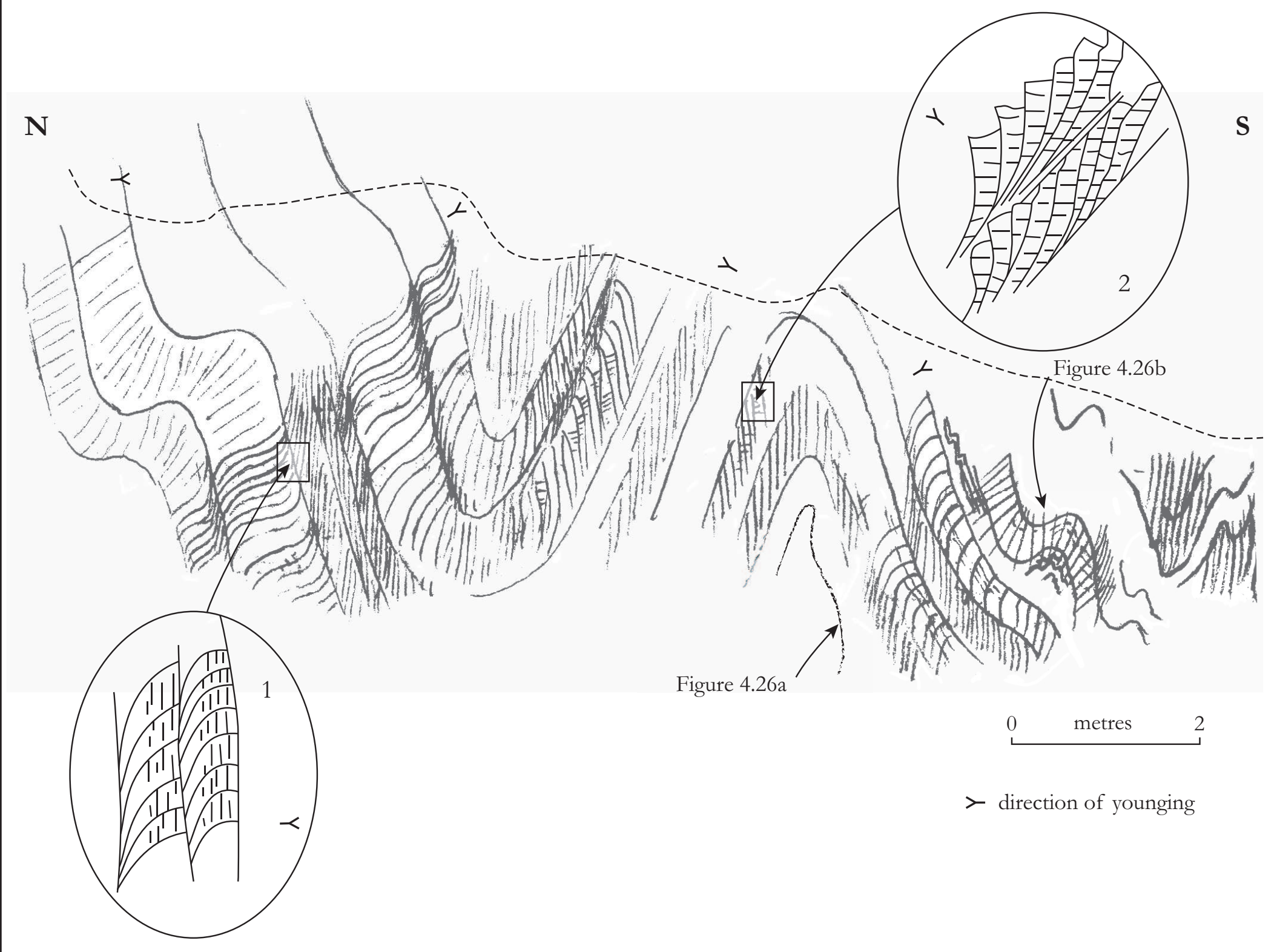




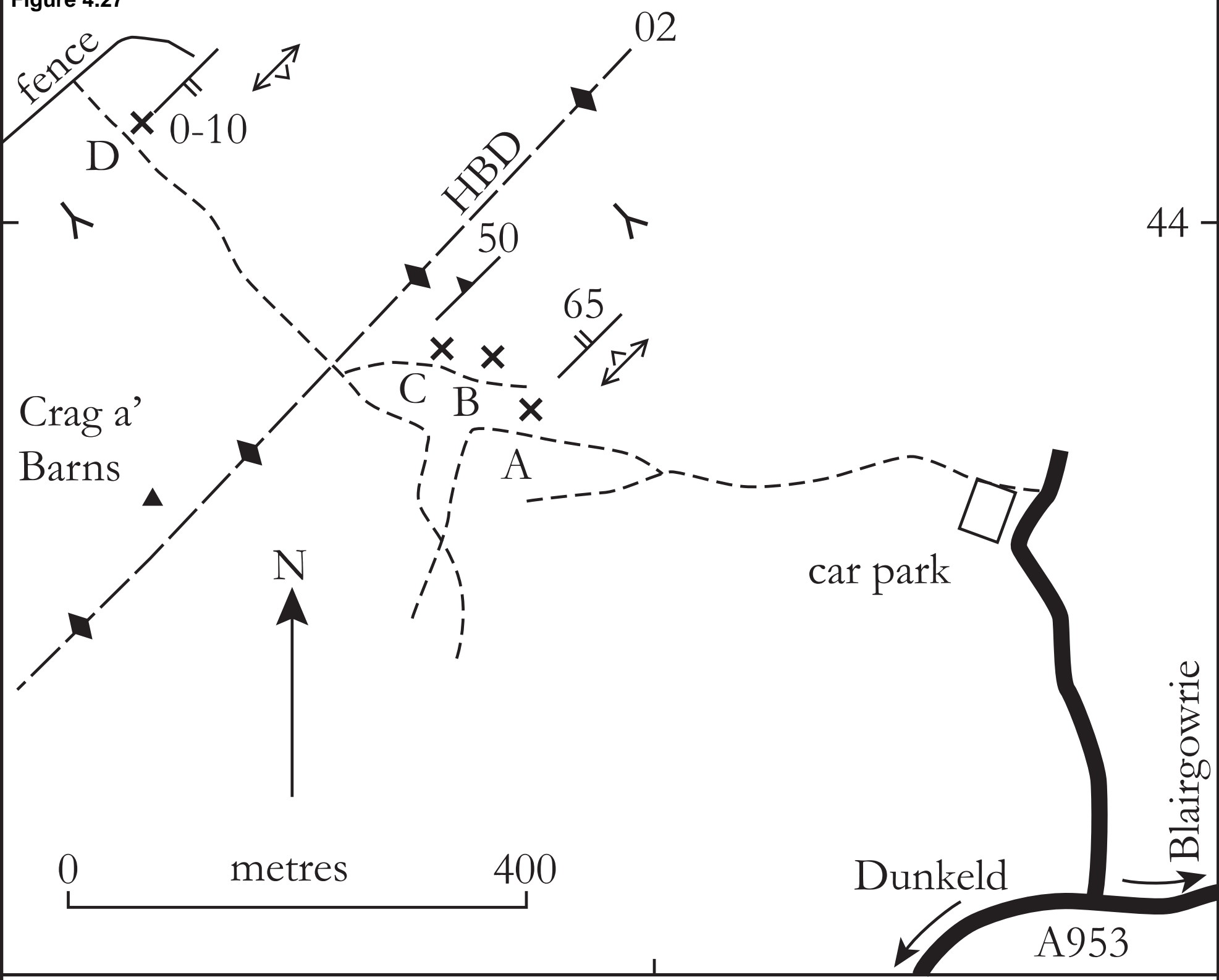

- inclined composite foliation of S $\varnothing, \mathrm{S} 1$ and S2 on long limbs of F4 folds, generalized dip in degrees

__ inclined S4 crenulation cleavage at Highland Border Downbend hinge-zone, generalized dip in degrees

subhorizontal axis of F4 minor fold, showing direction of vergence

$-\rightarrow$ axial plane trace of major F4 antiform

$>$ general direction of younging, inferred from regional structure 


\section{Figure 4.30}

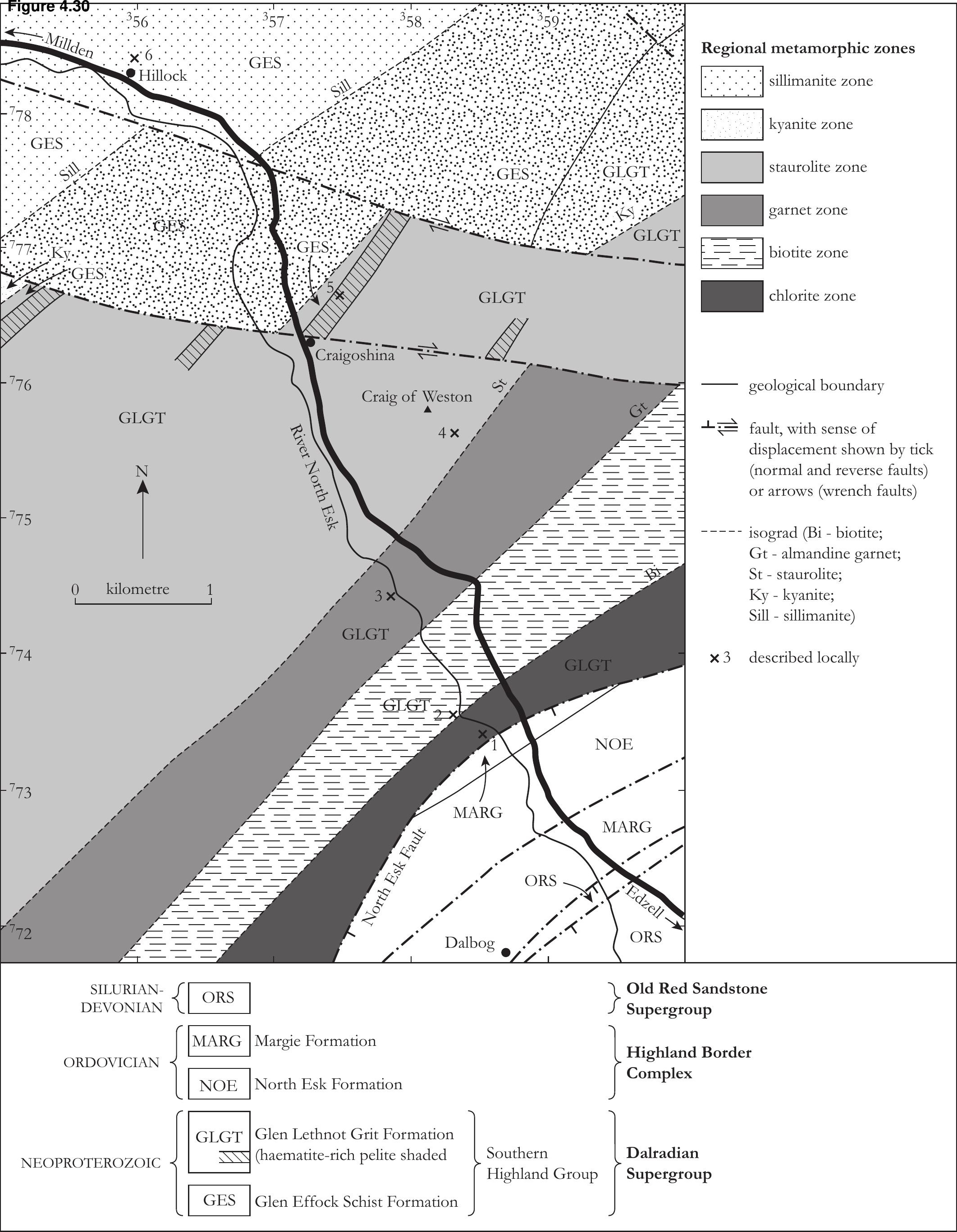


Figure 4.33

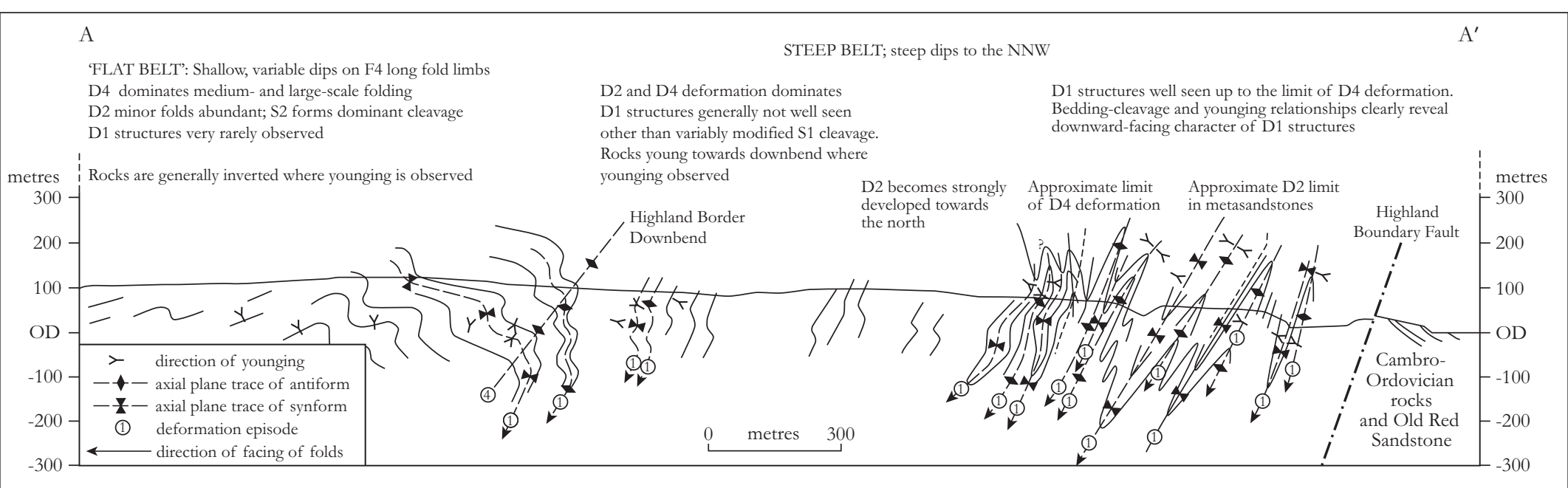




\section{Click here to download high resolution image}

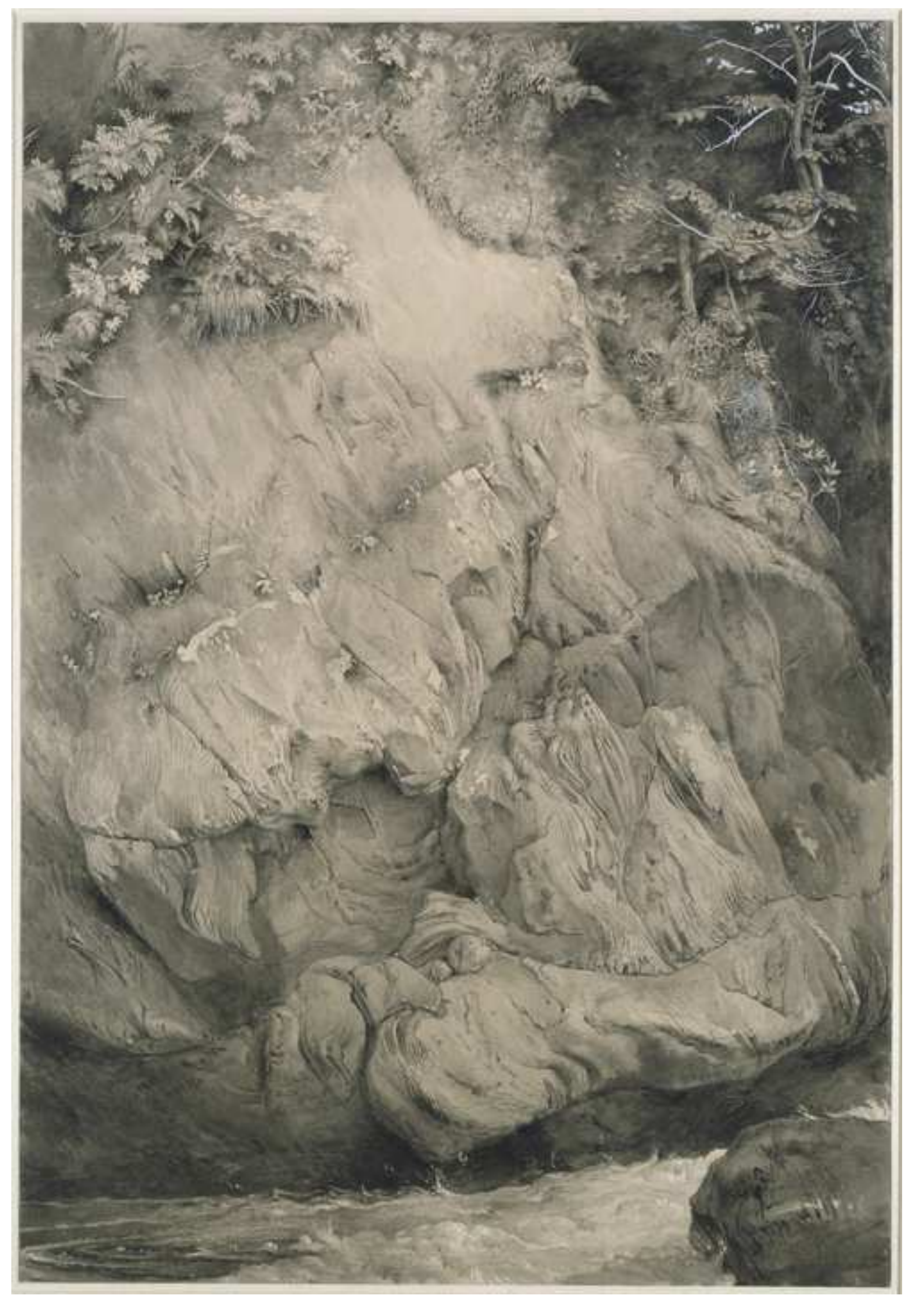

Figure 4.3 colour
Click here to dou

(

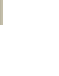




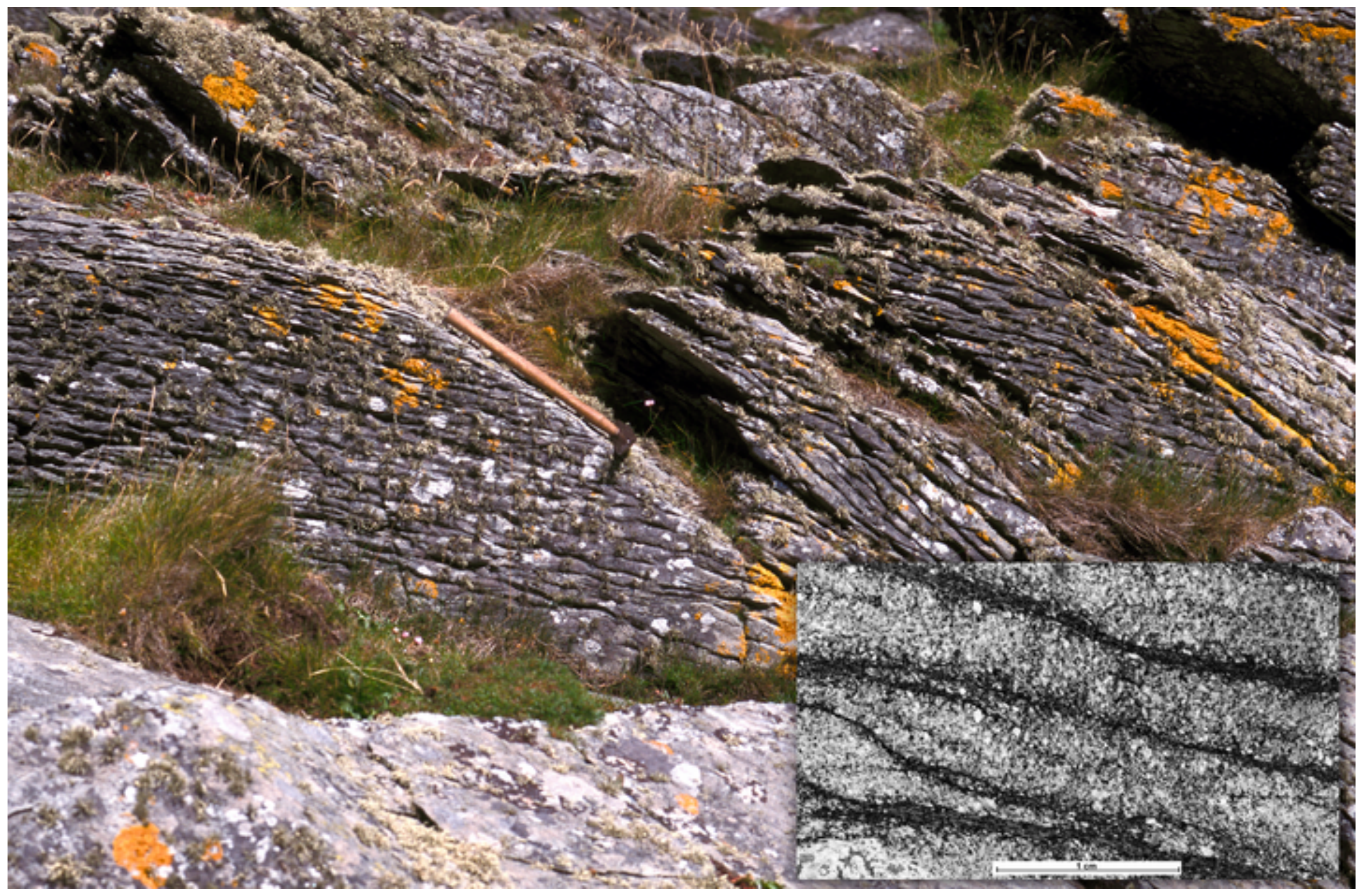


Click here to download high resolution image

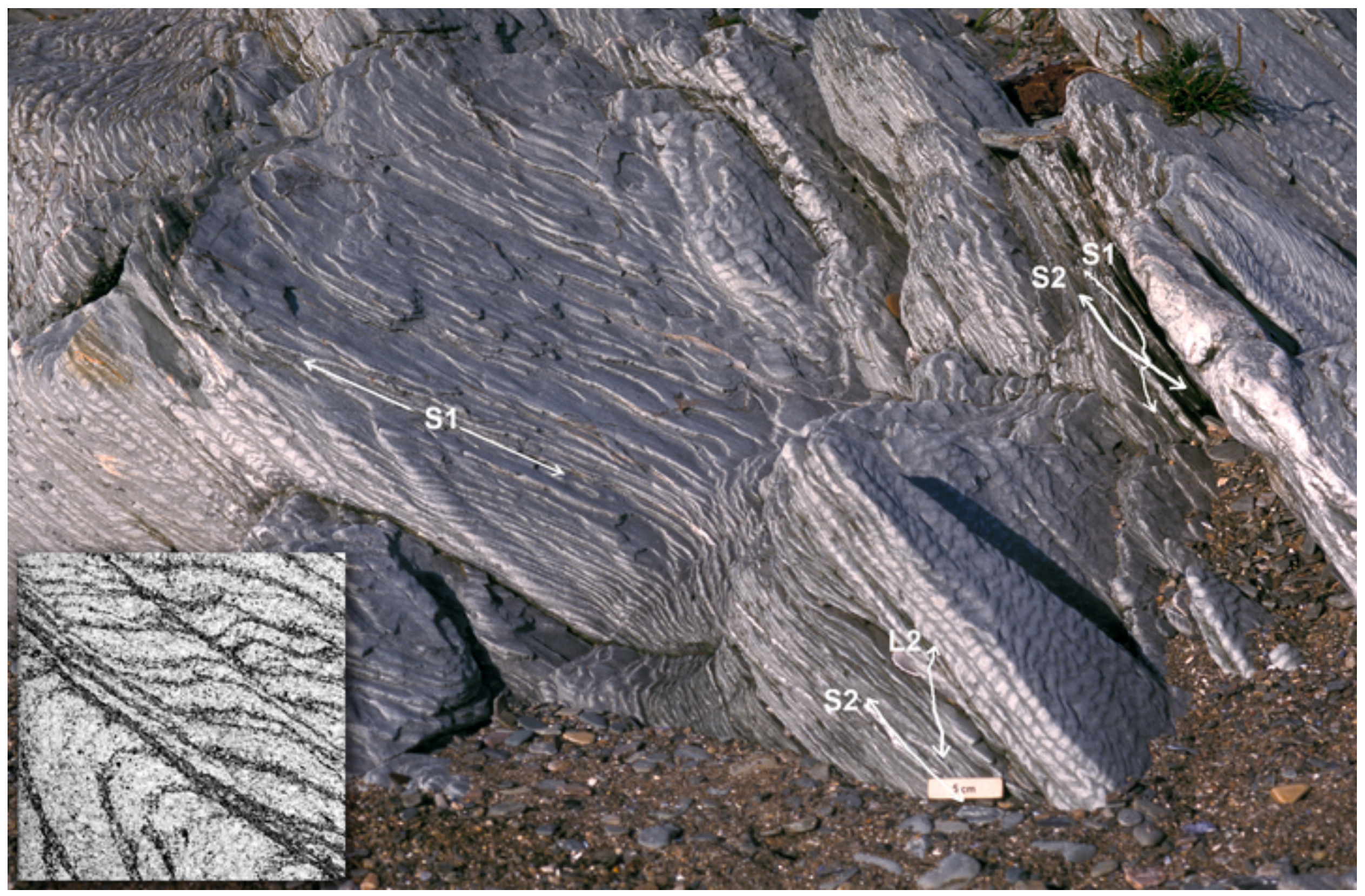




\section{Click here to download high resolution image}

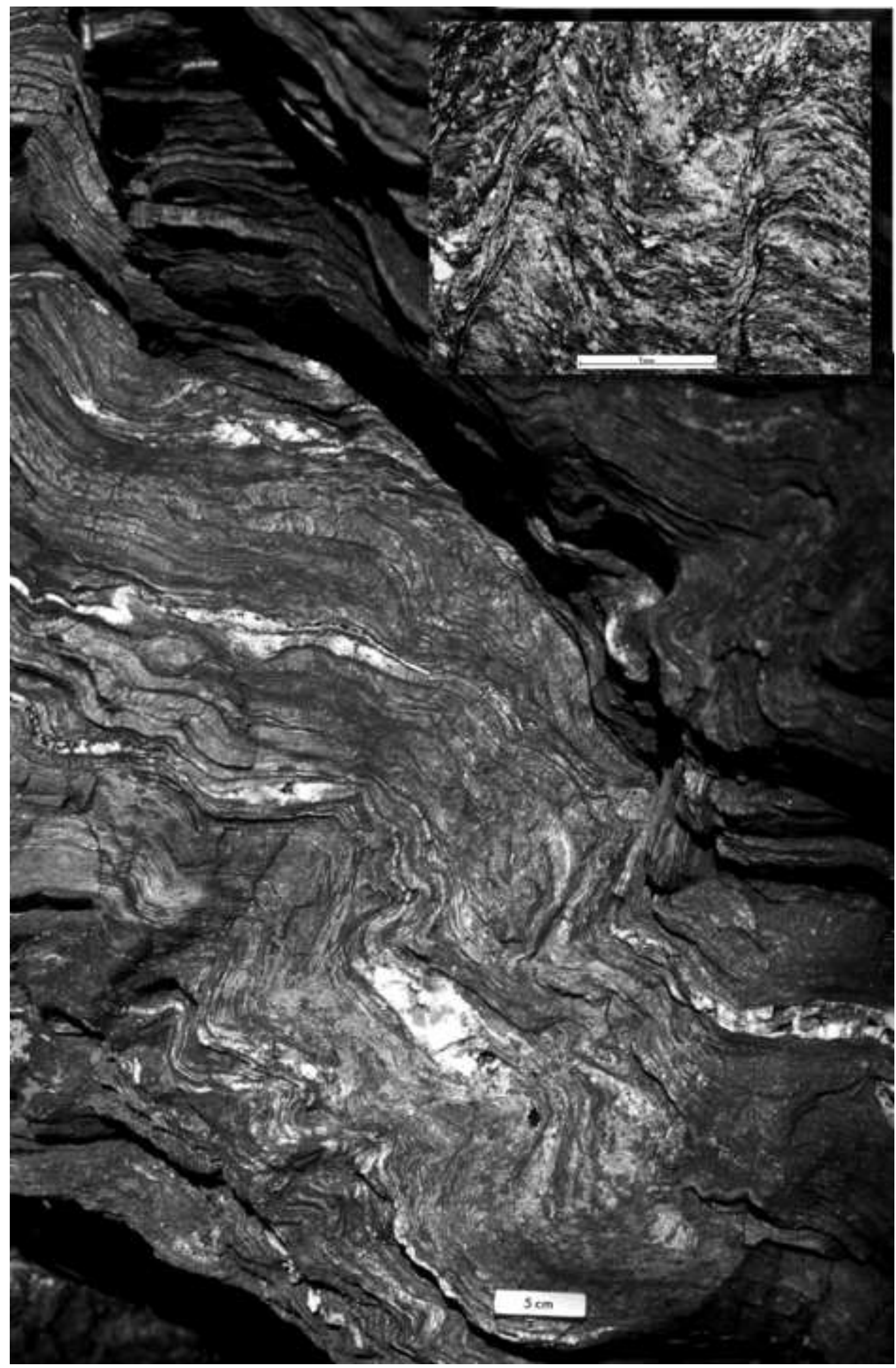


Figure 4.16 colour
Click here to download high resolution image

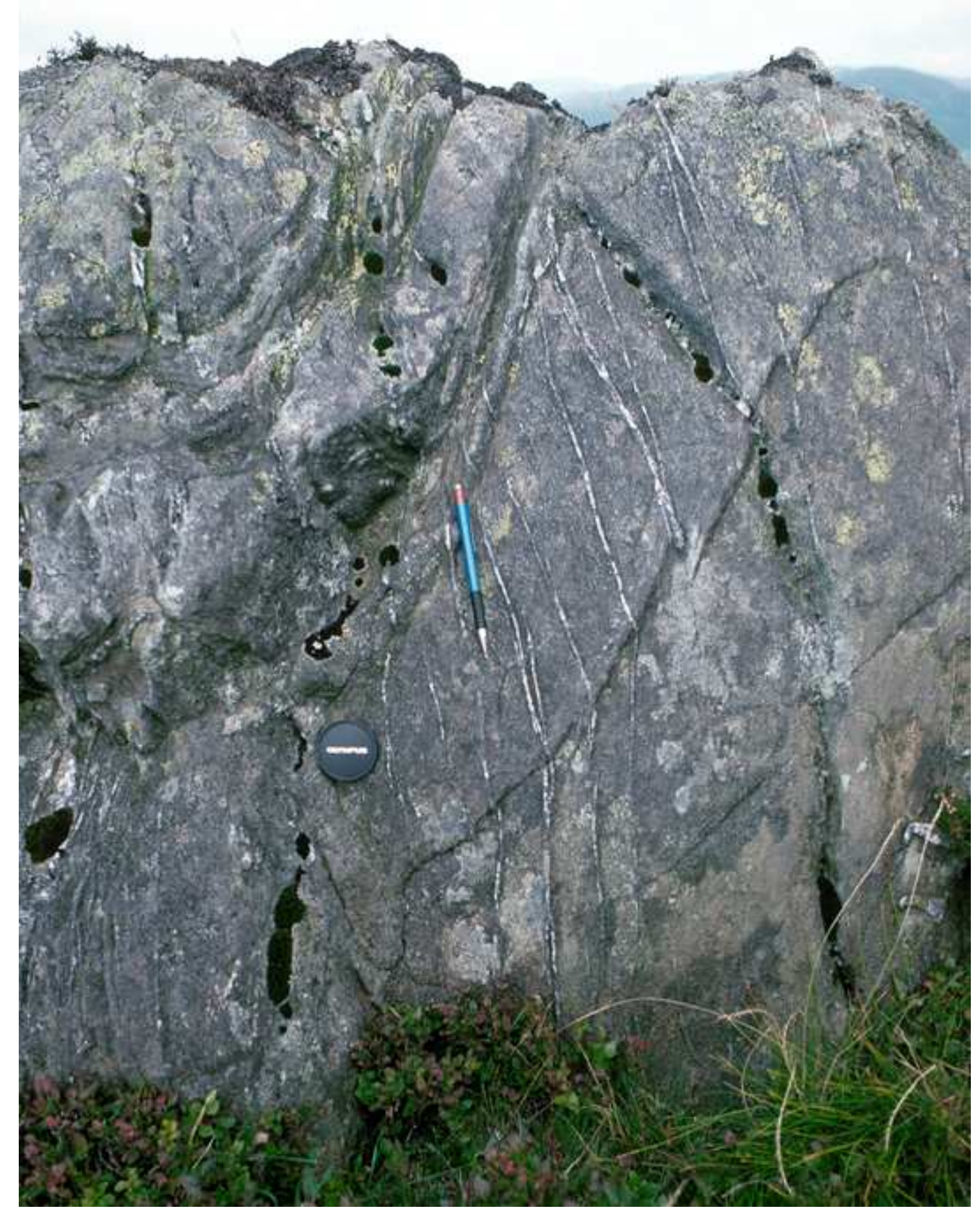

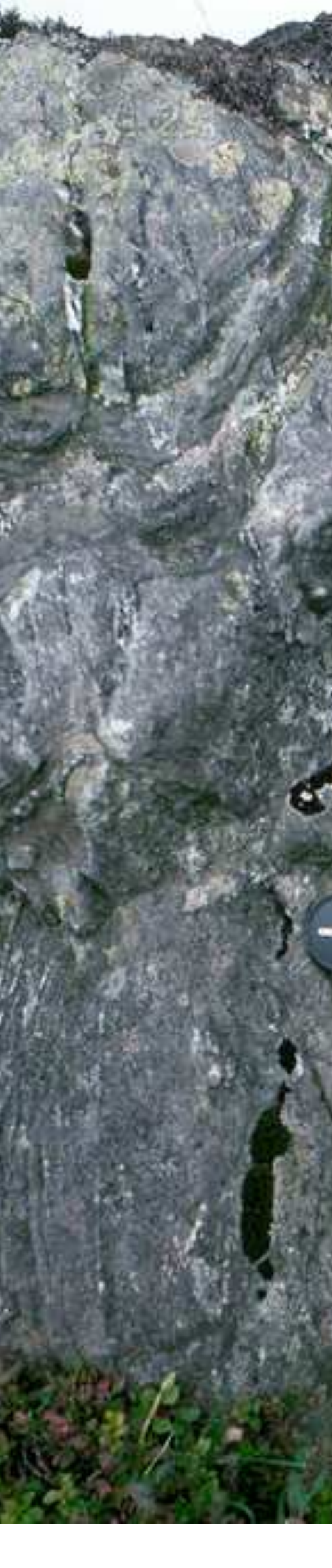


Figure 4.17 colour

Click here to download high resolution image

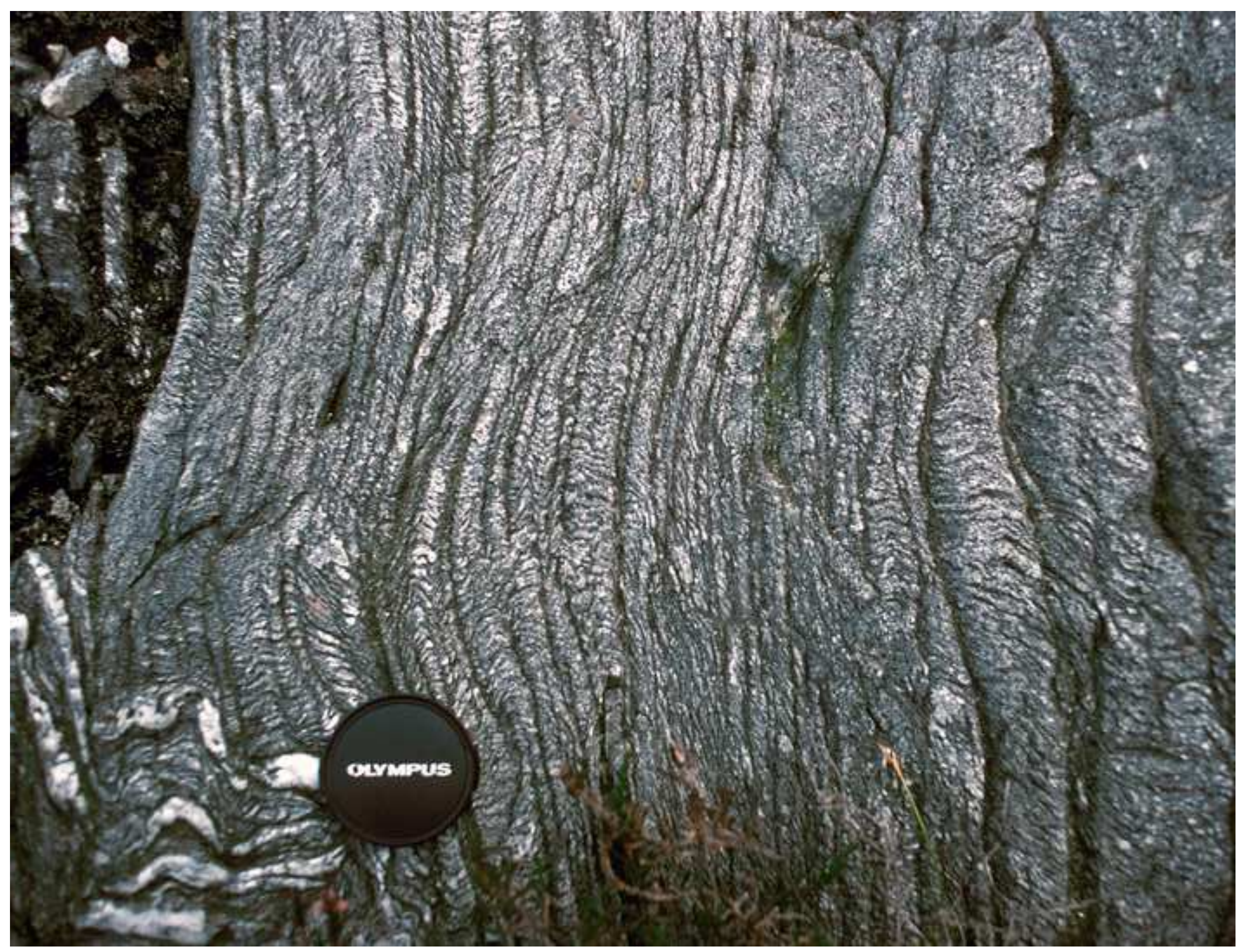


Click here to download high resolution image

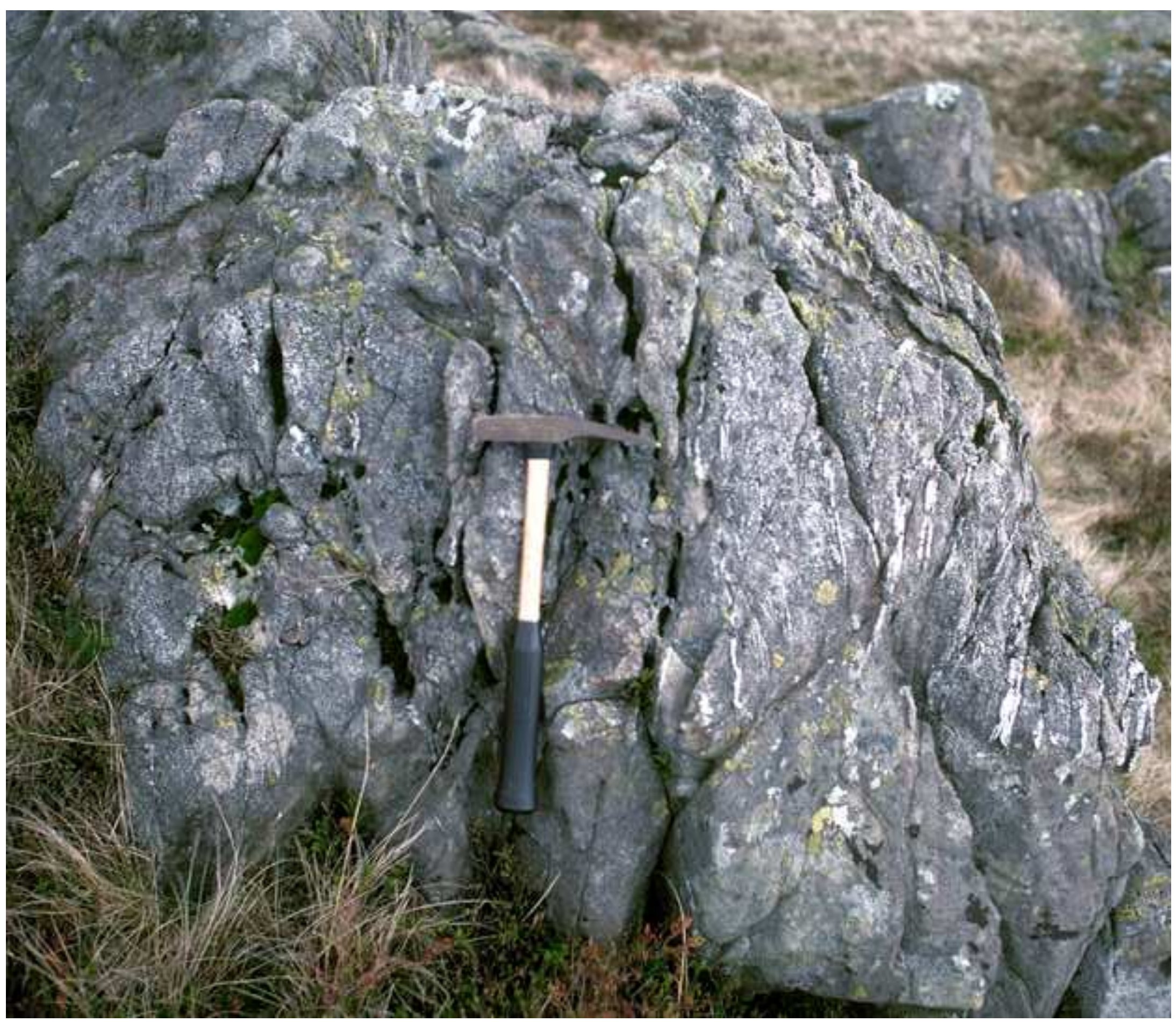




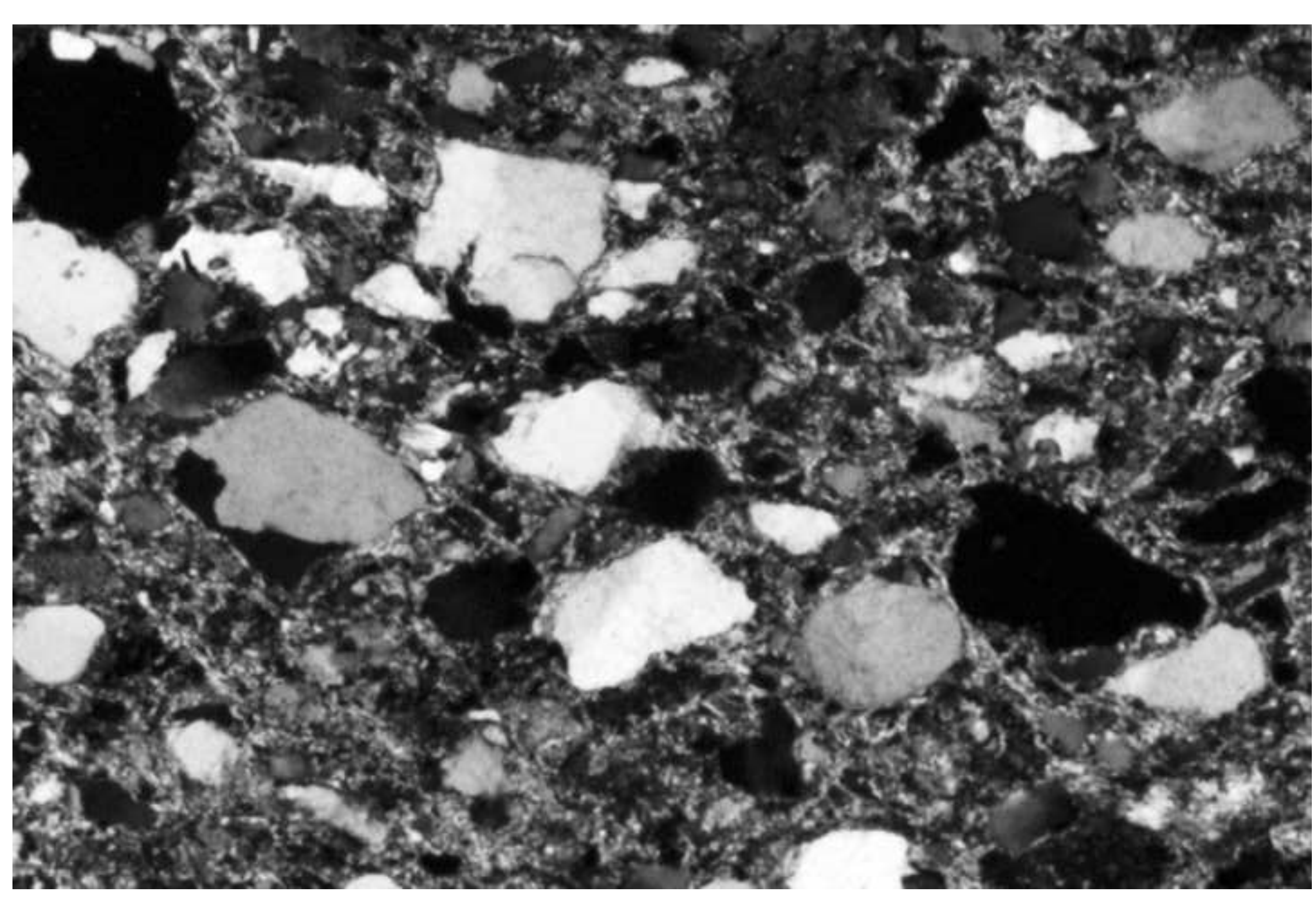




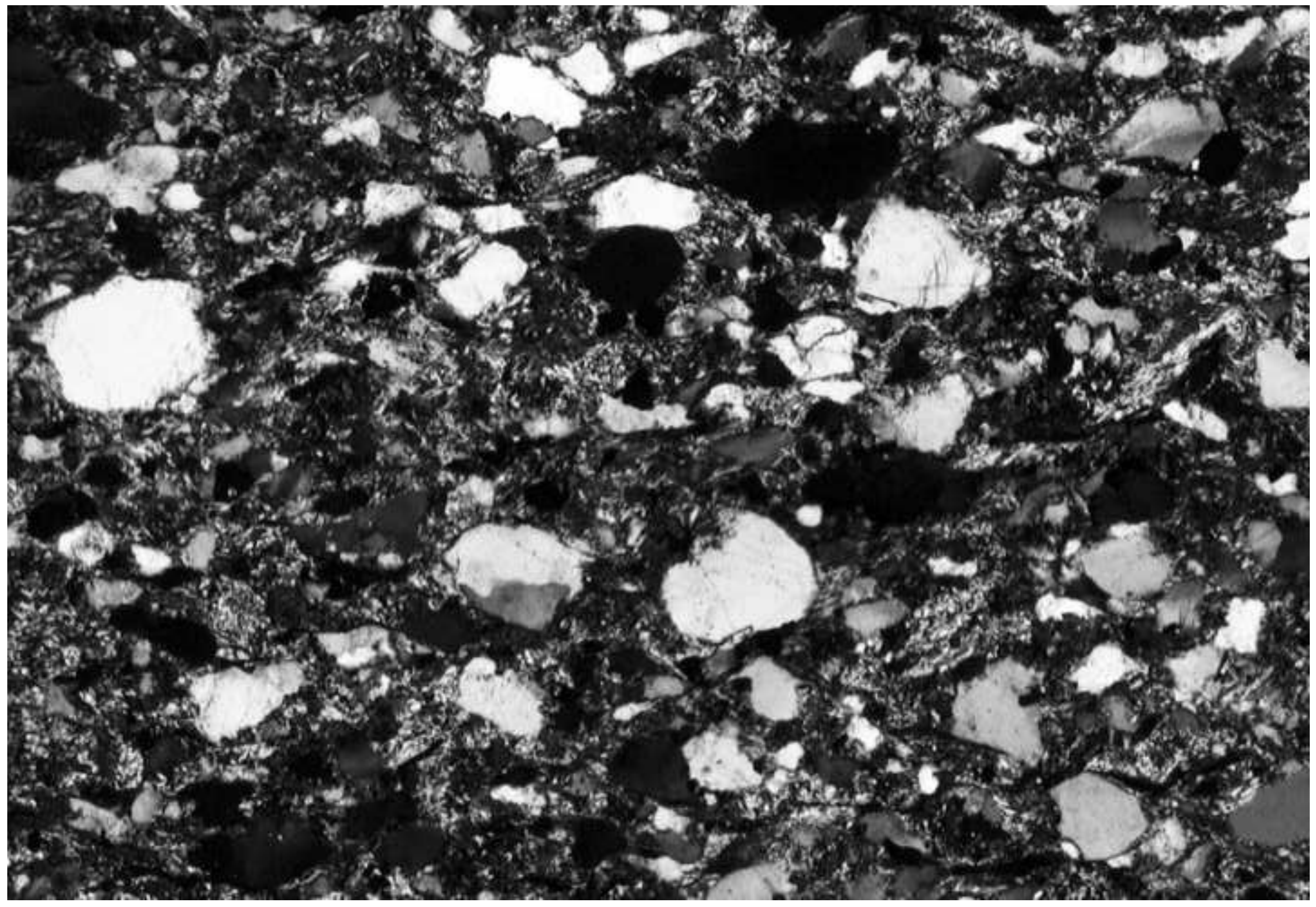


Click here to download high resolution image

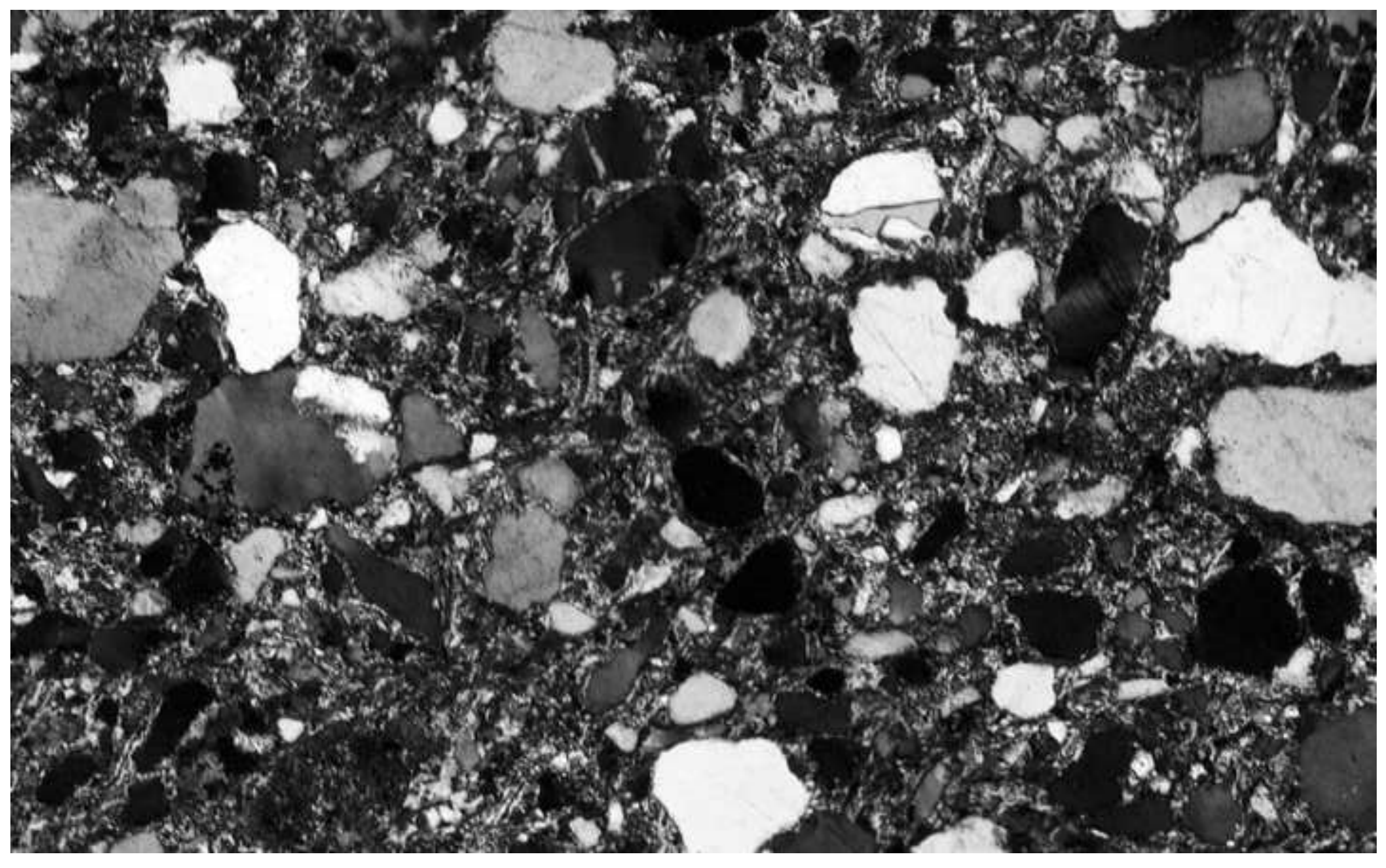


Click here to download high resolution image

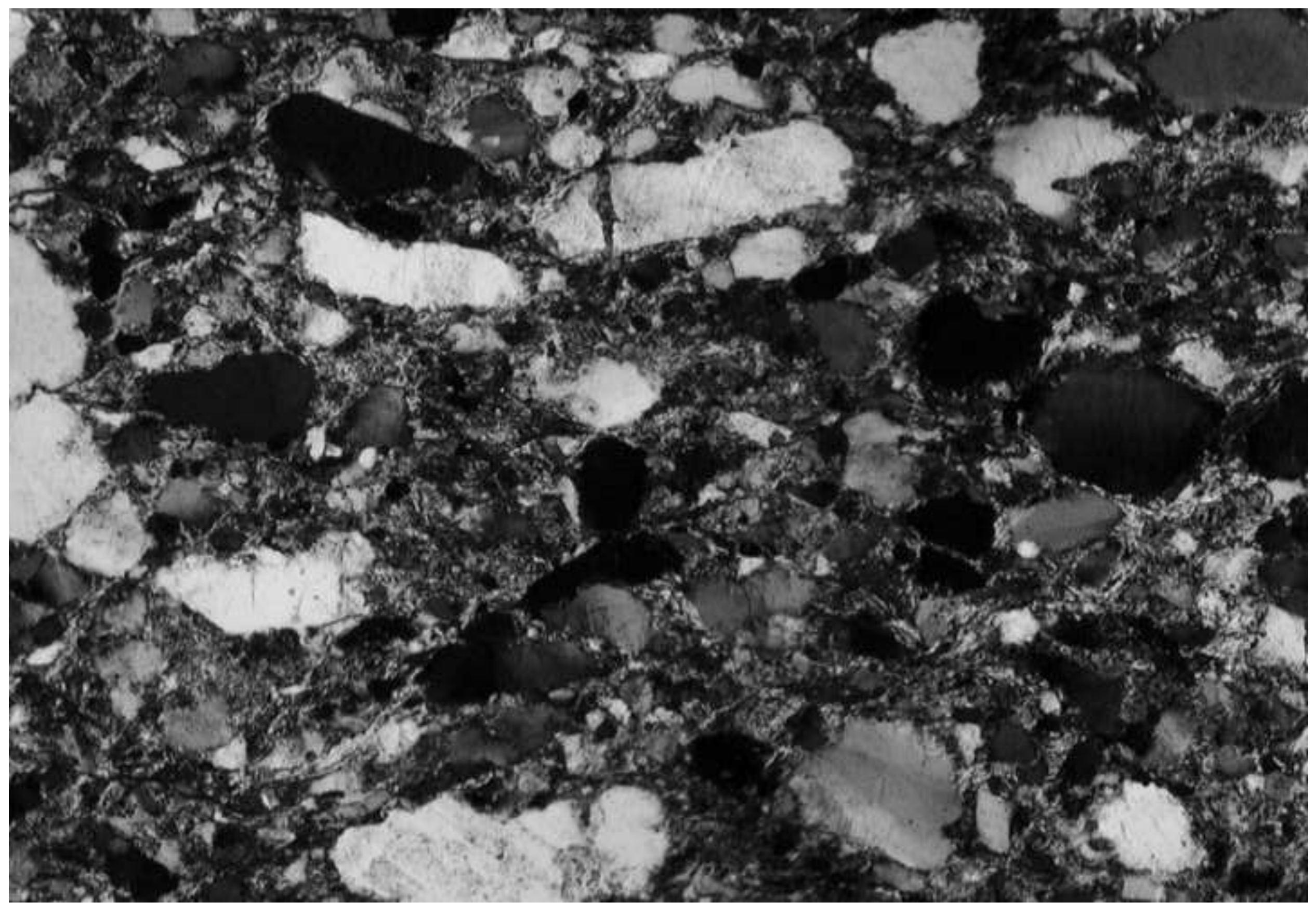




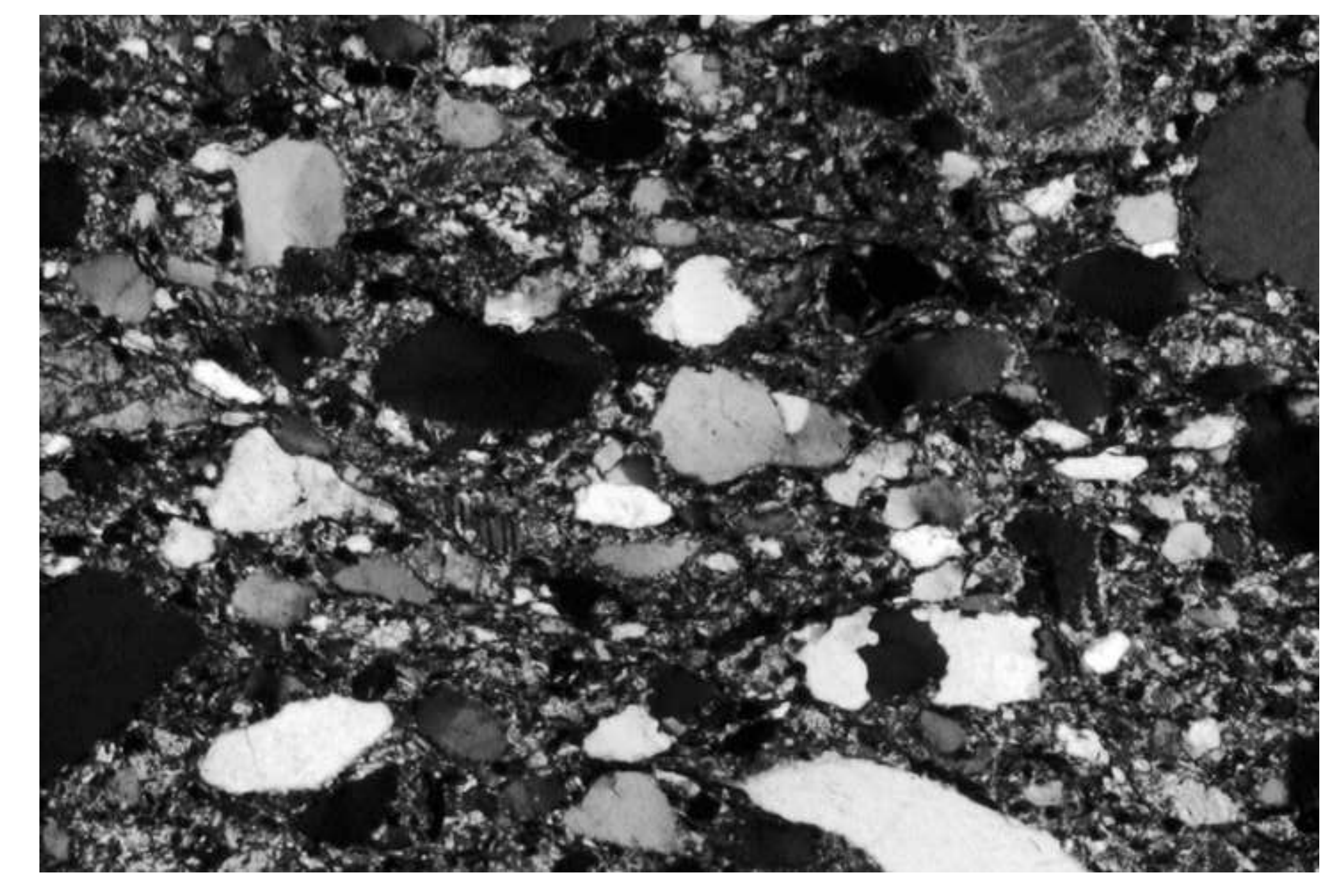






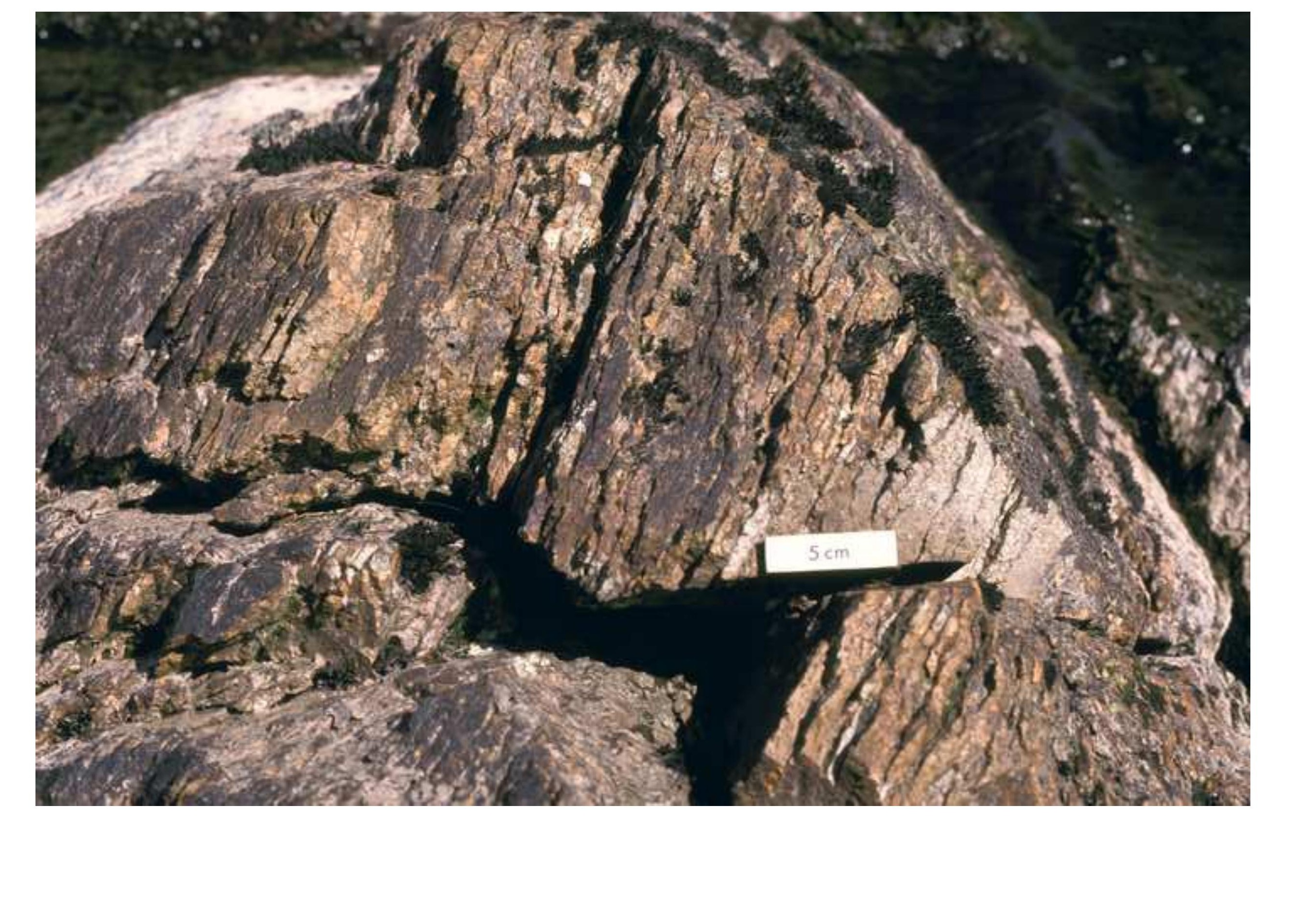

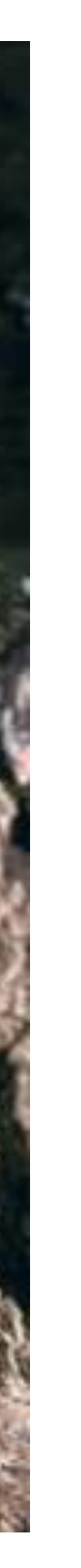


Click here to download high resolution image

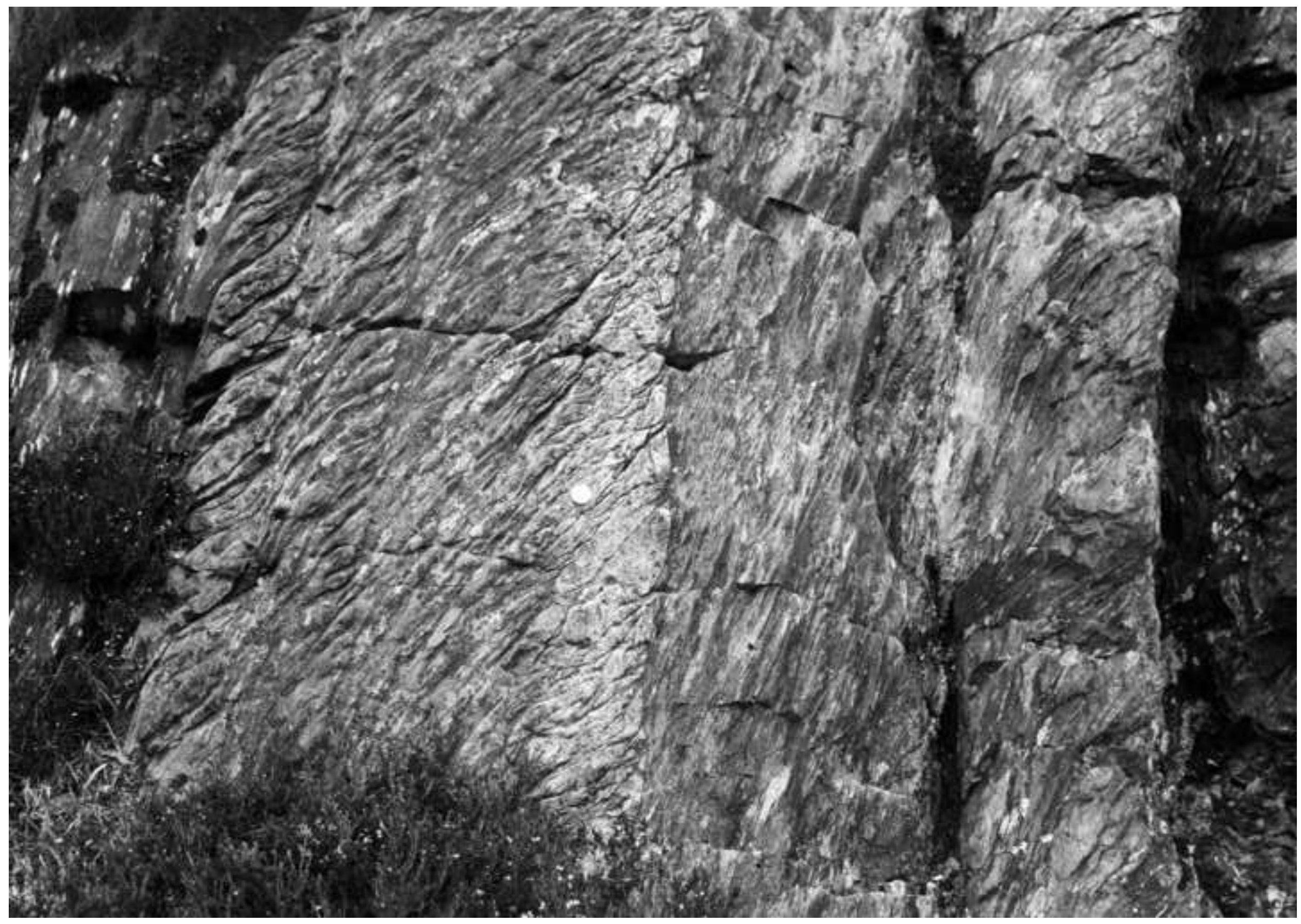




\section{Click here to download high resolution image}

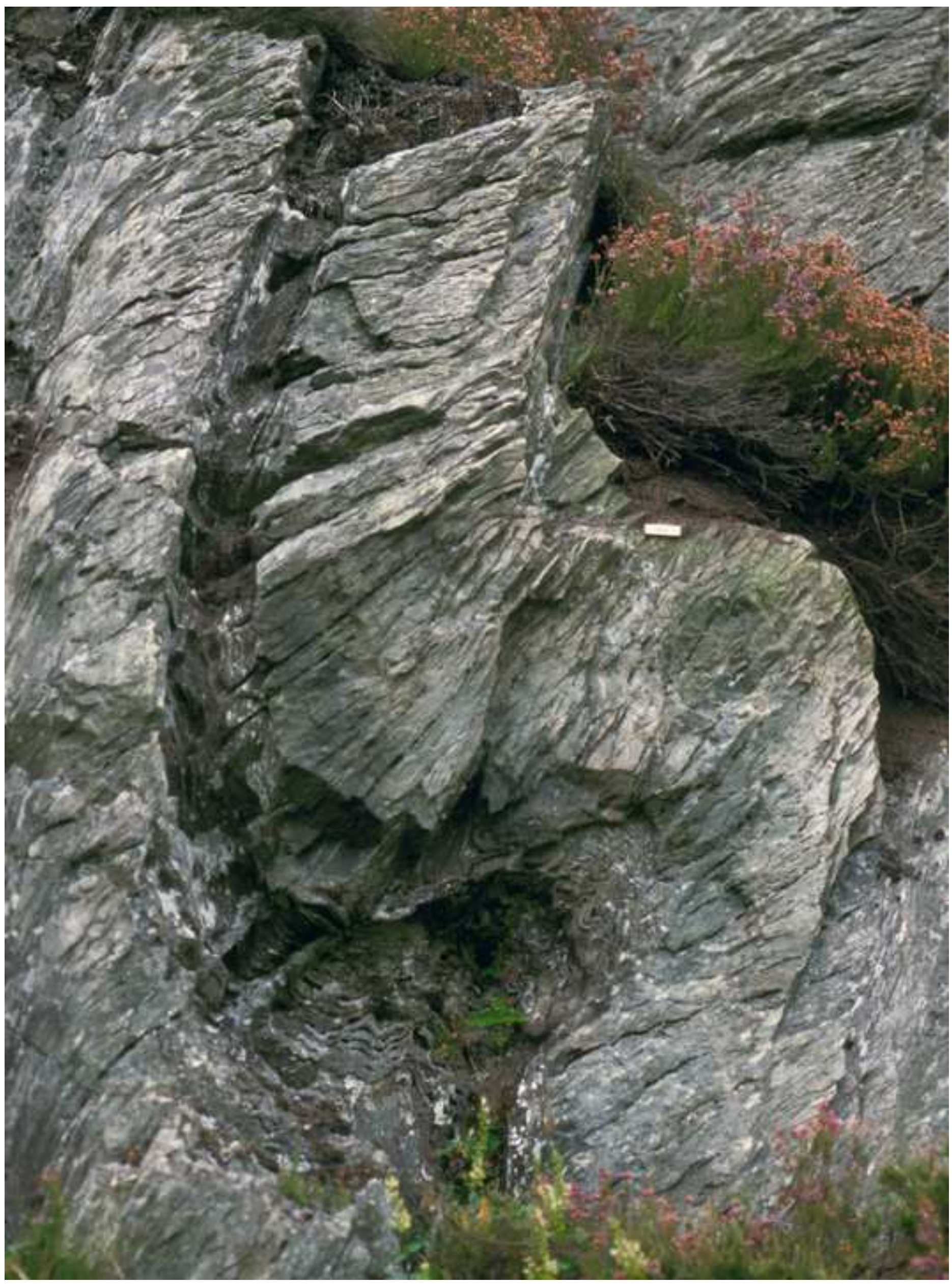




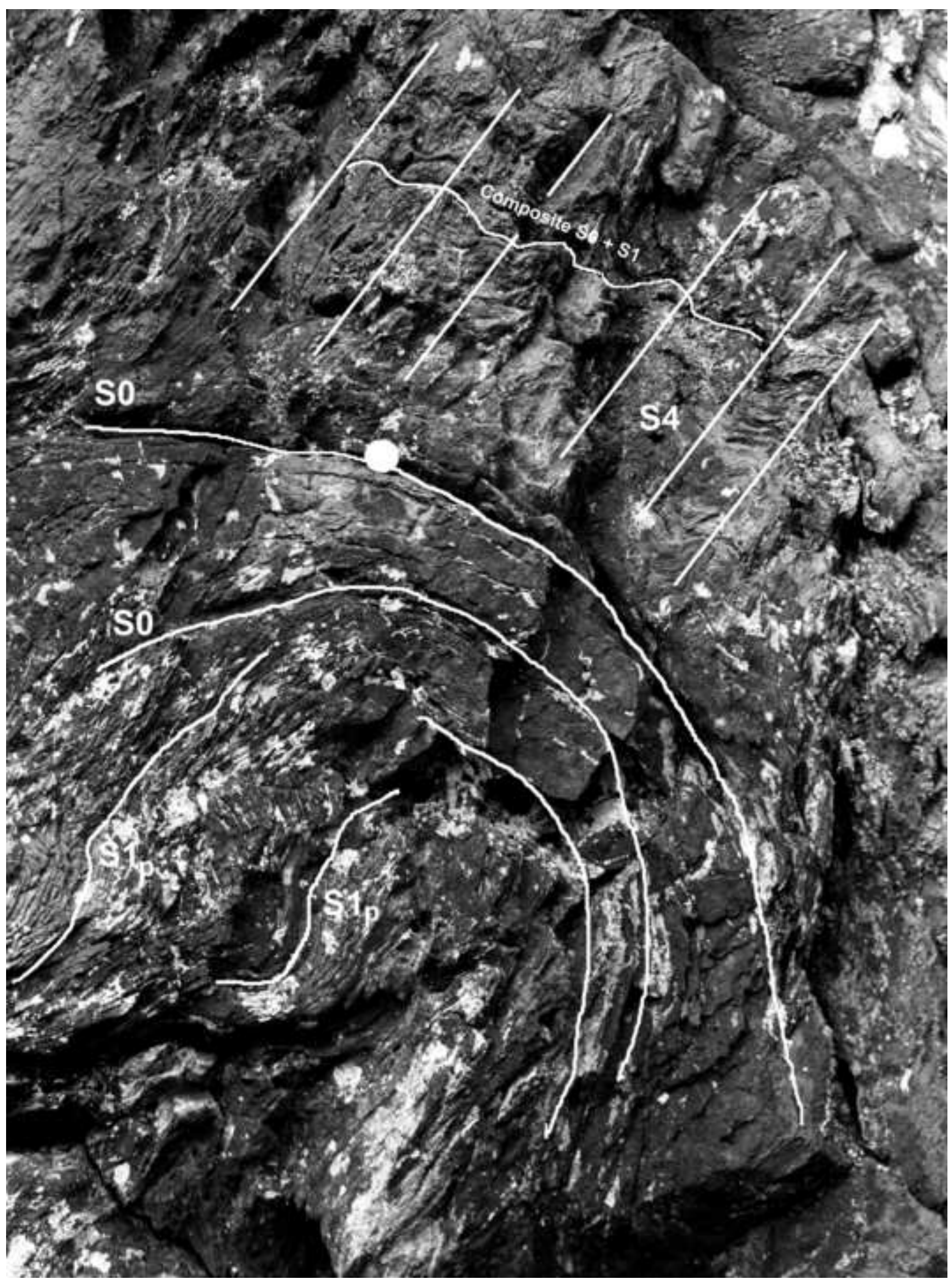

Figure $4.28 \mathrm{~b}$
Click here to download high resolution image 


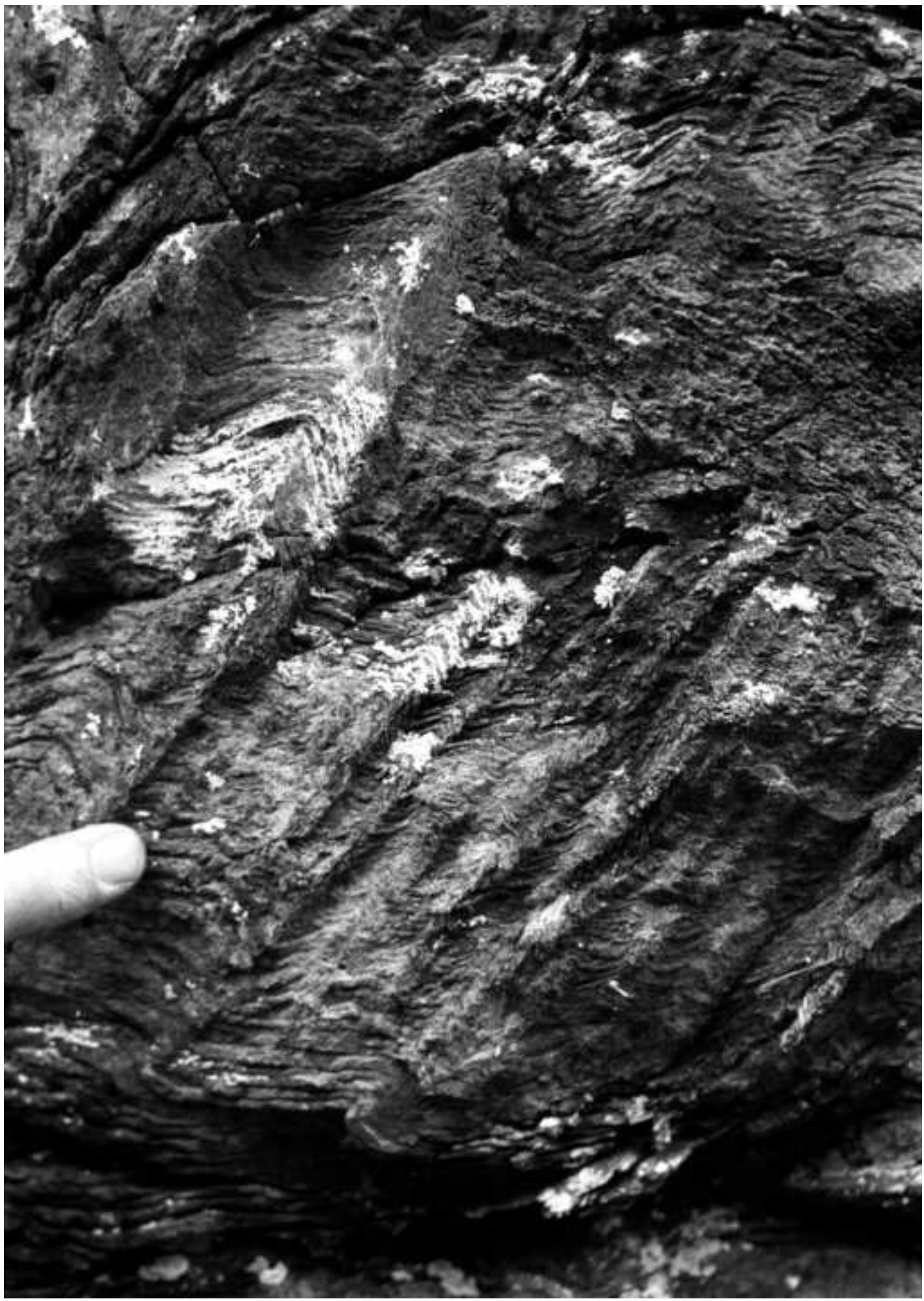


Click here to download high resolution image

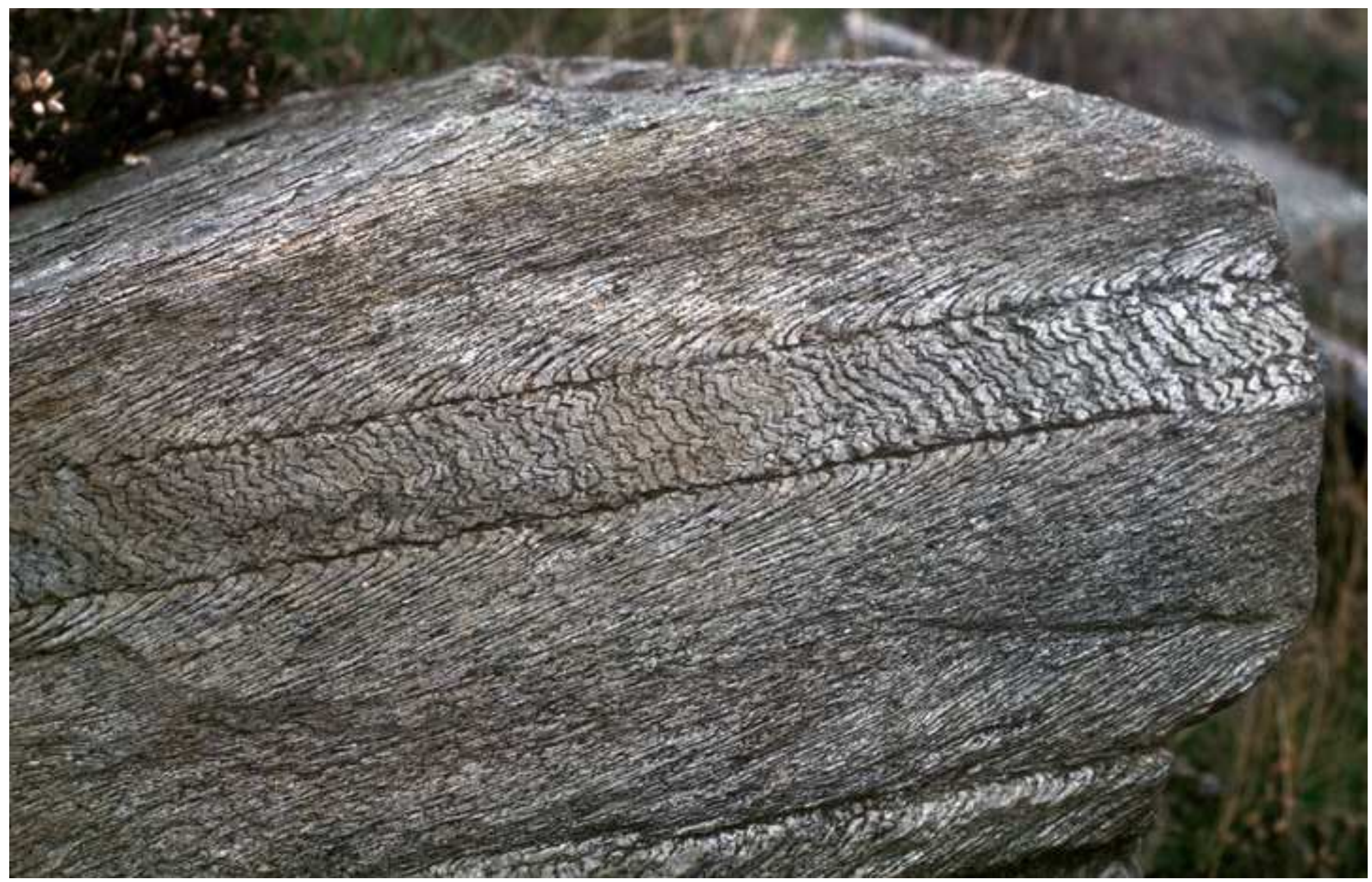



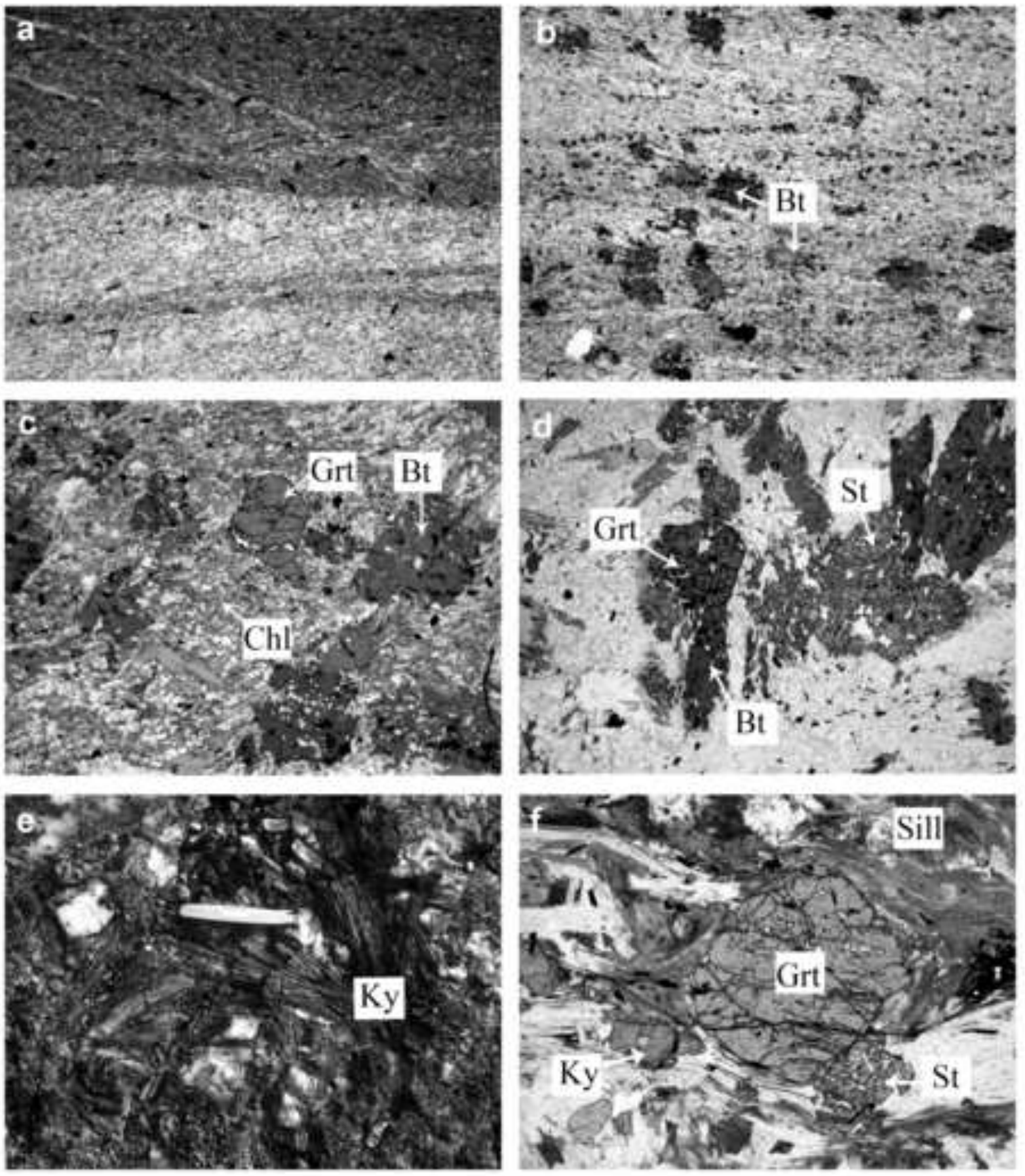
Click here to download high resolution image

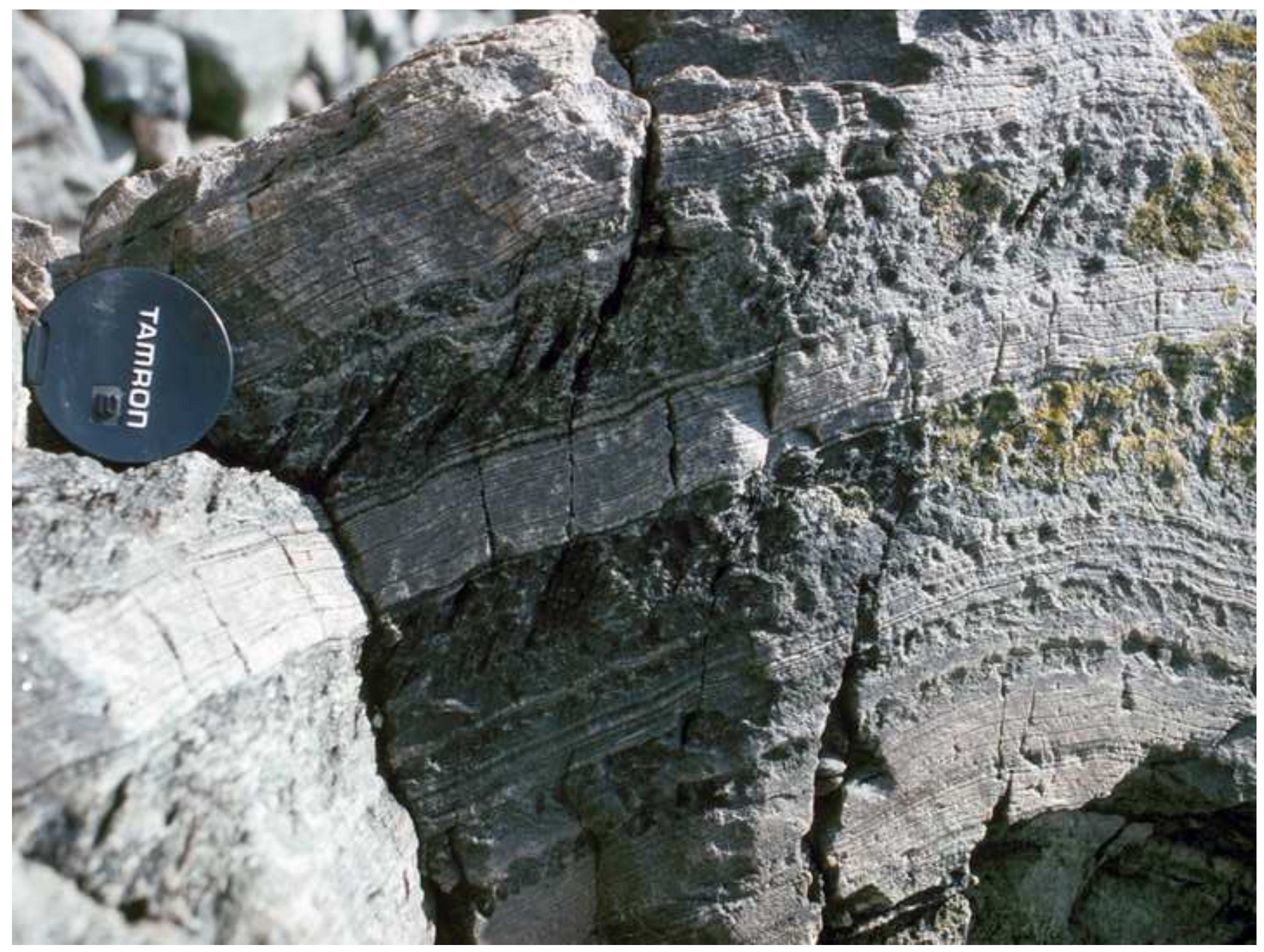


Click here to download high resolution image

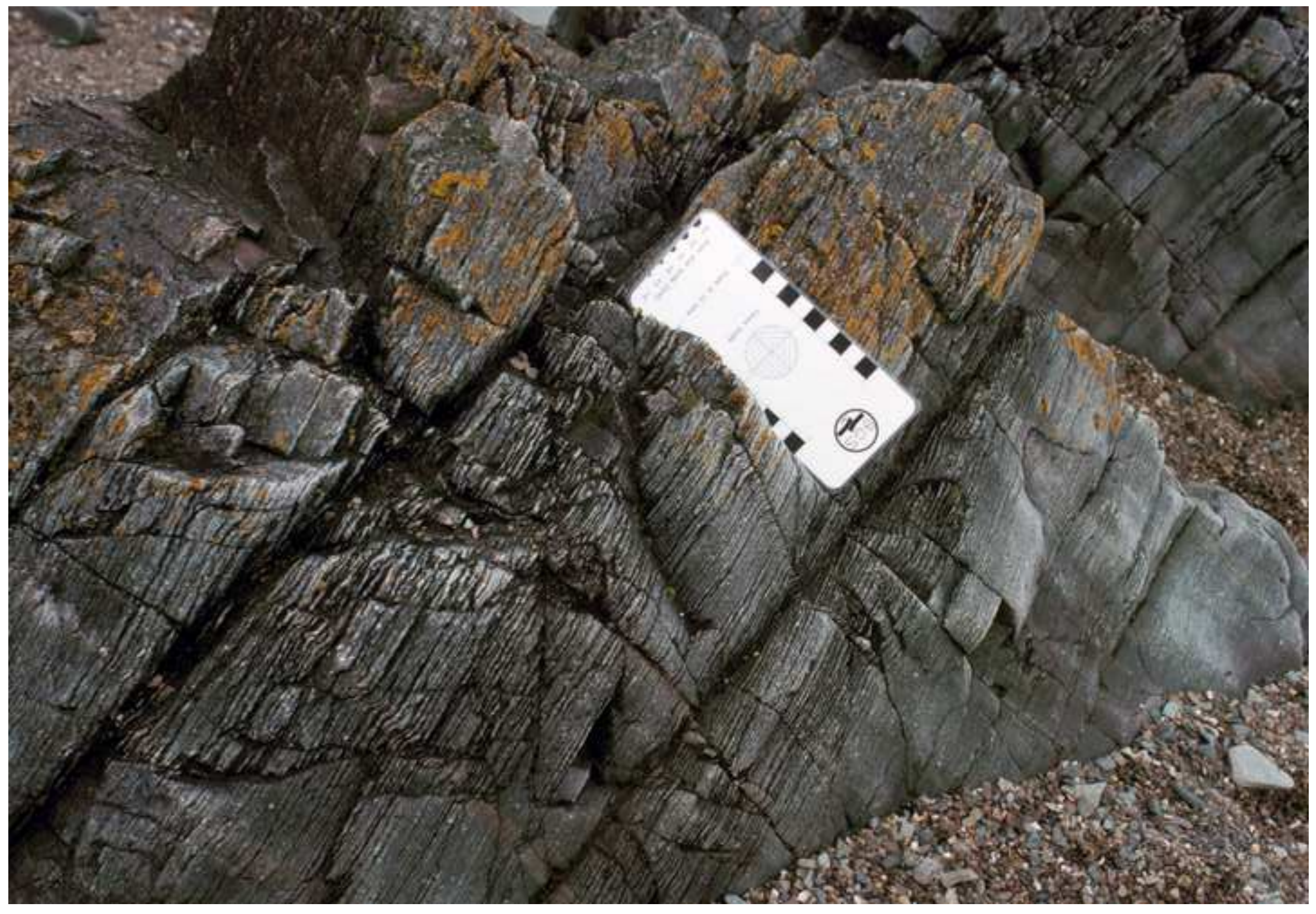




\section{Click here to download high resolution image}

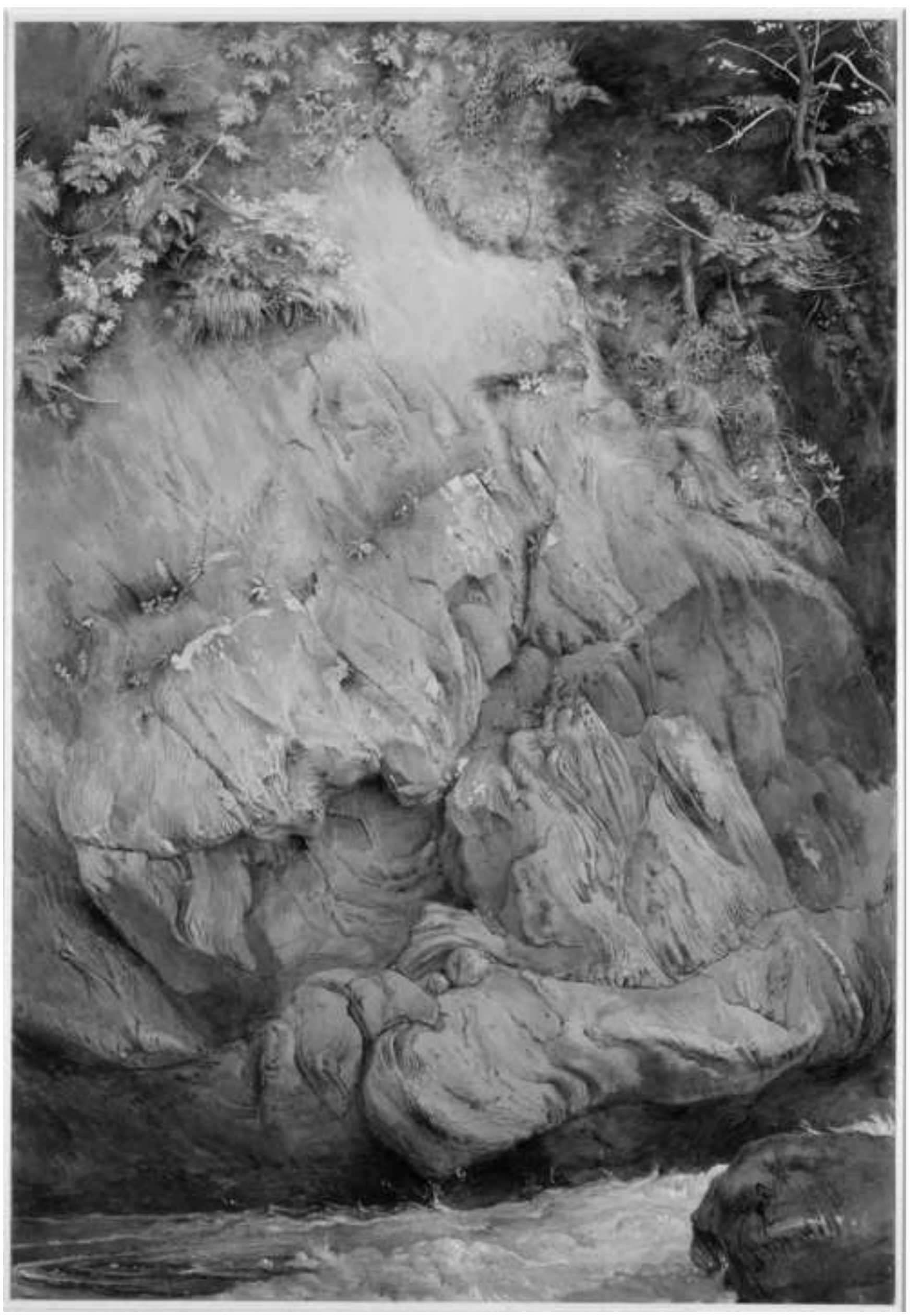

Figure 4.3 B\&W 


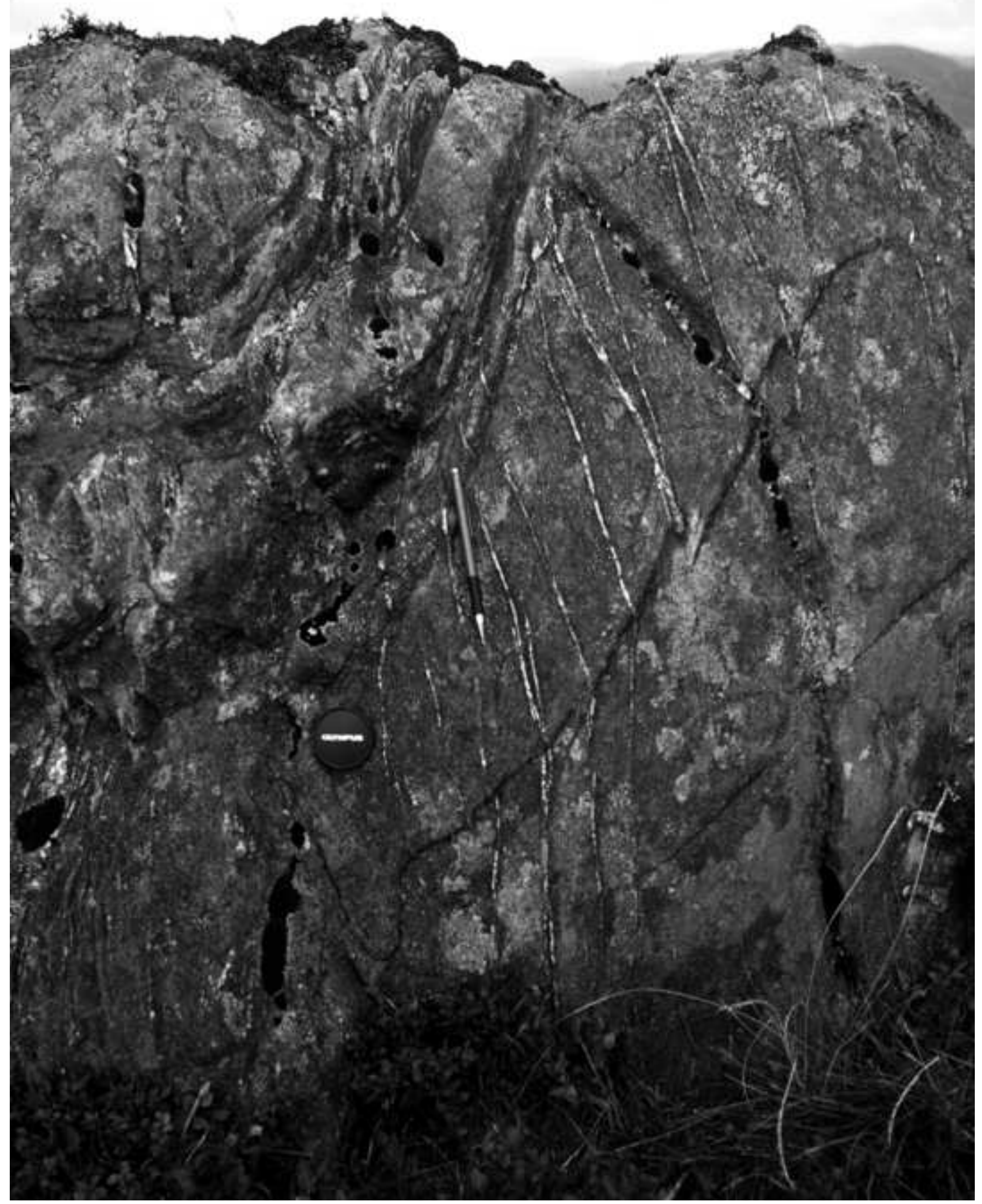


Figure 4.17 B\&W

Click here to download high resolution image

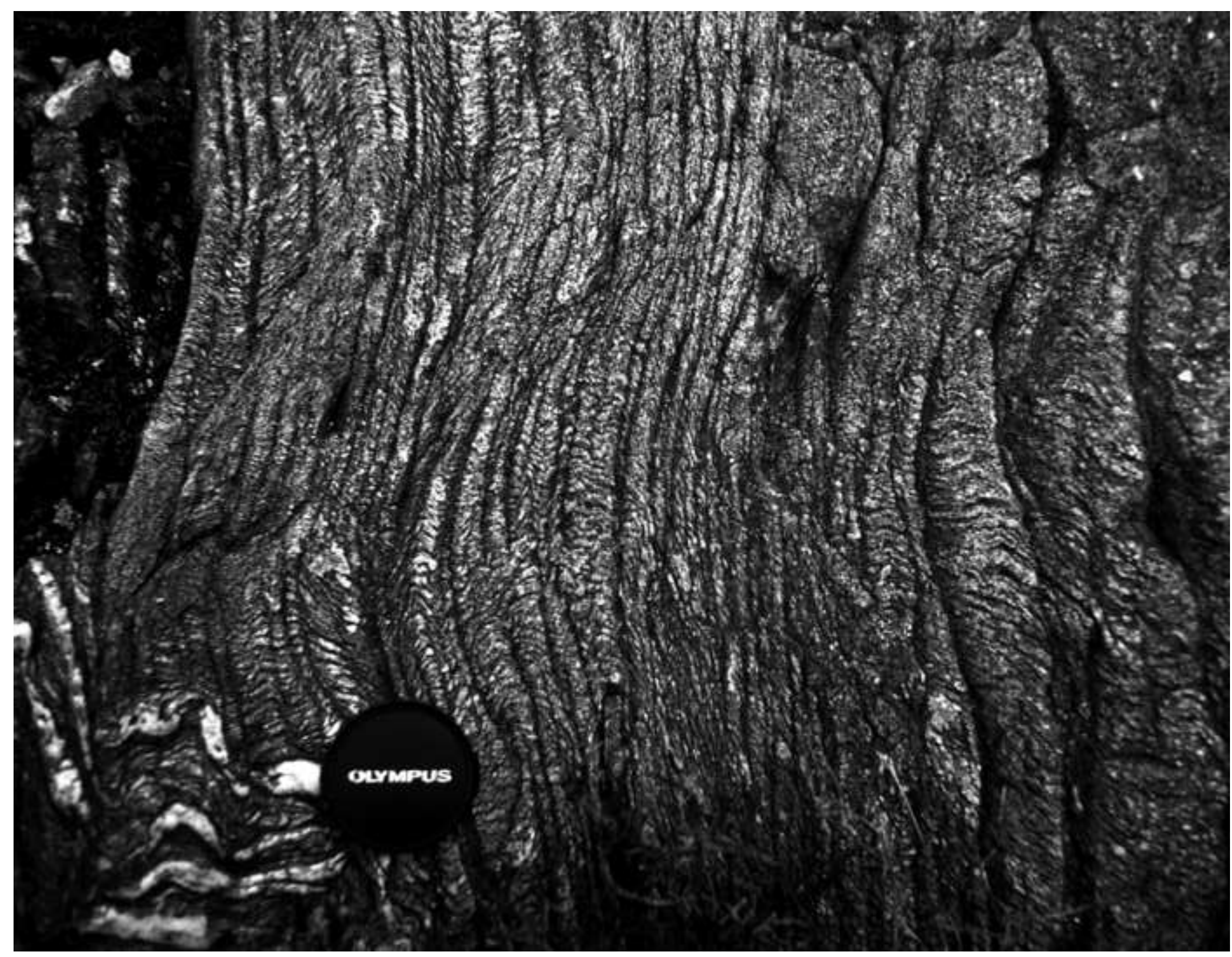




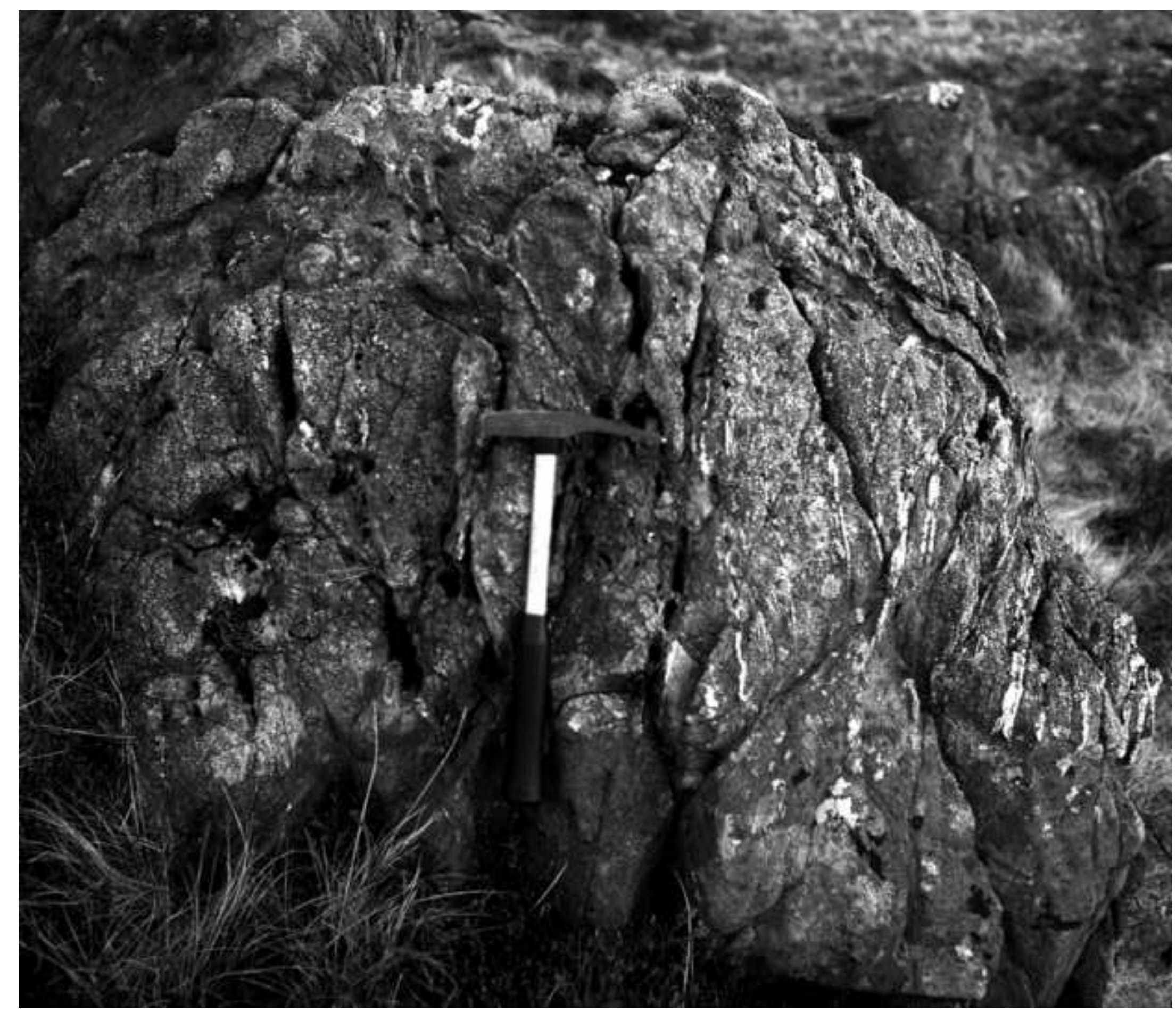




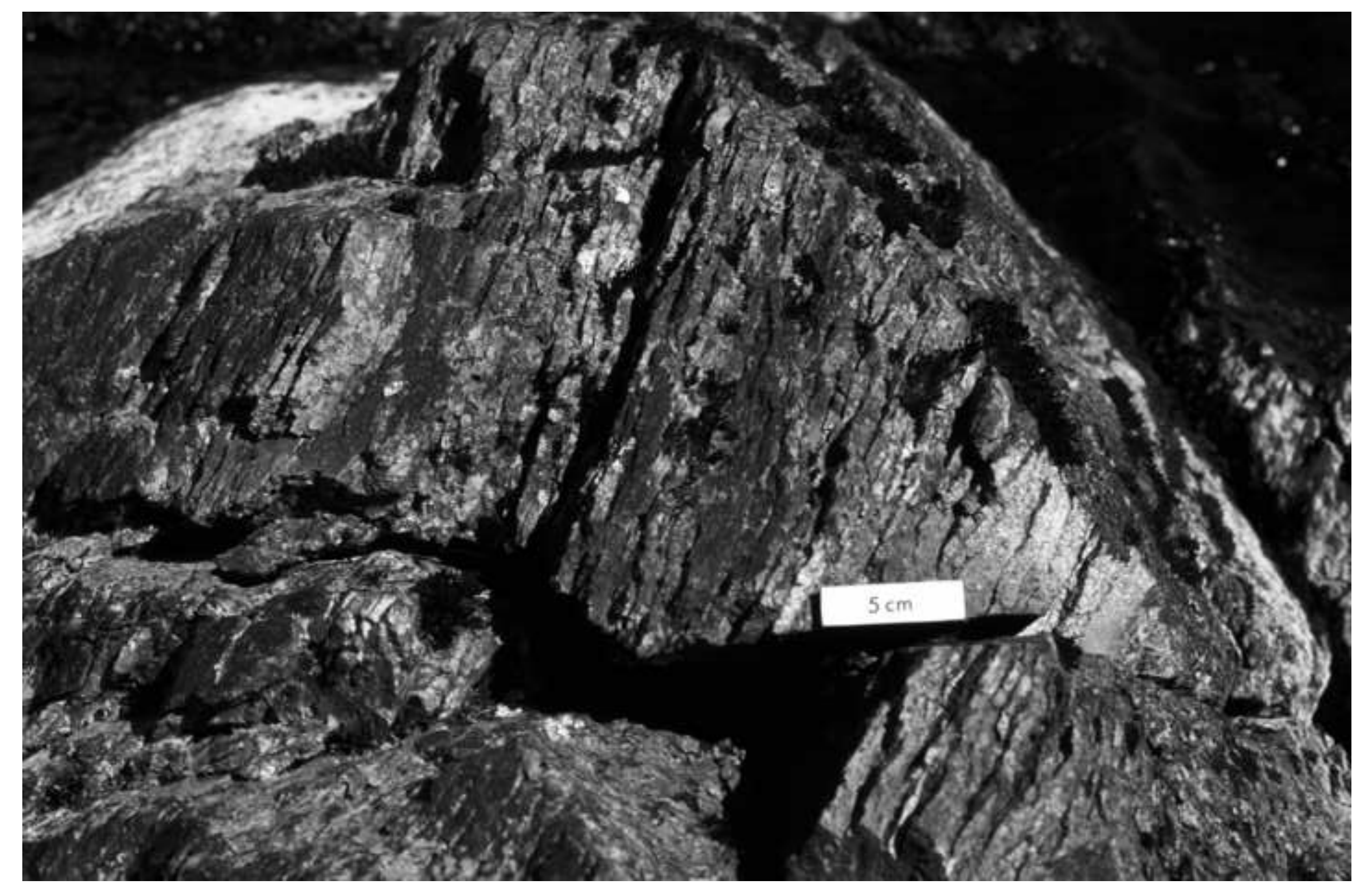

(1)

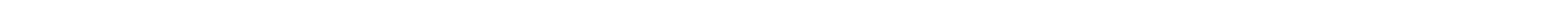


Figure 4.26b B\&W

Click here to download high resolution image

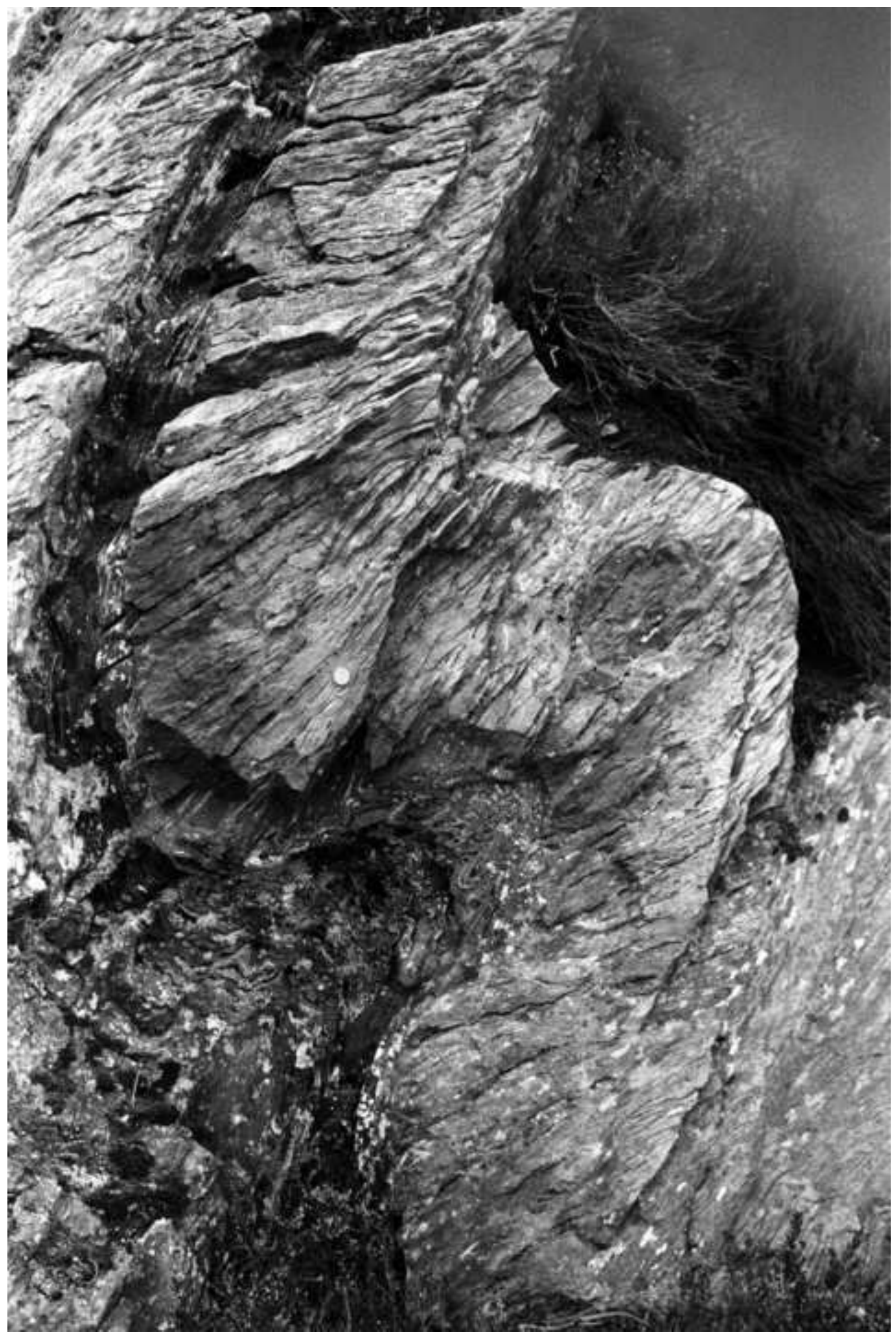


Click here to download high resolution image

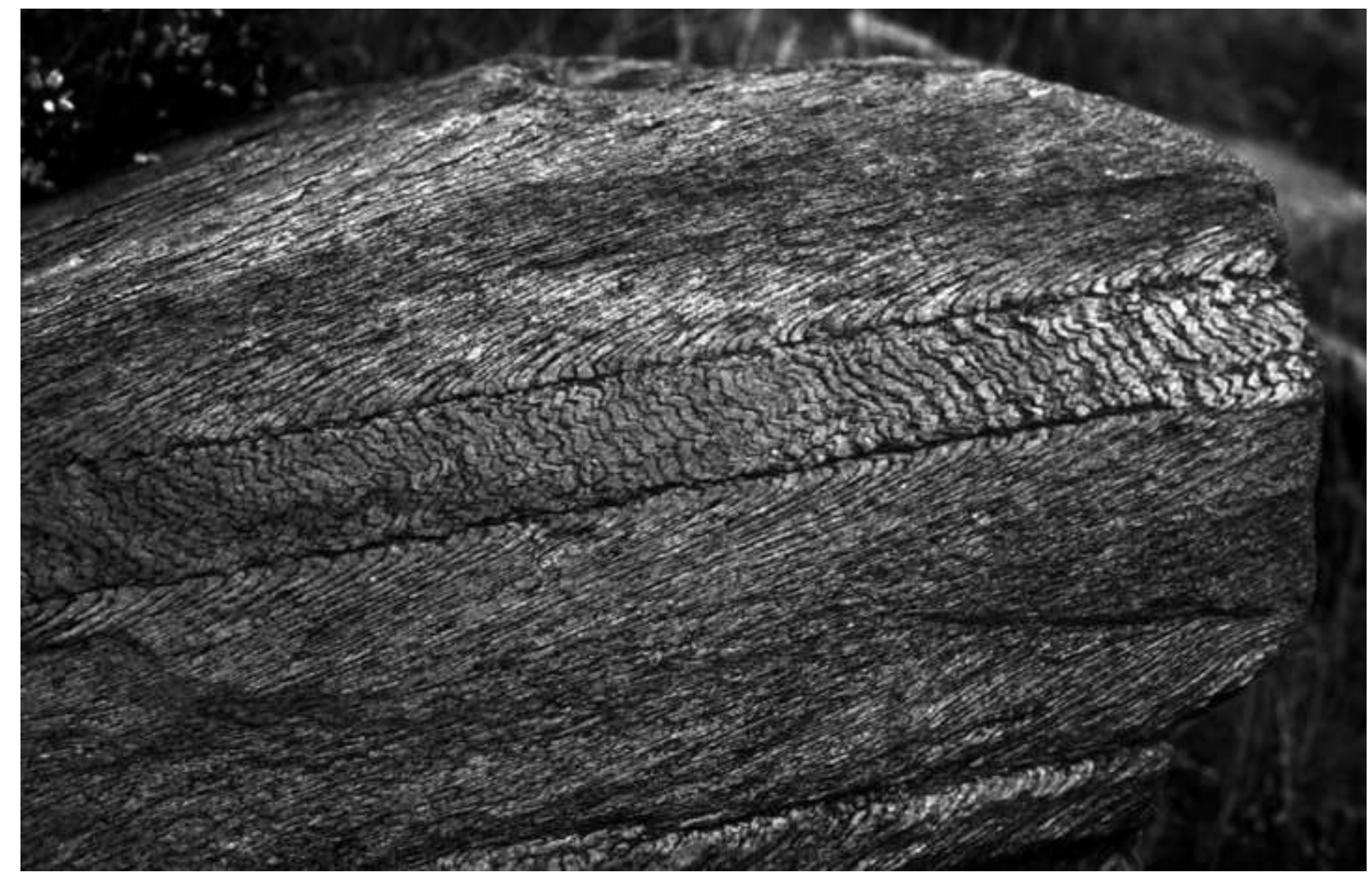


Click here to download high resolution image

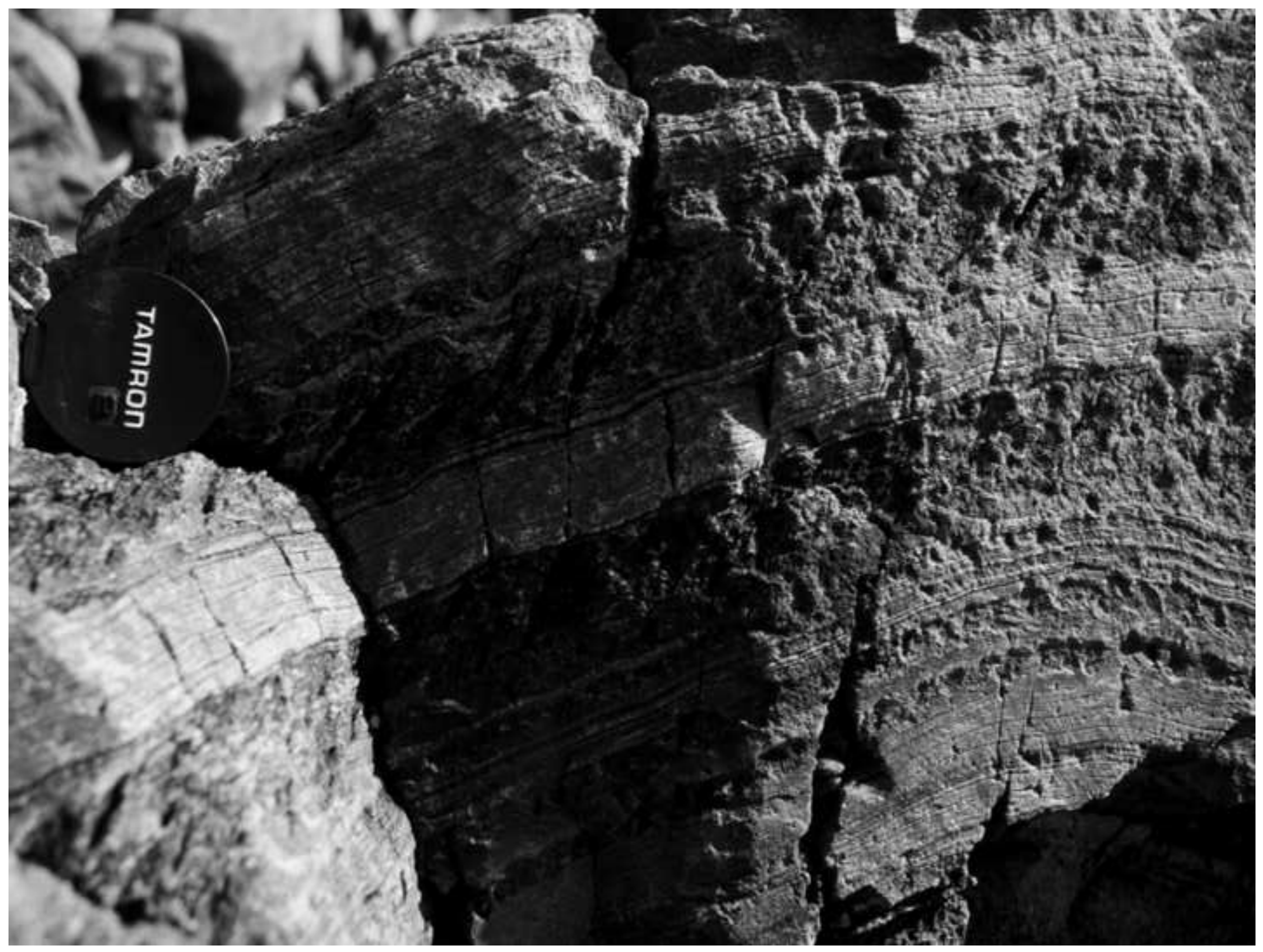




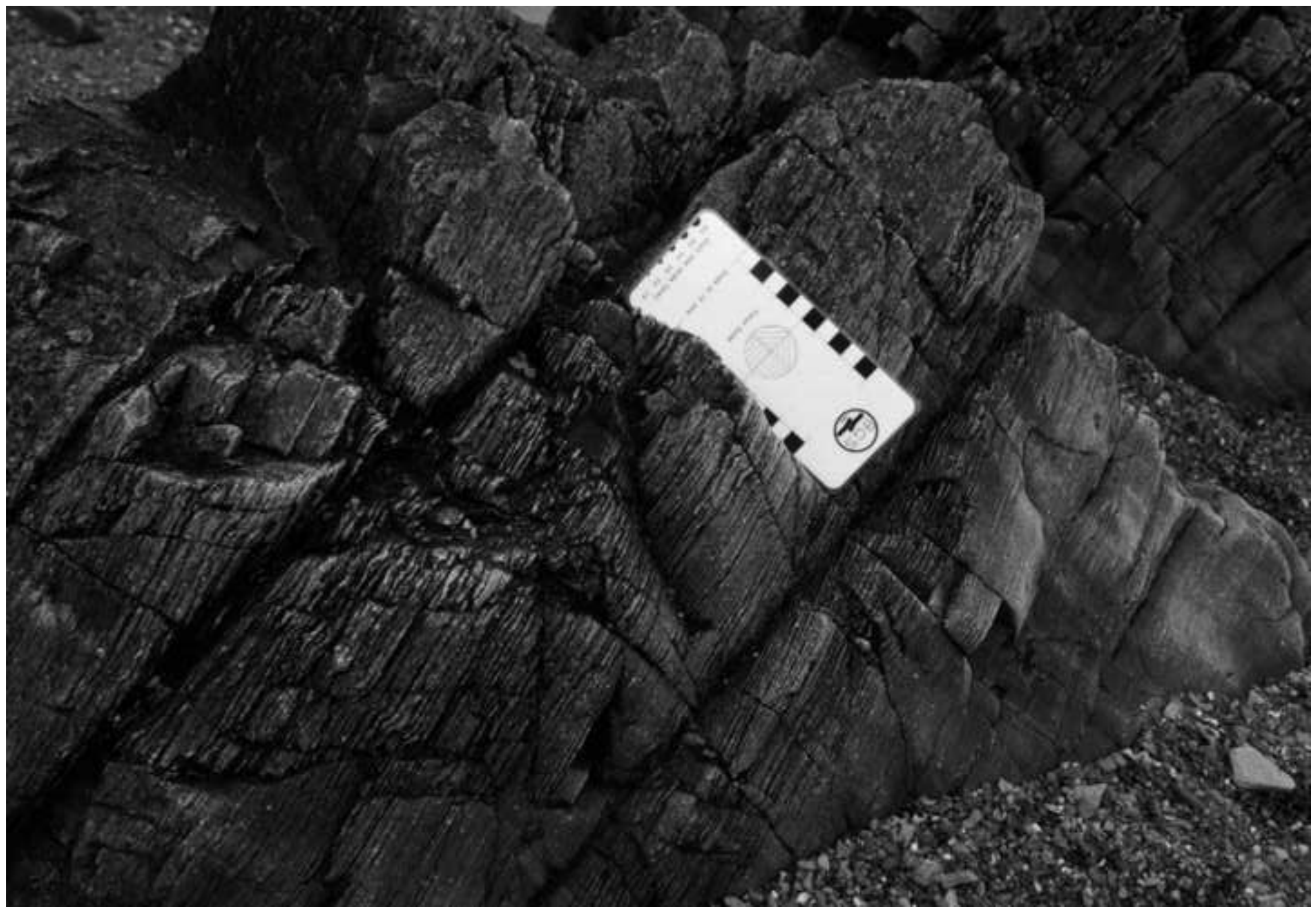

